\title{
GREEK ELEMENTS \\ IN ARABIC \\ LINGUISTIC THINKING
}

\section{PROEFSCHRIFT}

TER VERKRIJGING VAN DE GRAAD VAN DOCTOR IN DE LETTEREN AAN DE KATHOLIEKE UNIVERSITEIT TE NIJMEGEN, OP GEZAG VAN DE RECTOR MAGNIFICUS PROF. DR. A.J.H. VENDRIK

VOLGENS BESLUIT VAN HET COLLEGE VAN DEKANEN

IN HET OPENBAAR TE VERDEDIGEN OP 13 JANUARI 1977 TE 16.00 UUR

DOOR

CORNELIS HENRICUS MARIA VERSTEEGH

geboren op 17 oktober 1947 te Arnhem

LEIDEN

E. J. BRILL

1977 

GREEK ELEMENTS

IN ARABIC

LINGUISTIC THINKING 


\section{GREEK ELEMENTS IN ARABIC LINGUISTIC THINKING}

\section{PROEFSCHRIFT}

TER VERKRIJGING VAN DE GRAAD VAN DOCTOR IN DE LETTEREN AAN DE KATHOLIEKE UNIVERSITEIT TE NIJMEGEN, OP GEZAG VAN DE RECTOR MAGNIFICUS PROF DR A J H VENDRIK VOLGENS BESLUIT VAN HET COLLEGE VAN DEKANEN IN HET OPENBAAR TE VERDEDIGEN OP 13 JANUARI 1977 TE 1600 UUR

DOOR

\section{CORNELIS HENRICUS MARIA VERSTEEGH}

geboren op 17 oktober 1947 te Arnhem

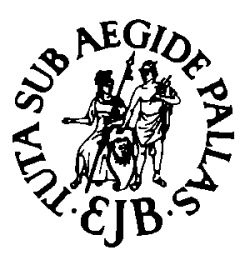

LEIDEN

E. J. BRILL 
The publication of this book was made possible through a grant from the Netherlands organization for the Advancement of Pure Research (Z.W.O.)

Promotor : Prof. Dr. S. WILD

Co-promotor : Prof. Dr. M. van Straaten os A 


\section{TABLE OF CONTENTS}

Preface .

I. The first contact with Greek grammar . 1

$\begin{array}{ll}\text { II. Articulated sound and its meaning } & 19\end{array}$

III. The theory of grammatical categories . . . 38

A. The parts of speech and Sibawaihi's division $\quad 38$

B. The noun . 54

C. The verb . $\quad$. $\quad$. . . $\quad 70$

IV. The usül an-nahww and Greek empiricist medicine . 90

$\begin{array}{ll}\text { V. The period of the two schools } & 107\end{array}$

VI. The influence of Greek logic . 113

$\begin{array}{ll}\text { VII. The use of logic in grammar } & 128\end{array}$

$\begin{array}{ll}\text { VIII. The Mu'tazila } & 149\end{array}$

IX. The origin of speech _ . . . . . 162

X. The Stoic component in the theory of meaning 178

Diagram of the most important Arabic grammarians 192

List of abbreviated titles . $\quad 196$

Arabic, Greek, Hebrew, Latin authors quoted _ . . . . 205

Originals of the Arabic and Greek texts quoted in English translation

Indexes

Personal names . 230

Arabic terms $\quad 234$

Greek terms . . . $\quad 238$

Latin terms . . . . 242

Hebrew and Syriac terms . 243 
- that most irksome and difficult part of literature, with so much labour of the memory, and with so little assistance of the understanding ' 1

There are two ways of studying the historiography of linguistics: either you stress the continuity of the history of linguistics and bring out the essential similarities between geographically and chronologically diverse approaches to the study of speech, or you treat every approach as an individual and unique phenomenon without bothering with parallels. The former method was used by Chomsky in his 'Cartesian linguistics', and it brought him a lot of criticism from both historians and linguists. ${ }^{2}$ The latter, more or less philological, form of the historiography of linguistics seemed to have gone out of use, but there appears to be a revival in recent times: congresses, collections of studies, a special journal. ${ }^{3}$ Within this new wave of interest in the history of linguistics Arabic linguistics does not seem to have received its full share, neither from general linguists, nor from Arabists $;^{4}$ it is rather frustrating to read that 'curiously enough, the Arabs seem to have contributed nothing to the study of language comparable to the additions and improvements they made in mathe-

1 Robert Lowth, Introduction to English grammar, London, 1762; ed. Alston, 1967, no 18 , preface.

${ }^{2}$ Chomsky, 1966. From the many reviews and discussions pro or contra we cite : Aarsleff, 1970, especially pp. 571-2; id., 1974, Koerner, 1976; Miel, 1969; reviews in. Linguistics, 49, 1969, 74-91 (Brekle; the same review in: Linguistische Berichte, 1, 1969, 52-66); Archiv Orientálni, 36, 1968, 484-5 (Zgusta); International Journal of American Linguistıcs, 34, 1968, 290-303 (Zimmer); Phılosophıcal Revıew, 77, 1968, 229-35 (Harman); Language, 45, 1969, 343-64 (Lakoff).

${ }^{3}$ Congresses about the history of linguistics were held in 1964 at Burg Wartenstein be Gloggnitz in Austria, and in 1968 in Chicago; the thirteenth volume of the series 'Current trends in linguistics', edited by H. Aarsleff, R Austerlıtz, D. Hymes, L. Romeo, E. Stankiewicz will be dedicated to the historiography of linguistics; a collection of studies about the history of linguistics with special attention to the relevance of Kuhn's theories for the historiography of linguistics was edited by Hymes, 1974; in his introduction to this collection Hymes announces the appearance of a new joumal, Historiographia Linguistica, under the editorship of E. F. K Koerner (cf. ib pp. 20-1), which is now in its third year; an important collection of origınal articles has been edited by Partet, 1976.

4 The only comprehensive history of Arabıc grammar is still G Flügel's Die grammatischen Schulen der Araber, the first and only part of which was published in Leipzig, 1862 
matics, astronomy, physics, medicine, and natural history'. ${ }^{5}$ The history of classical grammar is treated somewhat better, although not much. ${ }^{6}$

The special problem of the relationship between Greek and Arabic linguistic thinking is almost completely disregarded: reference is made almost solely to the supposed similarities between Aristotelian logic and Arabic grammar. The theory that Aristotle provided the Arabic grammarians with some basic notions concerning speech and the study of speech has been advanced before, especially in the past century, and it met then as now with the seemingly unrefutable objection that the origin of Arabic linguistics lies before the introduction of Greek writing into the Arabic world. Our thesis is that Greek logic (not just Peripatetic, but Stoic logic as well) did play a considerable role in the history of Arabic linguistic thinking, but only at a later time, during the 9 th $/ 3$ rd and the 10 th/4th centuries, when the center of Arabic linguistics had been transferred to Baghdad. The beginnings of Arabic grammar, on the other hand, are characterized by the direct, personal contact with living Greek education and grammar in the recently conquered Hellenistic countries. ${ }^{\text {? }}$

We hold that in this early period many elements of linguistic theory, especially in the field of paradigms and terminology, were borrowed from Greek by those Arabic scholars who started to describe their own language scientifically. ${ }^{8}$ When we use here the word 'borrowing' (or sometimes calque) we use the technical apparatus of the study of 'christianisms' in Greek and Latin. The study of borrowings has reached such a level in this field that it may have a special methodological relevance for the study of borrowings from Greek into Arabic. ${ }^{9}$ The chapters of our dissertation are arranged according to a rough chronology. The first four chapters discuss Greek elements in the first

s J.C Greene, in Hymes, 1974, 494

- A brief, but useful state of the art in Scaglione, 1970, 11-43

7 General studies about the history of the relevant period Byzantıne history: Ostrogorsky, 1963 3 , Vassliev, 1935-68; id., 1970², Arabıc history: Spuler, 1952-3; Gabrieli, 1965; Brockelmann, $1974^{2}$ : Hittı, $1968^{9}$ About the problem of the contacts between the Byzantine empire and the Arabic East: Kraemer, 1959.

a We use the word 'scientifically' in order to distınguish between the activities of Sibawaihı and hıs immediate predecessors on the one hand, and the obscure origıns of Arabic grammar at a pre-scientific stage on the other; cf. the discussion in chapter 1 .

9 Cf. Mohrmann, $1961^{2}$, especıally the artıcles 'Quelques traits charactéristıques du latın des Chrétiens' (21-50). 'L'étude de la latınıté chrétıenne État de la question, méthodes, résultats' (83-102), 'Le problème du vocabulaire chrétien Expériences d'évangélisatıon paléo-chrétıennes et modernes' (113-22); about calques. ib. 44 sqq., 280 sqq. 
stages of Arabic grammar. Chapter I gives a brief sketch of the historical context of the process of Greek influence on Arabic grammar. The next three chapters deal with the various Greek elements we have found within this first stage: in the field of sound, articulation, and meaning (chapter II); in the theory of the parts of speech, declension, verbal tenses, and so on (chapter III); in the methodology of grammar, i.e., in the system of norms of linguistic method (chapter IV). Chapter $V$ deals with the position of the two schools of Bașra and Kūfa in the history of Arabic linguistics.

Chapter VI and VII are concerned with a iater stage, when Greek writings had begun to play a more indirect role, through their translations into Arabic: their influence was felt not only in grammar, but also in logic and philosophy. In chapter VI we sketch the historical context; then we examine in detail the logical arguments used in grammatical literature, in so far as they can be traced back to Greek influence (chapter VII). Chapter VIII discusses the role of the Mu'tazila, an important sect in the history of Muslim theology. The Mu'tazilites are characterized by their liberal use of Greek dialectic methods in defense of their theological dogmas, the most important of which was a rigorous monotheism. They should not be regarded as a group of free-thinking liberals, on the contrary, when their point of view gained official support under the 'Abbāsid caliphs from $833 / 218$ till $850 / 236$, they took a very intolerant stance on contrary opinions. ${ }^{10}$ They are interesting for our purpose mainly because of their use of logical methods, and their particular views on speech and thinking. In chapter IX we discuss the theories concerning the origin of speech, a comparatively recent topic in Arabic linguistics. In chapter $\mathrm{X}$, we examine the role of Stoic linguistics, especially in the theory of meaning.

Originally, the essential part of this dissertation was a translation of the work of a tenth century grammarian of Baghdad, namely the İăh fi ilal an-nahww (Explanation of grammatical norms) by Abū 'l-Qãsim 'Abd ar-Raḥmān ibn Isḥāq az-Zağğāği. ${ }^{11}$ We have abandoned this plan, but its traces are still discernible throughout our dissertation in the form of the many quotations from the Idăh, which turned out to be a very useful work on Arabic linguistics, not because of

${ }^{10} \mathrm{Cr}$ about this period. Patton, 1897; Gabriel,, 1929; about the Mutazila: Nader, 1956

1 Data about this Arabic grammarian in the introduction to the edition of the Ị̇āh by M Mubārak, Caıro, 1959 
the originality of the author, but because of his personal acquaintance with most of the important Baghdadian grammarians. ${ }^{12}$ Often we have not been able to trace a particular point of linguistic doctrine back to its first occurence; in these cases we have contented ourselves with quotations from the $\bar{I} d \bar{q} h$, or we have had to rely on even later authority, more than once as late as Suyūtị, a fifteenth century compiler, who wrote his Muzhir by quoting extensively from all sorts of grammatical and lexicographical writings. The necessity of combining the two disciplines of Classical and Arabic studies caused some rather long discussions: we tried to make the context comprehensible for both disciplines, but we fully understand that the digressions are often tediously self-evident to the specialist in either field.

In translating Arabic and Greek terminology we have generally used current English equivalents, not as a matter of principle, but in order to make the discussion somewhat more readable; a few exceptions to this custom are mentioned in the following note. ${ }^{13}$ Details about the abbreviations used in references and quotations are given in the bibliography at the end of the book. ${ }^{14}$

In my view it is difficult, given the present condition of our sources, to determine beyond any reasonable doubt the extent of Greek influence in Arabic grammar, as far as the scientific beginnings of Arabic grammar are concerned-for later periods we have the translations of the Corpus Aristotelicum as a textual basis at our disposal. At most

12 As he himself tells us, Zağğ Iḍ 78-80

13 One should keep in mind that the Englısh terms are not synonymous with the Arabic terms, e g 'declension' translates iräb; 'nomınatıve' represents raf In a few cases we have used the Arabic term, when no English term was available, e.g alif, masdar (for obvious reasons the English 'infinitive' could not be used). In other cases a Latın term was used, e.g. 'nomınatum' (for musammä). In accordance with Arabic grammatical theories the concept of 'declension' has sometimes been applied to the verbs, so that verbs may be said to be declinable and to have cases. For gazm we have chosen 'jussıve' 'Inflection' translates sarf or tașrif. One should always keep in mind that ism and $f i l$ have two meanings: 'noun' / 'name' and 'verb' / 'action', respectively. The third part of speech, harf, is the '(meaninglul) particle', harf as against haraka (vowel) is sometimes translated as 'consonant', but in other cases we preferred to translate this term with 'letter'. Added words in quotations are between brackets; explanations are introduced by 'sc.'; the other abbreviations will be obvious. Greek proper names are transliterated, except 'Plato' and 'Aristotle'; Latin proper names are used in their Latin form. The system of transliteration of Arabic is almost identical to that of Arabica (exceptions: al instead of $a y$; the assimilation of the hurüf samsiyya is indicated, as well as the hamzat al-wasl)

14 In quoting from the Stoicorum Veterum Fragmenta we have used two systems for ease of reference either three ligures, referring to volume, page, line; or two figures, referring to volume and fragment. 
we can show the probability of a connection between Arabic and Greek linguistic thinkıng I am fully aware of the fact that details of my explanation of the phenomena and terminology of Arabic grammar, which form the basis of my argumentation, are perhaps consistent with alternative explanations I have, however, tried to define the historical context within which I place my explanations, and this, I believe, justıfies my bringing together these arguments and regardıng them as sufficient support for my case, even though I am also aware of the high risk of a vicious circle starting from the assumption that there was contact between Greek and Arabic grammar, I was, of course, continuously tempted to regard something as proof precisely because of my original thesis I have taken this line of research, because up till now there has been hardly any serıous attempt to put together materials from later Greek grammar and Arabic linguistic thinkıng I have tried to collect these materials and to compare them, even if the comparison seemed sometımes far-fetched or tivial Perhaps these materials will be useful, even if the original thesis should have to be modıfied

Historiography of linguistics is a dangerous field of research, in which anachronıstic thınkıng is very tempting I have, however, refrained from any commentary on similarities and parallels between Arabic linguistıc theory and contemporary linguistics, and only tried to present the facts as I saw them, without subscribing either to a relativist or an evolutionist point of view The historiography of linguistics has not yet begun, or rather, has not yet proceeded beyond a first exploration of the facts What we need now is a methodology, and a critical reflection on the historical growth of linguistics We may expect that in this sense the historiography of linguistics will contribute, not so much to the solution of the problems of our discipline, as to the formulation of the relevant questions

N B The abbreviations $A$ and $G$ refer to the original texts included on pp $209 \mathrm{ff}$ The former abbreviation indicates an Arabic text, the latter a Greek one 


\section{THE FIRST CONTACT WITH GREEK GRAMMAR}

'This science is called in Greek garmäriqi, and in Arabic nahu' 1

It is nowadays generally agreed that learned Arabs in a good many branches of science were influenced by their Greek predecessors, but a restriction is made for the so-called pure Arabic sciences, such as the science of tradition and linguistics. This view is partly based on the Arabic tradition: a good example of the traditional account of the history of linguistics is the one given by Ibn Haldūn, who explains how the science of linguistics was born from the necessity to prevent the corruption of the Arabic language. ${ }^{2}$ Our intention is to show that a claim for Greek influence may be made for Arabic linguistics as well, and that, as a matter of fact, this influence followed the same course in linguistics as, for instance, in the field of logic and philosophy. This means that we have to distinguish between a direct and an indirect way of transmission, the first one of which was earlier than the second. In the first place we must direct our attention to the origin of Arabic linguistics in order to demonstrate which elements in this phase were the result of direct contact between Arabic grammarians and Hellenistic culture in many of the conquered territories; in the second, we must show how later developments may be explained by the growing influence of Arabic translations of the works of Aristotle and his commentators.

All over the eastern Hellenistic world, in every place of any cultural standing, the Greek language was being used, at first as a sort of lingua franca for the cultured people - the lower strata of the community continued to speak Aramaic dialects (e.g. Syriac) or Coptic-, ${ }^{3}$ but soon there arose independent cultural centres, the importance of

1 Hwār Maf 42, 13 [Al]

2 b Hald Muq, 546-7, cf also Fuck, $1955^{2}, 6$ sqq, We1B, 1910, 349-50

${ }^{3} \mathrm{Cr}$ e g Festugière, 1959, 291 sqq several monks did not even understand Greek (4th century) For the stuation in Egypt we refer to note 16 below About the political situation in the Byzantine empire and the hostility towards the central government in the Eastern provinces Stratos, 1968 
which grew as the power of Greece itself declined. Alexandria in Egypt and Antioch in Syria were among the most important ones, ${ }^{4}$ but in a later period the number of cities with their own universities and educational systems increased, partly as a result of the competition between the various Christian sects, for instance in the Nestorian East Edessa and Nisibis, ${ }^{5}$ and later, in the Persian empire, the famous school of Gundi-Sãpūr near Kūfa, a refuge for scholars of other universities who had had to flee because of their heretical opinions. The Persian emperor Hosroes Anuširvān (d. 587 A.D.) gave shelter at his court to those philosophers who were without a job after Justinian had closed the Athenian academy (in 529 A.D.), among them even the great Simplikios! ${ }^{6}$ In these centres of culture and science, Greek philosophy was studied and Greek writings were translated into Syriac and Persian. ${ }^{7}$ It was in this region, near Gundi-Sāpūr, and not in the neighbourhood of the Umayyad court at Damascus, that the first signs of Greek influence appeared. The first juridical speculations, ${ }^{\mathbf{8}}$ and the nature of the first Mutazilite debates about the creation of the Qur'an, the problem of free will, and the doctrine concerning the attributes of Allahh: ${ }^{9}$ all these issues bear witness to the contact between the two cultures in various fields, before the 'official' translation of Greek writings. Muslims and Christians were forced to live together, and so, inevitably, Greek knowledge was communicated to the East before the indirect transmission began. ${ }^{10}$ We will try to show that this first contact played a considerable role in the field of logic and linguistics.

${ }^{4}$ On Alexandria. Meyerhof, 1930; Schemmel, 1909; Parsons, 1952; Meyerhof, 1933; Bell, 1946 On Antioch D Downey, 1966².

${ }^{5}$ On the Eastern church and its influence on Islam Bell, 1926. About Edessa. Duval, 1892, Segal, 1970, Hayes, 1930, Furlanı, 1937 About Nısıbis: Vööbus, 1962, Hermann, 1926.

6 Agathias, II, 30

7 There is an interesting statement in the chronography of Abū 'Isā ıbn al-Munag̉g ım (3rd/10th century. Sezgin, 1967, 1, 322) that under the reign of the Sassanid king Sāpūr (241-272 A D) the Persians conquered Greek and Roman provınces, such as Upper Mesopotamı, Syrı, Egypt, Constantınople (sic!), and that they took 'the books of the phılosophers' Kıng S̄āpūr even receıved, accordıng to thıs account, Greek scientıfic books from the Roman emperor (Islamic phılosophy, 1972, 437-66, especially p. 454), cf Peters, 1968, 46

On traces of Greek logic and Roman law in early Muslım legal thought van Ess, 1970, 33 and $n$ 59, Schacht, 1950 . Cr below, chapter IV, note 53.

"On the polemic of Byzantine theologians aganst Islam. Khoury, 1969² Krumbacher, $1897^{2}, 49-51$ The influence of the Church fathers on Islamic theological thinkıng is emphasized by Seale, 1964, of also van Ess' remarks, 1966, 18-20

10 de Lacy O'Leary, 1949. 142; also pp 68, 143, Daif, 1968, 21. 
The Hellenistic universities not only gave courses in Greek philosophy, but also in the Greek language, which as the most important instrument and medium of teaching, constituted a compulsory subject for every student of philosophy. ${ }^{11}$ For a long time the language of education remained Greek, but in the East Syriac gradually took its place. At the end of the 4th century a Spanish nun Egeria, who made a pelgrimage to the Holy Land, observed that only part of the population spoke both Greek and Syriac, the rest spoke only one of the two languages. ${ }^{12}$ Bilingualism was probably restricted to the upper classes, but sometimes even a bishop only began to study Greek at an advanced age. ${ }^{13}$ Greek exercised an enormous influence upon Syriac -many loanwords, the system of the vowel-signs, ${ }^{14}$ even the literary style-, but Syriac remained in use as the language of the lower classes. After the invasion of the Arabs, it became more important as the intermediary language between Greek and Arabic: translations were made first from Greek into Syriac, and then from Syriac into Arabic. This shows that the study of Greek did not disappear; on the contrary, it became more important than ever to have at one's disposal trained translators who could provide the students with translations of Greek philosophical writings. ${ }^{15}$ In Egypt, although even among the clergy many people, even bishops, did not understand Greek, ${ }^{16}$ this language remained in use as the language of educated

${ }^{11}$ Georr, 1948, 10

12 Itınerarıum Aptheriae (Egerıae), ed. H Pétré. Parıs, 1948 (Sources Chrétıennes): $\therefore$ and in that province (sc Syria) only part of the populations knows both Greek and Syriac; others only Greek, and still others only Syriac, the bishop, therefore, always speaks Greek, never Syriac, even if he knows it. There is always a priest nearby, who translates what the bishop says in Greek into Syriac, so that everyone may hear the argument'. (et quoniam in ea provincia pars popult et graece et sirste novit, pars eltam aha per se graece, aliqua etham pars tantum siriste, itaque quoniam episcopus, hicet siriste novert, tamen semper graece loquitur, et numquam sirıste utaque ergo stat semper presbyter, qu, episcopo graece dicente. siriste interpretatur, ut omnes audiant, quae exponunur) (cap. 47, pp. 261-2)

${ }^{3} S$ Ephraemi Syrı Rabbulae Epıscopı Edessenı . opera selecta, ed J. Overbeck. Oxford, 1866, 160. On Greek Hellenism in the Eastern provinces. Liebermann, $1960^{2}$, Peeters, 1950 .

14 Cr Segal, 1953 (Jacob of Edessa's innovatıons: pp 37-47). Greek loanwords in Syriac: Schall, 1960

15 de Lacy O'Leary, 1949, 71-2

${ }^{16} \mathrm{Cr}$ Mitteis/Wilcken, 1912, pp 87-8: during the Byzantıne perıod Coptic gradually penetrated into public life, increasingly few people understood Greek, for instance, the bishop of Hermonthis, Abraham ( $\pm 600 \mathrm{~A} \mathrm{D}$ ), who had to dictate his testament in Coptic In Arabic times the decline of the Greek language may be deduced from the language of the papyrı (ib. p 91), cf. Peeters, 1950, 12-5; 27-32 
people; at the Alexandrian university, medical courses were always given in Greek.

It is significant that Greek materials remained available. Until the reign of the caliph 'Abd al-Malik (685/66-705/87) Greek remained the language of the administration and the tax-register (diwän) in Damascus. ${ }^{17}$ As late as the 10th/4th century we find the historian Hamza al-Ișfāhānī (d. 961/350) using directly Greek historical materials concerning the Byzantine emperors with the help of a Greek-speaking servant at the court in Ișfahānn. ${ }^{18}$ But, of course, it cannot be denied that Greek rapidly lost its significance as a medium of communication, and that the number of commentaries on the works of Aristotle in Greek decreased.

All the same, there were still people who had studied Greek according to the rules of Greek grammatical tradition, which had been formulated by many authors, beginning with Dionysios Thrax $( \pm 170$ \pm 90 B.C.). At that time, Greek grammatical tradition was actually the only source of grammatical knowledge and study. The Téchnè of Dionysios Thrax was translated at an early date into Syriac, according to the Nestorian tradition by Joseph of Ahwāz, who died before 580 A.D. ${ }^{19}$ Quite fundamental was the work of Jacob of Edessa, who seems to have had a lasting influence on later generations of Syrian grammarians. ${ }^{20}$ Some of these Syrian scholars studied Greek in Alexandria, for instance Sergios of Rešainā (d. 536 A.D.), who wrote a commentary on Aristotle's Categoriae, and a treatise about the parts of speech, ${ }^{21}$ and also the aforementioned Joseph of Ahwāz and Jacob of Edessa. We may, therefore, safely assume that there were translators with a good or reasonable knowledge of the Greek language far into Arabic times. ${ }^{22}$ We may also assume that, unwittingly, the work of these translators and their methods were dominated by Greek linguistic methods, terminology, and categories. Thanks to these translators, a tradition was built up during a period of a few centuries, which served

17 Hittı, 1968', 217, and the anecdotic account with Balādurī, Futūh al-buldān, ed. Riḍwān, Mıṣr, 1959, 196-7: according to Balādurī the naql ad-diwān took place in $700 / 81$; the reason was that a Greek clerk had urinated in an ink-pot!

18 Hamza, Ta'rihh, ed. Gottwaldt, St. Petersburg/Leipzig, 1844-48, (Bagdād, 1961) 70, 11 (min lafz ar-rümi), cf. Wakī's sources, ib. 68, 45, cf. Rosenthal, 1968², 74, n 1, also pp. $91 ; 136-7$

${ }^{19}$ Merx, 1889, 9, Baumstark, 1968², 116-7, 222; Georr, 1948, 5, n. 1

20 Merx, 1889, 34-101; Baumstark, 1968², 248-56; Baumstark/Rücker, 1964, 191-2.

21 On Sergios: Merx, 1889, 6; Baumstark, 1968², 167-9; Georr, 1948, 17 sqq.; of

b. a. Ușaibi'a, 1, 109; 185-9; 204.

22 Peters, 1968, 58. 
as the foundation for the development of Arabic grammar. The story of the first Syriac translations of Greek writings has already been told several times, and we refer to the accounts by Baumstark and others. ${ }^{23}$

Returning to the origins of Arabic linguistics we may summarize them as follows. The different accounts about the first Bașrian grammarian, Abū 'l-Aswad ad-Du'alī (d. 688/69?), emphasize that his priniary intention in 'inventing the art of grammar' was to prevent the corruption of the Arabic language in the mouths of the illiterate and the neophytes, especially, of course, where the text of the Qur'ān was at stake. ${ }^{24}$

A careful study of the sources reveals that, whatever the differences may be in details, they always connect the names of ad-Du'ali and of the fourth caliph 'Alì ibn Abī Taalib (d. 660/40) with the wad" an-nahıw. ${ }^{25}$ We do believe, therefore, that the tradition should be given credit, at least in the main point, namely that grammar was invented in order to save the Qur'ān from corruption. Wild's objection that there are hardly any quotations from the Qur'ân in the oldest lexicographical work, the Kitäh al-ain, and that grammarians were not regarded as particularly religious scholars, is not valid, since it is based on later data. ${ }^{26}$ Moreover, the development of lexicography should not be connected with the development of grammar. It is only natural for the early lexicographers to be interested more in rare words from classical poetry than in the comparatively normal vocabulary of the Qur'ān. The most important argument in favour of ad-Du'ali's activities is the unanimity of the sources about the fact that he was inspired by the necessity to correct the various versions of the Qur'ān and to put a stop to the corruption of speech. As a matter of fact, it is typical of almost every grammar to be used originally as a means to preserve ancient or sacred literature, for instance, the Homeric epic in Greece, the Vedas in India, the sagas in Icelandic literature, and the Confucian texts in China. ${ }^{27}$ The reason is, of course, that as the traditional texts

23 Baumstark, $1968^{2}$ (1922), 1900, Baumstark/Rucker, 1964, 168-204; Duval, $1907^{3}$; Georr, 1948; Klinge, 1939; Huby, 1969 Recent synthesis Rosenthal, 1965

${ }^{24}$ Semaan, 1968, 21 sqq., Daif, 1968, 13 sqq., of the versıon of the story in Zağğ Id. $89,3-12$

25 Mubārak, 1974³, 10-37, gives a detatled analysis of the different accounts, he concludes that the fundamental facts of the story are correctly transmitted by the Arabic sources

26 Wild, 1965, pp. 5-6.

27 On Greece: Steınthal, $1890^{2}, 1,28-9,1891^{2}, 2,71$ sqq. On India' Renou, 1940, 
remained the same, and the colloquial language gradually changed, the danger arose of misunderstanding the (sacred) meaning of the old texts.

The corruption of speech in ad-Du'alī's time consisted mostly in a confusion of the case-endings. This explains why we find Abū l-Aswad mainly concerned with two problems: in the first place punctuation and the creation of a vowel-orthography-which he borrowed from the Syriac script $-;^{28}$ and in the second place the study of the fä il, the maf "ül, and the mudäf ilaihi (or the raf", the nașb, and the garr), i.e., the case-endings. ${ }^{29}$ The 'discovery' of the cases may well have originated with ad-Du'ali ; the terminology was probably interpolated by later grammarians, who applied the grammatical terms of their own time to ad-Du'alí.

As for 'Alī's role: he is said to have instructed Abū 'l-Aswad as follows: 'Language is noun and verb and particle; noun is what gives information about the nominatum; verb is that by which information is given; particle is what comes to a meaning'. ${ }^{30} \mathrm{We}$ do not know if there is any truth at all in this tradition; maybe we should ascribe it to $\check{S}_{i}{ }^{-}$ite partisanship, as Nöldeke does, with the traditions about 'Alī having been the first to collect fragments of the Qur'ān. ${ }^{31}$ We certainly do not know whether this story may be connected with Greek influence-not even when we find Ali using at least one Greek word, namely the word qälün (i.e., Greek kalón, 'good!'), in normal

I, 1, 7; Misra, 1966, 17-8 On Iceland: Gordon, 1957², XLIV sqq On China: Karlgren. 1926,$47 ; 63 \mathrm{sqq}$

${ }^{28}$ Semaan, 1968, 11 sqq This is confirmed by the fact that the Syriac name for the vowel 'a' (Arabic fatha), ptähā already existed at the time of its supposed invention by ad-Du'ali, cf Tarazi, 1969, 115. Later Arabs were aware of this Syrlac influence, cf Semaan, 1968, 18, n 2 On the vocalızation in early Arabıc manuscripts: G. Bergstrả Ber/

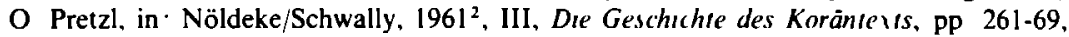
where different traditions about the invention of the vocalic stgns are mentioned as well.

29 'He laid down the chapter of the doer and of whom it is done 10' (fa-wada'a bāh al-fā'll w'a-'l-maf ū $)$, Sir. Ahb 18, 10; 'he (sc. "Alī) pointed out to him (sc Abū 'l-Aswad) the nomınatıve, the accusatıve, and the genıtıve" (ašära lahu ıla 'r-raf w'a-'nnasb wa- /-garr), Abū 'ț-Tayyıb al-Lugawi, Maräıb an-nahwiyyin, ed. M. A Ibrāhim, Qāhira, 1954, 6, 13-4; the question whether or not declension still existed in spoken Arabic at this time is irrelevant to this point of view, since what matters is, whether grammarians were convinced of the necessity of preserving the correct declensional endings. About this question: Fuck, $1955^{2}, 1-5,8-10$, and the critical remarks of Spitaler (Bıblıtheca Orientalıs, 10, 1953, 144 sqq.) and Wehr (ZDMG, 102, 1952, 179-86).

${ }^{30}$ b. Anb. Nuzha, 4, 9-11 [A 2], cf below, chapter III A

31 'An alledem ist keın wahres Wort': Nöldeke/Schwally, 1961 ${ }^{2}$, II, 8-11, of Wild, 1965, p 5 , n 20 
conversation ${ }^{32}$ If we were able to go further back into the history of Arabic linguistics, and if we had reliable information about the way grammar was taught prevıously to al-Halil (d 791/175) and Sibawarhı (d 793/177), we could perhaps extend our conclusıons concernıng Greek influence to the first period of Arabic linguistıcs, but given the present state of knowledge this is impossible

About the period following on Abū 'l-Aswad's activities information is almost completely absent, except for a few names of authors and tıtles of books, but at the tıme of al-Halìl and Sibawaıhı, about a century after Abū 'l-Aswad, we find an Arabic grammar that has reached a high stage of perfection Nothing is left of al- $\underline{\text { Halill's own }}$ writings the Kitäb al-'ain, the first lexıcographical work of Arabic literature, was certainly not compiled by him alone, although he seems to have invented the system of arranging the radicals and the phonetic principles underlying this arrangement $\mathrm{H}_{15}$ phonetic theories are probably due to Indian influence, and maybe we must also reckon with Syrian influence ${ }^{33}$ Halïl's grammatıcal writıngs are lost, but according to Reuschel the grammatical system which is found in Síbawaihı's Kıtāb is to a substantıal degree $\underline{\text { Halill's }}{ }^{34}$ It does not seem very probable a prior that this balanced system with its advanced termınology should be the result of a natural development in the course of less than one century It has been objected that Sibawaihı lived too early to have undergone the influence of the translations of Greek writıngs, this is even more the case with al-Halil But, true though it is, this argument cannot be used in favour of the independence of Arabic grammar, since there is another factor to be reckoned with Everything points to the fact that these first real grammarians did not have anything to do with the Aristotelian logic of speech, but with the living practice of grammar which existed all over the Near East

We do not agree with Madkour's statement that 'ces grands fondateurs al-Khalī et Sibawayh vivaient au milieu du mouvement traducteur de l'Islam', ${ }^{35}$ which is contradicted even by Madkour's own account of the history of the translations he situates their apogee at the end of the 8 th/2nd and the 9 th/3rd century ${ }^{36}$ Besides, his

32 Ta’ālıbi ap Suy Muzh I, 163 ult , cf Lisān, s v qln, 13, 347r

33 Wild, 1965, 37-40, manuscripts of the Kıtäb al-"ain ib, 9-13, edition by "A Darwìs, Bagdād, 1967 (Ist part)

34 Reuschel, 1959, cf the index of quotations from al-Halil in Sibawaihı's Kıtäb, to be supplemented by Troupeau, 1961

${ }^{35}$ Madkour, $1969^{2}, 17$

36 Madkour, $1969^{2}, 26$ 
comparison of the grammatical qiyās with the logical syllogism is certainly wrong, ${ }^{37}$ and the argument based on the division into three parts of speech, ism, $f i l$, and harf as compared with Aristotle's tripartition in the De Interpretatione is not decisive at all. ${ }^{38}$ In our view, Arabic grammar was indeed influenced by Greek logic, but this influence took place at a much later date, when Baghdad had become the centre of Arabic culture.

When Merx in his Historia artis grammaticae apud Syros tried to prove the dependence of Arabic grammar on Greek logic, he used mainly terminological resemblances. His most important arguments were: ${ }^{39}$

1. the notion of declension and the term $\vec{i}$ räb

2. the division of words into three parts of speech

3. the distinction of two genders

4. the distinction of three tenses

5. the notion of zarf (local or temporal adverb)

6. the notion of häl.

We believe that these arguments do not prove the influence of Greek logic, but contact with Greek grammar. The first two arguments will be discussed in the second chapter, as well as the fourth argument. The third argument is trivial. The case of the term zarf, which is traced back to Aristotle's angeion (vessel, jar), is stronger, and it does not seem possible to refute its value as an argument for the influence of logic on the beginnings of Arabic grammar. Still, the combination of time and place, which underlies Merx' identification of the two terms, is not typical of Aristotle alone, since it may also be found in Stoic theories, and is present in a Latin work about grammar. ${ }^{40}$ It is therefore not too unlikely that somehow the word angeion came to be used in Greek grammar with the technical meaning of 'temporal or local adverb' (which envelops as it were the action taking place in it, just like a vessel does), which is the meaning of the Arabic word zarf, though not the meaning of the Aristotelian angeion, which means 'temporal or local circumstance'. Nevertheless, this is purely

${ }^{37} \mathrm{Cr}$ below, chapter IV

3* Cf below, chapter III A

${ }^{34}$ Merx, 1889, 141-8 (ea vero, in quibus Grammatici notıonibus ab Aristotele propositis usi sunt, haec sunt )

40 SVF 2, 331, Varro, De L L, 5, 10-2 Is there any connection with the Stoic term pandehtes (adverb), did this lerm ever have the meaning of 'vessel, container"? 
hypothetical, and the fact remains that nothing much can be argued against Merx' identification. As for hăl, usually defined as 'condition, appearance of the active and the passive person', ${ }^{41}$ this is compared by Merx to the héxeis kai diathéseis, which in Aristotelian technical language mean 'permanent and temporary qualities and states'. But on the other hand, Merx himself tells us that the Arabic hal corresponds to diathesis alone, so that the distinction between permanent and temporary qualities has disappeared. Besides, hăl has been connected by others with the Stoic pôs échon, one of the four Stoic categories. $^{42}$ There is also the possibility that the Arabic use of the word corresponds to the use of diathesis in Greek grammar, which not only means 'verbal voice', as Merx asserts, ${ }^{43}$ but is also used for the verbal mood, i.e., for the expression of a mental condition (psuchike diáthesis). ${ }^{44}$

Our theory advocating a direct contact between Arabic grammarians and Greek scholars, possibly with the Syrians as intermediaries, is further confirmed by the history of Stoic influence on Islamic logic, theology, and philosophy. Most scholars assume a so-called vore diffuse to be responsible for those similarities between the two doctrines which cannot be explained by influence through translations of Greek writings. ${ }^{45}$ This voie diffuse consisted in direct contact with the cultural centres of Hellenism, and especially with the monasteries and learned clergy. ${ }^{46}$ This contact had been established even before the beginning of Islam, by those Arab tribes that had been christianized, and it was maintained on a much larger scale after the conquest of Egypt, Syria, and the other Hellenistic territories where Muslims and Christians had to live together in the same cities. We should keep in mind that the clergy were generally in charge of passing on and teaching literature and the sciences, and that they were trained in such disciplines as grammar and rhetoric. A typical case is that of Jacob of Edessa, who asks whether it is allowed for a Christian presbyter to teach Muslim children. ${ }^{47}$ In later times, these

41 b Anb Asr 77, 9, Zam Mul 27, 18

42 Rescher, 1966, 80

43 Merx, 1889, 146

44 Steinthal, $1891^{2}, 275 \mathrm{sqq}$

45 Jadaane, 1968. 45 with further relerences, dlso Amıne, 1959, 97

4h On the mondsteries in Syria in the 4th century A D Festugiere, 1959, $311-6$

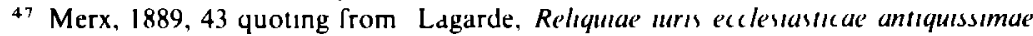
syricae, 1856, p 140, quaestio 48 
Christians came to Damascus and Baghdad, where they sometimes obtained high functions in the administration and in education. ${ }^{48}$

Not only the Christian clergy were active in this process : we must also reckon with the professional translators, who had to have a professional interest in grammatical matters. Halil has been mentioned as one of the teachers of the most important of all translators, Hunain ibn Ishāa, but this is contradicted by chronology: al-Halīl died at the latest in $791 / 175$, whereas Hunain lived till $873 / 260$ or $876 / 263 .^{49}$ Nevertheless, Hunain had predecessors and other teachers, from whom he received his knowledge of Greek grammar. ${ }^{50}$ One of the first translators was the Byzantine Roman Yahyā ibn Biṭrīq, who lived during the reign of the caliph al-Mansuur (754/137-775/159). ${ }^{51}$ This means that Arabic linguists were or could have been acquainted with methods and rules of Greek grammar well before the times of, say, al-Māzini (d. 863/249), the teacher of al-Mubarrad (d. 898/285). These methods were totally different from the logical theories of Aristotle, which were to have a considerable influence through the commentaries of Ammonios, Porphyrios, and others. In order to prove this difference we shall have to show that there is a fundamental difference between linguistic activity in the period of al-Halīl and Sibawaihi, and that of later linguists, who were concentrated mostly in Baghdad. Then we shall have to prove that this difference may be explained in terms of a different foreign background, and that those foreign elements which may be found in the work of Sibawaihi and other early grammarians should be attributed to direct contact with living grammar, whereas later authors in the Baghdadian period underwent the influence of translated Greek writings.

An interest in grammar was to men like Sỉbawaihi and his immediate predecessors and successors not theoretical, but only a means to a single goal, substantially the same one as Abū 'l-Aswad had had, namely to create some order in the immense material of the Arabic

48 On the position of the Christians in the Islamic empire Nau, 1933

49 Incorrect Brockelmann, GAL S I, 366, cf Gabriel,, 1968, 283, Braunlıch, 1926

so The first group of translators was concentrated around Ibn al-Muqaffa' (GAL I, 158) in the reign of al-Mansūr (754/137 - 775/159), and had connections with Christıans from Harrān, the most ımportant among them beıng Tābıt ıbn Qurra (GAL I, 241, S I, 384) The former was a pupıl of Johannes Damaskenos Cr Peters, 1968, 5960 Peters mentions elsewhere $(1968,134, \mathrm{n} 136)$ a typescript thesis by $G$ Afnan, La connaissance du grec parmi les philosophes islamiques, which I have not been able to find

st $\mathrm{Cr}$ below, chapter IV, note 26 
language. This they tried to achieve by means of a few fundamental notions, which very often were not defined at all, or defined in a descriptive way. The basis of their theory of language was the natural instinct as to the correctness of speech, which the pure Arabs were assumed to possess. ${ }^{52}$ Many terms were used in a non-technical way, for instance the term ism (noun). ${ }^{53}$ The notion 'verb' was described in the following way: 'As for the verbs, they are patterns taken from the expression of the events of nouns, and they are constructed to (signify) what is past and what is to come and what is being without interruption'. ${ }^{54}$ This is not to be taken as a definition-as, for instance, Zağğăği seems to do-, ${ }^{55}$ but as a simple reminder of the fact that verbs are derived from the masdars, and that they occur in various forms which are expressive of tense; in other words, it is not a definition of the essence of the verb such as we find with later grammarians-, but a description of something that happens in speech. Non-technical terms are found for instance in the chapters about the passive and about the various forms of transitivity. ${ }^{56}$ Sibawaihi's Kitäb could be called a diwān of all the curiosities and nawädir of the Arabic language, but as such it operates on a very high and accomplished level, rarely attained by later grammarians. It is difficult to imagine that in the fifty or sixty years following Abū 'l'Aswad's first endeavours, Arabic grammar could all on its own have assumed such large proportions without any foreign influence. The absence of Aristotelian influence should not be interpreted as an argument for the thesis that grammar was a purely Arabic science untainted by any foreign elements, nor is it surprising that there is no clear evidence of foreign influence, as long as we take the view that the first contacts with the Greek world were direct, as it were 'unofficial', contacts with the living instruction of grammar at the Hellenistic schools and universities.

In the following three chapters we will discuss some elements in Arabic grammar which we believe to have been coined on Greek

$52 \mathrm{Cr}$. Mubārak, $1974^{3}, 63-4$ (dauq al-arab), for the story about al-Halîl's sources for the study of the 'ilal, cf. below, chapter IV, note 76 .

${ }^{33}$ Sıb Kit. 1, 2, 2: 'The noun is rağul (man) and faras (horse) and hä’ı! (wall)'. CC. Zağğ Id $49,9-10$ (without hä̀i!)

54 Sib Kil 1, 2, 2-3 [A3], cf. below, chapter III A.

ss Zağğ Id 53, 1-5 Zağğăği refers to his Sarh ar-rısāla where he dealt with this question more fully Nothıng is known about this work except for what he tells us hımself in the Idạh $(41,11 ; 53,5)$. On the Rısãla: cf below, note 78 .

so $\mathrm{Cr}$ Sib. KIt. 1, 13 sqq 
examples; these elements are: the terminology of articulated sound and of phonetic change; the term haraka (vowel); the definitions of noun and verb; the paradigms for noun and verb; the theory of the parts of speech; the notion iräb; the verbal tenses; the theories concerning the infinitive; the concept of transitivity; the system of the usül an -nahu: We wish to make clear from the start that we do not agree with Weiß's methodological remarks about the borrowing of systems or doctrines. Weiß vigorously opposes the thesis of Greek (and even Latin) influence on Arabic grammar, and states that it is methodologically wrong to look at one isolated term, since every term is part of a complicated system, without which it is meaningless. ${ }^{57}$ One must, of course, concede that his opinion arises from the laudable wish to prevent wild conjectures, but his appeal to the psychological improbability of the borrowing of single elements out of their context is contradicted by modern studies, notably by Barwick's studies concerning the relationship between Greek and Latin grammar. We firmly believe that one of the characteristics of grammatical systems is that each element tends to lead its own life outside the original framework. This is, indeed, the cause of such misunderstandings as arose-and still arise - in grammatical problems. We do agree, of course, with Weiß that one should not postulate a dependence on Greek sources without sufficient proof.

The current opinion about the dependency of Arabic grammar on Greek examples is expressed by Fleisch in the following words: 'Des influences grecques sont à signaler: la spéculation grammaticale arabe a emprunté des concepts initiaux à la science grecque, non pas à la grammaire grecque, mais à la logique aristotélicienne'; and: 'Ceci réduit beaucoup l'influence grecque; munis de ces concepts initiaux aristotéliciens, que la simple ambiance a pu leur foumir, les grammairiens arabes ont travaillé avec leur mentalité arabe; la description des catégories grammaticales est arabe; l'agencement en un système est arabe, si bien qu'on peut dire que, de toutes les sciences isla-

57 WelO, 1910, 389-90 'Handelt es sich gar wie bei der Grammatik und Philosophie um ein wissenschaftlıches System, so erscheint von vornherein der Versuch, auf Grund bloß gelegentlicher Übereinstimmungen eine Beeinflussung nachzuweısen, als ein sehr wenig aussıchtsreıches Beginnen, insofern die zahlreıchen Divergenzen die eventuelle Beweiskraft der Kongruenzen gründlıch paralysıeren; denn man darf nicht ubersehen, $\mathrm{daB}$ ein System ein Ganzes darstellt, und daB es psychologisch ganz unwarscheinlıch ist, $\mathrm{daB}$ ein emzelner Begriff daraus wie ein erratischer Block gewandert sein soll, ohne Spuren sogar seiner nächsten Nachbarschaft mitzunehmen'. 
mıques, la grammaıre est peut-être celle quı a le moıns subı d'ınfluences exterieures et est restée la plus purement arabe' 58

In the following chapters we shall try to show that there is more than one reason to reject, or at least to modify this theory, namely that all traces of Greek influence which may be detected in Arabic grammar should be attributed to Greek logic It appears that the influence of $\operatorname{logic}$ was at first almost non-existent, or only filtered through to a small degree along the vole diffuse, $1 \mathrm{e}$ via direct contact between translators and grammarians, whereas the real influence was exercised by Hellenistic educational institutes with their long-standing tradition of grammar-teaching Sometımes, Syriac grammar must have acted as intermediary Logic became important as Greek philosophical writıngs were gradually translated from Greek into Arabic, mostly indirectly via Syriac Its influence came to be felt in linguistics with the rise of the so-called 'philosophical school', which has long been regarded as a special group of philosophically minded scholars who were also interested in grammar and language, ${ }^{59}$ but which we believe to have been nothing more than the development of linguistics after the introduction of logic into the Arabic world under the influence of the Mu'tazila ${ }^{60}$ The rise of this 'philosophical school' coincides with the transference of the centre of linguistics from Basra and Küfa to Baghdad As for the first period of Arabic linguistics, the chronology of the translational activities compels us to reject any appreciable influence of logıc before, for example, Hunaın ıbn Ishāq Thıs opınıon is confirmed by the study of those linguistic elements which may be traced back to Greek grammar Viewed in this light, the problem of the sudden appearance of a complete model of grammar with al-Halil and Sibawaihı ceases to be a problem the Arabian conquest of the culturally superior civilization that was Hellenısm, the geographical location of Bașra and Küfa near Hellenıstic centres of education, the fact that there were many bilingual people, and the presence of some striking simılaritıes between Greek and Arabic grammar, these are the main points of our evidence for the thesis of a direct contact between the first representatives of a new method of describing language and the last representatives of the old

In two articles, Les origines de la grammaire arabe and An Arab

\footnotetext{
s8 Fleısch, 1961, 23

s9 Kraus, 1942, 2, 251, n 2

${ }^{60} \mathrm{Cf}$ below, chapter VIIl
} 
grammarian of the eighth century A.D., ${ }^{61}$ M.G. Carter attacks the - what he calls-thèse helléniste. In our view his theory that Arabic grammarians were influenced by Arabic theories and methods of law is not as incompatible with our theory as one would think at first sight.

Carter believes that every form of linguistic study preceding Sibawaihi-i.e., the period of orthographical innovations, and the period of the group of nahwiyyüna (les gens concernés par la façon de parler) ${ }^{62}$-had been the work of amateurs. Sibawaihi was the first real grammarian. In his Kitäb he brilliantly undertook to assemble the linguistic facts, which form part of a social system, into a juridically organized corpus. His purpose was the description of linguistic behaviour, a normative grammar of the kind that was customary with later grammarians. At the time of Sibawaihi's activities there existed an abstract legal system set up by Islamic lawyers in order to analyse laws and traditions: this proves that Sibawaihi did not need any abstract Greco-Hellenistic theory for his grammatical system.

Sibawaihi had at his disposal two sets of terms. ${ }^{63}$ In the first place he used a series of already existing terms for the categories and phenomena of the Arabic language. These terms may or may not have been modelled on Greek examples. In the second place he used a set of operational-functional terms, which are borrowed from the legal system.

Carter adduces four important terminological arguments :

1. the use of moral criteria in grammar (hasan, 'good'; qabih, 'bad') ${ }^{64}$

2. the qiyās is a juridical method ${ }^{65}$

3. the terminology of maudi etc. is derived from the study of law ${ }^{66}$

4. a great deal of linguistic terms have a juridical connotation (e.g., sart, 'condition'; 'iwad, 'compensation') ${ }^{67}$

Furthermore he points out that there were many contacts between lawyers and grammarians. Sibawaihi himself had started his educa-

61 Carter, 1972; 1973, cf. also id, 1973b.

62 Carter, 1972, 76-7

63 Carter, 1972, 80; 81-2.

64 Carter, 1972, 83, 1973, 147-50

os Carter, 1972, 84.

66 Carter, 1972, 84-5; 1973, 147-8

67 Carter, 1972, 86. 
tion as a student of law, and lawyers often needed the help of grammarians for the explanation of linguistic subtleties in legal texts Carter concludes that if it can be proved that the science of law furnıshed the examples for Sibawaıhı's theory of speech, the Greek hypothesis has lost its raison d'être In his view the Greek hypothesis is a prior improbable because of the complete silence in Arabic sources concerning any dependency on Greek examples What is more, Greek grammar is of a completely different character

Carter's observations conceming the relations between grammar and law in the Islamic world are certainly very plausıble, but they do not rule out Greek influence We agree with Carter that borrowing grammatical terms does not imply a total dependency, Arabıc grammar is a linguistic system in its own rights Our point is that the early Arabic grammarians borrowed several elements from Greek grammar in order to buld their own system The argument $e$ silentio is very strong, indeed, but presumably religious reasons as well as patriotic feelings played a role in this respect, and we can certainly appreciate that grammarians were more sensitive about the purely Arabic origin of their discipline than physicians or philosophers ${ }^{68}$

Apparently Carter agrees with this point of view when he says about the fundamental notıons of Arabic grammar-Sibawaihı's first set of terms - 'certains de ces termes peuvent avoir une éventuelle orıgıne grecque', but he adds that 'même dans le cas peu probable où on pourrait trouver la trace de tous ces termes dans le grec ils représentent quand même un groupe fort restreınt par rapport à l'ensemble de la termınologie du Kıtäb' 69 We do not assert that Arabic linguistic thinkıng was a copy of Greek grammar, but we do believe that the instruction of Greek grammar was the model and the startıng point for Arabic grammar It is generally difficult to trace exactly the way transmission took place, but there is an unmistakable similarity between the two grammars in their categorization This first influence was, of course, quite distinct from the second wave, after the introduction of the Corpus Aristotelicum into the Islamic world the second wave is concerned much more with linguistic method and linguistic philosophy than the technical aspects of grammar

${ }^{68}$ Cf below, chapter VI, notes $36-7$

${ }^{69}$ Carter, 1972, 80 We believe, indeed, that the Greek origin of many of the terms

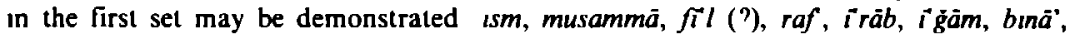
haraka, ta'alluq, mādı, ma'nā, kalām, qaul, 'adala, șarf, fā'ıda, mufid, șahıh, mu'tall (cf Carter, 1972, 83), ta'addl 


\section{As for Carter's terminological arguments :}

ad 1.It is true that in describing linguistic facts Sibawaihi uses terms that are also used for moral categories; there may be a connection with the study of law, but we must also point out that in the Hellenistic and Byzantine periods there were many treatises about the aretai kai kakiai tès léxeôs (virtues and vices of speech), i.e., about correct and incorrect speech. These treatises had been an integral part of the Stoic téchnai, and through the téchnai they were introduced into rhetorical education. ${ }^{70}$

ad 2.The origin of the linguistic method called qiyās may well lie in juridical practice. We shall try to demonstrate the connection between the set of four criteria of scientific analysis in the Islamic world on the one hand, and on the other hand the method of the empiricist physicians in the Greek world. ${ }^{71}$ Whether grammar obtained its kind of qiyās through law, or through another discipline, or even independently, is not very relevant. All the same, there is the matter of chronology: according to Schacht aš-Săfi'i was the first to codify the juridical ușül, so that the question arises whether such a system could already have existed at the time of Sibawaihi. We would rather favour a dependency on medical studies in this respect.

ad 3. The terminology of maudi etc. ${ }^{72}$ We agree with Carter that this set of terms is a genuine Islamic invention, but we do not know whether its grammatical application is really derived from the legal system.

ad 4.Carter's assertion that such terms as sar! (condition), 'iwad (compensation), badal (replacement), hadd (definition), ḩuğğa (argument), niyya (intention) - we might add the important term ğaza (requital, recompense; in grammar: the protasis of a conditional period) - have a juridical flavour, is plausible enough in itself, but the argument needs to be developed more fully.

We cannot accept the picture of a spontaneous creation of the linguistic corpus at the hands of one man. The character of the oldest extant grammatical literature supports much more Sezgin's

70 Barwick, 1922, 95-9, Donnet, 1967, 154-6, of also Apoll Dysk index, s v kakia (mala dictio), Quint inst orat 1, 5, 1 virtule's vs vita Mustaqim may be related to Greek orthós

7 Cf below, chapter IV

${ }^{72} \mathrm{Cf}$ for this termınology Weil, 1913, 24, n 3, Carter, 1973, 147-9, below chapler VII, n 86 
conception of the history of Arabic scientific literature, 'wonach z.B. dem monumentalen grammatischen Werk von Sïbawaihi eine vorbereitende Literatur vorangegangen sein muß und die umfangreichen Bücher von Historikern derselben Zeit, wie z.B. ibn Ishāa und Saif b. 'Umar, Kompilationen früherer Schriften darstellen und zahlreiche Qur'ānkommentare des ersten Jahrhunderts der Hiğra in den späteren Werken verarbeitet wurden'. ${ }^{73}$ We assume that Sibawaihi borrowed a great deal from written sources, even if this borrowing took place under the supervision of a teacher. We do not possess much information about the organization and methods of instruction and education of the early grammarians, but we suppose that Sezgin's conclusions concerning the muhadditüna and the mu'arrihüna are also valid for the nahwiyyuna. Some of the terms with which Sïbawaihi introduces his quotations from earlier grammarians refer in that case to the modality of transmission, not to the value of the contents of the quotation. $^{74}$

According to this conception the nahwiyyuna who are mentioned by Sïbawaihi-Halīl ibn Aḥmad, Yūnus ibn Habīb, Abū 'Amr ibn al-'Alā', al-Aḥfaš Abū 'l-Hatțāb, 'Tsā ibn 'Umar a.o. ${ }^{75}$ —should not be regarded as mere amateurs interested in linguistic curiosities. According to Reuschel a great deal of the facts and theories collected in the Kitäb are the result of a linguistic tradition, although it is true that Sibawaihi marks the culminating point of this tradition, and that he represents at the same time a remarkable technical innovation in grammatical description. ${ }^{76}$ The difference between the nahwiyyūna experts in traditional linguistics ${ }^{77}$-and Sïbawaihi is that Sỉbawaihi organizes the linguistic facts into a consistent whole. Reuschel refers to the fact that only in the first seven chapters of the Kitäb-the so-called Risâla ${ }^{76}$-does Sibawaihi not quote any of the older gram-

73 Sezgin, 1967, 393

${ }^{74} \mathrm{Cr}$ the table of the terms used by Sibawashi in introducing a quotation from Halil- Reuschel. 1959, I1, he suggests that the difference in the terminology is indicative of a different 'Wertung der Aussagen Halils', ib p. 10, n 2, but of Sezgın, 1967, 58-60; 77-9, 240-1.

75 For these scholars, of Brockelmann, GAL I, 96-8; S I, 158-60

76 Reuschel, 1959, 7-8

${ }^{77}$ Perhaps Carter's explanation of the term nahu in nahuryyüna as 'façon de parler' is correct, but he is not right in regarding the nahwy'yuna merely as interested laymen.

${ }^{7 *}$ Accordıng to Mubārak, 1963, 112-3, the Rısäla comprises the first seven chapters of Sibawaihı's Kıäh (Kıt $1,1-13$ ). Commentarıes written exclusively on the Rısäla are known from Zağğāği (cf above, note 55) and also from al-Aḥfaš as-Sagiir $C f$ the remark in an editorial note in one of the mss of the Kitäb (mentioned by de Sacy, 
marians. This may be significant inasmuch as these first chapters discuss precisely the fundamental notions of grammar, and mark the beginning of a really technical grammar. In our view this achievement was partly influenced by the growing acquaintance with Greek grammatical practice.

On the other hand Carter is certainly right in supposing that the juridical system exercised a considerable influence upon the Arabic grammarians of this time, just as it is true that there has always been an intimate relationship between the two disciplines, especially in the discussions about the ușül, the 'illa, the qiyās and other subjects that touch on the methodology of the discipline. However, in this case there is more a similarity in methods than a dependency of grammar on law. ${ }^{79}$

In our view Arabic grammar is far from being a slavish imitation of Greek grammar. What may be the most startlingly original trait of Arabic grammar is that it applies the theory of a natural balance (mizān) to language; this results in a conception which views speech as a harmonious structure, in which every constituent part has its rightful place, ${ }^{80}$ which it cannot lose without repercussions in the rest of the system, or without being compensated. This conception is not paralleled by any Greek theory. We refer to Weil's introduction to the Insajf for a discussion of the grammatical consequences of this theory, and to Kraus' study about Gābir ibn Hayyān for a discussion of the methodological background of the theory of the natural balance, as well as its sources. ${ }^{81}$ We are fully aware that in trying to prove the presence of Greek influence we have given far too little attention to this and similar aspects of the originality of Arabic grammar.

1829, 382, lıne 19) that Ismā'ill al-Warrāq copied the Rısāla of the Kırāh, as well as part

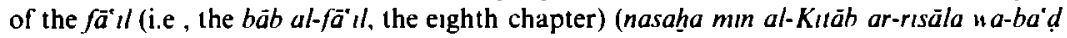
$\left.a l-f a{ }^{*}, l\right)$

79 Mubārak, $1974^{3}, 79-93$.

80 For the terminology of 'syntachic place' cf chapler VII, n. 86

B1 Weıl, 1913, 7-28; Kraus, 1942, 2, 187-303 (La théorie de la balance), (1b. 187). 'La science de la Balance ( $I / m$ al-mizän) a pour but de rédure toules les données de la connaıssance humaıne à un système de quantıté et de mesure, leur conférant aınsı un caractère de science exacte"; cf especially the sections 3 (la balance des lettres) and 4 (la philosophe du langage): Kraus refers to theories of Galenos and Plato as the sources of the "llm al-mizän 


\section{ARTICULATED SOUND AND ITS MEANING}

'Most scholars agree in thinkıng fit to begin the study of dialectics with the subject of sound' 1

In this chapter we will discuss a few aspects of the relation sound vs. meaning : the notion of a long vowel; the term haraka; the theory that a change in the sounds of a word affects its meaning; and the terminology of articulated sounds and their meaning. The phonetic studies of the Arabs lie outside the scope of this chapter $;^{2}$ it has been suggested that the first classification of the Arabic sounds in al-Halil's Kitäh al-ain was due to Indian influence since a similar classification is used for the Indian alphabet. ${ }^{3}$

The relationship between the three vowels and the so-called hurüf al-lin wa-'l-madd, i.e., the alıf, the wāw, and the $y \bar{a}^{\prime}$ had already been recognized by early grammarians: according to Sibawaihi a word can go eight 'ways' (maḡărî), in other words it may have eight different endings in declension. These eight endings form four pairs, because the alif and the 'a', the ' $w$ ' and ' $u$ ', the ' $y$ ' and the ' $i$ ' belong together; the fourth pair is formed by the nominal and the verbal zero ending. ${ }^{4}$ There were two opinions as to whether the letters are original, or the vowels, ${ }^{5}$ but the relationship between the two groups is acknowledged by both theories. The conception of a long vowel was fairly uncommon: vowels and hurüf al-lin wa-'l-madd are related, but they do not belong to the same category. There is a third theory, which regarded the hurüf al-lin wa-l-madd as long vowels.

In his treatment of the declension of the dual and the plural, Ibn al-Anbāri does not mention the theory of $\mathrm{Ta} \mathrm{a}^{\circ} \mathrm{lab}$, which is mentioned by Zağğăğĩ in the same context: ${ }^{6}$ Ta lab held that the alif, the $w \bar{a} w$, and the $y \vec{a}$ ' may serve as substıtutes of the vowels (abdäl al-harakät);

1 Diokles Magnes ap Diog Laert 7, $55=$ SVF 2, 136 [G I]

${ }^{2}$ Cr Schaade, 1911, Cantıneau, 1960, 19-25, Bravmann, 1934, Semaan, 1968

${ }^{3} \mathrm{Cr}$ Wild, 1965, 37-40

4 Sib Kit 1, 3, 2-3

3 Cr Zağğ Id 123, 9-13, b Anb Asr 127, 9-12

6 Zağğ Id 141, 10-2 
in the plural zaidūna the wāw' is the substitute of three ' $\mathrm{u}$ 's. We do not believe that this is a mere formal or functional comparison between two elements of speech, such as we find in other chapters of Arabic grammar, ${ }^{7}$ but we connect this isolated observation about Ta'lab's theory with other texts, and conclude that it forms part of a theory which differs from the general Arabic conception of vowels and letters.

Ibn al-Anbārīss second question in the Inșäf deals with the declension of the so-called 'six words', abun, ahun, etc. ${ }^{8}$ Ibn al-Anbārī quotes Māzinī, who says that the series $a b \bar{u}, a b \bar{a}, a b \bar{i}$ is derived from the series abun, aban, abin by lengthening of the vowels (išb $\tilde{a}^{\mathrm{r}}$ ). The Arabic term for 'lengthening' is normally used for a metrical phenomenon, namely the lengthening of a vowel in a line for metrical reasons. ${ }^{9}$ But we could also say that Māzinī departs here from the current Arabic conception: instead of 'long vowel $=$ vowel + letter' he says 'long vowel $=$ vowel + vowel', or 'long vowel $=$ lengthened short vowel'. In that case ' $u$ ' comes from ' $u+u$ ', just as Ta'lab said.

There is proof that such a conception actually existed in the Arabic world, and, what is more, that it was explicitly connected with Greek theories. In the section about grammar in Hwārizmī's Mafätịh al-ulüm there is a chapter about the ways of declension 'according to the doctrine of the Greek philosophers' ('alä madhab faläsifat al-yünäniy$y$ in $) ;^{10}$ it is probably a quotation from the work of Hunain ibn Ishāa, who wrote about Greek and Arabic grammar. ${ }^{11}$ Hwārizmī says that 'the logical scholars of the Greek people call the nominative an imperfect $w \bar{a} w$, and likewise the "u" and her sisters ..., and the "i" and her sisters are in their view an imperfect $y \vec{a}$, and the "a" and her sisters are in their view an imperfect alif. But if you wish to do so, you may also call the long, soft wāw a lengthened " $u$ ", and the long, soft $y \bar{a}$ ' a lengthened " $i$ ", and the long alif a lengthened " $a$ ". ${ }^{12}$

${ }^{7}$ For instance the article and the ıdafa, which have the same function, and may, therefore, take each other's place, i.e., they have the same maudit, though not the same manzıla.

${ }^{8}$ b Anb. Ins. 6, 11-12, 25

- The term $ı s ̌ b a a^{*}$ is explained by Ibn al-Anbārī, two of his examples are also found with Ibn Gınni, Haș. 3, 136, I, in a passage about the $ı \xi \bar{a}^{\circ}$-theory in connection with the declension of the dual and the plural. Possibly both authors quote from a work of al-Mảzıni

10 Hwār. Maf 46, 3-10

11 Cf below, chapter VI, note 23 .

12 Hwār. Maf. 46, 48 [A 4]. 
This quotation shows that the conception of long vs. short vowels instead of short vowels vs. short vowels + alif, $w \bar{a} w, y \bar{a}^{\prime}$ was felt to be connected with the declension and with Greek sources. Perhaps this may be explained in the following way: Arabic translators and logicians by virtue of their knowledge of the Greek language and of Greek grammar tried to improve the theories of Arabic grammarians by showing that the difference between zaidun and zardūna, and between abun and $a b \bar{u}$ is nothing else than an alternation of long and short vowels. It is quite understandable that this 'improvement' was misunderstood in the course of time and became a separate type of declension, or was confused with a metrical phenomenon.

Ibn. Ginni mentions as one of the reasons for the resemblance between letters and vowels that the vowel is a small letter (harf sagir): 'Don't you see that some people in the past used to call the " $u$ " the small $w \bar{a} w$, and the " $\mathrm{i}$ " the small $y \bar{a}$, and the "a" the small alif?"13 The same terminology of the vowel as a 'small letter' is found in Sirrāfì's commentary on the Kităb, ${ }^{14}$ and with Gābir ibn Hayyān. ${ }^{15}$ Bravmann mentions a phonetic theory according to which an alif is composed of two 'a' 's, a wa'w' of two " $u$ 's, and a $y \bar{a}$ ' of two 'i"'s, and alif, $w \bar{a} w, y \bar{a}$ ' are the result of pronouncing a vowel with $i s ̌ b a ̈{ }^{16}$

Arabic philosophers use another terminology for the sounds, taken from Aristotle, who divides sounds into phônènta, hèmiphôna, and áphona. ${ }^{17}$ In this division there is a special category for the continuous sounds, the hemiphona, for which the ' $r$ ' and the ' $s$ ' are given as examples. This terminology is found in Arabic translation, for instance in Ibn Sinā, who divides sounds into three groups: voiceless sounds (șāmitāt), i.e. the consonants; semivoiced sounds (allati lahā nisf șaut), i.e. the fricatives; voiced sounds (musawwitāt), divided into long and short voiced sounds (mamdūda wa-maqșüra). ${ }^{18}$ In the last group the maqșüra are the vowels and the 'weak letters' (hurüf al-'illa),

${ }^{13}$ b Gin Has 2, 315, 7-8 [A 5]

$14 \mathrm{Cr}$. Hegazi, 1971, 71-2, the passage from Sirāfìs Sarh is quoted by Mubārak, $1974^{3}, 118-9$.

15 Kraus, 1942, 2, 244, n. 1.

16 Bravmann, 1934, 13, quotıng from 'Alī ıbn Sultān al-Qārī's (d. 1014/1605), Kıtäh al-minah al-fikriyya alä main al-Gazariyya, ed. Caıro, 1308 A H, p 50.

17 Arrstot. poet 1456 b 24-30, cf Stcinthal, $1890^{2}$, 1, 254 sqq.; Bravmann, 1934 , VII-VIII, and note 2

18 b Sinā, Sìr, 191, 11-4. 
i.e., the alif, the $w \bar{a} w$, and the $y \bar{a}$, and the mamdìda are also called maddat, i.e., probably the long vowels.

The theory of short vowels as 'small' (sagir) or 'imperfect' (näqis) letters is connected by Hārizmi with the Greek world, so that we would expect the two terms sajigir and näqis to be related with Greek terms. In Hellenistic Greek the opposition between long and short vowels, and between diphthongs and vowels, had completely disappeared, at least in pronunciation; in writing, the traditional orthography was strictly maintained. ${ }^{19}$ Actually, the correct spelling of the vowels and the diphthongs formed an essential part of education and scholarship. For this purpose lists were made of words with their correct spelling, i.e. mainly whether to write 'o' or 'ô'; 'e' or 'ai'; 'u' or 'oi', 'ei' or ' $\mathrm{i}$ ' or 'è' for instance in the Herodian Epimerismoi. ${ }^{20}$ In the Epimerismoi, 'ei', 'i', and 'è' are indicated by their names (i.e. ei diphthongos, iôta, èta). ' $\mathrm{O}$ ' and 'ô' are referred to as o mikrón (little o) and $\hat{o}$ méga (big o); 'e' and ' $\mathrm{u}$ ' are distinguished from 'ai' and 'oi', respectively, by the addition psilón, i.e. 'bare, naked, separated from, simple'. ${ }^{21}$ Perhaps these terms mikrón, and psilón are the originals of sagir and näqis. This could explain why we find a different terminology with Ibn Sinā: he was dependent on the Aristotelian terminology, which originated at a time when the original opposition between long and short vowels still existed. ${ }^{22}$ Hunain ibn Ishāa and the other translators, however, leamed the Greek language as a living language. Perhaps they took the terms for the written vowels and introduced them into Arabic grammar.

The Arabic term for vowel, haraka (movement), has up till now been explained by only one theory, namely that of Bravmann. ${ }^{23}$

${ }^{19} \mathrm{Cr}$ Kühner/Blass, $1966^{3}, 1,1,41$, Anm 2; also Browning, 1969, 32-3

20 Herodianı Partitıones. Ed J. Fr. Boissonade. London, 1819 (Amsterdam, 1963) cf. about the epımerismoi, Glück, 1967, 35-40. These lists ultımately derıve from an Alexandrian grammarian of the second century A.D., Herodianos, the son of Apollonios Dyskolos.

21 Note that in the scholia on D T psilós is used as the opposite of dasus, $1 \mathrm{e}$ 'pronounced with a spirıus asper' (e.g scholıa D T 32-3); later o mikrón, ó méga, e psilón became names, cf. Liddel/Scott, s.v $\hat{u}$ and $\mathrm{s} v$ psilós

22 Steinthal, 1891², 2, 192 sqq.; 201.

23 Bravmann, 1934, 12-8. We do not take into account the explanation mentioned by Rāzi (Maf. 1, 48, 3-7). the voice moves from one sound to another in pronouncing a consonant with its vowel; a vowel is, therefore, a movement (haraka). Rãzi hımself disagrees, since it is not the vowel itself that is the movement Cf. also Rasä'll Ihwän as-Safa' $(3,136,2)$ : 'The movement (haraka) is the transferring (sc. of the sound) from one place to another in a second time' (about the expression 'second time': Bravmann, l.c.). 
According to Bravmann, haraka is a term from musical literature metre and rhythm consist in the alternation of consonants with and consonants without a vowel (hurūf mutaharrıka wa-sawäkın) Hence the original meaning of haraka was 'syllable', where syllable is interpreted as consonant + vowel The term itself is a calque of the Aristotelian kinèsis, which is used in the Physica for a specific form of change, namely the realization of something potential ${ }^{24}$ In this context, the vowel is considered to be the necessary condition for the realization of the consonant Fischer adds that in Greek poetical theory one of the primary characteristics of a syllable is its movability, $1 \mathrm{e}$, the fact that it may be compressed or extended According to him, this movability is also expressed by the Arabic term ${ }^{25}$ Both authors also point to a statement made by aš-Sātıbì (d 1193/590), that the vowel is the accident ( $a \mathrm{arad}$ ) and the consonant the substance (dāt), where the vowel is defined by means of logical terms ${ }^{26}$ The fundamental failure of this theory is that it does not take into account historical context Sibawaihı used the term haraka long before Aristotle's Physica became known in the Arabic world in the translatıon of Ishāq ıbn Hunain We must also point out that, as far as we know, nowhere in Greek logical or musical literature is kinèsis used with the meaning of 'vowel'

We propose to give another explanation with the help of Greek data There is a strıkıng termınologıcal sımılarıty between Zaǧğāğìs words 'It (sc the declension) is a vowel that enters speech after the completion of its phonetıc structure' (hiya haraka dähıla 'alä 'l-kaläm ba da kamäl bınä' $\iota h l),{ }^{27}$ and a text in the scholia on Dionysios Thrax where a grammatical case is defined as 'a movement that occurs at the end of a noun' (onómatos katà to télos ginoménè kinèsıs) ${ }^{28}$ That

24 Aristot phys 201 b 4

25 Fischer, 1964, 146

26 Quoted by Bravmann, 1934, 13

27 Zağğ Iḍ 72, 2-3

28 Scholıa D T 383, 3-4, 550, 24, cf also praefatıo, XLI, 2, and Grammatıcı Graect, IV, XXII, 12 Note the sımılarıty between $b ı \bar{a}^{\prime}$ (phonetıc structure, orıgınally construction) and suntaxis The Greek word has among its significations also that of the internal phonetic structure', e $g$ in the title of a book written by the grammarian Herodianos Peri suntaxeôs tôn stoıcheion (About the phonetıc structure of the elementary words), and especially in a phrase used by Apollonios Dyskolos 'the structures resulting from these (sc from the syllables) complete the word' (Apoll Dysk Synt 2, 7-8 About suntaxis Donnet, $1967^{\mathrm{b}}, 23-30$ ) We may also quote another phrase from the same author 'Every undeclinable part of speech has one and the same structure (suntaxis) in each gender' (Apoll Dysk synt 316, 8-9, cf synt 488, 5-6) In later Greek, suntaxis is also used with the same concrete meaning as binä' possesses in 
haraka and the grammatical term kinèsis are related may also be deduced from another parallel: the Greek word kineisthai is used in the sense of 'to be declined', ${ }^{29}$ and the word akinètos sometimes has the meaning 'undeclined'; ${ }^{30}$ in Arabic we find the word mutaharrik (set in motion) with the meaning 'declined'. ${ }^{31}$ That this word was already used at an early time is proved by a quotation from al-Halīl: "Al-Halil was asked about the nominative, why it is used for the agent, and he answered: the nominative is the first "movement", and the agent is the first "moved", and so they used the first movement to indicate the first moved'. ${ }^{32}$ This text also shows that the notion of movement was really felt to be connected with the declension.

It is not so strange that the word for vowel should be derived from the theory about the declension, if we consider that the primary motive of the Arabic grammarians was to preserve the Qur'ān from corruption. This corruption was mostly the result of a wrong use of the case endings: we fully appreciate this when we read the stories about Abū 'l-Aswad ad-Du'alí! ${ }^{33}$ Haraka as an equivalent of the Greek grammatical term kinesis was then originally the vowel par excellence, namely that vowel which indicates the cases : hense it came to be used as a general term for vowel. Elias of Tirhān, a Syrian grammarian (d. 1049/441) defines grammar as 'the knowledge of the movements of the nouns, the verbs, and the particles'. ${ }^{34}$ Even if the Syriac word zau'a or mettezi 'anūin $\bar{a}$ (movement) is a calque of the Arabic term, and not a translation of the Greek kinèsis, Elias' definition still proves that there did exist a definition of grammar in terms of movements, i.e. the case endings.

It is quite understandable that the term haraka was taken by later grammarians to indicate a real movement, for instance in the explana-

Arabic, for instance in an inscription from Ephesos 'the construction of the door-way' (he simtarss tou perithurou), Liddel/Scott, s v Nole also the similarity in meaning between the Greek word télos and the Arabic word kamäl (completion) The word hamäl was alreddy used for related words such ds teletotes, entelecheia (Daiber, 1968, 77). and a confusion between telos $=$ end and télos = fulfilment is easy to imagine

29 Scholia D T 230. 26, Sophr in Theod 2, 418, 17-8

30 Scholıa D T 427, 11, Apoll Dysk pron 70, 17, 71, 2, el passım

31 Abd al-Gabbār, Mugnī, 7, 205, I3 Abū Hāšım is quoted ds sayıng mutaharrık hi-raf an-nash an-garr (set in motıon by the nominative or the accusative or the genıtive)

32 Al- $\underline{H}$ dīil ap Zağğ Mağ 253, 12-4 [A6]

"Cf above, ch I, note 24, and e g Zağg ld pp 89-90

it Merx, 1889, 155 
tion of the names of the cases. ${ }^{35}$ They may have been influenced by the fact that vowels were also called 'voiced' (musawwität), ${ }^{36}$ and that a sound, according to Stoic doctrine, is a body because it moves. ${ }^{37}$ The ultimate consequence of this interpretation is found in the writings of the Hebrew grammarian Marwān ibn Ganāh, who compares the vowels to the three principal movements in the physical world, and classifies them accordingly. ${ }^{38}$

In the introduction of Weil's edition of Ibn al-Anbārī's Inșäf there is a long excursus about the various phonetic rules which were used, especially by the Bașrians, to explain changes in words, and deviations from the norm. These phonetic rules were axiomatic and they were accepted as an ultimate explanation of phonetic change. ${ }^{39}$ Three procedures are mentioned by Weil: change of a letter (qalb), metathesis (naql), and elision ( $h a d f)$. A fourth procedure certainly existed: the addition of a letter (ziyada) ${ }^{40}$ This system of phonetic rules is called $i l a l{ }^{41}$ i.e., an affection of the word, a deformation, which makes the word 'ill', as it were: essentially it is an offence against the laws of speech, against the harmony that ought to reign in linguistic structure - which is evidently thought of as an organic whole. Such affections are allowed in the case of poetry, when a poet has to change the form of a word for metrical reasons. ${ }^{42}$ But apart from poetry, such an offence can be tolerated only when there is a very good reason for a phonetic change, for instance when a change will make the word easier to pronounce. Even then, the change remains an 'illness', which makes the word unfit to be used in a grammatical analogy: the word remains a deviation from the norm. A word which

35 Zağğ Id pp 93-4

16 b Sinā. Sír. p 31

${ }^{37}$ SVF 2, 140, this doctrine was known to the Arabs through the translation of the Placisa Philosophorum, ed Dasber, pp 278-80, ef below, notes 44, 69, 70

38 Bacher, 1970², 9. Ibn Ganāh. Opuscules. 275-6. cl Chomsky’s notes on Kımhi’s Mikhlol, p 32, n 12

39 Weil. 1913. 10 'Die Geselze der Lautphysılogie, die die Araber schon fruh dufgestellt haben, gelten als unbedıngt giltige Erklarungen von Abweıchungen"

40 Cf for instance the hurūf $a z-z \vec{a}^{*}$ lda, the additıonal letters Ibn Ginni uses thıs catcgory to explain the ' $n$ ' in the word 'anhar, which is derived from the radicals ' $-b-r$. Has 3,66

4! Cr Zağğ Id pp 60, 4-5, 11-2 sahha, sthha and italla, iłlal Ibn Gınnī uses the expression itulal $h_{1}-\%$-qalb (an lllness as the result of a change), Has $1,377,17-8$, iläl hr' $\%$-hadl, ib 2, 155, 7

${ }^{42}$ This is called darüra (WeIl, 1913, 28), e g b Anb Ins 203, 9, 228, 18 In classical literature we find the term necessitas for the same phenomenon, e $g$ Quint inst 1, 6, 2 
is not affected by any of these changes is called 'sound' (sahih). In Syriac grammar the same terminology exists. We find there a distinction between words which are sound $(h \lim \bar{a})$, and words which are ill (krihā), just as in Arabic grammar. ${ }^{43}$ It is our contention that Syriac and Arabic terminology were influenced by a similar doctrine in Greek grammar. In that case, of course, the Syrians played an intermediary role in the contact between Arabic and Greek grammar.

In Greek grammar we are frequently confronted with the doctrine of the 'affections of speech' (páthè tès léxeôs, tès phônès), which describes phonetic change in words in terms of four categories. These categories were borrowed from the Peripatetic terminology of physical change, which distinguished between four categories: addition (prósthesis), elision (aphairesis), transfer (metáthesis), change (enallagè). It is no coincidence that these were borrowed by Stoic philosophers, since Stoic philosophers tended to compare linguistic facts with parallels from the physical world. ${ }^{44}$ The same tendency existed in Bașrian grammar: speech is the mirror of the physical world, the same laws apply therefore to both speech and nature. ${ }^{45}$ This specific conception of speech as a replica of nature-which in the case of the Stoa was caused by their materialistic philosophy: speech is part of the physical world, sound is a body ${ }^{46}$-resulted in both grammars in the same terminology: páthè and 'ilal are related in meaning. In both Greek and Arabic grammar it was customary to regard a word which did not undergo any change at all as being 'sound', i.e. not affected by any alteration. ${ }^{47}$

The Stoic method of analyzing phonetic processes is also used in Latin grammar, which provides us with a few more details. Varro

43 Tarazì, 1969, 115

44 Barwick, 1922, 98. 'Sie (sc the Stoics) haben eine auch für uns noch erkennbare Neıgung gehabt, dic Verhaltnisse der Sprache mit den Dingen der korperlichen Natur in Parallele zu stellen, eine Neigung, die man ohne weiteres versteht, da nach stoischer Lehre, das Grundelement der Sprache, die phône, eın sôma ist (Diog Laert VII 55)" About the physical categories. Barwick, $16,96-9$, especially p. 96 , note 5 , with loci from Greek literature concerning the division into four categories; cf also van den Bergh, 1954, 2, 2, 27.

4s Weil, 1913, 7 + note 1. Die Sprache ist nach streng basrischer Auflassung ein treuer Spıegel der Erscheınungen, Dinge und Begriffe, die sie zum Ausdruck bringt Daher mussen in ihr dieselben Gesetze wie im Denken, in der Natur und im Leben zu beobachten sein'.

46 $\mathrm{Cf}$ above, note 44 ; below, notes 69,70

${ }^{47} \mathrm{E}$ g. Theodosios, 14, 4, 14, 10 apathès, Apoll Dysk adv 156, 11, 160, 3, 200, 22 hugiès (phonetically correct) 
says: 'For (changes) are caused by the elision or the addition of letters, and also by their transposition or their change, likewise by the lengthening or shortening of syllables, and finally by their elision or loss'. ${ }^{48}$ The Stoic origin of the system is also proved by Varro's remark: 'Chrysippos and Antipatros ..., who both write that words are derived from other words in such a way, that some words take on letters, other words drop them, still other words change them'. ${ }^{49}$ The conception of phonetic laws as physical events which come about in a mechanical way, is of course older: we find it already in Plato's Cratylus. ${ }^{50}$

There is another, later, development of this doctrine in Greek grammar, which is usually connected with the name of the grammarian Tryphon, who lived in the first century B.C. ${ }^{51} \mathrm{He}$ used the same categories as the Stoa did, ${ }^{52}$ but he connected a change of sound with a corresponding change of meaning: the sounds suffer together with the meaning, as he put it: 'Limós (famine), the lacking of provisions. Limós comes from the verb leipo (to leave behind), future leipsô; it should have been written with a diphthong (sc. leimós), but the same happened to the sounds as to the meaning. The word indicates a lack, and that is the reason why it lacks a sound as well. Thus Tryphon'.53 We may compare with this the words of the scholiast on Dionysios Thrax: 'The form epoioun (I was doing) contains more of the past than the form poio (I do)'. ${ }^{54}$ Here the additional ' $e$ ' in the imperfect tense is explained from the grammatical meaning of the word. The difference

4: Varro De L.L 5, 6: Litterarum enim fit demptione aut additione et propter earum tralectionem aut commutationem, ttem syllaharum productione aut correptione, denique adiectione aut defrectione, of Quint. inst. 1, 5, 6 where the categories are listed as follows adiectio, detractio, Immutatio, transmutatıo.

49 Varro De L.L. 6, 1 = SVF 2, 154: Chrysippus et Antipater ..., qui omnes verha ex verhis "la declinart scribunt, ut verba litteras alıa assumant, alıa mittant, alıa commutent...

50 Plato, Crat 394 B [G 2]: 'In the same way, perhaps, the expert of words considers their power, and he is not disconcerted, when a letter is added or transferred or taken away, or when the power of the word finds its expression in completely different letters.', cf. Gentınetta, 1961, 112 sqq

31 Steinthal, $1890^{2}, 1,346$ sqq An edition of Tryphon's fragments has been published by A de Velsen in 1853 (1965). According to others the theory is much older, Barwick, 1957,57

32 According to this theory, words may change by addition (pleonasmós), elision (sunkopè), change (metabolè), or metathesis (tropè) Tryphon uses the term páthè for these phenomena, e.g. frg. 131, pp. 97-8

${ }^{53}$ Tryphon, frg 130, p 97 [G 3], another example, Barwick, 1957, 56-7

54 Bekker, AG, II, 891, quoted by Steinthal, 1890², 1, 311, note [G4] 
with ordinary sound symbolism is that this doctrine of Tryphon does not explain the meaning of a word by means of the sounds of that word, but that it seeks to give an explanation of the change of one form into another in terms of the change in meaning. There is, of course, a certain relationship with the doctrine of the significant value of sounds, as it is found in the Cratylus, in so far as each sound is believed to contribute to the formation of the meaning. ${ }^{55}$ Both doctrines are found in Arabic grammatical works. In Ibn Ginnī’s Hasăäis we find three chapters that deal with the subject of the relations between sounds and meaning: 'Chapter on sounds that follow the meaning', 56 'Chapter on the strength of the sound as corresponding with the strength of the meaning', ${ }^{57}$ 'Chapter on sounds that imitate the meaning'. ${ }^{58}$ Ibn Ginnī says: 'As for the correspondence between the words and those events that are symbolized by their sounds, this is a large subject ..., namely that they (sc. the Arabs) very often make the sounds of the letters correspond to the events expressed by those letters. They treat the events and the letters alike, and they try to imitate the events with the letters'. ${ }^{59}$ Suyūti quotes these remarks about sounds that imitate the meaning of the word, ${ }^{60}$ and in the same context he also deals with the theory of Abbād ibn Sulaimān, according to whom there is a natural relationship (munäsaba tabi $\vec{i} y y a$ ) between words and meanings; ${ }^{61}$ this brings us to the theories conceming the origin of speech and the epistemological value of words.

A good example of the way in which Ibn Ginni's theory about the correspondence between sound and meaning operates is that of the words hadm (to eat) and qadm (to crunch something dry): 'An example of this are the expressions hadm and $q a d m$, because hadm is used for eating fresh herbage ... and gadm for eating something hard and dry ... They chose the letter ' $h$ ' to indicate the softness of the fresh herbage, and the letter ' $q$ ' to indicate the hardness of the dry things, in order to imitate the sounds which are heard when we observe these actions". ${ }^{62}$ Here we are dealing with ordinary sound symbolism, very

ss $\mathrm{Cf}$ Sokrates' remarks concerning the value of the various sounds, Crat. $426 \mathrm{C}$ $427 \mathrm{D}$; cf Steinthal, $1890^{2}, 1,129$

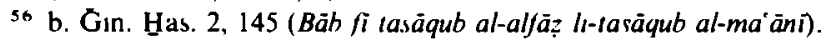

57 Ib. 3, 264 (Bäb fi qun wat al-lafz li-quwwat al-mänā).

so Ib 2, 152 (Bäb fí ımsās al-alfäz ašbäh al-määmi).

s9 Ib, 2, 157, 9-11 [A 7].

60 Suy. Muzh 1, 31-35.

$61 \mathrm{Cl}$ chapter IX, note 65 .

62 b Gin. Has. 2, 157, 13- 158, 2, quoted by Rāzì, Maf 1, 22, 14 sqq (Rāzī mentions his source) [A 8]. 
similar indeed to the remarks made by Sokrates in the Cratylus, but the doctrine is also used for grammatical purposes. In that case we are not comparing two words on the same level, but one primitive, original word, and a secondary form that is derived from it. A good example of this is the explanation of the reduplication of the second radical of a verb as a sign of the repetition of the action expressed by the verb. ${ }^{63}$

It goes without saying that such a theory is founded on the belief that words are not arbitrarily chosen, but that they actually express the essence of the things denoted, in other words, that every word is 'invented' (wudi $a$ ) for a specific reason, and that there is a natural relationship between words and objects. ${ }^{64}$ When a word is changed after the first imposition (awwal al-wad ), this indicates a change in meaning, and this change must be explained, otherwise the change of the sounds could not be justified. Sometimes we find the argument of the 'frequency of use' (katr al-isti'māal) as an explanation of the change of a word, but this argument was not accepted by all grammarians. ${ }^{65}$

The conclusion of our discussion is that Greek grammarians with their etymological theories exercised a certain influence upon their Arabic colleagues, who developed the theory in their own way. Probably the structure of the Arabic language, with its clear-cut patterns, helped the Arabic grammarians considerably in their efforts to build up a system of rules that could explain the changes in sound occurring in actual speech. In building up this system they made use of the principles they had received from Greek grammar. Our thesis is that this influence was already being felt at the time of Sỉbawaihi, in view of the fact that Ibn Ginni mentions alchapters about sounds that imitate the meaning of the word. In the phonetic chapters of Sibawaihi's Kitäb the term mu'tall is already a frequently used technical term, and it is also used by alaccording to one tradition. ${ }^{66}$

The terminology of sound and its relation to meaning is of great interest to a better understanding of the views of Arabic gramma-

\footnotetext{
${ }^{63}$ b. Gin Has $2,155.3 \mathrm{sqq}$

${ }^{64}$ According to Stoic theory, words in the first imposition were imitations of reality, cf. chapter IX

65 Weil, 1913, 11-2 asserts that it is not a Bașrian principle and that the Basrians refused to accept it, but of b. Anb. Ins 173, 7 and al-Halil ap. b. Gin Has 3, 35, 11

${ }^{66}$ Sib. Kit 2, 355; 362; 368 et passım, Wild, 1965, 35, 94
} 
rians, ${ }^{67}$ it also gives us the opportunity to illustrate their relations with the Greek world We will discuss below the opposition mainal laf $z,{ }^{68}$ here we will occupy ourselves with the term saut (sound) and the classification of sounds-not, though, according to their various phonetic properties, but according to their semantic value

First we must consider the Greek data, which we assume to represent to a large degree the Stoic theory According to the Stoics sound is a body, ${ }^{69}$ which comes into being as the result of a percussion of the air: 'Sound is air which is struck, or (it is) what is perceived especially by the ear, as Diogenes the Babylonian says in his treatise about sound' 70 The most important subdivision of sounds was the division into sounds produced by an act of will (1 e human speech), and sounds which are produced instinctively ( 1 e sounds produced by anımals) Only the first group of sounds may receive the attrıbute 'meanıngful' (sèmantıkós) It goes without saying that human speech is always articulated and that it can be written (which in Stoic terminology amounts to the same thing) ${ }^{71}$ Animal sound, on the other hand, is never a carrier of meaning, even though it may be considered articulated at times ${ }^{72}$ Moreover, there are sounds which are produced in the form of meanıngless and unarticulated noises, which cannot be written down (1.e., the sounds proper, produced by inanimate objects): 'The sound of an animal is air which is hit instinctively, (the sound) of a man is articulated and intentionally pushed out, as Diogenes says' 73 'Speech, according to the Stoics, as Diogenes says, is a sound which can be written down, like hèméra (day); language is meaningful sound, which Is intentionally produced. like hèméra esti (it is day) ... Sound differs from speech, because sound may also be a noise, but speech can only be somethıng articulated. Speech differs from language, because language is always meaningful, whereas speech, unlıke language, may also be meaningless, like blituri' ${ }^{74}$

\footnotetext{
${ }^{67} \mathrm{Cf}$ also Loucel, 1963, 263-4, 201-2

${ }^{68} \mathrm{Cf}$ chapter $\mathrm{X}$

69 SVF 2, 140-2, 3, 213, 2, cf scholia D T 181, 4 sqq , SVF 3, 212, 29 sqq

${ }^{70}$ SVF 3, 212, 23-5 [G5], of SVF 2, 138, 139, 142, Sen Quaest nat 2, 6

71 Barwick, 1957, 11, Steinthal, 1890², 1, 291, Diomedes, 2, 413 ed Kell
}

72 Even about the artıculateness of animal sounds there existed some disagreement, cf SVF 2, 135, 2, 734, and Pohlenz, 1939, 194, note 1 The speech of animals formed one of the basic issues in the discussion about the 'inner' and the 'outer' speech (cf chapter X, note 18) Most of the later Stoics conceded that, for instance, parrots do have a voice which can produce drticulated noises, but dccording to Stoic doctrine animals can never communicate a meaning

${ }^{73}$ SVF 3, 212, 25-7 [G 6]

${ }^{74}$ Ib $213,5-21$ [G 7] 
In the scholia on Dionysios Thrax we find a schematic elaboration of this system: 'articulated' is used in the sense of 'meaningful', ${ }^{55}$ and a new category is added, consisting of those sounds which can be written down: 'Let it be known that some sounds are articulated and have a spelling, like our own; some of them are not articulated, nor can they be spelled, like the crackling of a fire or the sound of a falling stone or a piece of wood; some of them are not articulated, but they can be spelled, like imitations (of the sounds) of irrational animals, e.g. brekekéx (sc. the sound of a frog), or koi, the sound of a pig: the sound itself is not articulated, in so far as we do not know what it means, but it does have a spelling, in so far as it can be written down; still other (sounds) are articulated, but they do not have a spelling, such as the sound of whistling: the sound itself is articulated, in so far as we know what it means-for instance "and whistling he gave a sign to the brilliant Diomedes (Hom. K 502)"-, but it has no spelling in so far as we cannot write it down'. ${ }^{76}$ Because of the synonymity of 'articulated' and 'meaningful' there is no place in this classification for the articulated speech of some animals, e.g. parrots, which is meaningless in spite of its articulateness. Imitations of the sounds of animals appear as meaningless sounds with a spelling, which is quite reasonable, when we consider the fact that 'with a spelling' (engrámmatos) only indicates that such and such a sound can be reproduced in writing with normal letters. The category of 'whistling'-i.e. a sound which is articulated, but does not have a spelling - may be explained as a misunderstanding on the part of the scholiast: what he meant to say was that the sound of whistling cannot be reproduced in writing, but that the word which is used to indicate this sound is meaningful; he then confused the two statements, thereby completing his classification.

A similar division of the sounds is adopted by Ammonios, but he uses 'articulated' again with the sense of 'writable', in accordance with the Stoic use. ${ }^{77}$ He says: 'It follows that some sounds are meaningful,

\footnotetext{
${ }^{75}$ Scholia D.T. 181, 23-7.

76 Ib. 18-27 [G 8].

77 Amm. comment. in Aristot. de interpret. 31, 3-5 ed. Busse; also Joh. Dam. D, 5, 1-27; cf. Zirın, 1974, who translates agrámmatos with 'not resolvable into discrete units of speech-sound', identifying the grammata with phonemes. We agree, but have retained the translation 'not having a spelling' in order not to confuse the termınology As a matter of fact, we may safely state that prior to the beginning of phonology only phonemes were used and (implicitly) known; the real discovery of phonology has been that the chain of phonetic events was endless and variable. In order to reestablish a
} 
while they can be written down, like human speech; some sounds are meaningful, though they cannot be written down, like the barking of a dog; other sounds are meaningless, but they can be written down, like the word blituri; still other sounds are meaningless and they cannot be written down, like a whistle which is produced for no reason at all and not for purposes of communication, or like the imitation of the sound of some animal'. ${ }^{78}$ We observe in the first place that Ammonios attributes to dogs a meaningful, though not 'writable' sound, unlike the Stoics, who grant to animals at the utmost an articulated, never a meaningful speech. This is, however, in accordance with the Peripatetic doctrine that animals, too, use their voices to express a meaning. ${ }^{79}$ But when we try to imitate these animal sounds, they remain sounds which cannot be written down, and which, moreover, lose their original meaning. In the second place, we find that Ammonios' primary division is made into meaningful and meaningless sounds. This brings words like blituri into another category than human speech.

The Stoic opinion that sound is a body, is found in the Arabic translation of the Placita Philosophorum. ${ }^{80}$ This materialistic doctrine was taken over by Naz̧zām (d. 231/846), ${ }^{81}$ a Mu'tazilite whose affinity with Stoic philosophy in various respects has been demonstrated by Horowitz. ${ }^{82}$ The Stoic definition of sound as the result of a percussion of the air is found in a number of authors in the Arabic world, who have in common that they used Greek logical and physical theories: Ibn Sīnā, the Ihwān aș-Safă', and 'Abd al-Gabbār. ${ }^{83}$ "Abd al-Gabbār also gives us his ideas about the classification of sounds: 'The principle of this chapter is that sound in general is produced in different ways: it may be produced as sound proper, ${ }^{84}$ not articulated;

sound basis for the study of these events 11 was necessary to formulate exactly and explicitly the operational function of the phoneme It is, of course, absurd to suppose that, prior to modern enlightenment, all grammarians confused letter and sound, $\mathrm{cf}$ Caron, 1947 A very good analysıs of the medideval concept littera in Benediktsson, 1972, 41-86

78 Amm comment in Aristot de interpret 31, 12-6 [G9]

79 Pohlenz, 1939, 191 sqq

so Plac Phıl 277, 17

si Ap Rāzī, Ma广 1, 29, 7

H2 Horowitz, 1903, 1909, 8-33

${ }^{\text {u3 }}$ b Sin ap Rā7ī, Maf 1, 29, 3-4, Rasāil, 3, 123, 10-1, also p. 132, "Abd al-Gabbār, Mugnī, 7, 12, 7-8

84 Correcting tentativel mufid into muqaviad, of below Saut muqavyad should be translated by 'specific sound', muqawad is synonymous with miavyan, of b Anb Ins 103,7 
it may be an articulated sound in general; and it may be articulated, and then either be connected or interrupted; ${ }^{85}$ it may be produced ro form one or more letters, but sometimes it is produced as something which cannot be described thus, for instance the creaking of a door: even though it consists in something with the same nature as some of the letters, it is only recognized as such when the sound is produced in a place with a definite acoustic structure, such as the structure of the mouth. ${ }^{86}$ There is also a remark about the speech of birds: 'Therefore (sc. because it is meaningless), the speech of birds is not called language, even though it consists sometimes in two or more letters in a definite order' ${ }^{87}$

To begin with his last remark about the speech of birds: "Abd al-Gabbar apparently agrees with the Stoics that animals can imitate human speech, and that, therefore, their speech can be written down and is also articulated. ${ }^{88}$ This speech, however, can never be meaningful (mufid), since animals do not possess reason.

The rest of the sounds are divided into sounds proper, which cannot be articulated, and articulated sounds, which may or may not have a spelling. Our emendation of the text seems to be unavoidable, because if language alone is meaningful, and if language consists in letters in a definite order, ${ }^{89}$ and if these letters have to be articulated sounds, then a sound which is not articulated, but does have a meaning, is hardly conceivable. The examples of the two subdivisions of the articulated sounds-those which have a spelling, and those which cannot have one-are the same as in the scholia on Dionysios Thrax: on the one hand we have human speech, which can be written down, and on the other hand we have a sound which as a sound cannot be written down, but as the word which denotes that sound, is articulated, i.e. meaningful. In both cases the misunderstanding arises from the confusion between the sound and the word that denotes it. The expression 'a definite acoustic structure' is matched by the Stoic descriptions of the nature of sound and speech. ${ }^{90}$

H5 For an explanation of these terms Rasā'ıl, 3, 137, sqq

Ho 'Abd dl-Gabbār. Mugnī. 7, 6. 16- 7, 2 [A9]

*7 Ib 6, 14-5 [A 10] The 'specch of birds' (mantrq at-tarr) Qur'ān, 27/16

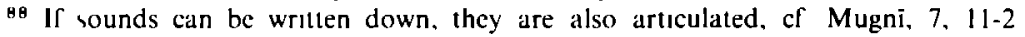

- . (speech) cannot be letters in a definite order. without dt the same tıme being articulated sounds' [A 11$]$

H4 Mugni, 7.6. 11-2.

${ }^{90} \mathrm{Cl}$ SVF $2,44,15-6,2,227,35-7,2,258,32$ sqq 
The classification of sounds that we have discussed here uses the same categories of articulateness and spelling as the Stoic division. There is another division - found in the Rasä'il Inwān aș-Șafä' and in Rāzì's Mafätĭh ${ }^{11}$-, namely into animal and non-animal sounds. In this division there is also a place for interjections, which are classified as those human sounds which cannot be expressed by letters, or as those human sounds which do not convey a meaning. One of the technical meanings of the word saut (sound) is indeed 'interjection'.

Another important resemblance between Greek and Arabic theories is provided by the distinction between 'speech' (léxis) and 'language' (logos) on the level of human speech, which is so characteristic for Stoic linguistics, and which turns out to have been known in the Arabic world. Ibn Ginnī writes: 'As for language (kaläm), this is every self-sufficient expression, which communicates its own meaning. This is what the grammarians call "sentences" (ğumal), such as zaid ahüka (Zaid is your brother), qāma muhammad (Muḥammad stood up) ... As for speech, (qaul), essentially it is every expression which is uttered by the tongue, be it complete or incomplete. Complete speech is communicative - I mean the sentences-..., while incomplete speech is not, such as zaid, muhammad, in (if) ... Every language is speech, but not every speech is language'. ${ }^{92}$

The distinction between complete speech (qaul tämm) and incomplete speech (qaul nāqiṣ) is identical with the Stoic lektà autotelè and lektà ellip $\dot{e}:{ }^{93}$ the similarity in terminology is striking. ${ }^{94}$ The Stoic example of a meaningless word-i.e. a word which is speech, though not language-, blituri occurs in an Arabic source, namely in the notes of al-Hasan ibn Suwār (d. 942/331) on the Arabic translation of Aristotle's Categoriae: here it has the form halanțūr. ${ }^{95}$

The word that we have translated with 'communicative' is mufid; this attribute may be applied only to complete sentences which consist minimally of a verb with its subject. $A$ verb and its subject form a

ฯ1 Rasā'1l, 3, 123-4, Rāzí. Maf 1, 21, 19 sqq

92 b Gin. Has 1, 17, 9-16 [A 12]

93 SVF 2, 58, 29-30, 2, 61, 25-6

94 Ellıpès = näqus; autotelès = mustaqıll $f i$ nafsihı As the exact equivalent for autoteles we regard the term mu/id. which means in our interpretation completing, realızing, of below Mussaqull fi nafsihı is a translation of the Greek term, not a calque

93 Ed Georr, 361 antepen. (the vocalization is hypothetical), cr chapter VI, note 38, and Walzer, $1963^{2}, 72$ 
sentence that is independent and yields meaning ( $f^{\prime}$ ida) ${ }^{96}$. The term $f a^{\prime} i d a$ indicates an independent meaning that is self-sufficient; it is connected with other words from the same radicals ' $f-y-d$ '. The fourth form of the verb, afäda, means 'to do someone a service, to give property to someone', or 'to derive profit from' (in this sense it is synonymous with the tenth form istafäda); the masdar ifäda means 'advantage, usefulness'. Afäda is also a technical term with the sense of 'to transmit something, to express'; it may be said about the transmission of science, an opinion, knowledge, a meaning, ${ }^{97}$ or about the expression of grammatical categories, for instance of the tenses, or of determination. ${ }^{98}$ Goichon translates afäda with 'il donna', and consequently, ifäda with 'don, acquisition': (Ibn Sīnā) 'l'acquisition de l'existence par la nécessité d'être (ifädat al-wuğ̄ud li-wuğ̄üb al-wuğ̄ud). ${ }^{99}$ We believe that in all examples quoted, afada also expresses the actualizing of something potential, the realization or the completion of something.

In the technical vocabulary of 'Abd al-Gabbār, afäda is used for persons: speech is only possible when it is produced by someone who 'talks sense' (yufidu). ${ }^{100} \mathrm{~A}$ similar use is found in grammatical writings, when the verb is used absolutely: this or that word 'imparts a meaning', 'completes the meaning of the utterance' $(y u f i d u)$, for instance when it is said that 'the particle only means something in conjunction with two words' (al-harf lā yufidu illa bi-kalimataini). ${ }^{101}$ In this sense it āda may come very close to maina, for instance when ibn Hišām says that speech consists in two parts: the phonetic expression (lafz), and the semantic function (ifäda). ${ }^{102}$

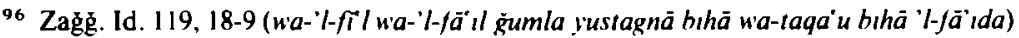

97 Yufidu $\%$ llm (b Anb Lum 33, 2; 34, 2); yufidu \%-zann (1b. 34, I), yufidu ma'rıfa (Far Sarh, 53, 19); vufidu '/-ma'nā (b. Anb. Ins. 72, 7-8, Aš̀arī, Ibāna, 44, 10; Suy Muzh 1, 16, 13: l/ādat al-la/z lil-ma'nā). Ishāq ibn Hunain translates the Greek verb phôtizem with vufidu 'd-dau' (ap Gätje, 1971, 147, 12-6) Cf. van Ess, 1966, 447, $s v$. ("einbringen").

98 Ifädat al-azmma (b Gın. Haș 1. 375, 9); al-ıa'rif (b. Anb Asr 93, 6) Cr Suy Muzh 1, 25, 15-6 the fact that qäma 'n-nās expresses the predication of the standing

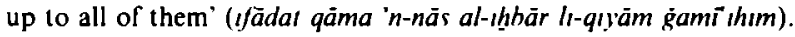

99 Goichon, 1938, 288, s v ifäda We would prefer to translate 'realızation' (c) in the same lemma 'faıre acquérır l'être, donner l'être à une chose qui n'a pas en soi cel être')

100 'Abd al-Gabbār, Mugnī, 7, 6, 14; 7, 9, 16-7, 7, 10, 9 sqq.; 7, 48, 9-10; 7, 63, 18-9;

7, 101, 20-1, 7, 102, 3; 7, 182, 9-12; 7, 183, 16

${ }_{101}$ b Anb Lum. 51, 7-8; cf Zağğ. Iḍ. 55, 1-4

102 b Hiš. Awd. 1, 11, 2-3. 
A sentence which contains everything it needs, a complete sentence, is called mufid: only kaläm can be called mufid, unlike the qaul, which may be gair mufid. ${ }^{103}$ In this sense, mufid is equivalent to the Greek term autoteles, which is used to indicate the quality that separates léxis from lógos. The literal meaning of autoteles is something like 'self-accomplished, complete in itself, realized by itself ${ }^{104}$ The product of a mufid sentence coming from a mufid person, or, in other terms, the result of the process of ifäda is the fálida. Fa'ida is the meaning of the sentence, which can only be conveyed by a complete sentence, not by a string of loose words. Completeness should be understood in this context as syntactic completeness: the verb and the agent are the minimum constituents of an independent sentence that makes a complete sense. ${ }^{105}$ In Greek grammar this complete meaning is called autotéleia. $^{106}$

The tenth form of the verb, istafada, means 'to receive, to acquire', for instance "with the " $m$ " and the $w \bar{a} w$ of the form maf "ül you obtain a specific meaning (tastafidu bi-mim maf ül wa-wāwihi mainan mahsșusan). ${ }^{107}$ The meaning resulting from this is mustatäd (realized, acquired, complete). Goichon translates 'c'est ce qui est donné par le mufid et acquis par le mustafid' ${ }^{108}$ It indicates what is received from outside, and what completes and realizes a potential quality: (Ibn Sinnā) 'things imagined by the mind, under the influence of something from outside' (umür tuṣuwwirat fi 'd-dihn mustafäda min h̆äriğ). ${ }^{109}$ We may also refer to a technical term in Islamic psychology "aql mustafäd, i.e. ho thirathen noûs: the aql hayūlāi in so far as it is realized by the aql fa" $a l$, that is, by a factor not coming from itself, but from outside. ${ }^{110}$

${ }^{103} \mathrm{Cf}$. above, note 93

104 Dion. Thr 22, 4-5; SVF 2,166, 2, 181, 2, 187; a synonym of autorelès is téleros. cf. also Donnet, 1967, 150-3

${ }^{105} \mathrm{Cr}$. Zağg. Id. 119, 17- 120, 4, and below, chapter VII, note 101. Lane. s.v., translates fä'ıda with "utılity as expressive of a meaning, or as contributing to the expression there of ; meaning, import, complete meaning'.

106 Donnet, 1967, 150-3

107 b Gin Has 2, 481, 13-4; cf Suy Muzh. 1, 25, 19; b. Gin. Has. 1, 300, I: yustafädu mainan (a meaning is obtained).

108 Goichon, 1938, 289, s v mustafäd.

109 Goichon, 1938, 290.

110 Hwār Maf. 135, 2, cf. Hunain b. Ishāq's translation ap. Badawī, 1971, 35, 4; cf 16 pp. 36-7 with Alexandros of Aphrodisias' treatise Peri noú, Scripta Minora, 1, 106-113, ed. Bruns, Berlin, 1887, (or the psychological theorıes: Gätje, 1965, 277. Finnegan, 1957, discusses the connection between mustafäd and the Greek term epiktètos, pp. 147-8. 
We believe that ' $\mathrm{f}-\mathrm{y}-\mathrm{d}$ ' is equivalent to the meanings espressed by the Greek verb telein; the Arabic root is singularly suited for the translation of the Greek verb, since both verbs indicate a relation of giving, paying, as well as a completion, a realization. Probably the first term to be used in this context in the Arabic world was mufid as the translation of autoteles (or téleios). The philosophical terms mustafäd, afăda etc. must be a later development. It is interesting that télos in the sense of 'use, aim, goal' of a science is translated with fä'ida. ${ }^{11}$

Another trace of the Stoic theory about the logos is found in observations about the development of speech and reason-in Stoic terminology translated both by the word logos. Jamblichos tells us that according to the Stoics the logos is not immediately realized at the time of birth, but that it takes fourteen years to build it up. ${ }^{112}$ The number of fourteen years is mentioned by Diogenes the Babylonian in his definition of language "which is completed after fourteen years'. ${ }^{13}$ A number of seven years is given in the Placila Philosophorum in the chapter about the question 'How do perception, insight, and the internal logos come into being?'. 14 The answer is that the internal logos is formed in the course of seven years, which is evidently the first phase of a process that results in the possession of both inner and outer logos (i.e. both reason and speech). This passage in the Placita Philosophorum, or rather its translation by Qusțā ibn Lūqā ${ }^{115}$ may have been the source for Gazzālí ${ }^{116}$ and Rāzí, ${ }^{117}$ who mention the same division of human life into periods of seven years. ${ }^{18}$

${ }^{111} \mathrm{C}$. below, chapter VII, note 18 .

112 SVF 2, 835, cf. also Zenon, SVF 1, 149

113 Diog Laert. 7, $55=$ SVF 3, 212, 27-8 A number of fourteen years, necessary for the maturing of the mind, is mentioned by Poseidonios, a later Stoic ( $\pm 150 \mathrm{~A} \mathrm{D}$ ), according to a quotation by Galenos (de afT. dign 8.3 (p 29.9 de Boer = p. 41, $10 \mathrm{~K}$ ), cf Walzer, $1963^{2}, 162$

114 SVF 2, 83, for the term endiathests, of Pohlenz, 1939, 193, and chapter X, note 18

115 Plac. Phil. 71, 17. Daiber's translation 'Woche' is to be corrected into 'Hebdomade' according to the data given here.

116 Gazz Ihyā, 4, 9, 1 11; Munqı̣, 41, 15, ed. Iransl. F Jabre, Beyrouth, 1959.

117 Rāzī, Maf in sūra 12/22, p 111, 5 sqq

11 A Also van den Bergh, 1954, 198-9 


\section{THE THEORY OF GRAMMATICAL CATEGORIES}

'Chıldren should know in the first place how to decline nouns and verbs, for otherwise it is impossible for them to reach an understanding of the rest ${ }^{\circ}$

\section{A. THE PARTS OF SPEECH AND SIBAWAIHI'S DIVISION}

At first sight the division into three parts of speech (aqsäm al-kaläm) in Arabic grammar seems to be a blueprint of the Aristotelian division into noun (ónoma), verb (rhèma), and particle (síndesmos). This was already suggested by Merx, but he pointed out the resemblance to Aristotle and Greek logic exclusively, without taking into account Greek grammar. ${ }^{2}$ While it is true that there is an undeniable superficial parallelism between the Aristotelian and the Arabic tripartition -a parallelism noticed by Arabic authors as well ${ }^{3}$-it cannot be denied that there is a great difference between the Aristotelian logical division and the Arabic grammatical division, especially when we consider the fact that the Aristotelian terms did not denote parts of speech, but rather constituent parts of sentences. ${ }^{4}$

Merx accepted the identification of the three Arabic parts of speech, ism, $f i^{\circ} l$, and harf, with the Aristotelian onoma, rhèma, and sündesmos without any reserve, but this was rejected by Weiß. ${ }^{5}$ According to him harf is a non-technical notion (i.e., it is used for every word that is neither noun nor verb), whereas súndesmos is something specific, namely a word which binds together other words and phrases. ${ }^{6}$ There

1 Quint instıt. orat. 1, 4, 22 (nomina declinare el verba in primis pueri sciant neque entm altter pervenire ad intellectum sequentium possunt)

2 Merx, 1889, 141-3.

3 Cr. Hwār Maf. 145, 9 sqq.; kalıma and ribät are called by the grammarıans $(\hat{i} \mid$ and harf al-mainā, adā respectıvely; Far Iḥs. 34, 4-7. the Arabıc parts of speech, $ı s m, f i l$, harf are called by the Greek (sıc') grammarians ism, kalıma, adāt

4 Weiß, 1910, 379 sqq.; on the nature of the Arıstotelian division Koller, 1958, 28-9; Larkin, 1971, 27-33

5 We1B, 1910, 379 sqq.

6 On the súndesmos in Aristotle's writings: Gallavotti, 1954. The definıtion, poet 1456 b $38-1457$ a 6 , is completely corrupted, but the examples show that the sundesmos has a specific function, namely that of linkıng words and phrases, as is suggested by 
did exist in the Arabic world a logical triad which correlated with the Aristotelian 'parts of speech', namely ism, kalima, ribät, for instance

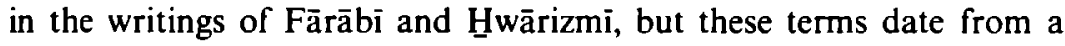
later time. Weiß is right in saying that the Arabic grammatical division was anterior to the introduction of logic into the Arabic world, so that the latter cannot have been imitated by the former: 'Die Auffassung, als gingen bei den Arabern die Anfänge der Logik denen der Grammatik voraus ist ein Hysteronproteron, das die Folge der historischen Tatsachen auf den Kopf stellt'. ${ }^{7}$ We must add, though, that although the logical division became known to the Arabs at a later time, it could have influenced Arabic grammar through Greek grammatical theory, which often betrays the traces of logical influence. For most Greek grammarians the study of language was identical with the study of the nouns and the verbs, while the rest of the words were considered not essential for the sentence, and therefore, not for grammar. ${ }^{8}$ In this respect, they undoubtedly followed the tradition initiated by Aristotle.

Sibawaihi begins his 'Kitāb' with the words 'Words are noun, verb, or particle with a meaning that is neither noun nor verb'. 9 The term ism does not receive any definition, but three examples are given: rağul (man), faras (horse), hä'it (wall). ${ }^{10}$ It is a well-known fact that the analysis of paradigms is very important for the history of Greek and Latin linguistics, not only because in giving examples grammarians tended to use their own names or those of their teachers, but also because the recurrent use of the same examples often helps to

Its name. Cf. Pohlenz, 1939, 161-3; Steinthal, 1891², 2, 263 sqq.; Gudemann, RE, VII, 2, 1780-1811, s.v. Grammatik; Morpurgo-Tagliabue, 1967, 43-58

7 We1B, 1910, 381.

8 On the opinion of the Latin grammarians in this respect: Gluck, 1967, 29-30

9 Sib. Kit. 1, 2, 1 [A 13]. Usually the word kalım (words) is explained as a collective indicating the material from which the kaläm (speech) is made (ism al-g̈ $ı n s$, ism aḍ-där; cf Sïr. in marg, Sib Kit. 1, 2; b. Mal. Alr. vss. 8-9; b Hıš. Awḍ 1, 11, 9-12) A single word is called kalıma, which is defined as "a sound which indicates a single, conventional meaning' (Zam. Muf 4, 14 al-lafżat ad-dälla 'alä ma'nan mufradın bi-' $l$ wad ). The regular plural of kalıma is, of course, kalimät. The difference between kalım and kalōm is that the latter always possesses a complete meaning $\left(\bar{a}^{\prime} \cdot \mathbf{d} a\right)$, whereas the former does not necessarily possess such a meaning, cf. b. His Awd. 1, 12, 1-6.

10 The word $h \bar{a}$ 'i i is left out in Zağgăăğì's quotation of the 'definition', Iḍ., 49, 9-10 As far as I know, 'wall' is not used in Greek grammatical literature, except for the famous example of solotkismós: perıpatón egô ho toîchos épese (while I was walkıng the wall fell down); according to Donnet, 1967, 250-1, this was the standard example of the grammarians; cf. his reference to Johannes Glykas, Johannis Glycae opus de vera syntaxeos ratione. Ed. A. Jahn. Bern, 1848, 35, 15 sqq. 
establish links between different groups of grammarians. ${ }^{11}$ The field of Arabic grammar lies almost barren in this respect. It is, therefore, rather significant that Sibawaihi uses the two words rağul and faras as examples of nouns. Barwick already observed that when these two examples occur in Greek or Latin grammar (ánthrôpos/hippos, and homo/equus, respectively) they spring from Stoic tradition. ${ }^{12} \mathrm{We}$ do not believe that the occurrence of the same two words 'man' and 'horse' in Arabic grammatical literature is a coincidence, and we think that by his use of precisely these two substantives-the origin of the third one, $h \bar{a} ' i t$, remains unclear-Sibawaihi followed a very old tradition, a tradition even older than the examples cited by Barwick, since the very same words are already used by Plato and Aristotle. ${ }^{13}$ of course, Sibawaihi's source could not have been the Aristotelian tradition, since he lived before the introduction of Greek logic into the Arabic world, but he was dependent on the tradition of the schools, as reflected in Dionysios Thrax' Téchnè, which in its turn was dependent on the Stoics. Incidentally, Dionysios' third example, lithos (stone), was also among the popular examples of Arabic grammarians, but in this case Aristotle may have been the source. It is true that later grammarians who continued to use Sibawaihi's first two examples may have borrowed them from the by then already existing translations of the works of Aristotle, but it is certainly more obvious to attribute them to the enormous influence of the Kitäb.

Among later grammarians who used rağul (or insān) and faras are Zağğāğì, ${ }^{14}$ Mubarrad, ${ }^{15}$ Ibn Kaisān, ${ }^{16}$ Abū 'Ubaid, ${ }^{17}$ Ibn Ginnī, ${ }^{18}$

11 For the use of one's own name or the name of one's teacher. cf Barwick. 1922, 93 and note 2, 173 As a typical example we may mention Apollonios' use of the name truphôn, the name diogénes in the Téchne of Diogenes of Babylon, the names diôn and dioklès in Diogenes Laertıos, 7, 56 sqq Cf however Schmidt, 1839, 66, n 91, last paragraph For the tradition of the paradigms Barwick, 1922, 93, 1957, passim, Donnet, 1967, 294-6

12 Barwick, 1957, 8, n 1 'Die beiden Substantiven (sc homo, equus in Augustınus' De Dialectica) stammen dus stoischer Tradition. Diogenes v Bab (SVF III, 213, 29) nennt ebenfalls "Mensch" und "Plerd", anthropos und hippos als Beispiele', cf Dion Thr 24, 5

13 Plato. Alc I, 111 D, Arıstot categ I b 28 et passim, of also Antusthenes in discussion with Plato ap Simpl in Aristot categ 208, 28 ed Kalbfleisch (hippos)

14 Zağğ Id 100,6 , Gum 17,8

is Mub ap Zağğ Id 51,2 (quoted from the beginning of the Muqtadab), of Zağg Id 100,6

16 b Kals ap Zaǵğ Id 50, 13. cf below, chapter III B, note 23

17 Abū Ubaid ap Suy Muzh I, 191, 4

18 b Gin Has 2, 206, 9 
Ibn al-Anbāri, ${ }^{19}$ to name but a few. Even outside grammar we find the same two nouns being used as examples, for instance by a theologian such as al-Ašari, ${ }^{20}$ and by two philosophers, al-Fārābi ${ }^{21}$ and Ibn Sinnā. ${ }^{22}$ In the case of al-Ašarī the use of insān and faras may be ascribed either to his knowledge of Sibawaihi's Kitäb, or to his use of the commentaries on the Aristotelian writings, which, under Stoic influence perhaps, use ánthrôpos and hippos. ${ }^{23}$ The same holds true for Ibn Sīnā. With al-Fārābi there is also the possibility of influence by Greek grammar. ${ }^{24}$

Sibawaihi's words 'As for the verbs they are patterns taken from the expression of the events of the nouns, and they are constructed to (signify) what is past, and what is to come, and what is being without interruption' $^{25}$ have often been taken as a definition of the verb. ${ }^{26}$ But when we understand the term $m a^{\prime} h \bar{u} d$ in the sense of 'etymologically derived from', we find that it is an assertion that the masdars are etymologically prior to the verb. Merx thought that there is a connection between this assertion and a passage from Aristotle, where the same thing seems to be stated in slightly different words. ${ }^{27}$ There is, however, no need to look for a connection in the commentaries on Aristotle, if we take into account the data furnished by the Greek grammarians, as we will see below in the discussion concerning the priority of the masdar. ${ }^{28}$

Another problem is the interpretation of the words "the events of the nouns' (ahdāı al-asmā'). According to Zağğāăği we must understand by 'nouns' 'the owners of the nouns' (așhäb al-asmä'), i.e., the real persons who perform the actions, and who are the nominata of the

19 b Anb Ins 102, 17, Asr 16, 17

20 Ašaari, Ibāna, 21, 24-5 Aš arī uses insān wa-faras instead of rağul wa-faras

2 Far lhs 11 ulı - 12, I (msän wa-faras), Fārābì also uses Sỉbawaıhı's examples for the personal names zaid na-'amr

22 van den Bergh. 1954. 2, 130

23 See Aristot caleg 1 b 28

$24 \mathrm{Cf}$ below

25 Sib Kit 1, 2. 2-3 [A 14].

20 These words are also quoted by Rāzi, Maf. 1, 36, 7-8

27 Merx, 1889, 142. cf Gatje, 1971, 5-6 It really does nol seem very probable that Aristotle meant an etymological derivation of the verb from the noun when he says (de interpret 16 b 8 sqq) 'I say that it also signifies time (sc the verb), such as "health" (hugieia) is a noun, but "is healthy" (hugiainet) is a verb, because It also signifies the present occurrence, and it is always a sign of those things which are said about something else' [G 10]

${ }^{2 \mathrm{H}} \mathrm{Cf}$ below, chapter III $\mathrm{C}$ 
nouns. ${ }^{29}$ This interpretation is criticized by Bāqillānì: according to him such an interpretation is only allowed when there is sufficient proof to alter the manifest meaning (zähir) of the words. In the present case, it is perfectly right to interpret Sibawaihi's words as an implicit statement that nouns are identical with their nominata. ${ }^{30}$ 'Events of the nouns' are thus identical with 'events of the persons' (ahdä! al-ašh̆ạss).

Concerning the paradigms of the nouns, rağul and faras, we can have no absolute certainty whether their origin must be sought in the translation of the commentaries on Aristotle, or in direct contact with Greek grammar. The most frequently used paradigm for the verbs, however, hardly leaves any room for such doubts. The Greek verb tuptein (to hit) was never used by Aristotle, or by his commentators, whereas in grammar it was the most popular example for the category of the verbs. ${ }^{31}$

Throughout antiquity tuptein remained the most popular and the most frequently used verbal paradigm. Theodosios used its conjugation as an example in his treatment of the verb-which means that it was used in the schools. We come across tiptein-sometimes together with gráphein (to write) and poiein (to do)-in almost every work of Greek grammar. ${ }^{32}$ It is hardly surprising then that this verb, translated into Arabic as daraba should have been borrowed by the Arabic grammarians, if they really were dependent on the contact with living grammar in the Hellenistic countries. Since Aristotle uses other paradigms, e.g. hugiainein (to be healthy) and badizein (to walk), we cannot but attribute Sibawaihi's use of daraba to the influence of living Greek grammar. ${ }^{33}$ Note that kataba (to write) and facala (to do) are also frequently used.

${ }^{29}$ Sähıb al-ısm is in Zağğāăī’s terminology synonymous with musammā, Id. 56, 5 , $82,3: 83,4$

30 Bāq Tamh 228, 17-229, 7.

"A few examples. Dion Thr 49, 1 (hiptem, potein, gráphem), 54, 2; 55, 1 (gráphèm, légein), Greg Cor 95 (ruptem, porein), Barwick (1922. 93, n 3) supposes that graphem and légem stem from the Stoic tradition, cf Diog Laert. 7, 58, from the Stoic Téchnè of Diogenes of Babylon. Note that the verb lége'm in tts Arabic translation qaala was less appropriate because of its weak medial radical, still. it is often used as an example of this class of verbs

${ }^{12} \mathrm{Cf}$ Uhlig's amusing note in his introduction to the Téchne of Dionysios Thrax. LIII, 16-25, where he also draws the attention to the fact that the Syriac and Armenian translations use the verb 'to hit'

${ }^{33}$ Sib KII (a few examples chosen at random) I, I, 14, I, 2, 6, I, 4, 4, I, 14, 10; $1,24,4,1.55,12,1,66,5$ sqq. . 1, 82, 9 sqq. . 1. 87, 7-8, 1. 93, 3 sqq , 1, 100, 8-9: 1. 103, 10, 1, 211,8 sqq : I, 278, 16: 1, 386, 7: 1, 407, 10:1. 433, I1, cf. also Sib ap. b Fār Sàh 49. II sqq 
Owing to the enormous influence of Sibawaihi's Kitäb daraba remained in use with later grammatical writers; these include: Māzinī, ${ }^{34}$ Mubarrad, ${ }^{35}$ Zağğāḡì, ${ }^{36}$ Sirāfi, ${ }^{37}$ Ibn Ginnī, ${ }^{38}$ Ibn al-Anbārì, ${ }^{39}$ Zamahsšari.$^{40}$ The same verb is used also in logical writings, mainly in a grammatical context, for instance with $\underline{H}$ wărizmīi ${ }^{41}$ and with $\mathrm{R} \overline{\mathbf{a} z i},{ }^{42}$ but there are also instances where it is used in purely logical texts, for instance by Gazzālī ${ }^{43}$ and by Ibn al-'Assāl (1st half of the 13th/7th century). ${ }^{44}$ This shows that whatever may have been the influence of the Corpus Aristotelicum on Arabic logic and grammar. Sibawaihi's influence as the author of the Kitäb surpassed it in such things as the choice of a paradigm.

The interpretation of Sibawaihi's definition of the third part of speech harf $\dot{g} a \bar{a}^{\prime} a$ li-ma'nan laisa bi-'sm wa-lā $f i^{i} l^{45}$ is essential for the understanding of the Arabic doctrine of the parts of speech. The first translation into a European language was given by de Sacy: '(et la lettre) employée pour exprimer un sens et qui n'est ni nom, ni verbe'. ${ }^{46}$ According to this translation the particle is a part of speech with a special meaning, just as nouns and verbs have their special meanings. Merx tried to fit Sibawaihi's words into his conception of an Aristotelian division of the Arabic parts of speech, and was therefore forced to regard the third part of speech as a category without a meaning of its own, since according to Aristotle the sundesmos is a meaningless sound (phônè ásèmos) ${ }^{47}$ This resulted in the translation: 'particula sive littera, quae ad sensum aliquem accedit', ${ }^{48}$ i.e., the particle serves to indicate a meaning in another word. Similarly we Find with Jahn: '... um (den Nominibus und Verbis) Sinnstellungen zu geben (welche sie sonst nicht haben), ohne selbst Nomina und Verba

34 Maz. ap. Zağğ Mağ $81: 88$

35 Mub ap. Zağğ Mağ 219, 15: ap Zağğ Id 136, 7 sqq.

36 Zağğ. Iḍ. 56 , ult : 59, 8, 60, 1, 61, 3, 62, 3, 64, pen.; 65. 9, 12; 72, 13 etc

${ }^{37}$ Sìr ap Tauh Muq. 175, 20 sqq.

38 b. Gin Has $1.375,12,1,379,5,2,44,5$ elc

39 b. Anb Ins 2,17

40 Zam Mur. 126, 10

41 Hwār. Maf 42, 15

42 Ràzí, Maf 1, 33, 4; for hıs use of the example. cl the quotation from Sibawaıhı ap b Fār Sāḥ 49,11 sqq

43 Gazz. Maq. 10, 13

44 Cr Rescher, 1966, 117.

45 Sib Kit 1, 2, 1.

46 de Sacy, 1829, 361, cf 385.

47 Aristol poet cap 20,1456 b 38 .

48 Merx, 1889. 142-3. 
zu sein' ${ }^{49}$ This interpretation is correct according to the definitions of the particle given by later grammarians, for instance by Zağğăği 'particle is whatever signifies a meaning in another word' (mā dalla ala mainan $f i$ gairihi), ${ }^{50}$ which assign to the particle the function of modifying the meaning of another word in the sentence. ${ }^{51}$

We agree with Wei $B^{52}$ that Sibawaihi's words, interpreted in this way, are in conformity with the interpretations of later grammarians, but that they do not represent Sibawaihi's own conception of the particle. In the first place, the words laisa bi-'sm wa-la ficl cannot belong as a second attribute to the word harf--which would be a highly unusual construction-, but they determine the word mainan. ${ }^{53}$ In the second place, these words would be completely redundant, if we were to follow Merx and Jahn in interpreting ğa $\vec{a} a$ li-mainan as 'gives a meaning in another word', since in that case the particles would have been defined sufficiently as something different from the nouns and the verbs, which do have a meaning of their own. In the third place, it is difficult to imagine that Sibawaihi should have left out words to the effect that this mana is found in other words. For these reasons Weiß translates '3. Harfe, die zum Ausdruck für etwas gemeintes stehen, das nicht Name (d.h. Ding) und nicht Aktion ist'. ${ }^{54}$ In other words $\dot{g} \bar{a} ' a$ li-mainan does not distinguish the particles from the nouns and the

49 Jahn, I, 1, I Cr also Gatje, 1971, 6-7, who apparently believes that Jahn and de Sacy had the same idea about the semantic function of the particles. At least, that is what appears from Gätje's words about later Greck theorıes, which assign to the sindesmo a certain meaning. ' $\mathrm{DaB}$ man den súndesmot eine semantische Funktion zuerkennt, würde in jedem Falle auch zur Auslegung Sibawaihs durch de Sacy und Jahn passen'.

5o Zağğ Iḍ $54,12-3$.

${ }^{51} \mathrm{Cf}$ also b Anb Inș. $72,7-8$ the partıcle is only used in order to communicate a

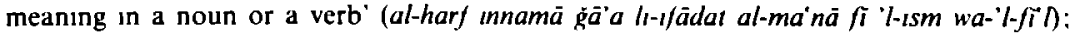
Mub ap. Zağğ Mağ 222, $11:^{\prime} \ldots$ it is like a particle of meanıng, whıch is dependent on another word' ( kānat ha-harf al-mainà alladi huwa muiallaq bi-gairihı), Gazz. Miyār. 43, 1 '(the partıcle) is what does not signify a meanıng, unless it is combıned

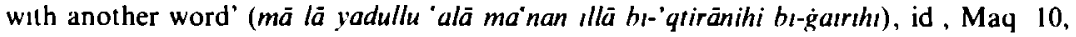
$10-5$

52 We1B, 1910, 375-9.

53 Sibawaihı uses $1 \mathrm{sm}$ in the sense of musammā, which explains how he can say about a ma'nä that it is neither a noun nor a verb, cf. Weiß, ib. 376-7 and e g. Zağge. Id 56, 3-6 There is, though, a note in the margin of the manuscript used by de Sacy, which says (de Sacy, 1829,385 ). 'And (the words) lassa bi-'sm wa-lā $\hat{f} l$ are an attribute to harf, not to ma'nan, as some people believed. This is proved by his (sc. Sibawaihi's)

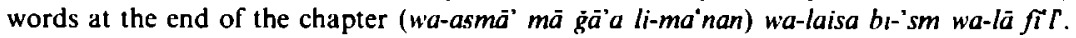
(cf. Sib. Kit. 1, 2, 6-7) [A IS]. The same argument is used by Diem, 1970, 322; cf. also Mosel, 1975, 217.

$54 \mathrm{We} B, 1910,376$ 
verbs, but from other particles without a meaning, i.e., the hurüf in the sense of 'letters, syllables'. We may compare with this the expression al-Ah_laš uses when he speaks about the word mundu (since): hiya harf manan laisa bi-'sm. ${ }^{55}$ Here the category of the hurüf with a meaning of their own is designated with the term 'meaningful particle' (harf ma'nan). We may also refer to Zağğāğī's category of the hurūf al$m a^{i} \bar{a} n \bar{i}$ as against the hurūf as letters and as parts of words. ${ }^{56}$ Hwāriz$\mathrm{mi}$ informs us that the Aristotelian rihat $\bar{a} \bar{t}=$ siindesmo $i$ are called by the Arabic grammarians hurüf al-ma äni. ${ }^{57}$ That particles contribute to the meaning of the sentence with their own meaning is already stated in "Alī's' definition 'a particle is what communicates a meaning' ${ }^{58}$ This interpretation seems to be preferable to the one given by Diem, ${ }^{59}$ who takes ğa'a li-mainan and laisa bi-'sm wa-lā fi'l as two 'parallele asyndetische Relativsätze'. According to Diem $\grave{g} a a^{\prime} a$ li-ma'nan indicates the function of the harf, namely having a meaning, as against the nouns and the verbs, which denote a thing and an action, respectively. ${ }^{60}$

The question remains how the words $\check{g} \bar{a}^{\prime} a$ li-mainan are to be translated. Merx' criticism of de Sacy's translation 'employée pour exprimir un sens-according to Merx this should have been $b i$ manan-is invalidated by the loci cited by Weiß, where the same words are used in the unambiguous sense of 'meaningful', 'giving a meaning', ${ }^{61}$ which seems to be the correct interpretation of Sibawaihi's words.

ss Aḥfaš ap. Zağğg. Amālì, 92, 1, l (c⿱ Weıß, 1910, 379)

56 Zağğ Iḍ 54, 12 sqq

${ }^{57} \mathrm{Hwār}$ Maf 145, 13-4, cf also Far Alf 42, 7-8 'To the meanıngful words belong those words which are called by the grammarians hurüf, and which are used to signily a meaning' [A 16]

${ }^{58}$ Ap b Anb Nuzha, 4, 10-1 in a varıa lecrlo which has gäa li-mainan instead of afãda mänan. Cr. also b. Fār. Sāh 53, 6-8 'Arabıc grammarians dıscussed this very often (sc the nature of the harf), but the nearest thing to the truth is what Sibawahı said, namely, that it is that which expresses a meaning which is neither a noun nor a verb. Like when we say zaid muntalig (Zaid is leaving), and then we say hal zaid muntalıq (is Zaid leaving?): with the word hal we express a meaning which is neither present in zaid, nor in muntaliq' [A 17] $\mathrm{Cr}$ Carter, 1972, 85' the particle possesses a certain meaning, but its function is not specified.

59 Diem. 1970, 321-2.

60 Diem, 1970, 316-7

61 Merx, 1889, 142, n 2; Weiß, 1910, 378; cf. Sib. Kit 2, 328, $11,2,473,22,2,172$, 4; cf. also above, note 51 (b. Anb.. lı-lfädat al-mainä) In his commentary on Sïbawaihı's words Sīrāfĩ says (Sarh, 1, 7, quoted by Mubārak in his editıon of the Idāh, p 54, n. 3). 'And if someone were to ask. why did he say harf $\dot{g} \vec{a}$ 'a li-ma'nan, yet we all know that nouns and verbs are meaningful as well (g̈ina li-ma'änın)? ...' [A 18] 
Several philosophical sources demonstrate the fact that a connection was felt between the grammatical harf (together with $ı \mathrm{sm}$ and $f i^{\circ} l$ ) and the philosophical ribàt or rābit (together with ism and kalima), for instance in the remarks made by Fārābi, ${ }^{62}$ Hōārizmī, ${ }^{63}$ and Gābir ibn Hayyān, ${ }^{64}$ and also in Zağgaăğì's conspicuous use of the word ribă! in his explanation of the term harf. ${ }^{65}$ Ribă! may be regarded as a calque of the Greek (Aristotelian) sindesmos. ${ }^{66}$

For the original meaning of harf we should turn to Sibawaihi. In the Kitäb the harf is the third part of speech, with a meaning of its own. Sibawaihi wished to express the fact that the hurüf have their own meaning in order to distinguish them from another kind of hurüf, namely the letters. Hurüf in the sense of 'letters, sounds' are divided by Zağğăği into two groups: in the first place, they are the hurüf al$m u^{\prime}$ gam, i.e., the sounds of the alphabet, which constitute the elementary material for all languages. But these hurüf may also be regarded as the elements of the words, e.g., the "ain in the word gafar, or the $d \bar{a} d$ in the word daraha, i.e., as the letters of these words. ${ }^{67}$ This corresponds to the Greek distinction between the stoicheion and the charakter tou stoicheiou, a distinction that is made by Diogenes of Babylon, by Sextus Empiricus, and by Ammonios in his commentary on Aristotle's De Interpretatione. ${ }^{68}$ In the translations of Aristotle's writings stoicheion is first transcribed as ustuquss, - under the influence of Syriac ustuqsā = Greek stichos, contaminated with Syriac us!uqyā = Greek stoicheion-but this transcription was soon replaced by the term harf, which is very near to stoicheion in meaning: both words

62 Far Sarh, 54, 8-9: rābu! is called by the grammarians harf.

${ }^{63}$ Hwār. Maf. 145, 13-4: ribāı is called by the grammarıans harf.

64 Gäbir ap. Kraus, 1942, 2, 250 : in grammar we have $i s m, f{ }^{\circ} /$, harf; philosophers (ahl al-kaläm al-gauhari) use to call these parts of speech ısm, kalıma, ribät (unites two nouns) / șla (unites a noun and a verb), cf. above, note 3.

6s Zağg Iḍ. 44, 11 : the partıcle is a tie (ribät) between noun and verb

${ }^{66} \mathrm{E}$ g. in the translations of Aristotle's Poetıca: Ibn Sīnā, Si'r, 191, 15 (= wāsila); Mattā ıbn Yūnus, Sı'r, 127, 9 (dıstınguıshed from wäsıla =arıhron, ib 127, 12); lbn Rušd, 235, 20 (distınguished from fäṣıla = árıhron, ib. 235, 24); cf. Fischer, 1964, 148. For wäșila, cf. below.

67 Zağğ. Ị̇. pp. 54-5.

68 Diog. Bab. ap Diog. Laert. 7, 56; Sext. Emp. adv. math. 1, 99; Ammon. comment. in Aristot. de interpret. ed Busse, 23. 17 sqq ; cf. Barwick, 1922, 102 and note 1; Schmidt, 1839, 19, n. 32 Bravmann, 1934, 7-8, refers to a definition in the Rasä'il Ihwän aș $S a f \bar{a}^{\prime}$, where a distinclion is made between three meanings of harf: a mental, a phonetic, and a graphıc meanıng (Rasāil, 1, 311, 16); cf Fischer, 1964, 145; scholia D.T. 317,$32 ; 326,7-8$. 
indicate the smallest part of something, an element, a little piece. ${ }^{69}$ In order to distinguish them from the meaningful hurüf these elements are also called hurūf al-mu 'ğam. ${ }^{70}$

The second category of hurüf is called hurüf al-ma'äni: they are distinguished from the hurüf in the sense of 'letters, consonants' by the fact that they are meaningful. According to Weiß the meaning of harf as a member of the second category is not yet restricted to the technical meaning of 'particle': 'Hier ist nun zunächst festzustellen, $\mathrm{da} B$ bei Sỉbaweihi noch kein Ansatz für diesen Sprachgebrauch vorhanden ist. Nie bedeutet harf bei ihm schlechtweg "Partikel"; wo er wirklich den dritten Redeteil als solchen bezeichnen will, bedient er sich umständlicher Umschreibungen, in denen oft das Wort harf nicht einmal vorkommt'. ${ }^{71}$ Very frequently Sibawaihi uses harf in the sense of 'word', 'phrase', 'combination of words', or generally 'small component of the sentence'. ${ }^{72}$ This is also confirmed by Zamahšarì's warning that the ancient grammarians often used harf with the meaning of kalima (word). ${ }^{73}$ The Greek term stoicheion, which we have met above as the prototype for the Arabic harf = 'letter', is also used in expressions where its meaning seems to be rather close to the term 'word', as for instance with Apollonios Dyskolos: the meaning that corresponds to each word is as it were a component of the sentence (stoicheion tôे lógou) ${ }^{74}$ sometimes a sentence lacks an element (stoicheion), e.g. a preposition. ${ }^{75}$ But the most frequent meaning of stoicheion-apart from the meaning 'letter'-is that of 'part of speech': in the scholia on Dionysios Thrax' Téchnè it is stated that the philosophers call stoicheia what is called in grammar meré tôे logou; ${ }^{76}$ doubtlessly this use of stoicheion was also known in other grammatical writings. The Arabic word harf was an ideal calque of the Greek

${ }^{69}$ Fischer, 1964, 142; Weiß, 1910, 369 sqq ; ustuquss. e.g. Mattā ibn Yūnus, Badawi, 1953, 126, 5

${ }^{70} \mathrm{We1B}, 1910,375$

71 Id. ib.

72 Id. ib 361 sqq.

${ }^{73}$ Zam. Kaššăf, 1, 61, 10.

74 Apoll. Dysk synt 2,11.

79 Ib. $5,14$.

${ }^{76}$ Scholı D.T. 514, 35; Chrysippos, SVF 2, 45, 11; Apoll. Dysk synt. 7, 12; 449, 2. The classic study about the meanıng of storcheion is Diels, 1899. Cf. also: Balázs, 1965. Accordıng to Balazs, the stoicheion was originally a rhythmical-metrical term, which denoted the smallest element of a verse, and later became a grammatical term with the meaning of 'sound', 'letter'. The Atomists' use of stoucheion in the sense of 'constituent elements of the universe' was derived from the grammatical term (cf. Balázs, ib 234). 
stoicheion, since it shares with the Greek word the meaning 'component, small part, element'; the meaning 'letter' was original; the meaning 'particle' is the result of the development of the meaning of harf via 'small word' to 'small word other than noun or verb' and finally to 'third part of speech'. This development was already determined by the use of stoicheion in Greek grammatical and philosophical literature.

Besides the three official parts of speech, ism, fil, harf Arabic grammar recognized a number of other grammatical or syntactic categories without considering them to be real parts of speech. This is also the case in Greek grammar, where we find for instance the category of the adjective (epitheton), which is not regarded as a separate part of speech, although it is being used as such In a discussion between the grammarian Tryphon (lst century B.C.) and an unknown Stoic ${ }^{77}$ the criteria for the division into parts of speech are dealt with: the morphological change of a word (paraschèmatismós) can never be the criterion for a division into parts of speech. For instance in the case of proper names, even when they may be shown to possess a different declension, they are not a separate part of speech, since their meanıng is identical with that of the rest of the nouns: 'It must be said about each part of speech that we should take into account the essential characteristics (sc. the semantic ones), and not the secondary ones (sc. the morphological ones), and we should divide (the words) accordingly'. ${ }^{78}$ The same opınıon is expressed in Arabıc grammar: the proper name ('alam) has its own phonetic rules and its own deviations from analogy due to its frequent use, ${ }^{79}$ yet the

77 Scholia D T 214, 17 sqq , 24 sqq , 517, 33 sqq On Tryphon RE VII A, 1, 72644 Schneider, Apoll Dysk frg pp 30 sqq connects this discussion with Apollonios Dyskolos (cf also Schmidt, 1849, 44, n 64) His main argument is that it is improbable that Priscianus (instit 1, 2) should have borrowed his opinion about the partes orationis from Tryphon, and not from Apollonıos Dyskolos On the other hand. it seems more obvious to proceed from the fact that Tryphon's name is actually mentioned by the scholıasts Cr diso Prisc instit 9, I with Tryphon, frg 39, p 33

74 Scholid D T 214, 29-31 [Gill]

79 This is already recognized by Sibawaıhı, e g Kit 1, 229, 9 sqq, 2, 211, 11 sqq $\mathrm{Cr}$ also Ibn Ginni's chapter in the Hasä's on those characteristics of the proper names $\left(a^{\prime} / \bar{a} m\right)$ that are not shared by the generic nouns (ağnās), Has 3, 32, 8 sqq , cf Ta'lab, Mdḡ 1, 211, 8-9 The distunction ağnās / áläm Zağğ Lām 37-8, Zam Muf p 5 (imporlant for Bdrhebraeus' doctrine, of Merx. 1889, 235 sqq ) Laqab is used for proper names by al-Hasan ibn Suwär in his notes on the Categoriae, 371, 16 'A nuckname (lagah) is a name used for things which do alreddy have another name' [A 19] Laqah is dlso used in grammar, e g Zağğ Id 89, 16 noun ( $\mathrm{lsm}$ ), and attribute (ufa) and proper name (laqab) The difference between nouns and proper names is mentioned in some definitions of the noun, cf below, chapter III B 
proper name cannot be set apart as a separate part of speech. In the same way, Arabic grammar distinguished between 'general' ( $k$ ulli) and 'particular' (ğuz'i) nouns, but did not regard them as separate parts of speech: the distinction, which is probably borrowed from logic, is based on a difference in use and extension, not in essential meaning. ${ }^{80}$

We have already pointed out that adjectives were not recognized as a separate part of speech either in Arabic or in Greek grammar. ${ }^{81}$ The Greek grammarian Dionysios Thrax defined nouns as 'words which signify something concrete or abstract'. If it is accepted that this something may be a substance as well as a quality, then adjectives will be nouns as well, since they indicate a quality, which may be attributed to more than one substance. ${ }^{82}$ This is, of course, in accordance with the Stoic doctrine that everything, including the qualities, is a body. Adjectives are defined-as a subspecies of the nouns-in the following way: 'Adjectives are words that are used homonymously for general and proper nouns, and which signify praise or blame'. ${ }^{83}$ In Arabic grammar we find a de facto distinction between adjectives and substantives: in a discussion with Ibn Hālawaih, Abū 'Alī al-Fārisì is criticized for neglecting the distinction '... it was as if the learned sheikh (sc. al-Fārisī) did not distinguish between noun (ism) and adjective (sifa)! ${ }^{84}$ It is hardly a coincidence that several Arabic authors define adjectives as words that are used as indications of praise or blame. ${ }^{85}$ According to Diem, Sibawaihi distinguished

80 Thıs difference is explained by Rāzī, MaI 1, 40, 11 sqq , Gazz Mìyār, 36, 3-4, 6-7, 37, 11-6, Maq p 10 Cf Arnaldez, 1956, 127

i1 Steinthal, $1891^{2}, 2,251-60$

82 The category of the onomata kategoriká (1 e nouns serving as predicdtes) is conjectured by Steinthal $\left(189 !^{2}, 2,256\right)$, d class of adjectives called kategorika is mentioned in the scholia D T 233, 24 In the definition of the noun given by Ibn alAnbāri, Ins 2,14, the two syntactuc functions of the nouns are mentioned '(A noun is) that which can receive a predicate, and which can be used as a predicate', of below, chapter III B, note 3 ?

${ }^{33}$ Dion Thr 34, 2-4 [G 12]

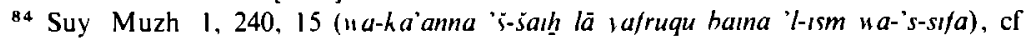
Suy Iqt 72,8 if a word is a noun, it has to be either solıd ( $\dot{g} \bar{a} m i d$ ) or an attribute (wasf) (on gäamid, of below chapter III C, note 73, and Ta'lab, Mağ 350, 8) The same distınction with Zağğ Id 89,16 noun ( $/ \mathrm{sm}$ ) or attrıbute ( $u / a$ ) or nickname (laqab) $\mathrm{Cr}$ also $b$ Kals ap b Anb lns 19, 7 'the nouns, but not the adjectives' (al-asmā' düna 's-sı/ät)

" 5 b Gın Has 2. 371, 2 sqq, b Fār Sāh p 56, of 61, 10. 'Abd al-Gabbār, Mugni, 7, 52, 15, Zam Muf 46, 12-5, Rumm ap Mubārdk, 1963, 315, 15, Ta'lab, Maǵ 2, 360, 12 
between three parts of speech, of which the ism indicates objects, the $\mathrm{fil}^{\mathrm{l}} \mathrm{l}$ actions, and the harf meanings (functions). The category sifa is a syntactic category which includes the adjectives but not only them: 'Das Adjektiv wurde seinem Wesen nach als syntaktisches Attribut aufgefaßt und stand damit außerhalb dieses Systems'. ${ }^{86}$ In later grammar ism became a grammatical category, so that abstract nouns and adjectives could be reckoned among the $a s m \vec{a}$. The criterium for the inclusion of a word in a category is whether it may replace words from that category. ${ }^{87}$

Morphological and semantic differences between the noun and the pronoun (e.g. different declension, absence of a deictic element in the nouns) led the Greek grammarians to separate the pronoun from the noun and to recognize it as a part of speech (antonumia) which included the personal and the demonstrative pronouns. ${ }^{88}$ The Aristotelikoi continued to regard the noun and the verb as the pivots of the sentence, and the rest of the words as unessential; in their view the pronoun was only a substitute for the noun. We may quote in this context the testimony of the above-mentioned discussion in the scholia, as well as the remark of Ammonios that Alexandros of Aphrodisias added the pronouns and the adverbs to the category of the nouns. ${ }^{89}$ Stoic grammarians did combine the personal and the demonstrative pronouns, but within the category of the arthra, which comprised besides these pronouns the article, as well as the relative pronouns. ${ }^{90}$ Their argument was that pronouns may be replaced by articles, for instance in Homeric Greek, and something which may replace a word is identical with that word, and belongs to the same category. ${ }^{91}$ This theory is criticized in the above-mentioned discussion between Tryphon and an unknown Stoic. ${ }^{92}$

It was precisely this argument of syntactic interchangeability that made Sibawaihi include personal and demonstrative pronouns in the category of nouns. ${ }^{93}$ The personal pronoun is called by him ism

${ }^{86}$ Diem, 1970, 331

87 This doctrine is refuted in the scholı D.T. 518, 33 sqq, and by Apollonios

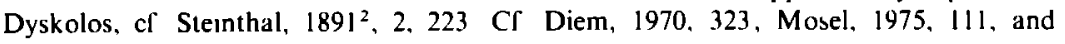
below, note 92 .

88 Steinthal, $1891^{2}, 2,213$ sqq

99 Scholia D T 515, $30 \mathrm{sqq}$. Alexandros ap. Ammon in Aristol de interpret 13 , 19-21, ed. Busse.

90 Barwıck, 1957, 35. Schmıdt, 1839, 39-42; Pohlenz, 1939, 164

91 Scholia D T 518, 33- 519, 5

$92 \mathrm{Cr}$. above, note 87

93 On thıs criterıum of Sibawaıhı: Diem, 1970, 323, Mosel, 1975, 111 
mudmar (hidden noun), but this term may also denote the noun to which the pronoun refers. ${ }^{94}$ Ism mudmar is apparently related to the Syriac term for the personal pronouns, huššabāaya (the understood one, the intended one); the origin of the Syriac term is not clear. A variant of the Arabic term, damir, became the usual name for the pronouns in Arabic grammar. The demonstrative pronoun is called by Sibawaihi ism mubham (dubious, ambiguous noun), because it may refer to many objects; ${ }^{95}$ a later term for the demonstrative pronouns is asmä' al-išära. Both categories, ism mudmar and ism mubham, are combined into one

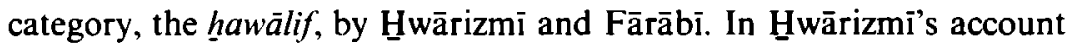
of Aristotelian logical theory he tells us that hawälif is a logical term, and that it is the equivalent of the grammatical technical terms asmä' mubhama, asmä' mudmara, and abdāl al-asmä ${ }^{3} .{ }^{96}$ Earlier in his work Hwārizmì deals with the theory of the grammarians, and there he asserts that in grammatical terminology asmä' mudmara denote the personal pronouns, and asmä' mubhama the demonstrative pronouns. The term hawalif was probably influenced by the Syriac term for the pronouns, which was originally ḥlā $\bar{p} \check{s} m \bar{a}$, before it became hušša-

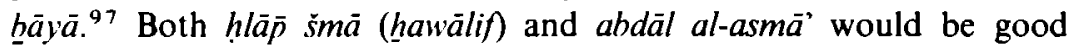
translations of the Greek term antônumiai.

Fārābì uses the term hawālif in his Kitāb al-alfāz al-musta'mala fi ' $/$-mantıq. ${ }^{98}$ In this work he describes the elements of speech in accordance with Greek grammatical doctrine-as he himself admits: Arabic grammarians did not distinguish between different kinds of hurūf, and he-Fārābī-had therefore had to borrow names for these different kinds of hurūf from Greek grammatical scholars, who operated with five categories: hawàlif, wāṣilät, wāsität, hawāši, rawāabit. ${ }^{99}$ The first category comprised the personal and demonstrative pronouns and has been dealt with above.

The second category, the wästlät, includes the article, the relative pronouns, and the particle of the vocative $y \bar{a}$. The combination of the

94 Mosel, 1975, 109, olher terms used by Sïbawathı are 'alämat al-mudmar, 'alämat al-ıdmär, damir

95 Sib Kit 1, 63, 16, 2, 42, 7, Diem, 1970, 317-8, Mosel, 1975, 122-5

96 Huār Maf 146, 2, ahdāl al-asmā' is also used by Ta'lab, Mağ pp 439-40. the grammatıcal passage $\mathbf{H} w \bar{d} r$ Maf 47, 3-4

97 Tarazi, 1969, 115, hläp śmā was already used in the Syrıac translatıon of Dionysıos Thrax' Téchnè

${ }^{98}$ Edited by M Mahdi, Beırut, 1968 This book has recently been the subject of two studıes, of Gàtje, 1971 and Haddad, 1969

${ }^{99}$ Far All 42, 11 sqq 
article and the relative pronouns is typical for Greek grammar, for instance in Dionysios Thrax' Téchné, where they together form the category of the arthra ${ }^{100}$ Even more characteristic is the combination of the article and the particle of the vocative the particle $\hat{o}$ was generally regarded as the vocative of the article, a doctrine refuted by Apollonios Dyskolos ${ }^{101}$ Arabic grammar often designates the relative pronouns as asmä' mausūla, and this grammatıcal term is related to Fārābỉs wäsılāt ${ }^{102} \mathrm{Wās}$ sla translates the Greek word árthron Mattā ibn Yūnus used it to translate arthron in his translation of Aristotle's Poetıca $^{103}$ In Ibn Sinna's commentary on the Poetıca, however, we find $n \bar{a}$ sıla as a synonym for ribāt, whereas the artıcles are called fásılāt ${ }^{104}$ Gatje solves this problem by supposing a division of the rawābut into two sub-groups, wāsılāt and fāslāt, the first sub-group being formed by the conjunctions proper, and the second by the articles ${ }^{105}$ In that case, the term fásula may be related to the Greek definition of the article, which was believed by some grammarians to serve as a sort of distinctive mark of the gender of the substantives, for instance by Diogenes of Babylon 'The artıcle is a declinable element of speech, which marks the difference in gender and number of the nouns, e $\mathrm{g} h o, h \dot{e}, t o ́$, hot, hal, tá' ${ }^{106}$ The Greek word dihorizon (whıch marks) has the same meaning as the Arabıc fäsıla It is not very surprising that Arabic grammarians regarded the article generally as a particle, since this word does not have any declension 107

The thırd group in Fārābi's divisıon is formed by the prepositions, which are called wäsität, because they always stand between two substantives, or between a verb and a substantive We do not know any equivalent in Greek grammatical terminology-the Stoıc term mesótès desıgnates the adverbs That Fārābì classıfies the prepositıons

\footnotetext{
100 Steinthal, $1891^{2} 2,309$

101 Apoll Dysk pron 6, 10, 14, 18 et passım, of Steınthal, 1891², 2, 309, Gatje, 1971,15

${ }^{102} \mathrm{Eg}$ b Anb Ins 380, 25, 303, 4, Lum p 51, Zam Muf pp 56-61, also sila Zam Muf 57, 3 Sibawaihı's theory of the relative clause Mosel, 1975, 155 sqq

103 Mattā ıbn Yūnus, ed Badawı, 1953, p 127

104 Ibn Sinā, Si'r, 191, 15, 191, 19, 235 pen

105 Gatje, 1971, 12

106 Diog Bab SVF 3, 214, 2-4 [G 13]

107 This group also includes according to Fārābī a category of logical quantifiers, such as $k u l l, b a^{\circ} d$, cf also Far Sarh, 63, 22 sqq, Hwār Maf 146, 3-4 (sūr), cf Zımmermann, Islamıc phılosophy, 1972, 5345 In Greek logıc such words were called sunkategoremata, cf Pinborg, 1967, 31 About the artıcle as a particle Gabučan, 1972, 35 (harf at-tärıf), Zağğ Lām 17-29
} 
as particles is quite understandable within the Greek context : in Greek grammar, the prepositions formed either a separate category or a subgroup of the conjunctions (sindesmoi prothetikoi). In Arabic grammar many words which we would call prepositions are included in the category of the nouns under the name zurüf. ${ }^{108}$

The adverbs, hawāši, constitute the fourth category of Fārābī's particles. If this word is really derived from the radicals $h-\breve{s}-w$, the meaning of this term is 'filling up, stuffing'. In that case haw'äs̆i means the same as the Greek word stoibai used by the grammarian Tryphon to indicate the group of the conjunctions. Calling these words stoibai implies that they are redundant, and that they only serve to fill out speech, as it were. ${ }^{109}$ Hasw in the sense of 'redundant word' is used by al-Kindi in the case of the word inna, which according to him has no real function in the sentence and is, therefore, unnecessary and redundant. ${ }^{110}$ Weil asserts that hašw is a Küfan term, but we know from Zamaȟšari that the term was used by Sỉbawaihi to indicate a special class of expressions which contain a redundant word. ${ }^{11}$ It is unclear how this root came to be used by Fârābi as a designation for the adverbs; most adverbs were called $\tilde{z}$ urüf in later grammar, and were classified as nouns after the example of Sibawaihi. ${ }^{112}$ For the classification of the adverbs as nouns there are parallels in Greek literature: Alexandros of Aphrodisias regarded the adverbs as nouns, and so did the Stoa in the case of adverbs derived from nouns. ${ }^{113}$

Fārābī's last category is formed by the conjunctions, rawähit. This term seems to be a calque of the Greek sindesmos; it persisted in

${ }^{10 \mathrm{H}}$ For the name of the $n a \bar{s} ı \bar{a} t$, cf perhaps Ibn al-Anbārī's remark that a partıcle can only have a meaning with the help of two words (b. Anb Lum 51, 7-8), and Zağğàğìs observation that the partıcle must be constructed with two words (Zağg. Id. $55,2 \mathrm{sqq}$ ) and that they join a verb with the genitive case with which it is constructed (Id 93, 10 sqq.).

${ }^{109}$ Tryphon, frg 41, p. 35; cf scholıa D T 66, 30, and maybe Varro, De L L 8, 10 (vulmentum)

110 Al-Kındi in a conversation with al-Mubarrad, reported by Rāzi, Mar. 2, 42 ult.$43,4$.

111 Weil, 1913, 72, n (instead of the Basrian Ilgā', cf Mahzzūmi, 1958, 315); Zam Mu「 57, 3 (in expressions such as alladi abühu muntalıq zard, where the normal term is sıla) Hasin was also used to indicate the middle of the word, as against the end or the beginning (taraf; awwal, mubtada'). b. Anb. Ins 11, 23; b Gin Has. 2, 329, 11 sqq , 2, 337, 13 Accordıng to Hwārızmi, Maf. 44, 7, hašw in this sense was already used by a)-Halil.

112 On the zarf: cf above, chapter I, note 40

113 Scholia D. T. S20, 16 and Schmidt, 1839, 45, n 66. 
Arabic grammar, as we have seen in the discussion concerning the meaning of harf. ${ }^{114}$

\section{B. THE NOUN}

Several definitions of the noun have been proposed by Arabic grammarians :

1. Mubarrad defines the noun, and at the same time describes it morphologically. His definition-which is mentioned by Zağğăğ and Ibn Fãris ${ }^{1}$-indicates the function of the noun as a sign of meaning: 'A noun is what denotes a meaning, such as rağul (man), faras (horse), and zaid, 'amr, and so on'. ${ }^{2}$ Nouns serve as 'names' for the objects, just as verbs serve as 'names' for the actions. In the discussions concerning the etymology of the word ism $^{3}$ Mubarrad expresses the same thought with different words, when he says 'A noun is what signifies a nominatum underlying it'. ${ }^{4}$

2. Morphological definitions of the noun-such as the ones transmitted from Mubarrad and from Hišām ibn Mu'āwiya-emphasize the fact that nouns may be in the genitive case; this is the one nominal case that is not shared by the verbs: 'A noun is a word which is able to receive one of the particles that govern the genitive, and, inversely, what cannot receive any of them, is not a noun'. ${ }^{5}$ How important this morphological feature is, is demonstrated by the fact that Zağğàği dedicates one very lengthy chapter to the question why verbs do not have a genitive. ${ }^{6}$

3. Some definitions distinguish between 'general' and 'individual' nouns. Stoic logic correlated the difference between individual terms

114 Cf above

1 Mub. ap Zağğ Id 51, 2-3 [A 20] (quotatıon from the begınnıng of the Muqtadab), b. Fār. Sāḥ 50, 19-20.

${ }^{2}$ On these paradigmata above, chapter III A

${ }^{3}$ Cf below, chapter IX.

4 Mub ap. b. Anb lns. 2, 10 (al-ısm mā dalla "alā musamman tahıahu). Cf also the definition given by 'Ukbarī, Mas. 43, 6: 'A noun is what names its nominalum and explains $\mathrm{tt}$ and reveals its meaning' [A 21]. Cf Diem, 1970, 316.

5 Mub. ap. Zağğ. Iḍ 51, 3-4; cf Hiš ap. b. Fār. Sảh. 50, 9 [A 22]; umtunia mın dálıka. the same terminology in the definition of the verb, of below, chapter III $\mathrm{C}$, note 1 .

6 Zağg. Id. pp 107-20. 
and generic ones-which is a difference in logical connotation-with a grammatical distinction between proper nouns (onómata) and common nouns (prosègoriai), ${ }^{7}$-two parts of speech where older grammar had had only one. Thus we find in the Perì phônes of the Stoic grammarian Diogenes of Babylon two definitions: 'A common noun is a part of speech which signifies a common quality, such as anthropos (man), hippos (horse). A name (proper noun) is a part of speech which signifies an individual quality, such as diogénès, sôkrátès'. ${ }^{8}$ Pohlenz tried to explain this distinction of two sorts of nouns in terms of the Stoic doctrine according to which only the individual phenomena possess a real existence, whereas the lektá (translated by him as 'general notions') are only found in speech. ${ }^{9}$ This explanation is rather unsatisfactory: the word diogénès is as much a lektón as is the word anthrôpos $i^{10}$ only their denotata (tunchánonta) differ inasmuch as they are either individual qualities, or qualities shared by several individuals. As a matter of fact, the grammatical distinction is already to be found in Aristotle's writings, who interprets the division of the nouns into two categories in terms of the distinction between genus and species: ${ }^{11}$ "As some things are general, other things individual-I call "general" something which can be naturally predicated about several objects, and "individual" something which cannot be predicated in this way, e.g. anthropos is general, and kallias is individual-, it is necessary to show in which way something is present or absent in a substrate'. ${ }^{12}$ The Aristotelian distinction is found in Arabic grammatical writings,

7 Christensen $(1062,49)$ explains the distinction as follows: 'The meaning of a proper name is an "Individual qualıty" (ıdia poiótès) By assertıng an individual quality of a region of reality, we refer to that region as being the region of exceedingly complex motion of high stability and permanence, since Socrates is what in physics might be called a high-level tensional field .. The meaning of "Socrates" is intended to imply the unique set of true propositions that can be made about Socrates' The common nouns, on the other hand, denote 'field' with common qualıties (koinè poiótès). On the grammatıcal distinction. Schmidt, 1839, 43-4; Barwick, 1957, 35.

Diog. Laert. 7, 58 = SVF 3, 213, 27-31 [G 14]; of Steinthal, 1891², 2, 237 sqq.

9 Pohlenz, 1939, 163.

${ }^{10} \mathrm{Cr}$. however Long, $1971,77-8 ; 104-6 \cdot$ the meaning of a word such as dion is not a lekton, but the object signified by that word, viz. Dion himself.

"Koinos vs. idios: Aristot categ. 2 b 8-13: "If you wish to show what the first substance is, you will make it more recognizable and more particular by mentioning the species than by mentioning the genus; for instance, you will make a certain person more recognizable by calling hım "man" than by calling him "living being"-the first attribute is more characteristic for that certain person, the second more general' [G15].

12 Aristol. de interpret. 17 a $38-17$ b 2 [G 16]. 
for instance in Gazzāli. ${ }^{13}$ The difference between the Aristotelian and Stoic distinctions is that Aristotle defines the logical extension of general and individual nouns, whereas the Stoics are more concerned with the nature of the objects denoted by those nouns: some philosophers like Philoponos and Romanos even modified the definition by substituting the word 'substance' (ousia) for 'quality' (poiótès). ${ }^{14}$

The Stoic distinction disappeared from Greek grammatical literature, but it left some traces. Dionysios Thrax explicitly mentions the distinction between proper and common nouns, although he disagrees with it: 'The common noun is a subspecies of the noun'. ${ }^{15} \mathrm{His}$ definition of the noun is also interesting in this respect: "A noun is a declinable part of speech ... which may be used generally or individually, generally like anthrôpos, hippos, individually like sôkrátès'. ${ }^{16}$ It will be noted that Dionysios uses the same paradigmata as Diogenes did. The arguments adduced by the scholiasts in defending the distinction between proper and common nouns are purely grammatical, and probably not derived from Stoic sources. ${ }^{17}$ They need not bother us here, but are more relevant in the discussion about the Arabic division of the parts of speech as compared with the Greek division. ${ }^{18}$ Still, the discussion proves that the Stoic distinction was not lost totally, which is also apparent in the definition of the noun, attributed by Priscianus to Apollonios Dyskolos: 'A noun is a part of speech which shows the individual or general quality of the underlying concrete or abstract things'. ${ }^{19}$ The influence of the Stoic distinction is also manifest in Latin grammar. ${ }^{20}$

In his Ihṣă al-ulūm Fārābì describes the single words as follows: 'Some single words are names of persons, such as zaid, amr; other

${ }^{13} G u=` i$ vs kulli Gazz Mìyār, 37, 11-6, cf 36, 3-4, 6-7, Maq p 10 Cr Amaldez, 1956. 127

14 Choirob 1, 106, 5-7 (cl Steınthal 189/2, 2, 239) 'A noun is a declinable part of speech, which assigns to each of the underlyıng concrete or abstract things its general or individual substance' [G 17] Probably this Philoponos is Johannes Philoponos an-Nahui, the philosopher-grammarian, cf below, chapter VI, note 40

19 Dion Thr 23, 2-3 (hè gar proségorıa hòs eidos tô onómatı hupobéblèral)

16 Ib 24, 3-6 [G 18]

${ }^{17}$ Scholia D T 214, 17 sqq, cf above, chapter III A, note 78

${ }^{18} \mathrm{Cf}$ above, chapter III $\mathrm{A}$

${ }^{19}$ Prisc de XII vers Aen 6, 95 Nomen est pars oratıonis quae singularum corporalium rerum vel mo orporporalium sibi subiectarum qualitatem propriam vel communem manifesiat On this definition Schneider's remarks, frg Apoll Dysk, pp 38-9, Steinthal. $1891^{2}, 2.240$

20 Barwick, 1922, 106 
(single) words denote the species and the genus of the objects, such as insān (man), faras (horse), hayawān (animal), bayā (whiteness), sawād (blackness)'. ${ }^{21}$ Fārābīs pupil and teacher, Ibn as-Sarrāğ, introduced the distinction into grammar with his definition of the noun, the one quoted by Zağğāği: 'A noun is what signifies a meaning, and this meaning is an individual thing, or a non-individual thing' ${ }^{22}$ Connected with this definition is the one quoted from Ibn Kaisān: 'A noun is what indicates individuals, and what has a meaning of its own, such as ragul (man) and faras (horse)'. ${ }^{23}$ In this form, however, the definition can hardly be correct, since it only mentions the proper nouns (individuals), but with the examples for the common nouns. This does not make sense: we can hardly consider the words 'man', 'horse' representative for individuals (ašhăș). Somehow, the missing parts of the definition must be supplemented, namely the examples for the individual things, and the name of the group of words represented by the two examples given.

4. Nouns may be defined syntactically in that they may serve as the subject of a sentence, unlike the verbs or the particles, for instance in a definition ascribed to al-Aḩaš Sa $\mathrm{i}$ id ibn Mas'ada: 'A noun is that about which it is permitted (to say) "it helped me", "it harmed me"' ${ }^{24}$ There is a second version of this definition, quoted by Ibn Fāris, ${ }^{25}$ which seems to be the original one. ${ }^{26}$ The general meaning of the definition is very close to that of the definition reported by Ibn Fāris from Sibawaihi : "A noun is that about which something is told'. ${ }^{27}$

21 Far. Ihs 11, 14-12, 2 [A 23]; of Alf 58, 12-59, 4. an almost literal translation of the Aristotelian text quoted above, note 12; here the examples are 'man', and 'zard', "amr" the Aristotelian context leaves out "horse"' On universals vs particulars in Islamıc logic. Zımmermann, Islamıc philosophy, 1972, 518, 527, and note 11 with quotatıons from Fãrābï’s Sarh al-'ibära

22 Zağğ Id 50, 5-6 [A 24], cf. also b Anb. Asr. 5, 19-20.

21 Zağğ Id $50,12-3$ [A 25].

24 Zağğ Id 49, 12, the addıtıon 'to say' is form Zağgāăgi hımself [A 26]

2 's Fār Sāh 50, 7-8

26 Instead of gäza fihı (it is permitted) the expression hasuna fihı is used here, which is also used in another definition of the noun by al-Aḥfaš, ap. b Fār Sāḥ. 50, 5-7 The same expression in two anonymous definitions of the verb, which are transmitted by Ibn Fārıs, Sāh 52, 11-2, 13-4 (cf Tarazi. 1969, 144), and in Zağğāğīs definıtıon of the verb, Gum. 21, 13, 22, 2 'To help' (nafaia) and 'to harm' (darra) are possıbly borrowed from a Qur'anic verse, Qur`ān, 22/12-3, this verse is discussed by al-Ahfaš ap Ta’lab. Mağ 592, 2-3 Sĩrâli uses in a sımilar context the verb a'ğaba (to wonder), in marg Sib Kit 1, 123, 7

${ }^{27}$ b Fār Sāh. 49, 7-8 (al-ısm huu a \%-muhaddat "anhu) 
Another definition of the noun from al-Aḩfaš, also mentioned by Ibn Fāris, may be quoted as well, since it not only includes the verbal, but also the adjectival predicates: 'When you find a word with which the verb and the adjective may be properly used, such as "Zaid stands", or "Zaid is standing", and when you find moreover that it has a dual and a plural, such as zaidānı, zaıdūna, and when you find that it cannot be conjugated, know then that it is a noun'. ${ }^{28}$ These three definitions have in common that they are formulated in syntactic terms: a noun is characterized by the fact that it may be subject of a sentence. There is apparently a connection with the Mutazilite definition of 'thing' (say'): 'A thing is something about which something may be predicated'. ${ }^{29}$ We know that al-Ahnfaš was indeed a Mu'tazilite. ${ }^{50}$

Al-Ah̆faš definition met with critical remarks from other grammarians. Zağğāğ $\overline{1}$, for instance, does not accept it, since it does not include words such as aina (where?), kaifa (how?). About these words nothıng can be predicated, but they are nevertheless reckoned among the nouns. ${ }^{31}$ This criticism is also mentioned by Rāzī, ${ }^{32}$ who defines the noun as 'something about the meaning of which something can be predicated'. ${ }^{33} \mathrm{He}$ remarks: 'Some people object to the words "noun is that about which you can predicate something", since, as they say, "where", "when", "how" are nouns, but you cannot predicate something about them. 'Abd al-Qāhir, the Grammarian, gave the following answer to this: When we say "noun is that about which you can predicate something", what we intend to say is: "(noun is) that about the meaning of which you can predicate something". As a matter of fact, it is possible to predicate something about the meaning of $i \underline{d} \bar{a}$ (when), since when we say àtika id̄a tala at aś-šams (I will come to you when the sun rises), the meanıng is àtika waqt tulü aś-šams (I will come to you at the time of the rising of the sun). About the word waqt (time) you can predicate something, as is proved by the

2A b Fār Sāh 50, 5-7 [A 27]

29 This definition of say stems from the Stoic tradition, of Rescher, 1966, 69-70, and below, chapter VII, note 33

${ }^{30} \mathrm{Cr}$ chapter VIII, note 10

${ }^{31}$ Zağğ Id 49, 14 50, 4, 'Ukb Mas 54-7

32 Rãzī, Mal 1, 33-4

33 Ib $1,34,13$, the complete form of the definition 1b 1, 32, pen 'The word which allows predication about itself and with itself is a noun', as agansi the verb, which allows only predication with itself, not about itself, and the particle, which dllows nether $\mathrm{Cf}$ the Basrian doctrine, reported by lbn d-Anbārī, Ins 2, 13 sqq 
expression täba ' $l$-waqt (the time is good)'. ${ }^{34}$ This discussion is continued in 'Ukbarī's Masā'il hilä́liyya; after reproducing 'Abd al-Qāhir's argument, 'Ukbarī tries to refute it. His conclusion is that adverbs are nouns, but that it is nevertheless impossible to predicate something about them. ${ }^{35}$ This conclusion makes al-Ahfaš' definition unacceptable to him.

5. According to Zağğāğī the only correct definition of the noun, if one is to work along grammatical standards, is his own definition: 'A noun in the language of the Arabs is something active $\left(f^{-}{ }^{a} i l\right)$ or passive $(m a f \bar{u} l)$, or what takes the place of something active or passive.' ${ }^{36}$ There are other definitions, he says, but those are correct only from a logical point of view. At first sight, he seems to define nouns in terms of 'subjectivity' and 'objectivity'; in that case his definition would be a syntactic definition, just as the definition of al-Aḩfaš mentioned above. But Zağğăğì quotes al-Ah̆faš’ definition as an example of a definition in terms of 'subjectivity' (taqrib 'ala $\%$ mubtada'), ${ }^{37}$ and he criticizes it for precisely this reason: adverbial nouns can never be the subject of a sentence; still, they are nouns. This suggests that we should interpret Zağğăğì's definition differently, and that the terms $f \bar{a}^{\mathrm{e}} i l$ and $m a f \bar{u} l$ do not denote activity and passivity in a grammatical sense, but in a physical sense. ${ }^{38}$

34 Rāzī, Maf 1, 33 [A 28]. Cf Rāzì's answer, Maf. 1, 34, 2-7. The 'Abd al-Qāhır the Grammarıan who ligures here and in 'Ukbarī's account is 'Abd al-Qāhır ıbn 'Abd ar-Rahmān al-Gurğāni an-Nahwī, the author of Dalä'll al-ī ḡāz and Asrār al-haläga (d 1078/471), cf Brockelmann, GAL I, 341; S 1, 583, Suy. Buġya, 2, 106, nr $1557 \mathrm{He}$ also wrote a Mugini fi šarh al-Iḍahh, but that may be Fārısìs Iḍăh.

35 Ukb. Mas. 53, he uses the same arguments as Zağğāği does, Id. 51, 14- 52, 8, in his answer to those who crilıcize Mubarrad for this definition (an argument in terms of general principle and exception to the rule)

36 Zağg Iḍ. 48, 6-7 [A 29]

${ }^{37}$ Zağg. Id 49, I3, cீ above

${ }^{38}$ This notwithstanding the fact that the same terms are used elsewhere in a grammatical sense: Ibn al-Anbāri tells us that one of the characterıstucs of the noun is that It may be active or passive, e.g in the sentence daraba zaıdun amran (Zaid hit 'Amr); what he means is that a noun may be subject or object of a sentence (Asr 6, 6-7; cr. also Rāzi, Maf. 1, 34, 17). Fä'll and maf ül do not correspond exactly to our 'subject' and 'object" in the sentence duriha zard (Zaid was hit) zand is the maf'ül in Sibawaihi's termınology, cf Mosel, 1974, 246-7. Zag̉ḡāğì hımself uses $f \bar{a}^{*} l l$ and maf'ül in another definition of the noun in thesr grammatical sense, Gum 17, 6-7. A noun is that which may be used as a subject $\left(f_{\bar{a}}^{\prime} l\right)$ or as an object (maf $\left.\bar{u} l\right)$ ' [A 30] The difference with the definition in the $\bar{l} d \bar{a} h$ is emphasized by the words " which may be used .... in the Gumal Zağgagaği deals with the possibılıtıes of the syntactıc use of the noun, not with the nature of the substances denoted by $\mathrm{tt}$, which are always active or passive 
In order to clarify this we would like to call in evidence a few Greek texts. Dionysios Thrax: 'A noun has two dispositions, action and passion, e.g. kritès (a person who judges), kritós (a person who is judged)'. ${ }^{39}$ Scholia on Dionysios Thrax: 'It is always the substance which is doing something or undergoing something, whereas the verb signifies the action or the passion'. ${ }^{40}$ Apollonios Dyskolos: 'The noun precedes the verb of necessity, since to act or to be acted upon is characteristic of the body, and the giving of names concerns the bodies. From the names is derived the characteristic property of the verb, namely the action and the passion' ${ }^{41}$ Being active or passive, according to these definitions, is something characteristic for substances, which are represented in speech by the nouns. Verbs represent the actions of the substances.

This suggests that Zağğăğìs definition must be explained in the following way: there is a well-known dictum about nouns signifying substances, and verbs actions; we know that substances are the agents of the actions which are indicated by the verbs (or, indeed, the objects of such an action by another substance); we may conclude, then, that nouns are characterized by the fact that they are active or passive. This definition is connected with the discussions about the priority of nouns, ${ }^{42}$ and we may deduce from its existence that the doctrine according to which nouns signify substances, and verbs actions-which is why nouns are prior to verbs - was known in the Arabic world, even though the specific formula is not found in these discussions. What we have here is probably a Stoic doctrine. The Stoa asserted that every substance is a body, and that activity and passivity are among the essential attributes of the bodies. ${ }^{43}$ This Stoic dogma is found in the

39 Dion Thr. 46, 1-2 [G 19]

40 Scholia D.T 515, 16-8 [G 20]; cf. 215, 28-30.

41 Apoll Dysk synt. 18, 5-8 [G 21]; of Steinthal's translation, 1891'2, 2, 233: 'Das ónoma aber geht dem rhèma voraus, weıl das Bewırken und Bewirktwerden dem Körper angehórt, und auf die Körper sich die Gebung der Namen erstreckt, aus denen sıch die Eigentümlıchkeıt des Verbums, namlıch das Tun und Leiden, erst ergibt'.

42 Cr below, chapter VII, n. 88.

43 Cf. SVF 2, 359: body (sôma) and substance (ousia) are identical, ib 2, 363: somethıng without a body (to asomaton) is unable to act or to suffer; on the 'dynamic concept' of the Stoic bodies: Sambursky, 1971², 95-6. The doctrine that only bodies possess existence was introduced into the Arabic world under the influence of the Stoa, cf. Jadaane, 1968, 137-47; for the connection between Nazzāam's theories and Stoic materialism. Horowitz, 1903 (Nazzām held that atoms can be divided infinitely, and that a body is nothing more than an assembly of accidents, which are corporeal, cf. Nader, 1956, 155-8); on Mu'tazilıte materialism in general: Nader, 1956, 150-67. 
Arabic translation of the Placita phlosophorum: 'Everything which acts or is being acted upon is a body'. ${ }^{44}$ But, of course, an explanation of the difference between nouns and verbs in terms of action and passion is quite common: we find it as early as Plato. ${ }^{45}$ Our conclusion that this definition of nouns really deals with substances rather than with nouns themselves, is confirmed by the fact that apparently the objection to al-Ahfaš' definition is not applicable: substances denoted by words such as kaifa, aina are actually regarded as something active or passive, which makes them fall under this definition. $^{46}$

In the Greek world there was no definition of the nouns similar to the one proposed by Zağğāği, since Greek grammarians did not combine data from the discussions about the hierarchy of the parts of speech with the definitions of these parts of speech. It is evident that we are here concerned with a definition which is completely different from the Aristotelian tradition: not only from a terminological point of view, but also with regard to the substance of the definition: Aristotle is interested in the linguistic properties of the definiendum, c.q. the noun (nouns do not have tenses, nouns are conventional signs, no part of a noun is meaningful in itself). This definition, however, tries to define the nature and the physical properties of the objects denoted by the definiendum, c.q. substances (substances always play an active or a passive role in the actions denoted by the verbs).

In his Rhetorica Aristotle uses the term hellenizein in the sense of 'speaking uncorrupted Greek without using wrong words or making grammatical mistakes'. ${ }^{47}$ It is on this use of the word that Merx bases his identification of the word $i^{2} r a \bar{b}$ (declension) with hellenismós, but he does not explain the difference in meaning: although the identification of the two words as to form may be correct-both words are causatives with the same lexical derivation--, the difference in technical meaning cannot be explained away. The term hellenizein as it is used by Aristotle - who does not use the substantive hellenismós-has a much wider range than the Arabic term, which only means 'declension of nouns and of those verbs that resemble nouns'. The solution

44 Plac. Phil. 277, 18 [A 31].

45 Plato, Soph. $262 \mathrm{~A}$ : "the sign for the actions is what we use to call rhema and the phonetic sign for those who perform those actions onoma' [G22]; of also the discussion about the priority of the nouns, below, chapter VII.

${ }^{46} \mathrm{Cf}$ above, note 31

47 Arstot rhet III, 1407 a 20 
may be that Merx wrongly based his argumentation on the Aristotelian use of the word exclusively, and that he disregarded later developments in Greek grammar. In order to clarify this we must turn to Sextus Empiricus, who tells us a good deal about later grammar-he lived about 150 A.D.-notwithstanding his critical attitude towards grammar as well as all other dogmatic disciplines. Sextus says: 'They (sc. the grammarians) compose general theorems, and from these they pretend to be able to judge about every single word, whether it is Greek or not'. ${ }^{48}$ These general theorems ${ }^{49}$-also called kanónesformed the core of the so-called Téchnai peri hellenismồ; they were meant at first as a description of the actual state of the language, but soon became normative rules for teaching purposes. As the téchnai were primarily concerned with the declension, ${ }^{50}$ the word hellenismós itself came to be used in the sense of 'declension': one may compare with this the Stoic definition of the word hellènismós: 'Correctly inflected speech in the civilized, and not in the vulgar way of speaking'. ${ }^{51}$ Considering the fact that the word kanónes has been arabicized by the Arabic grammarians (qänün, plural: qawänin), we believe that these treatises about flexion somehow served as a model for the first attempts of the Arabic grammarians to describe their own language. The imitation of the kanones which is found in the fragments of Jacob of Edessa may have played an intermediary role in this respect. $^{52}$

We have a description of such a treatise which determines the flexion of nouns and verbs by means of qawänin, in the section about grammar in al-Fārābī's $I h s ̣ a \bar{a}$ ' al-'ulüm: ${ }^{53}$ 'Then, it (sc. the qānūn)

48 Sext. Emp adv. math. 1, 221 [G 23]

49 For this meaning of katholkkós and the difference between hóros and katholikón: Sext. Emp. adv math 9, 8 = SVF 2, 224 In Latın grammar we have Varro's universa discrimina, De L.L 10, 8 sqq. and Char. 63, 16 sqq.

so Barwick, 1922, 182: 'Es muß also einen Typus grammatıscher Lehrschrift (téchnè peri hellènismoû) gegeben haben, der die Darstellung der Flexıon zum Gegenstand hatte mit der ausgesprochenen Absicht Regeln rür den rıchtıgen Sprachgebrauch (hellènismós, latinutas) an die Hand zu geben'.

${ }^{31}$ Diog. Laert. 7, 59 [G 24] For the word adıáptôtos in this definition, of Liddell/ Scott, s.v., especially the quotation from Apoll. Dysk. pron 109, 23, where the word is translated as 'not using the cases at random'; cf. Steinthal, 1891 2 , 2, 121; 126.

52 Merx, 1889, 56-62. Jacob of Edessa followed the example of Dionysios Thrax and Theodosios. We will not enter here into the question of the relationship between these Syrıac kanónes and al-Fārābi’s description of the kanónes

53 The rest of Fārābī's section about grammar also shows a remarkable influence of Greek terminology, cf. lawähıq, p. 14 (= parhepómena); wuğūh, 14, 14 (= prósôpa; cf Daiber, 1968, 25. The Syriac term parsūpā, Merx, 1889, 17; 19; Tarazi, 1969, 115, is a transliteration of the Greek word); tașarruf (=klists), cf below, chapter III C. 
teaches us in which case which ending is attached to each noun and each verb, then, it enumerates briefly the cases of the singular nouns, case by case, for those nouns that are declinable and can receive in each case one of the endings, then, it does the same for the feminine, the dual, and the plural nouns, then, it gives the same list for the singular, the dual, and the plural verbs, untıl all cases which change the endings of the verbs have been exhausted, then, it informs us which nouns are only declined in some cases, and in which cases they are declined, and in which they are not, then, it informs us which nouns have only one case-ending, and which ending each of these (nouns) has' 54 This description corresponds exactly to the Greek kanones onomatikol and kanones rhematikol, as we know them from Theodosios, even in the distinction of words which are declined only in one case, or only in some cases ${ }^{55}$ The order of the Fārābıan flexional tables is the same as the one we know from Greek examples This proves that there still existed at this time traces of the Greek flexional tables with general rules about the flexion of nouns and verbs The general character of these rules is correctly defined by Ibn Haldūn 'They (sc the scholars) extracted from the course of their own speech general rules, and by means of these rules they judged about the rest of the forms of speech, and they attached similar endings to similar words' 56 Viewed in this light the difference between the Aristotelian hellenismós and the Arabic iräb is no longer a problem iräb in fact translates the hellenismós of later Greek grammarians

Our explanation does not take into account the explanation of the Arabıc grammarians themselves They translate iräb as 'explanation' (bayän) ${ }^{57}$ In their view the $i r a \bar{b}$ is the focal point of grammar, which gives the Arabic language its clarity - even to the point where some of them believe that the Arabic language is the only language to possess an irāab ${ }^{58} \Gamma r \bar{a} b$ in the sense of 'declensıon' is defined as follows declension is a vowel at the end of the word that indicates the meanıngs (sc the grammatical meanıngs ${ }^{59}$ ) It should be added that

s4 Far Ihs 16, 11- 17, 9 [A 32]

55 Grammatict Graect, IV, 1, ef Gluck, 1967, 23 and n 6, the distınction between monoptôta and aptôta Barwıck, 1922, 177 sqq , Steınthal, 1891 22 2, 224-6

56 b Hald Muq 546, 18-20 [A 33]

${ }^{57}$ Zağg Id 91, 3-8, b Ğın Has 1, 36, 2- 37, 4, b Anb Asr 9, 16 sqq, cf Fuck, $1955^{2}, 25,60$

sa E g b Fār Sāh 42, 161

s9 Zağğ Iḍ 72, 2-3 For haraka = kınesıs of above, chapter II, The 'meanıngs' 
declension is a semantic, not a phonetic matter, or, to put it in Rãzì's words, 'the declension is a rational, not a physical state'. ${ }^{60}$ This was recognized already by the scholiast on Dionysios Thrax, who says: '(it should be known) that the five cases are a matter of meaning, not of sound'. 61

Words with a complete declension (triptotic words) are called in Arabic grammar from the time of Sibawaihi munsarif, words with an incomplete declension (diptotic words) are gair munsarif. ${ }^{62}$ As the nunation indicates the complete declension, ${ }^{63}$ in some cases sarf and tanwin are very close to each other in meaning. ${ }^{64}$ We believe that the term sarf is connected with the Greek word klisis, although the exact relation between the two terms is very difficult to trace.

Two things are more or less certain. In primitive Arabic grammar the term used for 'declension' was i'räb, in our view a calque of the Greek hellènismós. On the other hand, in philosophical circles the terms șarf and tașrif are consistently used for all morphological changes of nouns and verbs, but this term is, of course, found only after the first translations of Greek writings had been made. We find, for instance, in Mattā ibn Yūnus' translation of Aristotle's Poetica the term tașrif as the translation of the Aristotelian ptosis, i.e., the inflection of both nouns and verbs. ${ }^{65}$ Ibn Suwār tells us: "Inflection ( assing is a sound added to the word and consisting in a vowel that is added to the first case (istiqäma) ... and there are five kinds of inflection (i.e., five cases), as I have mentioned in the De Interpretatione'. ${ }^{66}$ The same is said by al-Fārābì who distinguishes between nouns in the first case (mustaqim) and inflected nouns (mäil); both nouns and verbs have inflection (tașiff) ${ }^{67} \mathrm{It}$ is obvious that we are

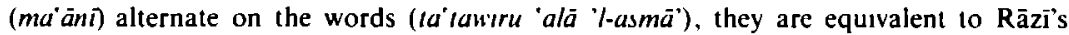
'states that occur to the nouns' (ahwäl 'ärıda 'alä \%asmā'), Maf I, 45, 7 sqq Zağğ. Iḍ. 69, 6 sqq. gives examples of these meanıngs.

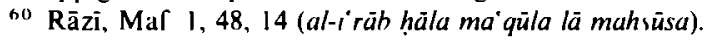

${ }^{6}$ Scholı D T 230, 34-5 (tôn sèmaınoménôn ou tôn phônôn cisın hat pénte ptôsets), cf Schmidt, 1839, 59

62 Wright. 1964', 1, 234-47 (the trıptotic and the diptotic declension); Sıb Kit.

1, 7, 6, cf also the detalled analysis, ib 2, 2-13

${ }^{63}$ Cf. Zağg. Id 97, 3 sqq

${ }^{64}$ E g Zağg̀ Mağ 92, 7 sqq

ns Mattā ibn Yūnus, Badawī, 1953, 128, 20-4, cf Ibn Sīnā, Șír, 191, pen., b. Rušd, Sı'r. 236, 14-8

66 b Suwār, 372, 47 [A 34]

${ }^{67}$ Far Sarh. 32, 15;36, 8; 42, 21, Ihs p 16 Cf Islamic phlosophy, 1972, pp 521 sqq 
dealing here with a direct translation of Greek words, where $m \bar{a}^{\prime} i l$ stands for enklinómenos, mustaqim for orthós, and the term tasrif itself for the word used by the Greek commentators of the writings of Aristotle and the Alexandrian grammarians alike, namely klisis. ${ }^{68}$ The tassif is an imitation of the Greek declension, c.q. inflection, as is evident from the five cases given by Ibn Suwār.

In Alexandrian grammar klisis was used for the morphological changes of nouns and verbs, whereas other (analogical) changes of words were indicated by the term paragoge $e^{69}$ In the Stoic-Pergamene type of grammar, klisis was used for every change of a word, be it regular or irregular. ${ }^{70}$ Later distinctions allowed to nouns a ptosis and a klisis, but to verbs only a klisis: ${ }^{71}$ verbs are áptôta, just as, for instance, adverbs and prepositions. ${ }^{72}$ Among the nouns there are also those with only one case (monóptôta), e.g. the name ho abraám; nouns are called áklita, when they miss some of their cases. ${ }^{73}$

According to the Arabic grammarians, only nouns are declinable (mu rab), whereas verbs have no right to declension, although they do have an inflection (tasrin). ${ }^{74}$ On the other hand, nouns are divided into those which are fully declined (munsarif), and those with only two cases: the latter category is called gair munsarif, and it seems that we have here the equivalent of the Greek term áklitos, which we have mentioned in the preceding paragraph. The Arabic theory, according to which nouns lose something of their declension on

6* Islamic philosophy, 1972, 521 sqq

69 Barwick, 1957, 34

70 This was precisely the reason why the debates about analogy and anomaly were so fruitless both parties disagreed as to where andlogy was to be demonstrated, ef Barwıck, 1922, 179 sqq

${ }^{71} \mathrm{Cf}$ scholia D T 549, 33, on the question why the terms klisis and ptosis are used for the nouns, but only the term kliss for the verbs Unfortunately the answer has not been preserved in the manuscript It is difficult to find out what exactly a kliss of the nouns is From the way Apollonios Dyskolos uses the term it appears that klisis denotes every morphological change of etther a noun or a verb, and that ptôsts is the special name for a $h / i s / s$ of a noun

72 Steinthal, $1891^{2}, 2,224-6$

${ }^{73}$ Scholla D T 231, 12-5 'How does the monoptoton differ from the akliton? (Answer) the monoptoton receives only the artıcle, e g ahraam, but the ákliton is a word which nether receives (only the article), nor docs it have a complete declension. e g oûs (ear), démas (stature)' [G25] Also Apoll Dysk synt 47, 8 adjectıves lıke tachu (swift), which are used as adverbs, become $a h l i t a$, thus imilating the undeclinability of the adverbs this is the only trdce in Greek grammar of a theory of resemblance (cf below) $\mathrm{Cr}$ also Chorrob 1, 341, 24-37 (on the names of the letters)

${ }^{74}$ Zağğ ld $80,7-9,101,5-6$ (a quotation from Td'lab) 
account of a resemblance to the verbs or the particles, was, however, unknown in Greek grammar.

Șarf and tașrif have yet another meaning in Arabic grammar. The science of sarf is defined as the science of the phonetic forms of words and their changes, apart from those changes that are caused by declension. We may cite the following definitions: 'It (sc. the sarf) is the science of the roots, by which we know the various phonetic forms of the words, apart from the declension' (Ibn Hāğib); ${ }^{75}$ 'It is the knowledge of the root of the word, and its additions, elisions, and changes' (Ibn al-Atîr). ${ }^{76}$ Apparently șarf could indicate every change of the word in general, i.e., almost the same meaning as the Pergamene use of the word klisis. Perhaps this may be explained by the fact that in Arabic as well as in Greek grammar ptôsis/i räb was reserved for the nouns, so that its opposite klisis/sarf could obtain the double meaning of 'inflection of the verb' and 'derivation in general'. Whatever the case may be, it seems rather probable that sarf is the translation of the Greek term klisis, since both words indicate a departure from the original meaning or form of the word-the original meaning of klisis is 'bending, inclination', normally in a downward direction, but also aside, whereas sarf means 'tuming away, averting'. In philosophical grammar this change in meaning by means of a phonetic change applies to the declension of the nouns and the verbs; in grammatical works it refers either to the inflection, or to every change apart from those caused by declension. When the word is used in this second sense, it has a sub-category, "adl, which indicates more specifically the analogical derivation of one form from another: Ibn Ginni says that "adl is a kind of derivation (tasarruf), which consists

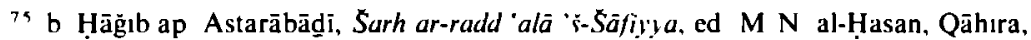
$1358 \mathrm{~A} \mathrm{H}, 1,2,3$ [A 35]

${ }^{76} \mathrm{~b}$ al-Atīr, al-Maı́al as-sā’ir, ed. M.N 'Abd al-Hamìd. Qāhıra, 1358 A.H , 1, 12 [A 36]. Both this definition and the one quoted in the preceding note are quoted by 'Ubaidi. 1969, 98-9, who discusses several other definitions, as well as the place of sarf within grammar Compare Flugel's note 1862, 13-4, note 2 On the etymology of sarf: 'Ukb. Mas 106-9 We are not concerned here with another use of sart, namely in Küfan grammar, where this term is used for the procedure that causes the accusative in sentences such as lä ta'kul as-samah wa-tasraha \%-lahan (don't eat fish, whıle you are drınkıng milk'), cf b Anb. Inș 229-30; Farrā', Ma'ānì 'l-Qur'ān. I, 33, quoted by Mubārak, 1963, 325 with further discussion; of also Carter, 1973, who tries to show that it is incorrect to attribute the term sarf in this sense to the Küfans exclusively Accordıng to hım Farrā' and Sibawaıhı (Kit 1, 424-7) to a large extent agreed as to the nature of this principle, which is called hiläf by Sïbawashi Later Basrian grammarıans rejected It, and it was, therefore, attributed to the Küfans On the sarf/lnläf Reckendorf, 1921, 462; de Sacy, 1829, 217-9, Mahzūmì. 1958, 293 sqq: Mosel, 1975, 57-8 
in a change of the root from its primary meaning to a secondary one. ${ }^{77}$

'Adala in its sense of 'to derive analogically from' represents the Alexandrian term parágein, as against the term tașrif (i.e., the Greek klisis), which is restricted to the inflection. In the Stoic-Pergamene system, on the other hand, klisis (tașrin) is used for every sort of derivation, including declension and inflection. ${ }^{78} \mathrm{~A}$ few examples of the use of "adala in Arabic grammar are: (Ibn Ginni) the form fu'al is derived from the form $f a^{i} i l$ by means of $u d \bar{u} l ;{ }^{79}$ (id.) the form $f a^{\prime} a l i$ is derived from the form $f a^{\circ} l a ;^{80}$ (Farrä') ağma' üna is derived from (ma'dūl an) ağma ${ }^{*}{ }^{81}$ (Ta'lab) șabür is derived from the verb sabira ${ }^{82}$ (Ibn Madā') the nouns which are derived from the participles. ${ }^{83}$ These examples are all in accordance with the Alexandrian use of parágein: they are all cases of derivation, not of declension or inflection. On the other hand, in philosophical grammar we find for instance with al-Fārābi that verbs (kalim) are changed ( $y u^{i}$ dalu bihāa), so that they become commands or prohibitions (amr aw nahy) ${ }^{84}$ Here we find "adl applied to the verbs.

The Arabic name for the first of the nominal cases is raf, i.e., 'lifting'. In 1889 Merx pointed out the similarity between this term and the Greek name for the first case, orthè ptôsis, but he did so not without reservation: 'Potestne credi hoc casu esse factum, et negari in seligendo nomine raf $u$ Arabes doctrinam Peripateticorum esse secutos, quam a commentatore aliquo Aristotelico didicerunt? Nihilo minus vero mihi nondum constat, nomen raf $u$ nihil esse nisi interpretationem vocis orthè vel eutheía, nam si raf $u$ graecum esset, etiam reliqua casuum nomina ex graecis processisse coniciendum esset, quod probari nequit'. ${ }^{85}$

In the first place we must remark that Merx attributed every similarity between Greek and Arabic grammar in the early period to Peripatetic influence; he did not look for similarities between living

77 b Gin Has 1, 52, 9-10.

78 Barwick, 1957, 34.

79 b Gin. Has. 3, 267, 9

so b. Gin. Has 3, 261, 6, cf Zağğ. Mağ. 223, 14. hadāmı (hurry up') is a derıvate of the same order as, for instance, 'umaru, which is derived from 'amır

$\$$ Farr. ap. Ta'l Mağ. 1, 98, 11

${ }^{82}$ Ta"l. Mağ 1, 316, 4.

83 b Madā', Radd, 100, 3; cf Arnaldez, 1956, 91.

84 Far Ihṣ. 14, 8

us Merx, 1889,152 
Greek grammatical practice and Arabic grammar. In the case of the names of the nominal cases we have a good example of the difference between the two influences, since the Aristotelian tradition forced its own names upon the Arabic translators and upon those philosophers who based themselves on Greek material, namely mustaqim for Greek orthós, and $m a \bar{i} i l$ for Greek enklinómenos. These are the terms used by Fārābi ${ }^{86}$ It is obvious that Fārābi did not adhere strictly to the Peripatetic doctrine, which considered the nominative as the basic form, and the rest of the cases as declension (ptôsis), but rather followed the Stoic tradition, which considered the nominative as the first of the nominal cases. ${ }^{87}$ This has been pointed out by Zimmermann, who may be right in attributing this departure from the Aristotelian tradition to the discussions by Greek commentators concerning this point. ${ }^{88}$ On the other hand, it is also possible that Fārābi heard something about Greek grammatical practice, possibly via the Arabic and Syrian translators, who were active at Baghdad during his lifetime. We have seen above that he sometimes uses elements from Greek grammar, which cannot be derived from translations of Aristotelian writings. ${ }^{89}$

For an explanation of the grammatical names of the nominal cases we cannot resort to the translations at all, but must base ourselves on the data from Greek grammar. We do not believe that it is possible - given the present state of our knowledge-to prove any connection between raf and orthè ptôsis. Merx is certainly right when he says that when there is a connection between the name of the nominative in Greek and Arabic grammar, we expect the same connection to exist in the case of the names of the other cases. His own efforts to prove that connection seem rather farfetched, ${ }^{90}$ so that the question remains undecided. The only additional observation we would like to make is of a very hypothetical character: all Arabic names for the cases taken together could give the picture of a noun being erected (marf $\left.\bar{u}^{\circ}\right)$, which is then pulled aside (mağrür), and finally brought down

${ }^{86}$ Far Sarh, 64, 15 (as synonym for $m a ̈ ’ l$ the term musarraf), Ibn Suwār, 365, 5 (only mustaqim as against musarraf). According to Zimmermann (Islamic philosophy, 1972 , 540, note 14) these terms were used only in the Baghdad school of translators.

87 Cf. Steinthal, 18902 , 1, 303-4; Schmidt, 1839, 59-60; Pohlenz, 1939, 169; cf the discussion in the scholia D.T., 230, 24-33, 546, $15-548,5$.

88 Zimmermann, Islamic philosophy, 1972, 521-2 referring to the discussion by Stephanos, 10, 22 sqq.

a9 $\mathrm{Cf}$ above, note 53, and chapter IIl A (Fārābī's division of the ḥurūf)

90 Merx, 1889, 152-3. 
(manșüh?), ${ }^{91}$ in other words the same metaphor as in the Greek ptôseis, which begin with the orthè and end with the plagiai ptôseis. ${ }^{92}$ We must concede, though, that the evidence is rather meagre. Perhaps the explanation of the Arabic grammarians of the names of the cases in terms of the articulatory movements needed for the pronunciation of the case-endings is correct after all. ${ }^{93}$

Although there seems to be no connection between the Greek and the Arabic name for the genitive, there is a similarity in functions. The genitive indicates the idâfa (adjunction, annexion), and the id̄alfa, according to Zağğàğì, has three functions: it joins something to its owner; it joins something to the person who has a right to it; it joins something to its genus. ${ }^{94}$ We are reminded by these three functions of the three names the second case may have in Greek grammar : ${ }^{95}$ the second case may be called ktètike (case of possession); patrike (case of fatherhood); genike (interpreted as 'general case', "case of the genus', "case of the root'). ${ }^{96}$

Nouns and particles may be said to be dependent (mu'allaq) on other words: ${ }^{97}$ the meaningful particle, for instance, is said to be always dependent. ${ }^{98} \mathrm{~A}$ second meaning of the word is "being in suspense, not yet terminated', when it is said about a sentence which has not yet been completed and still misses an essential part. ${ }^{99}$ In that case the term is almost synonymous with the term näqis (as against tämm) used by Ibn Ginni. ${ }^{100}$ Finally the word muallaq is also used for the creation of the words, which are said to have been 'hung up' on the things. ${ }^{101}$ Ibn Maḍā' explains the first meaning

91 For the lexical signification of the terms we refer to the Lisän al- $A$ Arah. ss vv . raf is the opposite of hafd (8, 129 right); garr is explained by the word gadh, $1 \mathrm{e}$, 'pullıng aside' $(8,4$ right 9$)$; but nas b means 'standing erect' (1, 760, left 12, cf. Shehaby, 1975,78 , note 7 ).

92 For the meaning of the Greek term ptôsı: Sittıg, 1931: Hiersche, 1955, of also Pohlenz, 1939. 169-7!.

93 E g. Zağğ. Iḍ., pp 93-4; Semaan, 1968, 19

94 Zašg. Id. 108, 10 sqq.; of b. Gın Has 3, 26, 9 sqq

95 E.g. scholia D T. 384, 1-7.

96 For a discussion about the meaning of the term genikè we refer to: de Mauro, 1965, appendice I (pp 206-8); also Pohlenz, 1939, 172-5

${ }^{7}$ Cf. Zağğ Lam 22, 8; b Kats. ap. Suy. Ham al-hawāmi, 1, 140 (quoted by Dalf, 1968, 251), b. Gin. Has 3, 107, 1-2; 3, 170, 2; 3, 256, 1, 3, 270. 10, with other forms from the same root (ta'allaqa, 'allaqa).

98 Mub ap, Zağğ Mağ. 222, 11

99 Māzınì ap. Suy Bugya, 1, 465, 7

$100 \mathrm{Cf}$ above, chapter II (the distınction between qaul and kalām)

${ }^{101}$ E.g by Ibn Hazm, Ihk 1, 261, 13 "ulliqa ala ... (to be created in order to signify ...). 
of the term, when he tells us that the grammarians use the verb a mala to indicate the word that governs a nominative or an accusative, but the verb allaqa to indicate the word that is connected with a genitive. He himself cannot accept the first verb, because as a Zāhirite he does not acknowledge any human action at all, and human action is implied by the use of the verb a mala, when we are talking about a grammatical subject or object. ${ }^{102}$ Ibn Maḍā' uses, therefore, 'allaqa in all cases, since this verb indicates only a statement about an established syntactic situation. ${ }^{103}$ In Greek grammatical terminology the verb artâsthai is used with the same sense as the first meaning of muallaq, namely 'to be dependent on', for instance by Apollonios Dyskolos. ${ }^{104}$ There are also expressions with the verb kremâsthai (to hang), which remind us of the second meaning of muallaq e.g., krématai ho lógos (speech is in suspense, is not yet complete). ${ }^{105}$

\section{THE VERB}

Three types of definitions may be distinguished in Arabic grammatical literature.

1. In the first place there is the morphological definition, which lists those morphological characteristics of the verb that mark it as different from the noun and the particle. Some of these characteristics are negative, e.g., the verb has neither dual or plural, nor a feminine gender ${ }^{1}$ some characteristics are positive, e.g., the verb may have a personal suffix attached to it, and it may be used in combination with temporal adverbs, such as 'yesterday', 'tomorrow', i.e., it can indicate time. ${ }^{2}$ Those definitions that mention positive characteristics

\footnotetext{
$102 \mathrm{Cr}$ below, chapter VIII, note 23

103 b. Maḍā', Radd, p 107

104 Apoll Dysk synt 24, 1-3; 72, 10, 120, 12, 421, 9, 463, 4

105 Cr. Liddell/Scott, s v.

${ }^{1} \mathrm{Cr}$ ap. b Fār Sāh. 52, 9 [A 37] the verb is that which is prevented from (recelving) the dual and the plural', b. Anb Ins. 40, 18-9 [A 38] 'the verb cannot be made femınıne, only the noun'. For the term ımınä' (umtuni'a): cf Mubarrad's definttion of the noun, above, chapter III B, note 5 . Note that it is the subject of the verb that is made dual, plural, feminine, not the verb itself

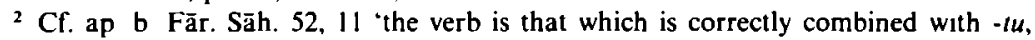
e.g. qumtu (I stood up), dahabiu (I left)' [A 39]; 1b. 52, 13 'the verb is that which is correctly combined with amsı (yesterday) and gadan (tomorrow)' [A 40]; cf. Zağğ. Gum. 21, ult. - 22, 2.
} 
often contain the words hasuna an ... (it is correct to ...); these words seem to be typical of the definitions of al-Ahfas. ${ }^{3}$ Sibawaihi gives the indication of time as one of the characteristics of the verb. ${ }^{4}$

2. In the second place, there is a group of definitions which are not concerned with the characteristics of the verb or with its function, but with the nature of what is signified by the verb. These definitions have been influenced by Aristotle's definition; they will be discussed in the chapter about the influence of logic. ${ }^{5}$

3. Finally, there are definitions which define the syntactic function of the verb: it is always used as a predicate, but it cannot have a predicate itself. That verbs serve as predicates in the sentence, had already been mentioned by Aristotle; still, we believe this type of definitions to have been formulated under the influence of Stoic theories. The definition of the verb as an attribute which cannot receive any attributes itself (șifa gair maușüf) stems from a very old non-aristotelian tradition which regards the verb not as something that denotes an action as well as the time of that action, but as one of the two components of a complete sentence, namely the predicate.

Subject and predicate are called by Fārābì maușūf and șifa. ${ }^{6}$ He also mentions as synonyms musnad ilaihi/musnad bihi and muhbar "anhu/ muhbar bihi, habar. The first set of synonyms is used by Sibawaihi, ${ }^{7}$ but the subject is normally called by him mubtada'. The second set is found in the definitions of noun, verb, and particle in the Bașrian tradition: noun is 'what can be used as a predicate and can receive a

${ }^{3} \mathrm{Cf}$ above, chapter III B, note 26.

4 Cf. above, chapter III A, note 25. In Greek grammar Dionysios Thrax defines the verb according to its morphological properties as follows. 'The verb is an undeclined word which can receive tense, person, and number, and which expresses an action (enérgeı ) or a passion (páthos)' $(46,45)$ [G 26] This definition was imitated by other authors, including Apollonios Dyskolos, who adds, however, that morphological properties are not essentual for the verb: the most characteristic feature of the verb is that it sıgnifies an action (prôgma), the rest of the propertıes is accidental (sumparhepómena). Only thus can we include the infinitive in the verbal system. Cr Steinthal, $1891^{2}, 2$, 267 sqq.

5 Cr. below, chapter VII.

6 Far. Alf. p. 57, the two terms are also used by $\underline{H}$ wār. Maf. 142, 11 sqq. Gazzāi tells us that this set of terms for the subject and the predicate was used especially by the theologians, Mihakk, 23, 28; Qistās, 67/62; cf. Brunschvig, 1970, 163 (21); Gätje, 1974, 163-4 On predicatıon as the central part of traditional grammar: Gabučan, 1971, 26 sqq.; Cohen, 1970.

7 Sib. Kit. 1, 7, 13-21 ; cf. Rāzì, Maf. 1, 36, 9 
predicate itself'; verb is 'what can be used as a predicate, but cannot receive a predicate itself'; particle is 'what can neither be used as a predicate, nor receive a predicate itself ${ }^{8}$ The function of the verb as the predicate of the sentence is already expressed in "Ali's' definition: 'The verb is what is used to give information'. ${ }^{9}$ Habar came to be used in Arabic syntax as the terminus technicus for the notion of 'predicate'.

Arabic syntax divides sentences into nominal sentences (ğumal ismiyya), and verbal sentences ( $\dot{u} u m a l ~ f i l i y y a)$. The essential parts of a verbal sentence are the 'do-er' $\left(f \bar{a}^{2} i l\right)$ and the 'action' $(f i l) .{ }^{10}$ The nominal sentence contains a 'subject' (mubtada'; muhbar 'anhu), and a predicate (habar). The term habar is also used with the meaning 'proposition': it is then defined as 'that which can be declared truth or falsehood (alladi yatatarraqu ilaihi 't-tasdiq wa-'t-takdib). ${ }^{11}$ This definition is identical to the Stoic definition of axioma. ${ }^{12}$ Ploutarchos tells us about the proposition: 'Is it because the classical authors used to call what was then termed prótasis, and now axiôma "the first sentence", because it is the first thing uttered by us, (which shows us) telling the truth or lying? This first sentence contains a noun and a verb; the former is called ptosis by the Stoic logicians, the latter katègórema'. ${ }^{13}$ The predicative part of the proposition, the katègórè$m a$, is then defined as 'That which is said about something', or 'A composed meaning (prâgma suntaktón) about something singular or

${ }^{8}$ Ap b Anb Ins 2, 13-8; of Rāzi, Maf 1, 32 pen - 33, 1, the same kind of definitions for the noun, the verb, and the particle were used by the Coptic grammarians, of Bauer, 1972, 68 The Basrian grammarians used these definitions as an argument for the priority of the noun, of below, chapter VII, note 107. On the isnäd. Zam Muf 13. 2 (predication (isnäd) necessarily consists of (wo parts, the musnad and the musnad Ilaihı).

9 Ap b Anb Nuzha, 4, 10 (al-fi'l mā unbia bihl).

${ }^{10}$ For these terms an Indian origin has been suggested (kartr, karman), cf. Diem, 1970, 318, note 1, on the other hand, we find in Greek grammatical literature ho energôn and ho energoumenos with approxımately the same sense as Arabic $\bar{a}^{\prime \prime} \| l$ and mafül, of Apoll Dysk. synt 139, 7; 344, 12-3, 396, 3 Enérgéa is already translated by $f i{ }^{\prime}$ in Qustā ıbn Lūqā's translation of the Placita Phılosophorum, ed. Daiber, p. 69, 9 On the lerms $f \bar{a}^{\prime} l /$ maf $\bar{u} /$ used in another sense in a definition of the noun, of above, chapter III B. note $\mathbf{3 6}$

"Gazz Maq 19,11. in grammar'b Gin Has 1, 186, 12-3; b Anb Ins 54, 10-1; 61, 25. Mub Muqt. 3. 89; cl van Ess, 1970, 30 and note 40; also b. Fār Sāh 150, 7: definition of the ahl an-nazar

12 Sext Emp adv math 1, 70 (= SVF 2, 187), Diog. Laert. 7, 66 (=SVF 2, 186); in logic axioma is translated by qadiva, of van Ess, 1970, 30 and note 40; Zimmermann. Islamic philosophy, 1972, 536

13 Plout quaest plat X, p. 1009 C [G 27] 
plural', or 'A deficient meaning (lektón ellipés, i.e., an utterance which does not form a complete sentence) constructed with a nominative in order to form a proposition'. ${ }^{14}$ We suppose that the Greek terms agoreuomenon (that which is said) and suntaktón (composed, constructed with) are at the basis of the Arabic terms muhbar and musnad, respectively. This would explain the resemblance between the definitions of 'proposition', as they are given in the Greek as well as in the Arabic world, and also the existence of several sets of synonyms. One could object that the Greek word katègórèma denotes a verbal predicate, whereas in Arabic habar is precisely the nominal predicate (in the Arabic sense of the word: in zaid kataba (Zaid wrote) we would call the second word a verb, but in Arabic grammatical terminology it is called a nominal predicate, or rather, the predicate of a nominal sentence ${ }^{15}$ ). This problem may be solved, when we take into account the Greek conception of the verbal predicate, which considers diôn peripateî (Dion walks) equivalent with diôn estì peripatôn (Dion is walking). This construction was borrowed by the Arabic grammarians and, adapted to the structure of the Arabic language, it became a nominal sentence, where the predicate was the predicate of a nominal sentence. For verbal sentences a new set of terms was invented. ${ }^{16}$

The term used for the subject of the nominal sentence is not the Stoic term ptôsis, but a new term, mubtada'. This 'first position' (ibti$d \vec{a}$ ) does not indicate the first place of the subject in the sentence, but it is the 'first position' of the noun itself, i.e., the nominative: 'The mubtada' is the noun in the first position, before the existence of any expressed grammatical regens. We use the expression "first position" in order to distinguish between that which has the first place in the real sentence, even though it should come later, and that which has a right to the first position, even though it comes later in the real sentence by a process of extension (ittisäa)'. ${ }^{17}$ According to

${ }^{14}$ Diog Laert 7,64 (= SVF 2, 183) [G 28]

15 Cr Cohen, 1970 Zimmermann (Islamic philosophy, 1972, 542, note 37) points out that a Greek sentence Philon hugıainet (Phılon is healthy) would be translated into Arabic as fulan sahih. $1 \mathrm{c}$ a sentence with a nominal predicate.

16 But cl above. note 10.

${ }^{17}$ Rumm ap Mubārak, 1963, 312, 13-6 [A 41] On the difference between muhtada. and $\mid \vec{a} \prime l \cdot b$ Gin. Has 1, 196, 1-14 Mubarrad's usc of the term thidà is rather different; he says (Muqt 3, 89) about the ihtıda' that it is 'what is called by the grammarians the article $(a / l /-l a \bar{m})$. According to Mubarrad, in an expression such as qäma zard (Zand stood up). If we want to predicate somethıng about Zaid, we say $a l-q \bar{a}^{\prime}, m$ zand (the stander-up is Zaud) and this process is called ıhudä' ('?). 
Sibawaihi's explanation the mubtada' is the first of the nominal states $(a h w a \bar{l} l) .{ }^{18}$ Greek grammarians, too, held that the nominative is the principal case, and Gregorios of Corinth emphasizes that the subject should occupy the first place in the sentence, theoretically at least: 'Do not think that the noun necessarily occupies the first place in the construction of the sentence, and the verb the second place, and then the rest. On the contrary, the order of the words is left to chance ..., even though it is in the nature of the words that the noun should be put first, being the substance, and that the verb should follow, being the accident, and that the rest of the words should be placed after them ....' ${ }^{19}$ We will not go into the matter of the Syriac equivalents of mubtada' and habar, šurrāya and tebbä, which are used by Barhebraeus, since these terms may be the result of Arabic influence, especially by Zamahšarī's Mufasṣal. ${ }^{20}$

It is important to note that there also exists in Arabic literature a set of terms that correspond to the Aristotelian terms for 'subject' (hupokeimenon) and 'predicate' (katègoroúmenon), namely maud̆ $\bar{u}^{\prime}$ and mahmül. ${ }^{21}$ The existence of two sets of terms, one used in grammar and one in logic-this is stated explicitly by Hwārizmī and Gazzāli ${ }^{22}$ confirms the fact that the original grammatical tradition was not influenced by Aristotelian logic, but by the contact with living Greek grammar, which bore the traces of Stoic influence.

It should be mentioned that some grammarians held that a verb sometimes does have a predicate of its own, for instance in expressions such as daraba huwa fil (hit is a verb). The arguments for this 'predication about the verb' (ihhbār 'an al-fíl) are rejected by Rāzī. ${ }^{23}$ Another question concerns the position of the temporal and local adverbs (zurüf), which according to some opponents fall under the definition of the verb, since they cannot have a predicate. Zağǧăǧi

${ }^{18}$ Sib. Kit 1, 7, 17, cf b. Anb. Ins. 15, 2

19 Greg. Cor 6-7 [G 29], cf. scholıa D T 548, 27-9

20 Merx, 1889, 147, 246, Tarazi, 1969, 115

21 Aristot categ. 1 a-b, the Arabic terms are given, for instance, by Far. Sarh. 17, 12; Howār Maf. 142, 11 sqq , Gazz Mıhakk, 23, 28, Qistās, 67/62 (cr Brunschvig, 1970, 163 (21)), Sığıstānì ap Tauh Muq 284, 9, cf also Fleısch, 1961, 25, n. 1, Zımmermann, Islamıc philosophy, 1972, 534

22 Hwār Maf 142, 11 sqq . Gazzālī explaıns that mubtada/habar is typical for grammar, mausüf/sı/a for theology, and muhbar 'anhu/mahmül for logıc, in law mah$\mathrm{kum} / \mathrm{hukm}$ are used for the notions of subject and predicate, of the references in the precedıng note As for sita, according to Diem, 1970, 313-5, it is used in Sibawaihi's $K ı \bar{a} h$ as a general term for attributes, not for the adjectıve alone.

23 Rāzí, Mar I, 33, 6 sqq 
denies this: the words makān (place) and zamān (time), implied by the adverbs aina (where?) and matä (when?), can receive a predicate. "Abd al-Qāhir argues in the same way against the objection of the opponents: 'When we say "noun is something about which you can predicate something", what we intend to say is "noun is that about whose meaning you can predicate something" ...' ${ }^{24}$ Aina and matä fall, therefore, under the definition of the noun, since it is possible to predicate something about their meaning.

After having examined the definition of the verb, we will look into two characteristics of verbs, namely the indication of tense, and (in)transitivity; finally, we will discuss the relationship between the masdar/infinitive and the verb.

Grammatical tenses are not the same thing as physical time; still, the two are related. Time (chrónos) is defined by Chrysippos as 'interval (or: extension) of the movement of the cosmos' (diástèma tès tou kósmou kinèseôs); ${ }^{25}$ it is one of the four incorporeal things (asômata). ${ }^{26}$ With the 'void' (kenón) it shares the property of being infinite in two directions, the past and the future. ${ }^{27}$ The present moment is only an intersection of two infinite times, itself being without dimensions and without existence from a geometrical point of view. ${ }^{28}$ But on the other hand, the present time is the only one which really exists (huparchein), whereas past and future only exist as constructions of the mind (huphestánai). ${ }^{29}$

Aristotle wrote about the precarious existence of the present time, which cannot exist in any physical sense. ${ }^{30}$ This implies that actions

24 'Abd al-Qāhir ap. Rāzī, Maf 1, 33, pen 34, 2 Note the discrepancy between Zağğăğis denial, Id 53,7-12, and his own objectıons to the definition of the noun by al-Aḥfaš Sa'ìd ıbn Mas'ada, Id 49, 14 sqq

${ }^{25}$ SVF 2, 510 Cl Christensen, 1962, 25-6, Risı, 1969, 273-88; Goldschmıdı, 1953. Sambursky, 1971, 98-108. Cr. ın Arabıc literature the definıtıon given by Abū Sulaımān as-Sığıstāni, ap Tauh. Muq. 278, 16-7, and the definıtıon mentıoned by Ibn al-Anbārî, lns 63, 23-4 'tıme is the movement of the stars' (az-zamän harakat al-falak), and by Muhammad ibn Zakariyyā ar-Rāzi, Opera Phılosophıca, 1, 243, 14-6 'tıme is the duration of the existence of the stars' (az-zamān mudda nugīud al-falah); cf Nader, 1956, 188-9, Jadaane, 1967, 214-5

26 Together with topos (place), kenón (void), and lekion (meanıng), SVF 2, 331

27 SVF 2, 509; 520.

28 A point also made by Hebrew grammarians, cf Chomsky's notes on Kimhi's Mikhlol, p. 361 , n 628.

29 SVF 2, 164, 26-7.

30 Aristot. phys. 233 b 33 sqq ; natural. auscult. 219 b-220 a; cf Steınthal, $1890^{2}$. 1, 312 sqq For Aristotle's theories concerning tume: Conen, 1964. After Aristotle became known in the Arabic world the concept of tume was dealt with in a more scientific way, by means of the distinction between time in a broader and in a narrower 
in the present time cannot exist, and that verbs cannot possess verbal forms of the present tense. However, besides time in the strictest sense of the word, there exists another time, which is defined by Fārābi in the following words: "If we take the time with a definite distance in the past from the present moment, which is the end and the beginning (sc. the present time conceived of as an intersection of two infinite times, itself without dimensions), and we join it with the same time in the future, and if their distance from the present moment, which is the end and the beginning, forms one single distance in past and future, and if they are taken together, then this time is the present time'. ${ }^{31}$ According to Fārābì, philosophers use the word 'now' in both senses, i.e., in the strictest sense and in the derived sense, common people know only of the second sense, ${ }^{32}$ whereas grammarians base themselves on the first sense exclusively in concluding that verbs in the present tense do not exist. ${ }^{33}$ In Fārābī's definition present time is actually the contraction of the last part of the past and the first part of the future. This is expressed in grammatical terms by Priscianus, when he describes the present tense of a verb: 'We use to call this tense praesens, because it holds together and it unites, as it were, in one point the junction of the past and the future tenses, without any intercision ..., like when I say in the middle of a verse "I write a verse", when the first part of the verse has already been written down, and the last part is still lacking. I use the verb in the present tense, saying "I write a verse", but it is imperfect, because part of the verse is still lacking'. ${ }^{34}$ In fact, this is the original theory of Chrysippos: the present time consists of two parts, one of which is past, and the other future. ${ }^{35}$

This present time may be long or short, for it is possible to say 'the present year', 'the present day', or 'the present minute'. ${ }^{36}$ The

sense As-Sı̆̆ıstānī (ap Tauh. Muq 278) and Ibn al-Anbãrì (Inș. 103) use the terms zamān mullaq and zamōn basit (or muayyan), theır source was probably Fārābī's Sarh al-'Ibära (Sarh, 40, 1 - 42, 26).

31 Far. Sarh. 41, 2-4 [A 42]

32 Ib. $40,25-41,2$.

33 Ib. $40,17-8$.

34 Prisc instit. 8, $52(414,24$ - 415, 6): Ergo praesens tempus hoc solemus dicere quod contineat et coniungat quasi puncto aliquo iuncturum praeteritt temporis et futurt nulla intercisione interventente... ut, si in medio versu dicam 'scribo versum' priore eius parte scripta, cul adhuc deest extrema pars, praesenti utor verbo dicendo 'scribo versum', sed imperfectum est, quod deest adhuc versui, quod scribatur.

${ }^{35}$ This theory is transmitted by Plout. de comm. not. cap. 41 sqq.; cl. SVF 2, 517.

${ }^{36}$ Far. Sarh, 41, 8-9, cf. scholia D T. 559, 48: 'They say that Dionysios used 
present time is a gradual transition from the future into the past. ${ }^{37}$ In this time the action takes place simultaneously with the expression of that action in speech: 'The present time comes into being during the words of the speaker', says Zağğà ${ }^{1} \overline{1},{ }^{38}$ thereby agreeing with the scholiast on Dionysios Thrax, who puts it like this: 'It (sc. the present time) combines the existence of something with its expression' ${ }^{39}$

Sibawaihi's analysis of the Arabic verbal system revealed two verbal forms: a perfect (qatala), and an imperfect (vaqtulu) (and an imperative $(u q t u l)$ ). He described these forms in the following way: 'As for the verbs, they are patterns taken from the expression of the events of the nouns, and they are constructed to (signify) what is past, and what is to come, and what is being without interruption. The structure of what is past is dahaba, sami a, makuta, humida; the structure of what did not yet occur is, ... when you are telling something yaqtulu, yadhabu, yadribu, yuqtalu, yudrabu, and so is the structure of what is being and is not yet finished, when you are telling something'. ${ }^{40}$ Remarkable in this division is the fact that, although there are only two verbal forms, and although these forms do not indicate the time of the action, but its aspect, Sibawaihi nevertheless designed a system with three tenses. Merx attributed this to the influence of the Persian translations of Aristotle's De Interpretatione $^{41}$ in combination with the fact that Sibawaihi was of Persian

\footnotetext{
"tımes" in the sense of "distances of time", like when we divide the tıme into years, months, days, and hours. That is why he calls it "present tense" (enhestôs), namely, as If it has the length of a year, or a month, or a day, or an hour, for we say "the present year, month, day, hour" [G 30]; of Choirob. 2, 12, 2 sqq (the platukis chronos of the grammarians), also Joh. Phıl. comment. in Aristot. phys. 703, 16. On the grammatical present tense . scholia D.T. 248, 13 sqq. ; 249, 3-8; 403, 3; 404, 26-8, 559, 4 sqq. , cf also Ploutarchos' criticism on Archedemos, de comm. not cap. $41=$ SVF 3, 263, 14

${ }^{37} \mathrm{Cf}$. Prisc. Instit. 8, 51-3 (414, 9-415, 10): ' . as time flows continuously like a river, it can hardly have a (fixed) point in the present ume' (.. cum enim tempus fluvi more instabilt volvalur cursu, vix punctum habere potest in praesentı), cf. Zağg Iḍ 87 , 5-6 'bit by bit' (aw'walan awwalan).

30 Zağğ. Id. 87, 3 (al-mulakawn in fi häl huṭāh al-mutakallım); Sīrāfĩ defines the three grammatical tenses with sımılar terms (Sarḥ al-Kitāb, 1, 12, as quoted by Mubārak in his edıtion of Zağğāăì's Idâh, p. 87, n 1).

${ }^{39}$ Scholı D T. 404, 27-8 (háma gàr tôt légesthaı échei kai tó eínaı); cf. Chorrob 2, $11,34-12,1$.

${ }^{40} \mathrm{Sib}$. Kit 1, 2, 2-5 [A 43]. Merx' analysis of this text, 1889, 142, can hardly be correct: Sibawaihi most certainly did not mention the imperative as an example of what is being done and is not yet finished! Sibawaihi's 'definition' of the verb cf above, chapter III A, note 25 ; also : Troupeau, $1962^{\mathrm{b}}$.

41 Aristot. de interpret. 113 b 17, as compared with the translation given by Paulus Persa, ed. Land, IV, 15, 112, in the preserved Syriac translation of the Persian original
} 
origin. ${ }^{42}$ On the other hand, awareness of three physical times is not unique, and Sibawaihi may very well have adapted on his own initiative the Arabic verbal system to these three times. What is more, he does not give to each of the three times its own name, but uses, following the structure of the Arabic language, only one name for the present and the future tenses together. The perfect 'tense' is called by him mädi, i.e., 'what has gone, what is past'. In this case, there may be a connection with the Greek pareleluthos, but not in the case of the imperfect 'tense', which is called mudarri', i.e., 'resembling' (sc. the nouns, or the active participle $f\left(\bar{a}^{2} i l\right)$, since the verbal forms of the imperfect have almost the same endings as the nouns, or since the syntactic function of the imperfect resembles that of the active participle. $^{43}$

The term mudāri is used by Sibawaihi not only to indicate the resemblance of the verbal modes to the nominal cases-which is evident in Arabic-, but also the fundamental equivalence in function of the imperfect verb and the active participle: zaid la-yaf alu (Zaid really does) and zaid la-fä $i l$ (Zaid is really doing) have the same construction, and amount to the same thing. Another analogy between the imperfect verb and the active participle is that verbs may receive the particle saufa, just as participles may be determined by the article: in both cases, according to the Arabic grammarians, the function of the added article is to make the word to which it is added definite. ${ }^{44}$ This 'famous resemblance' (mudūara'a mašhūra $)^{45}$ was held for a long time by all grammarians, although the Bașrians and the Küfans interpreted it differently: according to Ibn al-Anbārī, ${ }^{46}$ the Kūfans held that the imperfect verbs had a certain right to declension, because they, like the nouns, are used to convey different meanings (ma'ani muhtalifa) $;{ }^{47}$ the Bașrians, on the other hand, granted the right of

(probably this Paulus Persa is identical with Paulus of Nisıbis, who died in 571 A D, cf. Baumstark, 19682, 121, Georr, 1948, 15-6), quoled by Merx, 1889, 142

42 Merx, $1889,142$.

43 For muḍari $\cdot$ Mahnzūmì, 1958, 238 : Diem, 1970, p. 319, note. Apparently, Zağğăḡī avolded the term mudäri : whenever it crops up in the argument of an adversary (e.g , Id. 107, 9 sqq., Id 87,13 sqq. : fi kutubihım') he starts to explain its meaning

${ }^{44}$ Sib Kit 1, 3, 12 sqq ; cr. Hegazi, 1971, 55-9

45 Zağg Iḍ 87, 14.

46 b. Anb Inṣ 224, 21 - 225, 25 (mas'ala 73)

47 Probably not in the sense that homonymous verbs exıst, as Zaǵğāği trıes to make out, Id. 87, 13 sqq, but that verbs indicate different meanings-possess different syntactic functions-, just as nouns are subject to changes which serve to express the different functions of the nouns (määni), e.g. Iḍ 69, 6 sqq. But of Zam Muf 109, 8. 
declension to the imperfect verbs in accordance with their place within the grammatical system, where they resemble the nouns in three respects (wugiuh) ${ }^{48}$ These three respects are: the analogy between the article and the particle saufa; the fact that both the imperfect verb and the active participle may receive the particle $l a-$; and the fact that imperfect verbs may replace the active participles in many sentences. Essentially, these are the same points as those mentioned by Sibawaihi. ${ }^{49}$ Thus, according to the Bașrians, imperfect verbs are declined because they themselves resemble the nouns; according to the Kuffans, a certain category of the verbs, namely the imperfect verbs, is declined, because verbs bear a general likeness to nouns.

The comparison of the verbal moods to the nominal cases is not as original as it appears to be at first sight. The same comparison is made in Greek grammatical literature, though not because of a resemblance of verbs to nouns, but 'nach dem beliebten Parallelismus zwischen den verschiedenen Gebieten der Grammatik'. ${ }^{\circ}$ Zağğāḡì's remark that verbal forms may be used for more than one meaning, just like the nouns, may be compared to the remarks of Apollonios Dyskolos concerning the sumpátheia, i.e., the phenomenon that one form takes the function of another form. ${ }^{51}$ As for the equivalence in function of the imperfect verb and the active participle, we may point to the Greek doctrine, which states that a form such as louei (he washes) is equivalent to esti louion (he is washing), as is customary in logic. According to the Küfans the active participle constitutes the third tense of the verb, the present tense; the participle is then called the $f i^{\circ} l d \bar{a}^{\prime} i m .^{52}$

It does not seem very likely that the Arabic term mudāri was the result of the influence of the Syriac term zavna de-damya, as is asserted by Tarazi ${ }^{53}$ it seems more probable that the influence was the other way round, since the Syriac term is of a much later date.

48 For this term: Well, 1913, 22 sqq

49 Also b Anb Lum 56, 4 sqq., Asr 12, 21 sqq

50 Steınthal, $1891^{2}, 2,296$, schoha D T. 246, 27-8; 399, 22-4; Apoll Dysk. Tragm pp. 86-7; Theod. 52, 4 sqq.; Choirob. 2, 104, 26 sqq.; Macrobıus, diff. 611, 36 Keil; Prisc instıt 8, 63 (421).

51 Apoll Dysk adv 202, 2-15. The possibility of one word with two different meanings was denıed by some Arabic grammarıans, cf. Suy. Muzh 1, 237-8; b. Gin Haș. 2, 308, 9-11

si Cf. Mahzūmi, 1958, 238-4l; also the refutation by Sīrāfi in his commentary on the Kitāh, 1, 493, as quoted by Mubārak in his edition of Zağgāāī’s Iḍăh. p. 86, note 1 .

53 Tarazi, 1969, 116. 
We have stated above that we do not believe that there is any cogent reason to assume an influence of Aristotelian logic in order to explain the occurrence of three tenses in Sibawaihi's analysis of the Arabic verbal system. Such an influence could, however, be supposed in the case of later grammarians who distinguished between three tenses of the verb, each with its own name: mādi, hăl, and mustaqbal. But because of the fact that this system was used in Arabic grammar before the first translations from Greek into Arabic, we prefer to assume a direct influence of Greek grammar, which should explain the transition from Sibawaihi's terminology (mâdi-mudârí) to the new terminology with three names for three tenses (mädi-hăl-mustaqbal ${ }^{54}$ ). Probably, the Syrian grammarians had something to do with this: in Syriac grammar the names for the three tenses of the verb are evidently calques of the Greek names, zavnā da-'bar (= parelètuthôs), zavnā $\underline{d}$ e-qa'em (= enhestôs), zavnā da-'tid (= méllôn). ${ }^{55}$ In Hebrew grammar the term zemān 'ömēd-also a calque of the Greek enhestôs-is used to translate the Arabic häl. ${ }^{56}$ Ibn Ganāh tells us that verbs have two tenses, namely hōolêf $(=$ parelèluthôs $)$ and 'ātid $(=$ méllôn $){ }^{57}$ We may have one instance in Arabic logical literature of the term kalima qa'ima being used to indicate the verb in the present tense, namely in Ibn Sinā's Sarh al-'lbāra: 'The situation of the inflected (mușarrafa) and the present ( $q \bar{a}^{\prime} i m a$ ) verb in the language of the Greeks is that the present verb is that which indicates the present time (hädir), whereas the inflected verb is that which indicates one of the two (other) times'. ${ }^{58}$ Note that the Greek term enhestôs came in use only a long time after Aristotle, namely in Stoic grammar. This supports the thesis of contact between Arabic grammar and living Greek grammar, where enhestôs was used after the example of the Stoa.

Grammarians may object to the reality of the present tense with arguments couched in physical terms, ${ }^{59}$ but when it comes to the question of the hierarchy of the three grammatical tenses, these objections disappear: speech is ruled by reason, and therefore, order and regularity should be found in every category, if only you look for

${ }^{54} \mathrm{Cr}$ Gesenius/Kautzsch, 190928, 132 n Muntazar (expected) is another name for what is normally called mustaqbal Both terms could translate the Greek term méllon (Zağğ Id $85,3,87,4,108,18$ in combınatıon with munqadi, perfect tense)

s Mcrx, 1889, 17, 26, Tarazì, 1969, 116

so Bacher, $1970^{2},(195)$

57 Ibn Ganāh, Sēfer harrıqmā, 41, 23

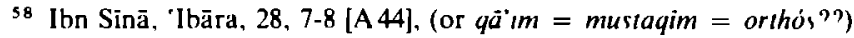

${ }^{59}$ E g Zağğ Id p 86 
it; moreover, speech is an image of reality, and there are, therefore, three tenses, just as there are three times. Their hierarchy is determined by the hierarchy of the physical times. Zağğāğì, for instance deduces from the chronological order of non-existence, existence, and past existence the classification of the verbal tenses: future-presentpast. ${ }^{60}$ He probably follows the doctrine of his teacher, Zağga àği, who held the same theory, and had a famous controversy with Abū Bakr ibn as-Sarrāğ on this subject. ${ }^{61}$ Ibn as-Sarrāğ thought that the present tense was the first verbal tense; his arguments are mentioned by Sìrāfî, who does not mention Ibn as-Sarrāğ by name, but evidently thinks of him, when he deals with the controversy on this subject. ${ }^{62}$ Zağğāğì's point of view is also mentioned by Suyūtị, and apparently it was the point of view of the majority of the grammarians. Ibn Ganāh, the Hebrew grammarian, tells us in his Kitāb al-luma that 'the Arabic grammarians' consider the future tense the first verbal tense, since every action must first be future, before it can be present, and then past. ${ }^{63}$

The same problem is dealt with in Greek grammar. In the scholia we often find the theory expressed that the present tense is the most important of the verbal tenses, since it is the stem of the verb (théma rhematos), a morphological argument that is, of course, absent in Arabic grammar. The scholiasts also say that every past tense once was a present tense; this resembles the argument mentioned by Zağğāği in the $\bar{l} d \bar{a} h .^{64}$ Sophronios summarizes the arguments in support of the possible theories concerning this point: ${ }^{65}$ a) present-past-future (not identical with ibn as-Sarrāğ's theory, because he places the future immediately after the past); b) the past is the first of the verbal

60 Zdğğ Id p 85

61 b Gin Has 2,31, 1-2

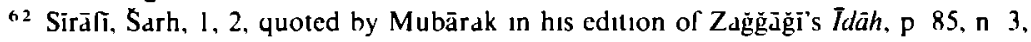
unfortundely only in part, without the arguments used by Sïāfī

${ }_{63}$ Bacher, 1970², 139 and notes 3-5, cf also b Anb Ins 105, 13, Suy Ašbāh, 1, 54

44 Scholia D T 249, 9-12, 403, 33 sqq . 559, 10-3, also Apoll Dysk synt 16, 1-2

65 Sophr 4I3, $32-414,7$ 'First comes the present, second the past, and third the future tense, but others say that the future tense should be put first, since first something is going to happen, then it happens. and then it is past, others prefer the past tense as the first tense, since past things happened before present things , but according to another theory, the present tense comes first, because it is visible and evident [G 31] Sophronios' arguments for the present tense resemble Ibn as-Sarrāğ's words 'The imperfect (mudärí) has the first position in the mind prior to the past' (al-mudäri ashaqu ruthatan fi' n-nafs mm al-mädi), ap b G̈ın Has 3.105. 10, cf 1b 3, 331. 13, obviously because the present tıme is "before our eyes", here mudari" denotes the present time, cf the quoldtion from Sīāfi (above, notc 62). who uses häl 
tenses (this theory existed in Arabic grammar, according to Nağğăr ${ }^{66}$ ); c) future-present-past. The third theory mentioned by Sophronios is the theory which was held by the majority of the Arabic grammarians, who defended it with the same arguments as the Greek grammarians: first something is going to happen, then it happens, and then it is past.

In later Greek grammar the process by which verbs are connected with their objects received the name metábasis or diábasis (in Latin grammar transitio). This term denoted the extension of the action of the verb to an object. This concept of 'transition' fits in with the point of view we find in later Greek grammar about the role of the verbs: verbs are no longer regarded as logical predicates in the sentence, but rather as names of actions: the verb ceases to be the kategoroumenon, ${ }^{67}$ it is now the ónoma tồ prágmatos. Metábasis, diábasis are found for instance in the writings of Apollonios Dyskolos, ${ }^{68}$ as well as in the scholia on Dionysios Thrax, ${ }^{69}$ and in Byzantine grammar. ${ }^{70}$ In Syriac grammar there existed a term mšanyānä for the transitive verb with approximately the same meaning as the Greek term metábasis ${ }^{71}$ in Hebrew grammar we find the term mit abberr, which also corresponds to the Greek term. ${ }^{72}$ Both terms, though, may be calques of the Arabic term. Arabic grammar used the term muta addi and its negative gair muta'addi (as well as the corresponding substantive ta addi or $a^{\prime}$ diya) for the concept of transitivity and intransitivity. ${ }^{73}$ The importance of these terms may be deduced from the fact that Sibawaihi devotes to this subject no less than ten chapters at the beginning of his Kitäb. ${ }^{74}$ Considering the resemblance between the Greek and the

\footnotetext{
on Nağğàr .n his edition of ıbn Gınnīs $\underline{H a s ̣ a ̈ ' s, ~ 2, ~ 31, ~ n ~ 1, ~ u n f o r t u n a t e l y ~ w i t h o u t ~}$ references

${ }^{67}$ For this term cl. above, note 21

${ }^{68}$ Apoll Dysk synt 402 sqq, pron $45-7$, active and passıve verbs'synt 394 sqq $\mathrm{Cf}$ also Schneider's index s.v. diá/metáhasıs

"9y Scholia D.T 89, 3 rhèma ametábaton vs rhèma en metábaset

70 E g a text ascribed to Gregorios of Corinth, ed. Donnet. 315, 1, 3 etc

71 Tarazi, 1969, 116. Merx, 1889, 253.

72 Bacher, 1970², 195, antepen

${ }^{73}$ Ibn Hıšam (Awd 2, 260) uses qāsır (faılıng) for gaır muıa'addi, for which we also find $\dot{g} a ̈ m u d$, e $\mathrm{g}$ b Gın Has 2,215, 20,2,349,2. Gämid is an interesıng lerm; it always indicates something simple as against something more complicated it may desıgnate substantıves vs adjectıves (Suy Iq t 72. 8. Rāzi, Maf. 1, 44, 6), a sımple noun vs a derıvative (de Sacy, 1829, 329, 356), a not-ınflected word vs an inflected one (b Anb. Ins 57, 22, b. Gin Haș 1, 37, 10 (ğamuda), Ta'lab ap Zağğ Mağ 350, 8) Because of its concrete meaning ('thıck', 'frozen', 'solıd') we would assume it to be a calque of a foreign word, but we have not been able to find a Greek equivalent.

74 Sib. K11 1, 13-26
} 
Arabic terms - the Arabic root ' $-d-w$ means 'to cross, overstep'-we suppose that the Arabic terms are calques of the Greek metábasis, metabatikos, borrowed by the Arabs at an early date through contact with living Greek grammar. The basic conception implied by the use of this term is common to both grammars, namely that the action of the verb passes on, is extended to the object. ${ }^{75}$

One of the hotly debated issues in the discussions between the Bașrians and the Küfans was the relation between the verb and the masdar: the Bașrians held that the masdar was the origin of the verb, whereas the Küfans believed that the verb was the original form, from which the masdar is derived. Ibn al-Anbāri deals with the arguments of both parties in the 28th problem of his Inșaf,${ }^{76}$ and the problem is mentioned by other authors as well. ${ }^{77}$ Traces of the discussion are even found in Hebrew grammatical writings. ${ }^{78}$ The discussion concerning the arguments pro and contra was garnished, as usual, with extra-linguistic evidence. ${ }^{79}$

The origin of this question lies in Greek grammar: although the Greek infinitive is of a completely different morphological and syntactic nature than the Arabic masdar, the connection between them becomes obvious when we compare the names given to the Greek infinitive and the Arabic masdar. The current name for the masdar, ism al-fil (verbal noun) corresponds to the Greek ónoma tou rhema${ }_{10 s}{ }^{80}$ When Zağğāăg $\overline{1}$ tells us that the masdar is to be regarded as the name for the actions of the things represented by the nouns, ${ }^{81}$ he is actually translating the Greek ónoma tou prágmatos. ${ }^{82}$ There are also traces of Greek doctrines in the arguments which are adduced for or against the priority of the masdar.

The first argument for the priority of the masdar is the one implied by Sibawaihi's description of the verb, in the interpretation of later

${ }^{75} \mathrm{~K}$ üfan grammar used another term to denote the transitive verb, namely $n a \bar{q} i^{\circ}$ (fallıng) (cf. Weıl, 1913, 72, note 1)

${ }^{70}$ b Anb Ins 102,6-107, 24; cf Asr 69, $22-71,19$

${ }^{77}$ b Yaīi, 135, 11-136, 13, Suy Ašbāh, 1,61 sqq, Iqt 180-1, according to Mubārak, editıon of the Idāh, p 56, note 1, Sirāfi deals with this question in the commentary on the Kıtäb, 1,9

${ }_{78}$ Ibn Ganāh, Opuscules, pp 12-3; Kımhı, Mıkhlol, ed. Chomsky, pp 363-4, cf ib note 633 for a general discussion about the theories on this point in Hebrew grammar

${ }^{79} \mathrm{Cr}$ below, chapter VII, for logical arguments used in the discussion concerning the priorily of the masdar.

${ }^{80}$ E.g. scholıa D T 400, 25: Apoll Dysk. frg. 87 sqq.

81 Zağğ Iḍ 56, 3-8

82 E.g. scholia D.T. 72, 24; 399, 34, 558, 22; Choirob 2, 7, 12. 
authors: 'As for the verbs, they are patterns taken from the expression of the events of the nouns'. ${ }^{83}$ The actions of the nouns, according to this interpretation, are the masdars, and the verbal forms are taken from the masdars. 'Taken from' ( $m a^{\prime} h \bar{u} \underline{u}$ ) receives the meaning of 'etymologically derived from', and this is the usual interpretation given to it by Western scholars as well. As regards the idea of an etymological relation between verbs and infinitives, we may refer to an observation made by Apollonios Dyskolos: 'From the infinitive itself stem all conjugated forms, and within the infinitive they are absorbed again'. ${ }^{84}$ This Greek grammatical theory, which makes the infinitive the root of all verbal forms, is borrowed by Fārābì in his description of the Greek kanónes onomatikoi kaì rhèmatikoi: ${ }^{85}$ '(The rules distinguish) between those forms which are mașadir - those are the forms from which the verbs are derived-, and those forms which are not mașādir; (they also show) how the mașädir are changed into verbs'.

The Bașrians deduce from Sibawaihi's words that the masdar occupies a higher position in the hierarchical system of the Arabic language, and they assert that the infinitive is primary with regard to the verb. Another way of saying this is to state that the masdar is the genus ( $\check{g}$ ins) of the verbal forms. In Arabic terminology this means that an action, be it a single or a repeated one, can always be described by the masdar. We find the same statement in Greek grammar. ${ }^{86}$ Additional arguments mentioned by the Bașrians are:

1. the masdar is the noun of the verb (ism al-fil); nouns are prior to verbs; therefore, the masdar is prior to the verb. ${ }^{87}$

${ }^{83}$ Sib Kit. 1, 2, 2-3; cf above, chapter III A

${ }^{84}$ Apoll. Dysk frg. p $90=$ Cholrob 2, 209, 13-4 [G 32]; Greek grammar does nol, however, grant the infinitive the first place in the hierarchy of the verbal forms, of the sentence preceding this quotation. 'You must know that the infinitive occupies the second place, and rightly, even though it should have occupied the first place, being the principle and, as it were, the root of the verbs, for from the infinitive ...' Apollonios' opınion was not very consistent, of below.

B Far. Ihs 14, 5-7 [A 45]: on this passage, cf. above, chapter III B. The use of the word masdar in this Greek context suggests a Greek orıgin for this word (?).

86 b. Gin Has. I, 25, 5-6; 2, 206, 8 sqq ; c「 1, 27, 2 sqq. with Apoll Dysk. synt. 325, 1 sqq (quoted below, cf. note 103).

87 b. Anb. lns 103, 12-6 (masdars are nouns; therefore, they can stand on their own, and do not need a verb: this means that they are more than the verbs. a verb cannot stand on its own, but needs a noun), cf. scholia D.T. 558, 21-8. Contrast with this the reasonıng of Choiroboskos, 2, 210, 6-12: an infinitive and a verb can form a sentence together (e.g. hairoumal phlosophein, I prefer to meditate); this shows that infinitives cannot be verbs, but must be adverbs An objection against Ibn al-Anbārīs argument, cf. below, chapter VII, note 30 . 
2. the name masdar shows that the masdar is the origin (masdar) of the verb. ${ }^{88}$

3. not to every masdar does a verb belong; this proves that the masdar is prior to the verb (this morphological argument was used by Zağğăğ, Zağğāğì's teacher). ${ }^{89}$

4. the form of the masdars vary; therefore, they are prior (a morphological argument attributed to Ibn as-Sarrāä). ${ }^{90}$

5. the meaning of the masdar is always found in the verb, while the opposite is not true (an argument adduced by the ahl an-nazar, i.e., the logico-grammarians). ${ }^{91}$

Two other arguments are mentioned by Ibn al-Anbārī:

6. the masdar signifies an absolute time (zamān mu!laq), the verb a special time (zamān muiayyan). ${ }^{92}$

7. the masdar signifies a pure action, the verb an action together with the time of that action. ${ }^{93}$

Just as in Greek grammar another theory is put forward, namely that the infinitive is nothing more than a derivative form of the verb, actually a sort of adverb, ${ }^{94} \mathrm{Ku}$ fan grammarians held that the verb is the principle $(a s l)$ from which the rest of the verbal forms are derived, including the masdar. The Küfans propose the following arguments for their point of view :

1. the masdar is only a reinforcement of the meaning of the verb (taukid), e.g., in the expression daraba zaid darban (Zaid hit really hard) (this argument was used by Abū Bakr ibn al-Anbāri) ${ }^{95}$

88 Suy Iqt. 80-1, Zağğ. I̦̣ 58, 14-8.

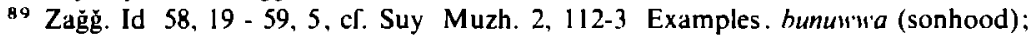
umūma (motherhood)

90 Zağg Iḍ 59, 6-12

91 Zağg Id. $59,13-60,2$, the same argument in the discussion concerning the priority of the noun, cf. below, chapter VII, note 99 .

92 b Anb. Ins. 103, 5-12

${ }^{93}$ b. Anb Ins 103, 16-19. These last two arguments are only variants of Zağga āḡìs fifth argument (also mentıoned by ibn al-Anbāri, Ins. 103, 22 sqq), namely that the masdar expresses less meaning than the verb, in other words, that the masdar has less accidents than the verbs Were the masdar derived from the verb it would have an added meaning, such as, for instance, the particıples have This idea is explained by means of a comparison with a metal and the objects made from it, cf below, chapter VII, note 25 .

94 Apoll Dysk frg. p 87 sqq.

95 Zağğ Iḍ. 60 ult. - 61, 6. 
2. the name masdar shows that the verb is the principle, and that the masdar is derived from the verb, contrary to what is asserted by the Bașrians. ${ }^{96}$

3. the masdars are formed according to the same phonetic rules as the verbs, i.e., if the verb has a strong radical, the masdar has likewise a strong radical, and if the verb has a weak radical, so does the masdar. ${ }^{97}$

Three more arguments are mentioned by Ibn al-Anbārī:

4. syntactically verbs may prevail over the masdars, i.e., they may have a masdar as their object; therefore, they are prior to them. ${ }^{98}$

5. a masdar presupposes the action of an agent, which is expressed by the verb; therefore, the verb is prior to the masdar. ${ }^{99}$

6. not to every verb does a masdar belong; this proves that the verb is prior to the masdar (contrast this with the third argument of the Bașrians!). ${ }^{100}$

Some Greek grammarians did not consider the infinitive a real verb, because of the fact that it is devoid of the characteristics of a normal verb, such as person, number, verbal mood, while it has some

96 Zağğ. Id 61 ult $-63,10$ This argument is a common trick in this sort of discussion, namely that you reverse the meaning of a term in order to obtain from it an argument in favour of your own theory. We can compare the procedure in the discussion about the masdar with the discussion about the hurūf al-íräh in the third problem of Ibn al-Anbārì's $I n \subseteq ̣ a f$, where the Küfans play the same trick with the term harf al-iräh (b. Anb. Ins. 13, 15-7). We find it also in theological debates: both partues in the discussion about free will used the term 'Qadarite' for their adversary, cf. Aš'arí, Ibāna, 47, 7 sqq., Watt, 1971, 28-9; van Ess, 1965, 128-30

97 Zağğ Id. 60, 3-9. On the other hand. there is the Basrian argument that masdars somelımes have other consonants than the verbs When al-Asma'i says. 'Often the masdar is derived from another form than the verb' (rubbamä 'šlıqqa 'l-mașdar min gair lafz $a(-f i l)$ (Zağg. Mağ 140, 1-2) he is in fact undermining his own Kūfan theory, because it is precisely the uniformity of verb and masdar which is used as an argument for the priority of the verb. A practical example of this question is found in Rummāni's commentary on Sïbawaihi's Kıläb (ap. Mubārak, 1963, 311) 'The pattern if älaltu from the word huw'wa (dark red or green colour) is ıhwäwailu ... and the masdar from it is $i h w y \bar{a}$ ' Some grammarians say that it is better to say ihwaiw'ä", because the " $y$ " is the result of the change of the added alif in ihwawaitu, just as it is changed in suwair But Sibawaihi does not mention this. The difference between the two forms is that in the masdar we have the original form, without any change, because the verb is derived from the masdar ${ }^{\circ}$ [A 46].

98 b Anb lnș 102, 12-5

99 b. Anb. Ins 102, 21-3

100 b. Anb Inș. 102, 18-21 (namely in the case of such expressions as nima, bi'sa, $m a \bar{a}$ afala, which are verbs according to the Bașrian theory, of problems 14 and 15 , Ins. pp. 47-68). 
of the characteristics of the noun ${ }^{101}$ This is the reason why the infinitive is called aparémphatos, $1 \mathrm{e}$, a form which only signifies the pure meaning, none of the accidents The argument proposed against this opinion is that the infinitive is the real verb, which signifies only and exclusively the action in itself with no accidents attached to it ${ }^{102}$ In the words of Apollonios Dyskolos 'As we have said before, the mood of the infinitive is the most general mood, which of necessity lacks those things we have discussed before, namely person and the accident number These are not connected originally with the verb, but only serve as an attribute of the persons who partake in the action For the action in itself is one, e g writing, walkıng, after it has been connected with persons, forms lıke "I walk, we walk" are derived from $1 t^{\prime}{ }^{103}$

Some people are not convinced by this conception of the infinitive as the general mood, and they continue to regard the infinitive as somethıng derived from the verb, as a sort of adverb ${ }^{104}$ These people wish to exclude the infinitive from the verbal system because of the fact that it does not have any of the characteristics of the verb, just as the participle, which is devoid of all those characteristics, is excluded from the verbal system' ${ }^{105}$ In that case, the infinitive cannot remain the 'root' (rhiza) of the verbal forms, stıll, most grammarians believe it to be just that Even more difficulties arıse when we continue to regard the infinitive as a verb, while at the same time we call tt the noun of the action (ónoma tồ prágmatos), or when we call the infinitives the 'nominal categories of the actions' (onomatıkai katègoriat tôn pragmátôn)-Apollonıs Dyskolos manages to make these two statements in one and the same passage ${ }^{106}$

${ }^{101}$ Eg Choirob 2, 6, 8 sqq, Sophr 2, 411, 11

102 In other words, infinitıves denote prágma without ousia, scholıa D T 400, 9-11

103 Apoll Dysk 324, 10 - 325, 3 [G33], cf Choirob 2, 7, 12-5

104 Their arguments are mentioned by Apoll Dysk synt 320-2 and by Chorrob 2 , 210,13 sqq The arguments against their theory, Apoll Dysk synt 323-4

${ }^{105}$ Apoll Dysk synt 320,6 - 321, 2 [G34] Translation of the entire passage 'An attribute par excellence of the verbs is mental condition, but this is incompatible with the infinitives, together with the categories of number and person, which cannot be expressed by the infinitive, just as the participle , which is devoid of all these characteristics, is excluded from the verbal system' In Arabic grammar the participle is excluded from the verbal system, because it has something more than the verb, namely the added meaning of a noun

106 Apoll Dysk adv 129, 20-1, of also scholia D T 400, 5-9 Rhiza is used by Sophr 2, 411, 2-7, in the same sense arche (ib), and hule (1b 410,36) 
If we accept the infinitive as part of the verbal system, the problem of its position within that system remains: some Greek grammarians gave the infinitive the first place, because it is the root of the verbal forms: 'Some people wanted to put the infinitive in the first place, reasoning that it is, as it were, the raw material and the origin of the verb. This is the reason why it has not added to its signification "subjectivity" (i.e., the verbal moods), or the persons, or the numbers: for original elements are always simple, just as the four elements as against the bodies (which consist of them), and the twenty-four elements (sc. the letters of the alphabet) as against the words, and shapeless clay as against the household goods made from it' ${ }^{107}$ As a counterargument, the fact is mentioned that the indicative mood is the 'stem' of the verb, from which the other forms are derived. ${ }^{108}$ Moreover, the acting person comes before his actions, and the verbal form which expresses the combination of the acting person with his action must needs be prior to the pure action, expressed by the infinitive. ${ }^{109}$ Apollonios Dyskolos himself changed his mind about this point: having first placed the infinitive after the indicative, he later put it at the beginning of the verbal system.

In conclusion we can say that in all these discussions the fact is emphasized that the infinitive signifies the pure action without further accidents. ${ }^{110}$ This justifies our considering it the 'general verb' (genikon rhèma). ${ }^{111}$ Herein lies the resemblance between the Greek and the Arabic data: the contradiction between on the one hand the verbal nature of the infinitive, and on the other hand its nominal characteristics. In both grammars this resulted in the same appellations, and in a communis opinio to the effect that the infinitive and the masdar are the rhiza and the așl of the verbal forms; in both grammars, too, the opposition against this point of view was not strong enough to make people abandon it. Close parallels in morphological arguments were not to be expected because of the great difference in nature between the Greek infinitive and the Arabic masdar. But the fact that both

\footnotetext{
107 Sophr. 2, 410, 36-411, 2 [G 35] For the comparison, cf. above, note 93

108 Sophr. 2, 410, 34.
}

109 Scholı D T 400, 5-9, cf above, note 99 At this point the discussion in the Idāh takes another turn (Id. 56 ult. - 57, 3) Zağgàgei tries to show from the priority of the acting person in other circumstances the priority of the nouns over the verbs

110 In Greek, of course. the infinitive retains the accident 'tense'

11 Apoll Dysk. synt 325, 12 - 326, 2, scholia D T. 546 (explanation of the notion gemikon onoma) With regard to the genkin rhèma, cf. Ibn Hazm's concept of an 'expression verbale commune aux choses', Arnaldez, 1956, 139-40. 
groups of grammarians used the same appellations, and arrived at the same conclusions is sufficient proof that in this point, too, Arabic grammar underwent the influence of Greek grammar. In other words, Greek grammar provided the raw materials, the rest of the building was set up independently by the Arabic linguists, as in so many other cases. 
'Apart from the doctors, there is nothing more ridiculous than a grammarian'.'

The system of Arabic grammar is held together by a rigid complex of methodological rules or norms, the so-called 'principles of grammar' (ușül an-naḥw). Similar principles are also followed in other branches of science, such as theology, jurisprudence, tradition, and exegesis of the Qur'ān, and they are generally believed by Arabic scholars to belong to one and the same system. Their use in these sciences illustrates how the development of Islamic culture depended on the regulating system of working principles, and how different sciences influenced each other through the principles and the interpretation of the various elements of the system. In the law the system of principles was used from the beginning of the 'Abbāsid caliphate: aš-Sāfi'i (d. 820/205) was the first to bring the different elements together into a consistent whole, after various scholars before him had already used them in their own conception of the law. ${ }^{2}$ In Arabic grammar this system already existed at the time of Sibawaihi and al-Halil. ${ }^{3}$ In this chapter we shall try to prove the thesis that these principles are connected with those that were used in Greek empiricist medicine. In antiquity they already served as a model for a new way of comparing facts of speech in the so-called Kanónes hellenismou ${ }^{4}$ We shall first give an outline of the epistemological theory implied by this trend in medical practice. After that, we will try to show how Greek grammar borrowed its criteria from this system, and how, under its influence, a system of judging the facts of language was developed that runs parallel to the Arabic uṣül an-naḥw.

\footnotetext{
I Athenaios, Deipnosophisiae, XV, p. 666 a [G 36].

2 Schacht, 1953; on the development of juridıcal termınology Ansārī, 1972 (ığmä๋ 282 sqq ; qlyàs. 288 sqq.).

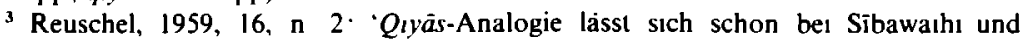
Halī in einer erweiterten Bedeutung nachweisen. For the use of quās in early Arabıc grammar. Mubārak, 1974³, 51-71: Daıl, 1968, 46 sqq (al-Halīl): 80 sqq. (Sibawaıhı).

4 Cr above, chapter III B
} 
Fundamental to the study of empiricist medicine is Deichgräber's Die griechische Empirikerschule, ${ }^{5}$ a collection of fragments with an excellent introduction about the theoretical background of the empiricist theories, in which the author explains how and why empiricist physicians differed from - and emphatically wished to differ fromcurrent rational and dogmatic theorizing. This difference manifested itself most clearly in the specific opinion about the value of an analogical judgment: we find here the same reluctance to accept a rational principle as an explanation of physical events as we find in early Islamic theology-though, of course, for other reasons. The empiricist school-which cannot be called a 'school' in the strictest sense of the word, but which was only a way of practising sciencewas 'founded' about 250 B.C. by the Greek physician Philinos of Kos, who dissociated himself from the dogmatic schools of his time. Many other physicians, most of them working in Alexandria, the centre of the empiricist school, began to practise according to his principles; the best known among them were Herakleides of Tarente (1st half of the Ist century B.C.) and Theodas of Laodikeia (about 100 B.C.). The most famous of them all was Sextus Empiricus (about 150 A.D.) who dedicated his life to a complete refutation of everything dogmatic, whether with respect to medicine, philosophy, or grammar. After him the 'school' disappeared, only to leave traces in many quotations by writers such as Celsus and Galenos.

The basic thesis of all these physicians was that knowledge can only be derived from perception by the senses, to which all other criteria of knowledge are reduced. Their dialectic methods are mostly based on common Skeptic arguments, such as the equivalence of all theories, the incompatibility of scholarly disagreement with the claim of scientific rationality, the reductio ad absurdum, the regressus ad infinitum, and the uselessness of all theories. ${ }^{6}$ The most important working

5 Pauly/Wissowa, RE V, 2, 2516-2523 s v Empırische Schule (Wellmann), Deichgräber, 1930, also Edelstein, 1933.

${ }^{6}$ For the rich history these arguments had in Islam van Ess, 1970, 45-6; cf the example mentioned in chapter VI, note 47 , also the discussion about the question how It is possible that scholars disagree about scientific questions (a well known Skeptic argument, Stough, 1969, 102; cf Tauh Muq p 233; Zağğ. Id. 46-7. A common Skeptic argument against the art of grammar is that it is superfluous, because either its rules are in accordance with current speech - in which case we do not need grammar , or its rules are contrary to current speech-in which case it is the wrong sort of grammar, cf. Sext. Emp. adv math 1, 184 sqq ; 200 (Varro, De L L 8, 27, 33); Celsus prooem c. 27 sqq ap. Deichgràber, 1930, 93, 9-14, Fārābī, Ihsā', p 30, cf Mahdı, 1970, 76. On empiricism and skepticism 'Stough, 1969, I1-4; 107-25 
principle was observation, which a scholar can do himself (autopsia, empetria). But they define 'science' (téchnè) as 'a collection of observations', ${ }^{7}$ and as nobody is able to collect in his experience the whole gamma of physical events, a scholar is also dependent on the results of former experiments and observations (historia) ${ }^{8}$ It is required that the informant through whom these results reach him should receive his own knowledge from physical observation, that he is free from prejudice, and reliable and expert. The safest conclusions can be drawn from historical material, if the tradition is unanimous (sumphônia). ${ }^{9}$ If all these principles together fail in explaining the phenomena, there is a last resort: the observation that the same circumstances often result in the same healing process; this observation may be used as a working principle. The greater the similarity of the carcumstances, the greater the probability of success, and this principle of 'basing one's conclusions on similarity' (metábasis tou homoiou) is therefore a principle of a probabilistic nature, which cannot give certain guarantees. We must also emphasize that a conclusion on the basis of this principle does not proceed from a compelling and certain, intrinsic cause by virtue of which events are similar. In this respect empirical analogy differs from dogmatic analogy: an empiricist physician is not interested in the question whether 'something causes something else to happen, because that something else is similar to it'; for him it is enough to know that 'similar events (generally) happen in this or that way'. The metábasis tôn homoiou is 'a way to find a solution', ${ }^{10}$ 'an instrument to find resources'; ${ }^{11}$ in modern terms, it is a heuristic strategy which serves to fill the gap in our incomplete empirical knowledge. Finally, empiricist medicine used a principle known as the diastole, which consisted in 'separating the particular from the general'. ${ }^{2}$

'Thus, Latin speech consists of nature, analogy, custom, authority. The nature of nouns and verbs is invariable and passes only on to us

7 Deichgraber, 1930, 95, 15 (hathroısma tôn theôrèmátôn), ef lb p 297. 'Die empirische Wissenschaft ist eine Summe wiederholter Beobachtungen, kein systematisch geordnetes Ganze wie die Stoische' For 'Stoische' one may also read 'dogmatische'

B Defined as 'Communication of what has been seen', ib 65, 32 (apangelía tón ophthéntôn)

I Ib $67,19,128,20$

${ }^{10}$ Ib 95, 30 (hodos epi tèn heúresin) On the Skeptıc background of this doctrıne Stough, 1969, 133-7

11 Deıchgraber, 1930, 95, 23 (órganon boèthèmátôn heuretıkón)

12 Ib 154, 8-11 (apó toû koınoû tò idıon apokrinem) 
what it received, nothing more and nothing less ... Analogy is an arrangement of speech as it is handed down by nature; it distinguishes uncouth from cultivated speech in the same way as silver is distinguished from lead... Custom is on a par with analogy, not by virtue of its technique, but by its force; it is only accepted because it is supported by the agreement of many people ... Authority ... does not contain reason, nor nature, nor custom: it is only accepted on account of the opinion of orators'. ${ }^{13}$ In this way Charisius describes the nature of speech by means of the four criteria natura, analogia, consuetudo, auctoritas. These four criteria of correct speech may also be found in a somewhat different arrangement in Quintilianus' writings. ${ }^{14}$ Barwick ${ }^{15}$ and Fehling ${ }^{16}$ have extensively investigated the various accounts of this doctrine and established their mutual dependency, as well as the fact that the doctrine of the criteria has a Greek origin. They are related with the Greek kanones orthographias: etumologia, analogia, diálektos, historia. ${ }^{17}$ Nowadays, it is generally accepted that the model for this system may be found in the methods which empiricist physicians used to derive knowledge about physical facts from observation by sense perception. ${ }^{18}$ Grammar was not the only science to be influenced by empiricist theory: the science of law also borrowed many elements from the empiricist system of criteria. ${ }^{19}$

13 Constal ergo Latınus sermo natura analogla consuetudine auctoritate. Natura verborum nominumque immutabılis est nec quicquam aut plus aut minus tradidit nobis quam quod accepit Analogia sermonis a natura proditı ordinatio est neque aliter barbaram linguam ab erudita quam argentum a plumbo dissociat Consueludo non arte analogiae sed viribus par est, ideo solum recepta, quod multorum consensione convaluit, . Auctoritas . . non ... quicquam aut rationis aut naturae aut consuetudmis habet, tantum opmione oratorum recepta est, Char. art gram $62,14-63,7$, probably quotıng from Varro.

14 Sermo constat ratrone velustate auctoritate consuetudime. Rationem praesfal prae(ipue analogıa, nonnumquam ef etymologia' 'Speech consists of rationality, tradition, authority, custom. Rationality is mostly represented by analogy, sometimes by etymology' (Quint inst. orat 1, 6, 1 sqq.) On Quintılianus' criteria of correct speech: von Frıtz, 1949

15 Barwick, 1922, 213-5 et passim.

16 Fehlıng, 1956/7.

17 Barwick, 1922, 214.

18 Fehling, 1956, 263-4. On the observatio = paratèresss. Melle, 1952; I have not been able to use Siebenborn, 1976.

19 We will not go into this complicated matter, but only refer to the rhetorical treatise $A d$ Herennum (ed and transl. H. Caplan, Cambridge, Mass. 1964), chapter XIV, where it is stated that law consists of the following elements: nature (natura), statute (lex), custom (consuetudo), precedents (iudicalum), equity (aequum el bonum), agreement (pactum); in oratorical practice, the categories constıtuted a useful means for presenting arguments, e.g. (in a somewhat modified form), Cic. Pro Milone, cap. 33 (ratıo, necessilas, mos, natura). 
Not surprisingly the empiricist idea of science as a collection of the most frequent physical facts, as an empeiria, is found in grammatical literature: Dionysios Thrax defined grammar as 'practical knowledge of the words that occur most frequently in poets and writers of prose'. ${ }^{20}$ Our conclusion is that grammarians, influenced by the empiricist doctrine, used to solve linguistic problems and to establish correct speech as against barbarisms and solecisms by means of the four criteria of correct knowledge, i.e. in the case of grammar: the nature of speech; the analogical comparison of linguistic forms; the normal, daily usage; and the authority of writers in the past. The relative importance of each of these criteria may differ when compared with the criteria of medicine, but this is only to be expected, in view of the essential difference between the two disciplines.

The Arabic system of the $u s \bar{u} l$, as we shall describe below, shows a striking similarity to the Greek criteria. We could, of course, attribute this similarity, in so far as it concerns the linguistic $u s \underline{u} l$, to a direct contact of Arabic grammarians with living Greek grammar, but in that case the existence of the system in other sciences remains unexplained, unless we are to place grammar at the basis of the rest of the Islamic sciences. It seems much more plausible to seek the origin of the system as it existed in the Arabic world, in the translations of Greek medical works, especially those of Galenos (d. 199 A.D.), who was a prolific writer in this field, and who also wrote about the methodology of his profession, i.e. about the various theories concerning the methods a scholar should use to attain knowledge about medical and physical matters. We know that those of Galenos' works that specifically discuss empiricist medicine were translated, or at least known in the Arabic world, from Hunain's list in his Dikr mā turği-

20 Dion. Thr. 5, 2-3 [G37], cf. Sext. Emp. adv math 1, 57; 76 The epi to polí

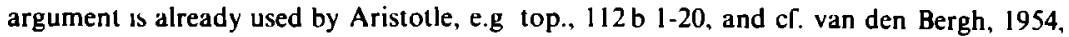
2, notes 1.6, 2.1. Dionysios Thrax considered grammar an emperria notwithstanding the modern custom to refer to his book as the Téchnè of Dionysios Thrax-, cf Barwick, 1922,217 , n. 2. For the discussions concerning the nature of grammar: ib. 221 sqq. Arabic grammarians preferred to follow the Slotc custom and called grammar a technique ( $\left.\sin \bar{a}^{\prime} a\right)$, e.g. Hwār Maf. 42, 13; b Hald Muq 546, 23; b Mađ̣ā', Radd, 88, $12 ; 93,11$; cf Rummāni’s definitıon of grammar: 'The art ( $\operatorname{sinā} a)$ of grammar is based on distingusshing correct [rom incorrect speech, in accordance with the opinions of the Arabs, by a sound analogy' [A 47]. (Mubārak, 1963, 247; ıb 277, 8 ahl as-sinära = the grammarians). Ibn Ginni distınguishes between san'a, i e, the phonetic aspect of language, and lugia, i.e. the morphological-lexıcal aspect of language (Has. 1, 356, 2 et al ; sinä'i vs. ma'nawi, ib. 2, 156, 13). 
ma min kutub Ğàlinūss, ${ }^{21}$ particularly Galenos' work Kitāb fí 't-tağribat at-tibbiyya (Book on medical experience), which has been edited by Walzer. ${ }^{22}$ It is a well-known fact that medical writings were among the lirst to be translated, and that the tradition of the medical philosophers from Alexandria, the centre of the empiricist 'school', continued to exist during the Abbāsid caliphate. ${ }^{23}$ The early translators were generally practising physicians as well as philosophers who heeded Galenos' injunction that a good physician should also be a philosopher. ${ }^{24}$ Many of these medical books were already known long before the times of Hunain, not only in Syriac translations, but also in Arabic. ${ }^{25}$ The first known translator, Yahyā ibn al-Bițriqu, a Byzantine Roman who lived in the reign of the caliph al-Manșūr (754/137-775/159), translated Ptolemaios' Tetrabiblos and other, medical treatises. ${ }^{26}$ That in this process empiricist works and methods were very popular is proved among other things by Mas üdi's remark that in the reign of al-Wâtiq (842/227-847/232) there were still empiricists practising at the caliphal court. ${ }^{27}$ It was through these translations and maybe through contact with the first translators that Arabic

21 Hunain, Dikr, 46, 3-13: 'As for the books in which he follows the methods of the empiricists, I have found three treatises about them His book on medical experience This book consists of one treatise, in which he sets forth one by one the arguments of the followers of experience and of the followers of analogy (sc the dogmatists). I translated it not long ago into Syriac for Buhtišŭ $\bar{u}^{*}$... To these works also belongs his book on the stimulation of the study of medicine This book consists likewise of one treatise. In this book he gives a paraphrase of the book of Menodotos, it is a good, useful, and spiritual book. I have translated it into Syrıac for Gibrill. Hubaiš translated it into Arabıc for Ahmad ibn Mūsā ... To these works also belongs his book on the fundamentals of experience This book also consists of one treatise. I have a manuscript of it among my books; I did not translate it' [A 48]. On these books' Steinschneider, $1960^{2}, 351$, no. 85 , 345, no. 61; 351, no. 85. For Hunain's medical background and activitues: Meyerhof, 1926, Brockelmann, GAL, I, 224; S I, 366.

22 The Arabic translation of the first of Galenos' books mentioned by Hunain (On medical experience, Peri tès theatrikès emperrias) has been edited by Walzer, 1944 , cf. Steınschneider, $1960^{2}, 351$, no. 85. On Galenos: Temkin, 1973; Kieffer, 1964, esp. $1-18$ (this is the Eisagóge dialektikè translated by Hubais, of. Steınschneider, 1960². 348, no. 70, Hunain, Dikr. 51, 10-3).

23 Meyerhof, 1930.

24 Galenos' book Hótı ho árıstos ıatròs kai phılósophos in the Arabic translation of 'Isā ibn Yahyā has been edıted by P. Bachmann, Götungen, 1965 (also translated by Hunain, Steinschneider $1960^{2}$, 345, no. 59; Hunain, Dikr. 44, 15-9). On Galenos' philosophical writıngs in Arabıc translation: Steinschneider, 1960², 346-8; Badawı, 1968, 112-3; Walzer, 19632, 142 , + note 1; Amine, 1959, 86-91.

25 Hitti, 19689, 311 sqq.

26 Brockelmann, GAL, 1, 221-2; S 1, 364; Steınschneider, 1960², 58, 200, 313, 316-7, cf. p. 257 s.v.; Dunlop, 1959; Badawi, 1968, 190

27 Mas'ūdi, Murūğ, 7, 173; cf. van Ess, 1970, 35, n. 73; 24, n. 14. 
science in its early stages became acquainted with the highly developed methodology used by the empirical physicians, as presented to them by Galenos' writings. This system served as a scientific foundation not only for those scholars who practised medicine, but also for those who studied law or discussed theological problems, and even for those who tried to describe the Arabic language, like al-Halil and Sibawaihi. They used the same type of primitive analogy so characteristic of empiricist medicine, and checked it against the very same elements of experience (c.q. the Qur'ān and older poetry) and observation (c.q. the actual state of the language) that were commonly used in Greek medicine. It is clear that Sibawaihi could never have derived such knowledge from the Corpus Aristotelicum-which had not yet been translated at the time-, but only from a direct contact with those who understood Greek culture, in this case probably the early translators. The connection is shown not so much by the fact that these elements existed in both Greek and Arabic culture (although it is an important argument in itself), but rather by the fact that these elements were handled in the same way.

We have solid proof of the existence of the empirical criteria in Arabic medicine in the writings of the Christian physician Yūhannā ibn Māsawaih (d. 857/243), teacher of Hunain ibn Isḥāq and first vice-chancellor of the Bait al-hikma in Baghdad. ${ }^{28} \mathrm{He}$ says in his Nawädir a!-tibbiyya: 'Everything that is agreed upon by the physicians, which is attested to by analogy, and confirmed by experiments, let that be your basis (sc. of knowledge in medical matters)' ${ }^{29}$ Here we find the medical criteria iğmār (= sumphônia), qiyās (= metábasis tồ homoiou), and tagriba (the experiment which is indispensable for the autopsia). Not only did Yūhannā ibn Māsawaih write about these matters, but we have also a report about a discussion that took place at the court of the caliph between Ibn Māsawaih and his teacher, Gibril ibn Buhtī̌š̆ (d. $\pm 830 / 215)$; $^{30}$ according to some people, Hunain ibn Ishāq was also present. The caliph asked them: 'I would like to know the essence of obtaining medical knowledge, and the basis of its principles: is it by the senses (hiss), or by analogy (qiyās), or by tradition (sunna); are these things (sc. this knowledge) obtained by rational principles, or is knowledge of these things and the method

28 On Yuhannā ıbn Māsawaıh Brockelmann, GAL I, 266, S 1, 416. Meyerhof, 1926, 717. Meyerhof, 1930, 402.

${ }^{24}$ Yuh b Mas. Nawādir, 33, 9-10 (= fasl. 132) [A 49]

${ }^{30}$ For the Buhtišū' famıly. Peters, 1968, 44, 59 
(of arriving at this knowledge) obtained according to you by hearsay.... ${ }^{31}$ According to some of those present, physicians derive their knowledge from four principles: natural (tabi $\vec{i}$ ), accidental ("aradi), rational (irädi), and analogical (naqil ${ }^{32}$ ) principles. This is the method of those (Greek) physicians who base themselves on the empeiria (tagriba). This text is a very important one, since it provides us with evidence about the use of terms from the field of the ușul in discussions about medicine at an early date ( 1 st half of the 9 th $/ 3$ rd century). Especially interesting is the term sunna, which is better known as a term used in the sciences of law and tradition. ${ }^{33}$

This originally medical system was, of course, used in different ways in each discipline by which it was taken over. The criteria of grammar, law, and theology, for instance, are not identical, and they do not have the same power. Comparisons between the various sets of principles were already made by Arabic authors, for instance by Ibn Ginnī in his Hasă'is under the heading 'On the norms of the Arabic language, whether they are theological or juridical ones?' ${ }^{4}$ Ibn Ginni's conclusion is that grammatical norms are more related to theological norms, in so far as both are based on common sense, on reason, whereas juridical norms derive their power from revelation, which can only be accepted and believed, though not proved. On the other hand, grammatical norms are inferior to theological norms, because theology uses only norms which are based on necessary and stringent arguments, whereas grammar uses also another category of norms, namely those which are based on probable, i.e. facultative arguments. ${ }^{35}$ This is also stated by Zağğāğ $\overline{1}$ at the beginning of his chapter about the grammatical norms. ${ }^{36}$

As for grammatical arguments, they are described by Ibn al-Anbārī in his Luma al-adilla in the following way. Ibn al-Anbārì distinguishes between three different kinds of arguments (ușūl, adilla):

31 Mas Murūğ. 7. 173-80 [A 50]

32 Naqil might be termınologically related to metáhasıs toú homoiou

33 For the history of this term Ansar1, 1972, 259-82, sumna is also. though infrequently. used in grammar, e g Sib Kit. 1. 74. 7. cf. Carter. 1973. 147. also Suy Muzh $1,194,4$ (mm suman al-'arah)

${ }^{34}$ b. Gin Has 1, 48.96 the length of this chapter of the Hasä's shows the importance of the criteria for correct speech and the wish to be absolutely clear about their nature Loucel gives a paraphrase and a partial translation of this chapter, 1963 , $271-5(40-5)$

35 b Gin bb 1, 88, 1-3

36 Zağè. Id 64. 2-3. 
transmission (naql), analogy (qıyäs), and the argument called istișhäb $a l-h \bar{a} l$; the argument of $i g \bar{a}^{*}$ is related to the tradition.

Naql is the tradition concerning grammatical forms as handed down through earlier literature. Just as we saw above in the case of the historia in Greek medical writings, not every tradition is acceptable: the informant must meet certain requirements. Van den Bergh already recognized the similarity between the requirements in use in traditionist circles, and those of the Greek empiricists. ${ }^{37}$ It seems that grammatical practice was strongly influenced by the practice of the traditionists: in fact, the terminology that describes a tradition's usefulness and reliability is largely borrowed from that discipline. ${ }^{38}$

Unanimity ( $\left.i g m^{\prime} m \bar{a}^{2}\right)$ is one of the most frequently used criteria; it is considered obligatory for the correctness of a linguistic expression, and as such it is related to theological unanimity. ${ }^{39}$ It 15 used in all sorts of discussions not only in a general way, ${ }^{40}$ but also in the more restricted sense of 'unanimity of a certain group', just as theologians tended to restrict the notion of iğma $\bar{a}^{-}$to one single group of theologians, or at least to professional theologians, not to just anybody who cared to advance something about theology. ${ }^{41}$ In grammatical discussions we find for instance the unanimity of the grammarians, ${ }^{42}$ or the unanimity of the Küfans and the Bașrians. ${ }^{43}$ Schacht and van den Bergh discovered some connections between the ığmāe in Arabic theology and law, and certain procedures in Greek logic. ${ }^{44}$

The second, and far more controversial, norm is analogy (qlyās), which is defined by Ibn al-Anbāri as 'The interpretation of the meaning of the secondary in terms of (or: analogously with) the primary', ${ }^{45}$ and also as: "the comparison of the secondary with the

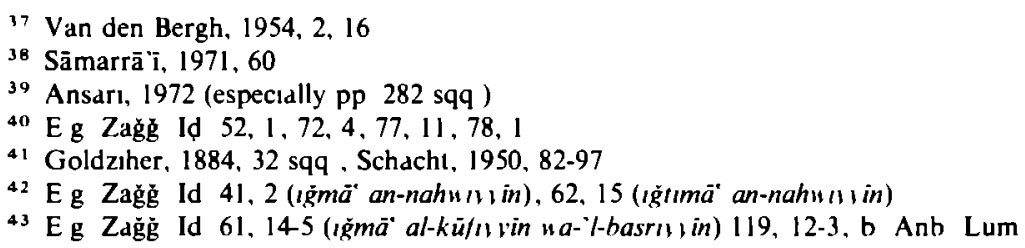
$44,9,47,2$ (both tımes with the addition 'unanimity is a deciding argument' ( $\mathrm{a} a-\%$ ' $\dot{g} m \bar{a}^{\circ}$ huğğa qätia)), cf also b Anb Ins 203, 12 (Basra), b Gin Has 2, 326, 14-7, and ib 1. 189 sqq (chapter on the use of the $\iota \dot{g} m \bar{a}$ as an argument)

$44 V_{d n}$ den Bergh deals with the probabilistic value of this argument, which is already used by Aristotle, 1954, 2, 198, note 3493 On Igmä in theology and its connections with the Stoic consensus ib 205, note 3623 On consensus as a trace of Greek logic in early Muslim legal science Schdcht. 1950, 83

45 b Anb Lum 42, 5-6 [A 51] 
primary by virtue of something that causes the secondary to be analogous to the primary'. 46

The admissibility of the qiyās has been an issue throughout the history of Islamic culture. One could even say that there is a remarkable correlation between a scholar's attitude towards analogy and his attitude towards Greek logic and science.

In order to understand why a criterion based on analogy could cause such tremendous differences of opinion, it is important to consider the history of Islamic science, and especially of theology. Early Islamic theology was confronted with a situation in which the conquered peoples were the possessors of a much superior science and culture, and also of a much greater experience in discussion and application of knowledge. On the other hand, the newly converted Arabs, Persians, and other nations, were urging their religious leaders to provide them with practical rules of life, and with arguments to defend themselves against the sarcasm of other religious communities. The theological experts were, therefore, forced to expand the limited number of Qur'ānic regulations, and, as their religious conscience did not permit them to invent such regulations on their own authority, they had to look for other authoritative sources of knowledge. Since not even the practice of the Prophet, as it was handed down by later generations, sufficed, nor the consensus of the (learned) community, they were compelled to use yet another method: reasoning by analogy. But here they were hampered by the fact that in these early times Islam could not at the same time hold the omnipotence of Allāh and the existence of causae secundae, which are inherent in and essential to the type of analogy used by Aristotle, and by Greek logic in general. Thus, another type of analogy arose, that of the qiyās in its early form: reasoning from one concrete instance to another, where the causes are only pseudo-causes, ${ }^{47}$ and where everything but a strict occasionalism is severely condemned. Every statement can only be proved by a preceding, similar, statement, until at last the ultimate proof is derived from Allāh, Who in His wisdom lets everything happen according to a customary pattern-although He could do otherwise, if He wanted to. Syllogistic reasoning was only taken over after the influx of translations of Greek philosophical writings. The introduction of these 'pernicious' foreign doctrines is often ascribed

46 Ib 42, 6-7 [A 52]

47 In orthodox theology the word sahah was used for these pseudo-causes, as against the "lal of the philosophers 
to the philosophers and the Mu'tazila, while it was said to have been introduced into orthodox theology by al-Guwaini the Imām al-Haramaini (d. 1085/478), the teacher of al-Gazzāli. ${ }^{48}$

There are two fundamentally different kinds of analogy: the qiyass $a \check{s}$-sibh and the qiyās al-illa. The qiyās aś-sibh-which does not fall under Ibn al-Anbārī's second definition-is based on a resemblance between the secondary and the primary. We might also say that this sort of analogy is an empirical principle consisting in the comparison between two things because they are alike in one or more respects. This is the original form of analogy as it was accepted by Muslim science at an early time - an analogy which has nothing to do with the classical Aristotelian syllogism. It is, therefore, not contradictory to the omnipotence of Allāh: it is nothing more than the establishment of a resemblance between two things which enables us to draw a conclusion about the secondary, based on the condition of the primary. We may draw this conclusion, since we suppose that Allāh created laws of nature, or rather that it pleases Him to let the same combinations of atoms happen regularly. There is nothing within the things themselves which could make them cause something else without the help of something outside them. Thus, nature and its phenomena bear witness to the omnipotence of Allāh, Who is the causa efficiens of everything. This philosophy is altogether different from the determinism we find in Greek philosophy; it is related more closely to the atomism of a Demokritos, ${ }^{49}$ in so far as there can be no causal basis for knowledge of natural phenomena; connections between phenomena bear an occasional character. What we have here described is the common view of Ašarism, and thus of orthodoxy. Some theologians, though, did not even accept an analogy based on mere resemblance: for Ibn Hazm even the establishing of a resemblance between two things is an unwarranted conclusion, not permitted by Allāh. ${ }^{50}$

The second sort of analogy is the later form, which came into use after the beginning of the activities of the Mu'tazila, who did accept

48 Brockelmann, GAL, I, 486-8, S I, 671-3.

49 This account is simplified in so far as we leave out the role that is attributed to the human agents in this process of causality, in partıcular the function of the kasb (that is the appropriation by man of his own acts which he is able to perform thanks to the fact that Allāh created in hım the accident of being an agent) in Ašarism; on this problem: Frank, 1966. In nature, causality is denıed by Aš'arì; for the resulting atomıstic philosophy: Anawatı, 1974, 99-102.

so Cf Arnaldez, 1956, 165-93. 
the independency of the accidental actions of the substances created by Allāh, and who could, therefore, also accept the notion of causality in nature. According to them causal analogy does exist, and it consists in the observation that two things have an inner 'cause' ('illa, ma'nā) ${ }^{51}$ in common that causes the secondary to be similar to the primary. This sort of qiyais has always been critized by orthodox theologians. ${ }^{52}$

The origin of the qiyäs is still a point of debate. Schacht and others have pointed to parallels in the Hellenistic world, especially to the resemblance between the qiyās and certain procedures in Roman juridical theory. ${ }^{53}$ We should not forget that the rhetorical schools all over the Roman-and later the Byzantine-empire taught the same juridical materials. This could explain the parallels between the first theoretical principles used in Arabic manuals of law, and those used by Roman lawyers in the rhetorical schools. There is another terminological parallel which might be mentioned in this context, namely between the qiyās and a principle used in Hebrew biblical exegesis. This principle, which is called hiqqis (literally: to hit one thing against another), ${ }^{54}$ is used for an extrapolation of the teachings of the Torah: it consists in the juxtaposition of two biblical regulations that share a common feature, and in drawing a conclusion from this. ${ }^{55}$ The procedure of hiqqišs reminds one indeed of the use of the qiyās in Săfi'ì's time, and a terminological connection between the two procedures is certainly not too far-fetched.

There remains the question of chronology. Supposing that at Sibawaihi's time there existed a more or less consistent system of criteria and analogical rules, we are left with the choice between the rhetorical schools with their juridical theories on the one hand, and the translations of medical works on the other hand, as possible sources for the Arabic system of $u s \underline{u} l$. It is true that the Arabs became acquainted

51 On "Illa and mainä, cf. chapter X, n 61, Nader, 1956, 86-7

52 For the attıtude of Muslim theologians towards analogy. Brunschvig, 1970;1971 We may refer to the empiricists' distunction between a qiväs analogismós (conclusion pointıng to invisıble beings $=q y \bar{a} s$ al- $/ l / a)$, which is to be rejected, and a quyás eptlogısmós (conclusion pointıng to visıble beings $=q u \bar{a} s$ aš-šibh), which is acceplable, both terms are used in the Arabic translation of Galenos' On medical experience, Walzer, $194458 \mathrm{sqq}$ They go back to Ainesidemos' theory of causal explanation: Stough, 1969, 97-9

${ }^{53}$ Schacht, 1950, 99-100, who quotes two articles by D. Daube in Law Quarterly Revien, 52, 265-6 and in Tulane Lan Review, 18, 365-6; cf chapter I, note 8.

54 Margoliouth compares the Hebrew term with the Greek verb sumbállein, Journal of the Royal Astatic Society, 1910, 320, quoted by Schacht, 1955, 99.

ss For the hiqqis: Zeitlın, 1964. 
early on with the educational tradition of the rhetorical schools, but we also know that medical writings were among the first to be translated, and that the first contacts with Greek science-especially in Alexandria-took place precisely in this field What is more, we have the testımony of Yūhannā ıbn Màsawaıh, quoted above, which proves that at least the physicians were aware of the existence of a system of criteria to judge the physical facts On the other hand, the study of grammar and grammatical norms was transmitted in the first place by the rhetorical schools In any case, both grammar and the sciences received their methodological principles from the empiricist system, and the same holds true for the study of law, so that even the transmission of the criteria through the rhetorical schools found its basis in medicine The Arabic system may have been even the result of an interaction between the various disciplines, which all shared the need to collect, to analyse, and to interpret an enormous number of facts These facts could be ordered according to some well defined principles, and these principles were borrowed from the classical tradition, possibly with the help of Hebrew biblical exegesis, in which these principles - or at least one of them-were already used before the beginning of Muslim science But at the basis of this system was the method of the empiricist school, which became known in the Orient through the translations of medical works, and possibly through direct contact, for instance in Alexandria

It goes without saying that, in the course of tıme, grammatical science took whatever elements it could use from other disciplınes (such as, for instance, the methods used by the traditionists for distınguishing between reliable and unreliable information) The sciences of tradition, exegesis, and law were so important in the daily life of the first centuries of Muslim culture, that they could easily exercise a considerable influence upon other sciences ${ }^{56}$ We have seen already that a grammatical informant must meet the same requirements as someone who transmits a tradition about the life of the Prophet Another example is that agreement between different sources is granted the same value and power in grammar as in law and theology 57

Perhaps the influence of other sciences applies also to the last of the three principles mentioned by Ibn al-Anbārì, the ıstıshāb al-häl, according to which one may draw a conclusion about the properties $79-93$

56 Kopf, 1956, cf above, chapter 1, note 61 (Carter's theory), Mubārak 1974³.

${ }^{57} \mathrm{Cf}$ above, notes 39,41 , discussion by Weiss, 1966, 62-8 
of something secondary from the properties of something primary. This is a particular kind of analogical reasoning, which, according to Schacht, ${ }^{58}$ is to be regarded as one of the traces of Greco-Roman law. On the other hand, one could suppose a connection with the empirical principle diastole, although the data are not very clear in this case.

In the law the use of the istishāb al-häl is better known than in grammar, although Ibn al-Anbārī dedicates a chapter of his book about the sorts of proof permitted in grammar to it. ${ }^{59}$ In the law the term is used for the legal assumption, in case of doubt or in the absence of solid proof, that the last known situation still obtains. According to Goldziher the use of this argument in legal discussions has its origin in the work of aš-Sāfíi (d. 820/205) or in the Sāfíite school. ${ }^{60}$ One good example is that given by Goldziher of a man who is missing, but whose death cannot be established with certainty. According to the istishäb al-häl this man must be assumed to be alive, and consequently his relatives may not inherit his possessions; the missing man himself may inherit from someone else, and in that case, the inheritance will be kept by the state. In the Hanafite school of law, the former decision is accepted, but not so the latter, since in this school istişăb al-hāl is only applied to the denial of a right, but not to the recognition of a right (li-'d-daf la $\left.l i-^{\prime} l-i \underline{t} b \bar{a} t\right){ }^{61}$ It goes without saying that for the Zāhirite lawyers, such as Ibn Hazm, the istișhäb $a l-h a \bar{l}$ is a favourite method. For Ibn Hazm it ranks as high as, and is part of, the consensus (iğmäa) of the community: if the community agrees about something, we dare not accept a change in that situation until we have solid proof (dalil) for the necessity of such a change. Such a proof can, of course, be only a text from the Qur'ān or a tradition from the prophet. ${ }^{62}$

In grammar this sort of argument is connected with the discussions about analogy (qiyās) and exceptions ( $\check{s} \bar{a} \underline{d} \underline{d}) .{ }^{63}$ Each word and

58 Schacht, 1950, 100.

s9 b. Anb. Lum. 86,5 sqq.

60 Goldziher, 1887; cf. Schacht, 1950, 126

61 Goldziher, 1887, pp. 235-6. Is there a connection with Roman legal praclice? According to Zlinszky, 1960, under Roman law a missing person was considered alıve untıl definite proof was given concerning his death; his capacity to accept an inheritance in absentio was the subject of many legal discussions (1b. 120-4).

62 b. Hazm, Ihk., 3, 385-90; 5, 590 sqq.

${ }^{63}$ Cf. e.g. ibn as-Sarrāğ ap. Suy. Muzh 1, 139, 5-13 and Suy. Iqt., 24-5. Zağğ Iḍ 72 pen. - 73, 3: the connection between this argument and the juridical theory of 
each category has its own rules, and we may only assume a change of these rules (c.q. an exception, in the case of a category of words), when we are able to point at a cause (illa) which is responsible for that change. In all other cases we must adhere to the primary rule (așl). ${ }^{64}$ The same may be stated positively: when we use the argument of an istıșhäb al-hāl we do not need any further proof, since the istișhäb $a l-h a \bar{a}$ suffices as a proof. ${ }^{65}$ A remainder of the discussion between the Hanafites and the Sāfi ites about the use of the istișăb in the case of the recognition of a right may be found in Ibn al-Anbārì's remarks about the argument $e$ silentio (al-istidläl bl-'adam ad-dalil) following on the discussion about the istișhāb al-häl: such an argument is rather weak, and can never be decisive in the case of an affirmation, at most in the case of a denial. ${ }^{66}$

By way of hypothesis we would like to point to the remarkable similarity of this argument to one of the norms of knowledge which was used in empiricist medicine: the diastolè or diorismós, defined in the Latin translation of Galenos' Subfiguratio Empirica in the following way: 'Something is a distinctio (diastole) if it distinguishes the particular from the general only by way of evident knowledge' ${ }^{67}$ and '.. the determination (determinatio $=$ distinctio) of somethıng, which they describe by saying that it is the property which distinguishes within a general category something which is particular in some respect'. ${ }^{68}$ In view of the fact that according to our theory all criteria of knowledge used by empiricist physicians are at the origin of the Arabic usül, we do not suppose that the similarity in this case is coincidental.

In Zağğăğì's system of grammatical norms the qiyāss ${ }^{69}$ (' $y a)$ provides the explanation of the linguistic facts which we have

exception (Istıınnā), ef Arnaldez, 1956, 156 for the Zāhırıte theory concernıng thıs doctrıne (every judgment from the Qur'ān or the tradition should be taken literally and generdlly, except in the case of textual evidence to the contrary) Apparently, Zdğgağg was rather fond of this principle of reasoning of Id $51,16-52,8,77,3-10,113,4-7$

${ }^{64} \mathrm{E} g$ b Anb Ins 172, 23-4, 261, 12, 303, 5, of Well, 1913, 9, 16, n 9

is $\mathrm{b}$ Anb Ins 199, 1

66 b Anb Lum 87, 10 sq9 (the discussion ib 88, 1 is in fact identical with the problem of Ins 199, 1-2 when there is an original form or rule, we do not need to bother about ddditional proof) The example ibn dl-Anbãri cites is the same as the argument Zağğăği uses in proving that there dre only three parts of speech, Id 43, 3-7 Cf also Id $129,12-3$

67 Gal ap Deichgraber, 1930, 59, 8-10 st solummodo distinguat proprium a commum per evidentes cogmitones, of $\mathrm{Gal}$ tb 154.8-11

th Ib 62.8 determmatio quam discribentes dicunt esse sermonem distinguentem a commumbus id quod est secundum unumquodque proprium

${ }^{69}$ Zağğ Id 64-5. quoted by Suy Iqt 67-9, cf Mubārak, 1974³, 102-17 
learned through the acquisitional norms (ilal ta limiyya). When we hear the expression inna zaidan qa' $\bar{a}^{\prime} i m u n$ (indeed, Zaid is standing) we know that after the particle inna the subject is in the accusative, and the predicate in the nominative. By analogy we apply this rule to other expressions of the same type. The illa qiyasiyya explains the rule by referring to the resemblance between the particle inna and the transitive verbs. If we then ask in which respect inna resembles the verbs, and why we compare it with the transitive verb, we need the 'illa gadaliyya wa-nazariyya (speculative and theoretical norm).

'Theoretical' (nazari) is evidently a calque of the Greek word theôrètikós, just as its counterpart 'practical' ('amali) translates praktikós. In the scholia on Dionysios Thrax, we frequently find discussions about the division of sciences; in this context the term theoretike téchnè denotes a science which explains by means of theory (lógos), and which investigates only with the aim of looking into something, examining something (theôrein) ${ }^{70}$ This is exactly how the term is used by, for instance, Yahyā ibn 'Adīi, ${ }^{11}$ and by Qusțā ibn Lūqā in his translation of the Placita Philosophorum. ${ }^{72}$ In the present context nazari indicates the sort of questions which aim at understanding the substance of the matter, and not at the practical use of it; practice is reserved to the 'ilal ta'limiyya, which teach you how to speak exactly according to the grammatical rules, without explaining the essence and the reasons of those rules.

The 'illa nazariyya is sometimes called 'illat al-illa; according to Ibn Ginni this 'illat al-'illa is not a real cause, but only an explanation of the linguistic facts. ${ }^{73}$ Ibn as-Sarrāğ says that there are two sorts of 'ilal: the linguistic rules that tell us how to speak (= Zağğāğì's 'ilal ta'limiyya); and the explanations of these linguistic rules, e.g. why it is that the subject always has the nominative case ("illat al-illa). However, we do not need to know this reason in order to speak correct Arabic. ${ }^{74}$ Obviously, in this system the ta lim represents the factor

70) Scholia D T 1, 20: 7, 13, 110, 23, 111, 32, 112, 23, 122, 29, 157, 29, 298, 2.

7 Yahyā tbn 'Adi in hıs On the four sctentific questions regarding the art of logic, ed. M Turker. Ankara Ünıversıtesı Dıl ve Tarıh-Goğrafya Fakültesi Dergısı, 14, 1956, 87-102, quoted by Rescher, 1966, p. 42.

72 Plac Phil , 2, 1-8

73 b Gin Has 1, 173-4, cf Mubärak, 19743. 122-3.

${ }^{74}$ b. Sarr ap Suy Iqt p 58, cf. Mubārak, $1974^{3}, 154$. C . the Skeptıc objection to the use of grammar, above, note 6; Zağğ Id 96, 17-9 'As for those of the common people who speak Arabic without declension, and yet make themselves understood, they can only do so when thıngs of common knowledge and dally use are concerned, 
natura, qiyäs and 'illat al-'illa the factor ars, which we will discuss below in connection with the theories concerning the origin of speech. ${ }^{75}$

In this connection we should also mention the story about al- $\underline{\text { Halil }}$ told by Zağğăğì. Al-Halīl, asked by somebody about his use of grammatical norms, answered: 'The Arabs speak according to their instinct and nature, and they know the structure of their speech. There is in their minds a solid knowledge about its norms (ilal) even if it is not related of them that they possess this knowledge. I considered something a norm whenever I was convinced it was the cause of what I considered its consequence'. ${ }^{76}$ In other words, the basis of every grammatical argument is what one hears from the Arabs; our explanations are mere guesses as to what is the reason for their using such-and-such a form. Although we know of other books about the ilal an-nahw - by al-Māzinīi, ${ }^{77}$ Quțrub ${ }^{78}$ and Ibn Kaisān ${ }^{79}$ Zağğāği claims to have been the first to write a book about this subject. $^{80}$

but if anyone of them would try to explain an ambiguity to someone else without understanding declension, he would not be able to do so' [A 53].

${ }^{75} \mathrm{Cf}$ below, chapter IX, note 29

76 Zağg. Id. 66, 1-2 [A 54].

77 Suy. Bugya, 1, 465 pen.

${ }^{78}$ Suy Bugya, 1, 243, 3, Fihrist, p. 53

79 Suy. Bugya, 1, 19, 8, this book is quoted by Zağǧăği, Id 50 , ult, under the title Al-muhtär, of Flugel, 1862, 209, n 2, Brockelmann, GAL I, 111; S I, 170

so Zağǵ. Id. 38, 13-6, cf. Mubārak, 1974³ , 69-7l 


\title{
THE PERIOD OF THE TWO SCHOOLS
}

\author{
'Arrange a meeting between Ahmad ıbn Yahyā and this \\ Bașrian ....'
}

According to the account of the Fihrist ${ }^{2}$ - which was adopted by Flügel ${ }^{3}$ - the history of Arabic grammar was dominated by the opposition between the Bașrian and the Küfan school, which ultimately coalesced into the school of Baghdad, also called the eclectic or the mixed school. This (simplified) account of the history of the schools was criticized by Weil in his introduction to Ibn al-Anbārī's Insaâf fi masāil al-hilä́f baina 'n-nahwiyyin al-bașiyyin wa-'l-kūfiyyin, and recently by Fleisch. ${ }^{4}$ Both regard the distinction as an artificial development invented by later grammarians. Their arguments may be summarized as follows: although there existed in Bașra and Kūfa two different groups of scholars with, probably, different opinions about grammar and about the various details of grammar, they did not consider themselves representatives of 'schools'. It was not even possible for them to do so because they did not meet each other very often, and had no chance to discuss their points of view, not even when they lived in the same city, as was the case with al-Mubarrad (d. 898/285) and Ta'lab (d. 904/291). The generation after Mubarrad collected the 'differences of opinion' (masā'il ihtiläfiyya), i.e. they projected their own differences of opinion into a former situation which never existed. The school of Baghdad, which is said to have been a fusion of the two systems, was nothing more than a conglomerate of grammarians, who, in retrospect, created the schools of Bașra and Kūfa: "Ainsi ces "Bagdadiens" sont les fondateurs de l'authentique école de Bașra et du fantôme d'école que fût $K u \overline{f a}$, car

'Zağğ Mağ 119, 9-10 [A 55]

${ }^{2}$ Fihrıst, ed Flugel : Basrians' 39-64, Kūfans. 64-77; man hlalara '/-madhahamı: $77-84$

${ }^{3}$ Flugel, 1862, the history of Arabic linguistıcs is discussed according to the triparttıon 'grammatısche Schule von Basra' (p. 3), 'grammatısche Schule von Küfa' (p 117), 'gemıschte grammatısche Schule' (p 183)

4 Well, 1913, 48-68. Flcisch, 1961, 11 sqq ; 33 sqq ; cr also Brockelmann GAL, S I, 157-8. 
il n'y eut qu'une veritable tradition grammaticale constructrice, celle de Basra qui mit du temps a prendre conscience d'elle même et comme toute tradition grammaticale a demande de l'effort de plusieurs generations pour porter ses fruits' 5 The Küfan school had only been created by the Baghdadians in order to give their own Basrian predecessors a worthy opponent Those solutions of grammatical problems which in the intiläf-literature are given as typically Küfan, are mostly derived from al-Farrā' (d 822/207), whose opınıons were used by the conservative Ta'lab in his struggle to lure pupils away from his personal rival Mubarrad in Baghdad, where grammar was concentrated from then on 'Eine Synthese der Gegensatze konnte nicht stattfinden, weil neben einem leidlıch ausgebildeten System nur die Summe eınzelner Entscheıdungen eines Grammatıkers, des Farrā oder hochstens noch des Kisāi stand' 6

We shall speak later about the school of Baghdad, ${ }^{7}$ here we shall try to modify somewhat this too severe criticism of the Arabic tradition, which tends to be too schematic and could be animated with the help of the varıous 'sessions of grammarians' (mağälıs), which dre reported for instance in the writıngs of Ta'lab, Zağğḡğì, and Ibn Ginni (d 1002/392), and which give us a glımpse of the ddily intercourse of the grammarians who belonged to the schools

In the first place, it seems very unlıkely $a$ prior that a fairly developed termınology as the one in use at Küfa should have been the work of one man, al-Farrāa' That such a specifically Kūfan termınology existed may be deduced from the writings of the Küfans themselves-we possess Farrā's Ma'äni 'l-Qur'ān and the Mağālis Ta'lab which show that these grammarians used the Küfan termınology very consistently - , and from later literature where we very often find the explıcit statement that such-and-such a term is Küfan ${ }^{8}$ Therefore, there can obviously be no doubt that there really was a typically Küfan terminology, which is confirmed by the following statement of Zağğăği 'We mention the following answer of the Küfans in so far as we have heard the arguments of those of the later grammarians who wished to support the Küfan doctrine, and also in so far as we read about it in their writings However, we replace their technical terms by our own, while preserving their meaning If we

5 Fleisch, 1961, 15

- Weil, 1913, 77

7 Cr below chapter VI

Bell, 1913, 72, n 1 a list of some of these terms, cf also Maḩzūmi, 1958, 303 sqq 
were to try to imitate their technical style in every single case, we would find it hard to hand down (their arguments to our readers), and it would not have any additional advantage. On the contrary, their technical language is probably for the greater part incomprehensible to someone who has not studied their writings'. We quote this passage in extenso, since it proves in itself that there did exist something like a Küfan tradition, unless we are to assume that later grammarians not only invented the Küfan school, but a special terminology to go with it as well. Besides, we find it hard to believe that a man like al-Fārābī (872/259-950/339), who was 32 years old when Ta'lab died $(904 / 291)$ should speak of a later invention, when he mentions what he calls the 'well-known dispute' about the question whether there exists a present tense in grammar. ${ }^{10}$ The problem how to explain this terminological difference between the two schools in terms of different grammatical and historical background is not relevant to our thesis that two more or less distinct 'schools' existed.

But there is more: the whole view Weil and Fleisch adopt with regard to the contacts between these various groups of grammarians is hardly commensurate with the numerous anecdotes which are told about the meetings between these grammarians. When we compare the 'sessions' in Zağğāğì's Mağălis al-'ulamā' with those in Ibn Ginnī's Hașá is ${ }^{11}$ and with the Mağalis Ta'lab, and then count how many instances of contact in oral discussion between two grammarians are recorded, we see how lively this contact was. It is true that the one recorded instance of a discussion between Sibawaihi and al-Kisāî (d. $799 / 183)^{12}$ seems to have been a special occasion, which was not to be repeated - afterwards Sibawaihi went to Persia never to return to Bașra!-, but on other occasions we find al-Kisā $\overline{1}$ in discussion with several other Bașrian grammarians: with Yūnus (d. 798/182), ${ }^{13}$ with 'Isā ibn 'Umar (d. 766/149), ${ }^{14}$ with al-Māzinī (d. 863/249), ${ }^{15}$ with

' Zağğ Iḍ 131, 15 - 132, 1 [A 56]

${ }^{10}$ Far Sarh, 40, 1-42, 26: on this questıon: Zağğ Id 86-8

11 Especially the chapter on the mistakes and the omissions of the scholars (bäh fi saqa!̣ät al-'ulamä'), b. Gin Has 3, 282 sqq.

12 b Anb. Ins 293, 2 sqq., Zağg̃. Mağ 8 sqq (although other discussions between the two of them are mentioned by Ibn Tagribardi, Flügel, 1862, 122). For this so-called mas'ala zunbūrıyya. Blau, 1963

13 Zağğ. Mağ. 21-2, cf. b Anb Ins 86, 2; Zağğ. Mağ 254, cf. b. Gın. Has 3, 291, 9 sqq ; b. Anb Ins 298 sqq., cf. b. Gin Has 3, 292, 7-8 and Zağğ. Mağ 244, Suy Buḡya, 2, 163, 9

14 Zağğ. Mağ. 148, 263

15 Zağǧ. Mağ 132-3, cf. b Anb Ins 81-4. 
al-Aṣma'i (d. 831/216). ${ }^{16}$ The grammarian Abū Muḥammad al-Yazidī (d. $817 / 202){ }^{17}$ even said: 'I put al-Kisā'ī to shame by proving his mistakes in nine questions in the presence of (the caliph) al-Mahdi'. ${ }^{8}$ The same holds true for al-Farrā', who is mentioned as having discussions with al-Garmī (d. 839/225), ${ }^{19}$ al-Așma ${ }^{2} \overline{1}{ }^{20}$ and al-Māzinī. ${ }^{21}$ Ta ${ }^{c}$ lab had discussions with al-Māzinī, ${ }^{22}$ and a rather heated altercation with one of Mubarrad's pupils, Zağğăg. ${ }^{23}$ Nor does the statement seem correct that 'même al-Mubarrad et Ta'lab qui vivaient tous deux à Bagdad n'ont engagé que de rares discussions orales', ${ }^{24}$ in view of the fact that we counted no less than six accounts of discussions between the two grammarians in Zağğăğì's Mağălis alone. ${ }^{25}$ Besides, we have Mas'üdī's statement that Mubarrad loved to have discussions with $\mathrm{Ta}^{\mathrm{a}} \mathrm{lab}$, although it is true that $\mathrm{Ta}^{\mathrm{a}}$ lab tried to avoid the contact for fear of Mubarrad's eloquence. ${ }^{26}$ His son-in-law, Abū 'Abd Allāh ad-Dinawari, attended Mubarrad's lectures in spite of his father-in-law's protests. All this is confirmed by the fact that Ta'lab speaks about the Bașrian and Küfan grammarians as existing groups and certainly not as divisions made up ad hoc by himself. ${ }^{27}$

Finally, al-Kisā'ī and al-Farrā' are quoted as discussing a manual, which the Küfans used in their grammatical education, called al-Faisal or al-Fașl. ${ }^{28}$ This proves that there existed something like a grammatical tradition in Küfa which cannot be explained away, and which

16 Zağğ Mağ 42;68, 336

17 On al-Yazidi Suy. Bugya, 2, 340, Brockelmann, GAL I, 110

18 Zağğ. Mağ. 173, 10-1, cf. also tb 169;255, 288.

19 b. Gin Has 3, 299, 11-8, cf b Anb Ins. 25, 9 sqq.

20 Zağğ. Mağ. 178

21 b Gin Haș. 3, 303, 4 sqq., cr. b. Anb. Inș. 216-7

22 Zağğ Mağ 104;112; 145.

${ }^{23}$ Zağğ Mağ 116 sqq

24 Weil, 1913, 53; Fleısch, 1961, 13

2s Zağğ Mağ. 107; 109; 115, 119, 124; 349 We have made a choice from the numerous examples, cf. also the parallel texts given in the introduction to the edition of the Mağălıs by A.M Hārūn.

26 Mas'ūdī, Murūğ, 8, 235; ad-Dīnawarī (d. 901/289): Flügel, 1862, 192

27 Ahlal-Bașra:Ta'l. Mağ. 1,44, 3, 1, 124, 4, 1, 249, 13; 1, 216, 7 etc ; al-basrıyyüna, ,b. 1, 58, 6. On the other hand: nahnu, ib 1, 178, 4, al-küfiyyūna, 1b 1, 106, 9, aş̣äbunā, tb $1,127,10 ; 1,196,3-4$, etc He also uses the expression Sibawaih wa-'l-Halil waashäbuhumā, ib $1,42,8 \mathrm{Cf}$ the meeting of Ta'lab with the ahl al-Basra, Suy Muzh. 2, 204, 15 sqq.

28 Zağg. Mag̀. 266, 269 Thıs work is ascribed to the 'founder' of Küfan grammar, Muhammad ibn al-Hasan ar-Rū'āsī, the teacher of Kısā'ì and Farrā' (d. \pm 805/190), cf. Suy. Bugya, 1, 83-4; Flugel, 1862, 18-9; Mahnzūmi, 1958, 77 sqq.; Brockelmann, GAL, S I, 177 . 
must have meant something to people like al-Mubarrad: he says of an amateur of grammar that he "longs for the grammar of these Küfans; they collect traditions and in case of disagreement refer to the books'. ${ }^{29}$ The words 'these Küfans' (häulä'i 'l-küfiyyina) express the same sentiment towards the rival group of grammarians as the words 'this Bașrian' (hāda 'l-bașrì) in the quotation at the head of this chapter.

How then must we regard these two 'schools'? Is it not right to assume the same rivalry to exist in grammar between the two cities of Bașra and Küfa as existed in questions of law and theology and in political and religious matters between them ${ }^{30}$ There is no reason to believe that Muslim universities differed very much from other universities : they were as proud of their own grammar and their own methods as contrasted with those of their rivals as any other 'school' in history. It is true that the resulting differences of opinion were mainly concerned with points of detail, and it is also true that the respective methods were not so different as they were made out to be in reciprocal accusations. As a matter of fact, the only difference between Bașrian and Kūfan grammarians was that they admitted different forms of words or verses; their handling of grammatical analogy was substantially the same, only their results were different. This shows that it would be a mistake to compare the two Arabic schools to the Greek schools of Alexandria and Pergamon-the advocates of analogy and anomaly in speech, respectively. Not only is there nothing that even remotely suggests a connection between the two developments, but there is also nothing that resembles the discussions about analogy or anomaly in speech in the controversies between the two Arabic schools: both agreed that the basis of language is the qiyass, grammatical analogy. ${ }^{31}$ We could, however, say that the Küfan school had the tendency to use a more or less rare grammatical phenomenon as evidence for an analogy, or to set up a superficial analogy in order to defend such a phenomenon, which is the reason why they were severely criticized by the Bașrians. ${ }^{32}$ But

29 Zağğ. Mağ. 119, 7-8; 'books' (kutub) probably refers to the grammatical wrıtings of the past [A 57].

$30 \mathrm{Cr}$. e.g. Mahzūmi, 1958, 65-6.

31 b. Anb Lum 44, 5-8. 'Know that the rejection of analogy is not justified, because the whole of grammar is analogy ... And whoever rejects analogy, rejects grammar itself. No scholar is known to have rejected analogy' [A 58]; cf. We1l, 1913, 29

$32 \mathrm{Cf}$ the references given by Weil, 1913, 29 sqq. (notes) On the accusation of irregular analogy: ib. p. 39 
on the other hand, it was completely normal for them to use arguments which consisted of two parts: one based on textual evidence and the other on analogy. ${ }^{33}$ Together with these criticisms we must keep in mind that it was more or less a standard procedure among grammarians to accuse the opponent of using an irregular analogy (qiyās 'alā 'š-šâd $\underline{\text { d }}$ ) based on forms which were not generally acknowledged. As the Küfan grammarians were more specialized in ancient poetry than their Bașrian colleagues ${ }^{34}$-like that great connoisseur of preislamic poetry, al-Mufaḍal aḍ-Dabbi, who was a Küfan (d. \pm 786 / 170)-, they attached greater importance to those forms which occurred in poetry even when they were contrary to the rules, and they were apt to use quotations from the poets to corroborate their theses. But on the other hand, they did not fail to use analogy as a (second) basis for their evidence. ${ }^{35}$

Without trying to play down the differences between the two schools, we have emphasized the fundamental agreement between them on the essence of language and grammar. As for the differences of opinion concerning details of grammar, this is not the place to discuss them. We refer to Weil's introduction to the Inșäf, as well as to Mahzūmī's study on the Küfan school. ${ }^{36}$

${ }^{33} \mathrm{C}$ e.g. b Anb Ins 68, 12-3

${ }^{34} \mathrm{Cr}$ e g. Fleısch, 1961, 27

35 In one instance analogy even serves as the sole basis for their argument, whereas the Basrians in this case rely on the evidence of quotations alone' (b Anb Ins 88).

36 Weıl, 1913; Mahzūmī, 1958; also Daif, 1968, 15!-242 The sort of confusion that arises around the character of the two "schools' may be illustrated by a few remarks made by Carter, $1973^{b}$ First he observes-in our view correctly-....1 peut avorr existé des écoles de grammaire répondant à la dérinitıon donnée par Schacht des "anciennes écoles jurıdıques", à savoır des groupes de savants se distınguant les uns des autres non par un corps de doctrine, mass simplement par leur implantation' ( $p$ 300), but then he repeats once agan Weil's opinion about the artificial character of the two schools, which Carter regards as a retrospective creation by Baghdadian grammarians, who attributed everything that contradicted Sỉbawaıhi's Kıtäb to Kūfan scholars (pp. 301 sq4 ) Regardless of these remarks he then tells us that the difference between the two schools may be expressed sımply and clearly Basra was prescriptıve, whereas Küfa was descriptıve' (pp 303-4) 


\section{THE INFLUENCE OF GREEK LOGIC}

'Some people, whose lables one should refuse to accept, think that those who are called the philosophers had a declension and grammatical writings of their own ${ }^{\circ}$

We have already discussed the transfer of cultural life in the 9th/3rd century to Baghdad and the consequences of this for Arabic grammar and linguistics. The 'mixing of the two schools' of Bașra and Küfa did not lead to a reconciliation of opinions-in this respect Weil and Fleisch are right-, it only brought together linguists from different groups, with the result that gradually the old distinctions between Bașrian and Kūfan grammarians disappeared. No longer did grammarians adhere to either the Bașrian or the Küfan system, but they were free to choose one of two existing opinions on any particular grammatical problem. This new development is described by Mubārak in the following way: 'Grammar in the (10th) 4th century in Baghdad did not become a grammar with different schools based on biases and emotions; the leaders followed their own various opinions, and some of them-like ar-Rummāni-followed their rationally founded logicotheological convictions, so that the influence of those convictions was discernible in their grammatical methods ... Their scholars used to study the theories of both schools and choose between them, without prejudice in what they chose: some of them usually preferred the school of Bașra, so that it became possible to call them a continuation of the Bașrian school in Baghdad; a few others became a continuation of the Küfan school; still others were Baghdadians, mixing the two sorts of grammar or taking from both of them'. ${ }^{2}$ This makes clear how it was possible for the old distinctions to disappear and at the same time to persist, not as a distinction between two groups of grammarians, but as a distinction between two different opinions. It also explains why a Baghdadian school suo iure never existed. The non-existence of a 'Baghdadian' school is one of the reasons for Fleisch to conclude that only at Baghdad did grammarians organize

\footnotetext{
' b Fàr Sāh 42,13-4. cf bclow, note 36
}

2 Mubārak, 196.3, 329-30 
themselves into two different groups, the 'Bașrians' and the 'Kūfans'. However, a 'Baghdadian' school could not even exist, because the grammarians in that city had at their disposal two conflicting opinions on almost every grammatical problem, and they could freely choose either one of them without subjecting themselves to any party discipline. It was only on those secondary points left 'unsolved' by the Bașrians and the Küfans, that they could advance a theory of their own-which is then mentioned as a theory of the 'Baghdadians', ${ }^{3}$ in so far as a communis opinio was reached on those points.

One could object that in that case there was no progress at all in Arabic grammar after its transfer to Baghdad. This, of course, is not true. Grammar then occupied itself with problems of a different nature to those of the preceding period. We shall have to distinguish between those elements that were old and constituted a legacy of the past, and those that were new. The latter category will concern us in this chapter.

The new generation of grammarians put to use the achievements of an older period to solve analogous problems. Their methods were more refined, although substantially their theories remained the same. More and more complicated problems were invented in order to have something to solve-this activity being one of the favourite pastimes of almost all grammarians: we need only refer to the eternal hairsplitting about the declension of unusual proper names, or about the construction of almost incomprehensible sentences. ${ }^{4}$ What is more, every grammarian was obliged to defend time and again the theory he had adopted about a specific problem, and he had consequently to invent even more ingenuous arguments with which to confound his adversary.

One could make yet another objection to this way of viewing the condition of Arabic grammar in the $9 \mathrm{th} / 3 \mathrm{rd}$ and the 10th/4th century: why was it so frequently Küfan grammar that was considered wrong, and why were the Küfan grammarians so heavily attacked? We could answer, of course, that the vast reputation of men like al-ㅂalil and Sībawaihi and of al-Mãzini and al-Mubarrad prevailed over the

3 Fleisch, 1961, 12 Such a specific theory of the Baghdadians is mentioned for instance, with respect to the nominative of the subject in a sentence like zaidun ahramIuhu (Zaid, 1 honoured hım) (b Gin $\underline{H}$ as 1, 199, 6 sqq), to a morphological question (b Gin Kıăh al-mugtaṣah, cd E Próbster. Leıpzig. 1904 (1968²), 3, 2, 4. 15), and to a phonetic question (the vocalization of the gutturals with an $a^{\circ}, 1 b .2,9,6-7$ ). cf Daif. 1968, 245-8

4 On proper names Zam Mul pp 5 sqq. and Flessch, 1961. 27l-5 On incomprehensible sentences Mub Muqt 3.89 sqq 
undoubted merits of Küfan grammarians. But another answer might be suggested. We must not forget that the Küfan grammarians did not consider themselves legislators of language, technical specialists, but rather amateurs of language and literature, collectors of interesting pieces of poetry. Such an attitude is tantamount to reducing one's importance as a scholar: one becomes an erudite, not a scientific investigator. If on the other hand, a grammarian wants to make himself indispensable, he has to emphasize his importance as a technical specialist, and he must pose as the possessor of a knowledge which is unattainable for the average layman. It is interesting to note that in this respect the schools of Bașra and Küfa resemble the schools of Alexandria and Pergamon, respectively: in both cases it was the most technical school that won the field and that had the greatest attraction for professional grammarians.

When we compare the grammatical treatises written before and after the transfer of grammar to Baghdad, we find an undeniable difference in mentality and approach. We have already mentioned the fact that later grammarians tried to defend the old theories with new arguments, and it is precisely in these new arguments that we find a lot of elements not present before in grammar. ${ }^{5}$ Above all, we find that the grammarians in Baghdad had a new set of grammatical notions at their disposal, or rather the same notions as before, but with a completely new purport, and defined in a new way. There now was an interest in the theoretical background of linguistic phenomena which was almost completely absent from earlier writings about grammar and language. Reflections about the origin of speech, for instance, are absent from grammatical literature until the second half of the 10th/4th century. ${ }^{6}$ There also arose a methodological concern to define grammatical categories according to the exigencies of logical law, and an awareness of the difficulties inherent in the organization of a system which is to comprise all known facts. Many of the subjects dealt with for instance in Zağğāğìs Ị̇ăh (e.g. the definition of the parts of speech, their hierarchy, the use of grammar, the reason why certain grammatical procedures are introduced into speech, the nature of declension, and so on) are typical of the discussions in this milieu. ${ }^{7}$ The fact that Zağğăği (d. 949/337) knew almost

5 The use of logic Zağg Id 48,9-10,59,13 (ahlan-nazar, 1 e those who use dialectıcal arguments) and below, chapter VII

6 Loucel, 1963, 197 (10), and below, chapter IX

7 By this 'milieu' we indicate the grammarians included in the second diagram on 
all grammarians of this period personally ${ }^{8}$ demonstrates the usefulness of his book for a better understanding of Baghdadian linguistics, especially when we use it to gain an insight into the logical foundation of grammar and its connections with Greek logic and philosophy. From bibliographical works we know that there were similar books by other grammarians, but they have as yet not been rediscovered, or they are still waiting for an editor or a commentator: the 'Ilal an-nahw of Ibn Kaisān, ${ }^{9}$ Ibn as-Sarrāğ's Kitāb al-mūğaz and his Kitāb al-ușūl, ${ }^{10}$ Rummānī's writings, ${ }^{11}$ the I⿳亠口冋h of Abū 'Alī al-Fārisī, ${ }^{12}$ and Sīrāfì's commentary on the Kitāb $b^{13}$ are examples of works which could solve a good deal of problems and uncertainties about this period of Arabic linguistics.

Some of the subjects which are found in the chapters of Zağğāğğ's I $d a$ a $h$ were also discussed by Greek grammarians, and when we compare their methods and their arguments, we find that there is a definite resemblance, above all in the use of logical terms in grammatical debates and the use of dialectical methods. There are grammatical points, too, which the two grammars share: some definitions of the nouns and the verbs: ${ }^{14}$ some of the arguments for the priority of the nouns $;^{15}$ the distinctions between two layers or levels of speech (impositions) $;{ }^{16}$ the question whether grammar is useful. ${ }^{17}$ The problem is from what sources the Arabs could have derived such knowledge.

pp 192-194. We refer to the exposé of Troupeau, 1962, who summarizes the most important facls about these grammarians and their works, and gives a short survey of the development of grammatical teaching in the 10 th/4th century.

" As he himself tells us, Iḍ. pp. 78-80

$\rightarrow$ Suy Bugiya, 1, 19, 8.

10 A manuscript of the Kiläb al-müğaz has recently been rediscovered in Morocco by Damerdıı and edited in Barrūt, 1965; c⿱ Brockelmann GAL I, 114

${ }^{1}$ On the writings of Rummānī: Mubārak, 1963, 87-92, Brockelmann, GAL I, 116 ; S I, 175 The main source for Mubārak's study was the Sarh al-Kıtäb, whıch has not yet been edited, of Fleisch, 1961, 35, n. 2; more data about the manuscripts of this work in Hadītî, 1967, pp. 204 sqq On Rummānīs theological writings: note 63 below.

i2 Three treatises by al-Fārısī, among them the Iḍăh have been discovered in the library of Lenıngrad University (ms. nr. 944), of Mamulija, 19652 Other manuscripts of the Idāh in the Dār kutub al-misriyya (ms. nr. 1006 naḥw; of Sāmarrāì 1971, 37-8, who refers to A I. Salbī, Abū'Ali al-Färısi Qāhira, n.d ) and cf Brockelmann, GAL, S I, 175-6. The first volume of this work has been edıted by $\mathbf{H} \check{\mathbf{S}}$. Farhūd, Qāhira, 1969.

${ }^{13}$ Cf Brockelmann, GAL I, 115; Hegazi, 1971; Haditīi, 1967, 159-92.

$14 \mathrm{Cf}$. chapter VII.

$15 \mathrm{Cr}$. chapter VII.

${ }^{16} \mathrm{Cf}$. chapter IX

$17 \mathrm{C}$ chapter VII. 
In this connection we think first of all of the translations of Greek philosophical works. In the first chapter we assumed that there was direct contact between the first Arabic grammarians and those among the people in the Hellenistic countries who knew Greek and had learned it through traditional grammar. It proved to be impossible to attribute the influence which at that time existed to the writings of Aristotle and his commentators because these had not yet been translated. But in the 10th/4th century there were Arabic translations of Greek writings: it was precisely in this period that the schools of translators flourished and that the Peripatetic writings were commented upon by Arabic philosophers, among them al-Fārābì, who died in 950/339, two years after Zağğāăḡi. All translatıng activities were concentrated in Baghdad, where the caliph al-Ma'mūn had, in about $830 / 215$ founded, or rather enlarged the Bait al-Hikma (House of Wisdom). About 25 years later, Hunain ibn Ishāq, the greatest of the translators, became director of this university, a function he held till his death in 877/264. Another important scholar, from the Saabian community in Harrān, Taabit ibn Qurra (d. 901/289) also came to Baghdad and brought with him all the accumulated knowledge of his community. About the same time, Qusțā ibn Lūqā, a Christian from Ba'labakk, was also working in Baghdad. ${ }^{18}$

But the classical tradition came to Baghdad not only via Syria. Meyerhof proved that the Alexandrian school was another link with classical antiquity. ${ }^{19}$ We know this from Arabic authors themselves: al-Mas'üdi (d. 956/345) still remembered something about the history of the Alexandrian school and its eventual transfer to the capital of the 'Abbāsid caliphate; ${ }^{20}$ this transfer took place, according to Mas'ūdī,

18 Brockelmann. GAL, I, 219-29 On Tāäbı ıbn Qurra Brockelmann, GAL, I, 241 4, S I, 384-6, Meyerhor, 1930, 403-4, 412, his Kitäb ad-dahira $f i$ 'Im at-libh was edıted by G Sobhy, Carro, 1928. On Qusțā ibn Lūqā Brockelmann, GAL, I, 222-4; S I, 3656: Meyerhof, Ib., Badawı, 1968, 190, Dasber, 1968, 3-5 The question of the Bait al-hikma is dealt with by Eche, 1967, 9-57. According to him the first institution of this name was founded under the Umayyads by Mu'āwiya, and continued by Yazid ıbn Mu'āwiya, who was also the first to further the translation of medical and astrological books Under the 'Abbāsıd caliphs al-Mansũr, al-Mahdī, and Hārūn arRašìd the collectıon of Greek books increased. But the apogee of the Bait al-hıkma was to be under al-Ma'mūn, who thought of hımself as a patron of the sciences, and who was interested in purchasing books in Byzantıum.

${ }^{19}$ Meyerhor, 1930

20 Mas'ūdi, Tanbih, 122, 2-5 ' (We have discussed) for what reason education was transferred from Alexandria to Antioch in the days of 'Umar ıbn 'Abd al-'Aziz, then it was transferred to Harrān in the days of al-Mutawakkıl; then it passed on to Quwairi and Yühannā ıbn Hailān in the days of al-Mưtaḍıd, and he (sc Yuhannā) died in Baghdad in the days of al-Muqtadır ...' [A 59]; cf Meyerhof, 1930, 407, Georr, 1948, 7. 
during the reign of the caliph al-Mutadid (892/279-902/290). Important in this context is above all the chronology: in the second half of the 9 th/3rd century, a large number of scholars came to Baghdad with a knowledge of Greek that was sufficient to translate fairly complicated philosophical works from Greek into Syriac and/or Arabic. And in the second place, there was a large collection of translated Greek logical writings at the disposal of those who could not read that language themselves.

It has generally been recognized that the translations played an important role in the history of Arabic culture, but the role of the translators has not been given the attention it deserved. That they knew not only Greek, but also the system of Greek grammar as it was still taught at that time at the Byzantine universities, seems selfevident. It is also confirmed by our sources. Hunain ibn Ishāa spent some years in Constantinople in order to study Greek ${ }^{21}$ - thus continuing the tradition of scholars like Jacob of Edessa-, ${ }^{22}$ and he himself wrote an Arabic grammar according to the Greek system. ${ }^{23}$ It is even said that Hunain wrote about Greek grammar. Excerpts from his Arabic grammar are probably given by $\underline{H}$ wārizmī. ${ }^{24}$ In later times, we hear that the Byzantine scholar Psellos even had among his pupils Galatians and Arabs. ${ }^{25}$ That this is no mere boast is proved by the fact that we have the name of at least one Arab from Baghdad who, according to an Arabic source, studied in Constantinople at this time (about 1050/440): Abū 'l-Hasan al-Muhtār, who was among the pupils of Psellos. ${ }^{26}$ If we accept Meyerhof's identification of the 'Theodosios' mentioned by al-Muhtār with the famous Alexandrian grammarian (first half 5th century A.D.), who in Byzantine times was one of the great authorities, ${ }^{27}$ we would have important evidence of the fact that at least one Greek grammarian

21 Qifti. Ta'rihh, pp 173-4; Madkour, 1969², 33; on Hunaın Brockelmann, GAL, I, 2247, S I, 366-9. Badaw1, 1968, 188-9 To be added to the biblography Meyerhof, 1926

$22 \mathrm{Cl}$ above, chapter I, note 20

23 Merx, 1889, 105-6.

24 Hwār Maf 46, 3-10; cf above, chapter II, note 10 Hunain and Halil: above, chapter I, note 49 According to Mas'üdi, Tanbih, 112, 15 sqq, Hunain translated the Septuagint into Arabic

25 Sathas, Mesaiônıkè Bibliothèkè, Venice, 1872-94 (1972), 5, 508; Krumbacher, $1897^{2}, 433$.

${ }^{26}$ Fuchs, 1926, but cf. Peters, 1968, 25 On Abū 'l-Ḥasan al-Muhtār 'Wüstenfeld, 1841, nr. 133, cf. Meyerhof, 1930, 426.

27 Meyerhof, 1930, 397, Hilgard, Grammatici Graect, IV, I, V-IX 
was known in the Arabic world. Al-Muhtār could have heard about Theodosios during his studies in Constantinople.

In fact, it seems altogether possible that contact in cultural and scientific matters between the Byzantine and the Muslim world was more regular than is normally assumed. To mention only one example: the mission of the famous apostle of the Slavonic peoples, Kyrillos, to the Saracenes. This mission took place in the second half of the ninth century A.D. Kyrillos was interested in grammar, as is evident from his translations of grammatical works-one work is mentioned about the eight parts of speech-, his study of the Hebrew and the Samaritan language, which he could read fluently, and, of course, by his work on the Slavonic alphabet. ${ }^{28}$ It seems rather improbable for such a man not to have engaged in linguistic discussions with his Muslim colleagues. ${ }^{29}$ There is also the matter of the theological discussions between Muslims and Byzantine Christians, which continued throughout the Arabo-Byzantine conflict and acquainted the Arabs with many elements of Greek philosophical and logical doctrine. ${ }^{30}$

Besides, we must keep in mind that precisely this period witnessed a revival of science and art in Byzantium under the oikoumenikos didáskalos of the patriarchal academy, Photios (d. $\pm 891 / 278) .{ }^{31} \mathrm{We}$ wonder if there could be a correlation between this 'Byzantine renaissance' and the sudden interest in Greek science in Baghdad. This hypothesis should be studied in the light of the Arabo-Byzantine political relations in the 9th/3rd century. ${ }^{32}$ Anyhow, these relations

28 On Kyrillos: Dinékov, 1972, Bujnoch, $1972^{2}, 63-8$; the authentıcity of this missıon has been questioned, ib p 195, n 45

29 We could also refer to Photios' (d. \pm 891/278) embassy to the 'Assyrians' in $855 / 241$, durıng which he collected materials for his (Greek) anthology, cf Peters, 1968, 23, Hemmerdinger, 1956; RE XX, 1, 677;689

${ }^{30} \mathrm{Cr}$ above, chapter I, note 9; Vryonis, 1971, 421-36

31 Vasiliev, $1970^{2}, 63-8$, on Photios : Krumbacher, $1897^{2}$, 73-9; 515-24; Peters, 1963, 23; Dvornık, 1950 Speck, 1974, argues convincingly against the existence in Byzantıum of a state university: the schools of higher education were private institutions with different levels of teaching They received financial support of a private person--who might even be the emperor himself, as in the case of Konstantınos ${ }^{-}$VII Porphyrogenıtos $(913 / 301-956 / 355)-$, but they were never part of any official educational system Accordıng to Speck, the oikoumenıkos didáskalos was not connected with any 'university' or 'academy' at all (ib. 74-91). For our purpose, however, this correction of the tradition is irrelevant : whether these schools did or did not possess an official status, their cultural importance remained the same.

32 Vasiliev, 1935-68; Canard, 1973, a collection of articles; particularly interesting are Quelques à coté de l'historre des relations entre Byzance et les Arabes (1956); La prise d'Héraclée et les relatıons entre Härün al-Rashid et l'empereur Nicéphore ler (1962); Les relations politiques et sociales entre Byzance et les Arabes (1964). 
were friendly enough to enable Arab caliphs to send for Greek manuscripts to Constantinople-which is reported about al-Ma'mūn and al-Manșūr. ${ }^{33}$ And, in times of war, there always was an opportunity of obtaining Greek manuscripts in the course of a military expedition: aššsāfi'i recommends the translation of such manuscriptsthough only if they contain 'medicine or useful sciences'! ${ }^{34}$

However, except for the possibility that Theodosios the grammarian was mentioned by al-Muhtār, no names of Greek grammarians are given in Arabic literature. This point is emphasized by Gätje as a serious setback for any theory which tries to explain the resemblances between Greek and Arabic grammar by supposing a contact between the two cultures. ${ }^{35}$ The explanation could be that the general attitude of Arabic scholars towards foreign culture was rather negative; thus, for instance, Ibn Fāris: 'Some people, whose fables one should refuse to accept, think that those who are called the philosophers (i.e. the Greek philosophers) had a declension and grammatical writings of their own. Ahmad ibn Fāris says: we do not go in for that sort of talk'. ${ }^{36}$ We do not assert that all grammarians were as chauvinistic and narrow-minded as Ibn Fāris, but certainly the belief in the superiority of the Arabic language and Arabic grammar was very strong among them. ${ }^{37}$ This could be the reason why grammarians did not mention any Greek grammarian.

There is one instance of a Greek name mentioned in connection with grammar, namely in the notes of al-Hasan ibn Suwār (born in $942 / 331)^{38}$ on the Arabic version of Aristotle's Categoriae. To Aris-

${ }^{33}$ Hittı, 1968', 309 sqq We may also mention the case of Leon Philosophos one of his pupils had been taken prisoner by the Arabs, and the calıph al-Ma'mūn, amazed by his knowledge, tried-unsuccessfully-to obtain the services of Leon at the caliphal court. Theophanes continuatus, 189-90, Speck, 1974, 2, 4, note 17.

${ }^{34}$ Meyerhof, 1933, 122, n 2; Sàlíi ap. Tabari, Ihluläf al-fugahä' Ed Schacht Leiden, 1933, 178, 28 sqq

35 Gatje. 1971, 23

36 b Fār. Sāh 42, 13-5 [A 60]

${ }^{37}$ b. Fār Sāh 42, 6; also. Zağğ. Id. 45, 3-5; Sığıstānī ap Tauh Muq. pp 293-4; Tauh Imtā', 1, 76, $13-78,5$ (cf. Bergé, 1972); of the critıcal remarks of Ibn Hazm, Ihk $1,32,8-10$

${ }^{38}$ On Ibn Suwār: Brockelmann. GAL, S I, 378 (Ibn Sıwār), Badawı, 1968, 192; Meyerhof, 1930, 421 He was born in 942/331, and was a pupil of another famous translator, Yahyā ıbn 'Adi (Brockelmann, GAL I, 228, S I, 370), he died after 1017/408. Ibn Suwār not only gives his own comments on the Categoriae, but also translates sometımes or gives paraphrases of Greek commentaries He quotes Ammonıos by name (369.8 sqq) and gives paraphrases of parts of his commentaries in a number of passages (361, 14-22 and 363, 2-3, cf. Ammon. pp. 11-2, ed Busse, 366, 11-4, of Ammon 17, 
totle's words '... like, for instance, grammar, because it has the mind as its substrate', he adds '... as for instance Sibawaihi with the Arabs, and Sūsiānos (?) with the Greeks'. ${ }^{39}$ We have sought in vain to fit the name into a form which is more likely to be a Greek name; maybe the person meant is Johannes the Grammarian (Johannes Philoponos), ${ }^{40}$ but he was a philosopher, not a grammarian.

Fortunately we at least have evidence that al-Fārābì knew and even studied Greek grammarians. Speaking about a group of words, he says: 'Those words form a part of the group of significant words, which are called by the grammarians hurüf, and which are used to denote meanings. These hurüf are also divided into many sub-divisions, although the experts of Arabic grammar have not been accustomed so far to giving a special name to each sub-division. So, in defining these sub-divisions, we will have to use the names which reached us from the grammatical experts of the people of the Greek language, since they gave each sub-division its own name'. ${ }^{41}$ We have studied above these various types of hurüff. ${ }^{42}$ Gätje studied al-Fārābī's Kitāb al-alfáz al-musta'mala $f \mathfrak{i} \cdot l$-mantiq, where this quotation is found, and

18 sqq ) According to Walzer, $1963^{2}, 74-5$, it is not necessary to assume the existence of a commentary previous to Sımplıkıos as Ibn Suwār's ultımate source, sınce hıs references to edrlıer commentaries are also found in Simplıkıos (so, for ınstance, b Suwār, 369. $8 \mathrm{sqq}$, cf Simpl in Aristot categ 18,9 sqq ed Kalbfleısch) But this does not apply to the important passages about the theory of the "first and second imposition', which exercized $d$ considerable influence on the Arabic theories about the nalure of speech, cf below, chapter IX We can also mentıon Ibn Suwār's use of the word halantür as an example of a meaningless expression this word is identical with the Stoic blituri (SVF 3, 213, 21, the word was also used by the Aristotelian commentators) It would be very interesting to have at our disposal all notes written by Ibn Suwār in the manuscripl of the translation of the Organon (Bibliothèque Nationale ar 2346), cf Georr, 1948, 190, Kraus, 1942, 2, 251, n 2

39 Text Georr, 1948, 320, 5-6 = Arıstol categ 1 a 25-6, notes b Suwār, 378, no 44 [A61]

40 Süsiänos must be d mistake, the only possible emendation I can think of is Johannes spelled in the Greek form, not in the Arabıc Yühannā (1 e $y-n-h-{ }^{-} n-s$, instedd of the text given by Georr,$-n-1-y-\cdot-n-s)$, just as the name Hippokrates occurs in two forms the current form Buqrăt, and an earlier form Hi/üqratis, in the wrılıngs of Yūhannā ıbn Māsawdıh (Walzer, 1963², 112) Johannes Phıloponos, the Alexandrian philosopher, was known in the Arabic tradition as an-Nahui (the Grammarian), he lived in the first half of the 6th century A D Krumbacher, 18972, 581-2, Stcinschneider, 1960², 141-3, Meyerhof, 1930, 397, Qıftī, Ta’rīhn, 356, 14, Meyerhof, 1931. Salfrey. $1954 \mathrm{He}$ is probably the Philoponos whose words are quoted in the scholıd D T $(547,24$ sqq, of also 524, 11$)$ concernıng the question whether the nomındtIve is d case, $\mathrm{cl}$ also below, chapter III B, note 14

41 Far All 42, 7-12 [A 62], cf Sarh, 54, 9

42 C chapter III A 
found many traces of Greek grammatical doctrine: 'Gesichert ist auch durch die eigene Aussage al-Fārābī's und die vorangehende Gegenüberstellung ein Einfluss der griechischen Grammatiker. Die genaue Quelle ist unbekannt. Es scheint aber, dass al-Fārābī mehr wusste als in der Téchnè grammatikè des Dionysios Thrax steht'. ${ }^{43}$ We may also refer to Fārābì's description of grammatical treatises, which shows many traces of the Greek téchnai peri hellenismo $\hat{u}^{44}$ All this proves that logicians and philosophers in the 9 th/3rd and the 10th/4th century not only translated Greek writings, but also occupied themselves with Greek grammar-which, of course, they had to do, if they wished to gain some understanding of the Greek language.

One could, however, object that this does not prove that Arabic grammarians were as interested in the problems of another language as the philosophers. It may not even prove that they knew these problems, but it is a fact that there was a lively, though not always friendly contact between representatives of logic and grammar in the 10th/4th century. One well-known discussion is that between as-Sïrāfi (d. 979/368) and Abū Bišr Mattā ibn Yūnus (d. 970/360), which took place in 932/320.45 This discussion-the text of which is preserved for us by Yāqūt and at-Tauhīíi ${ }^{\mathbf{4 6}}$ —does not offer a detailed account of the grammatical matters which were discussed, but it does give a marvellous picture of the relations between the old-fashioned grammarians with their empirical ${ }^{47}$ logic of sound reasoning and common sense, and the enthusiastic representatives of the new Aristotelian way. These modern logicians were proud of their knowledge of antiquity, and had a deep admiration for the philosophy of the classical thinkers. ${ }^{48}$ They were convinced of the superiority of Greek wisdom (and language), a conviction which is also found in the works of another philosopher, Muḥammad ibn Zakariyyā Rāzī (d. 925/313). ${ }^{49}$

${ }^{43}$ Gätje, 1971, 23

$44 \mathrm{Cr}$. above, chapter III B.

45 On thıs discussıon: Mahdı, 1970 Mattā ıbn Yūnus. Brockelmann, GAL. I, 228, S 1, 370, Meyerhof, 1930, 415-6; Badawı, 1968, 190.

4h Yàqūt. Irsīäd al-arih, ed D.S Margolıouth, Cairo/Leiden/London, 1907-27, III², 84 sqq , Tauh. Imtā', 1, 108, $5-128,19$.

47 An example of an attested empirical argument is the argument that if Aristolle had really been so important as claimed by Mattā, then one could dispense with all other logic (Mahdı. 1970, 80), cf. Galenos, On medical experience Walzer, 1944, 101 , cf. Mahdı, 1970, 68, Tauh Imtā: 1, 113, 6-9; cf below, chapter IX, n 6.

48 E g Mattā ıbn Yūnus, Mahdı, 1970, 67

49 Ràzí. Opera Philosophica, 1, 42, 14-5 'We also found as a generally valıd matter that none of all other nations has a more subtle flatr, nor a more manifest wisdom than the Greek natıon [A 63] 
The grammarians, on the other hand, deemed themselves capable of solving any problem with the help of their universal science of grammar, whereas, according to them, logicians were always bound to a single language: 'Grammar is logic, only it is detached from Arabic; logic is grammar, only it is understood through language', so says Sirāfi in the course of the debate. Conversely, we find the following words of a representative of the new logic, as-Siğistāni (d. $\pm 985 / 375)$, the teacher of Tauhìī: 'Grammar is an Arabic logic, but logic is a rational grammar. The opinion of the logician is decisive about meanings ... and the opinion of the grammarian is decisive about expressions'. ${ }^{51}$ The same distinction is found in Färābìs Ihṣa $\bar{a}^{\prime}$ al-ulüm, where he tells us ${ }^{52}$ that grammar is concerned with those expressions that are specific to one single language, whereas logic gives rules which apply to the expressions of every language, in other words, universal rules, which are indispensable to any science, even the science of grammar. The idea of logic as a standard for all sciences is developed especially in the philosophy of the Stoics, who considered logic as one of the criteria of truth. ${ }^{53}$ It goes without saying that Arabic grammarians resented this claim of the logicians: they tried to claim the same position for grammar. The grammarian whom Muhammad ibn Zakariyyā met in Baghdad was so proud of his knowledge and wisdom, that in the end he even said: "This (sc. grammar) is the only science, the rest is wind"! ...; for he was one of those who think that when you are skilled in language, you are able to answer every question'. ${ }^{54}$ The problems which were so vehemently discussed by the two factions even found their way into technical grammatical writings. ${ }^{55}$ Examples of this kind of discussions are

so Mahdı, 1970, 72, Tauh Muq, 75, 2-3 [A 64].

51 Tauh. Muq 170 penult -ult [A65]; cr. 177, 16-22

s2 Far Ihsā, 35, 1 sqq Such discussions about the difference between grammar and logıc were also the subject of the Kitäb tabyin al-faṣl haına sinäatayı $/$-montıq al-falsafì u'a-'n-nahu al-arahi by one of Fārābï's pupıls, Yahyā ibn 'Adi, cf. Qıfti, Ta'rih. 362, 2, Kraus, 1942, 2, 251, n 2 As-Sarahsī, a pupıl of al-Kındi, wrote about Al-farq baina nahn al-arab wa-l-mantı, of ba Usabbia, I, 215; Kraus, ib On Sarahsī- Brockelmann, GAL. I, 231-2: Rosenthal, 1943; 1951 For the discussions concernıng the relationshıp between grammar and logıc. Mubārak, 1963, 228, 19743, 72-8

${ }^{3}$ SVF, 2, 19, 33 sqq. , 2, 20, 15-8 On the problem of the place of logic withın phılosophy: Jadaane, 1968, 100-6; Fārābi ap. Dunlop, 1951, 92-3.

54 Rāzí, Opera Phılosophica, 1, 43-4 [A 66]

ss For instance, the question if the expression zand ahıan ılıu'anihı (Zaid is the best of his brothers) is correct or not, cf Mahdi, 1970, 76, as compared with b Gin Has 3, 24, 4 sqq.; 3, 333, 8 sqq ; 3, 336, 8-10 and with Hariri, Durrat al-gawäss, ap de Sacy, 1829,25 penult $-26,7$, cf. $p$ 64 This is the problem of the adjunction of something to 
abundant in Tauhidì's reproduction of the conversations which asSiğistāni held with other scholars in the booksellers' quarter in Baghdad. ${ }^{56}$ His opponents were not as obsessed by professional pride as as-Sīrāfí, though.

On the whole, there is no reason to suppose such a state of enmity and rivalry to exist between logicians and grammarians as we are led to believe from the foregoing remarks. A striking example of good cooperation is the arrangement al-Fārābi had with the grammarian Ibn as-Sarrāğ (d. 928/316): the grammarian learned music and logic from the logician, who in his turn studied grammar with the grammarian. ${ }^{57}$ At an earlier time we find the logician-philosopher al-Kindi (d. \pm 873/260) visiting Bașra and discussing with al-Mubarrad a linguistic problem. ${ }^{58} \mathrm{We}$ may also refer to Zağğāğì's repeated assertion that he tries to deal with his subjects according to grammatical standards, and not according to the theories of logic ${ }^{59}$ - which is typical for the need of his time to distinguish carefully between grammatical and logical ideas and opinions.

This is also confirmed by the fact that not everyone succeeded in making the distinction between grammar and logic which Zağğăği feels is necessary. More than once we find the grammarian accused of mixing grammar with logic. We have already mentioned Ibn asSarrāğ, who studied with al-Fārābī; from what we know about his grammatical work, we may deduce that logic indeed did have a lasting influence on his ideas about language; he used logical terms, and rearranged the traditional facts of grammar according to logical theory. ${ }^{60}$ It seems very probable that Ibn as-Sarrāğ was one of the primary sources in transmitting the logical materials from his teacher al-Fārābi to the Baghdadian grammarians, since among his pupils were az-Zağğāăì, al-Fārisī, as-Sīrāfi, and ar-Rummānì. We certainly do not

itself (ıdäfat aš-šay' $\iota \bar{a}$ nafsthi), whıch is mentıoned as a matter of disagreement between the Basrians and the Küfans (b Anb Ins. 181-2; Asr. 11, 9: the Küfans allowed this adjunction, whereas the Bașrians rejected it; cfr. 'Ukb. Mas. p. 111). The same point is touched in the discussions about the identity of ism and musamma, cf below, chapter VIII, note 37

${ }^{36}$ For Instance in his Muqābasāa; Tauhidi was a pupil of ar-Rummāni, the logiciangrammarian.

57 Kraus, 1942, 2, 251, n 2 on the authority of b a. Ușaibi'a, 2, 136

58 The discussion between Mubarrad and Kindi concerned the question if the word inna is a superfluous word, $\operatorname{Rāzi}, \operatorname{Ma} 2,42$ ult. - 43, 4.

s9 Iḍ 48, 8-16; 58, 6-13, cf. Mubārak, 1974³, 102-17.

${ }^{60}$ b. Anb Nuzha, 150, 7-8; Qiftī, Inbāh, 3, 149; Fihrist, ed. Flügel p. 142; Suy Buġya, 1, 109-10, cf. Amer, 1963, XVIII-XIX. 
assert that each of these grammarians was as devoted a logician as Ibn as-Sarrāğ was, but somehow they contributed all of them to the influence of logic on grammar, if only because they mentioned certain logical terms or theories.

As for ar-Rummāni, he carried on the tradition of his teacher, Ibn as-Sarrāğ, and even went so far with his logical studies, that it caused him to be accused of making a mixture of logic and grammar, which was incomprehensible to normal grammarians. ${ }^{61}$ We know, moreover, that ar-Rummāni was a Mutazilite. ${ }^{62} \mathrm{We}$ shall see below that most Baghdadian grammarians belonged to the Mutazila or had connections with that group of philosophers - which could explain their interest in things logical. Rummāni also wrote about the most important problem of Mu'tazilite theology: the creation of the Qur'ān and the incomparability of its style (notably in his Kitäb an-nukat fi $i^{\prime \prime}$ gă al-Qur'än). ${ }^{63}$ Both subjects had much in common with grammar and linguistic philosophy, as we can see in the writings of that great Mu'tazilite, 'Abd al-Gabbār. The discussions about the creation of the Qur'ān were closely linked with the problem of the creation of speech. ${ }^{64}$

We have come to know as-Sirāfi as a fierce opponent of the new logic, but even he did not escape its influence. He, a pupil of Ibn as-Sarrāğ and of the famous Mu'tazilite al-Gubbā'ì (d. 915/303), spent much of his time studying Greek authors-among them Ptolemaios and Eukleides-, and also devoted his energy to the study of logic, in spite of his opposition to Mattā ibn Yūnus. As a matter of fact, his opposition was not directed at logic in general, but against the new, Aristotelian logic, as it was being preached by Mattā, and against its extravagant claims to supremacy in science. ${ }^{65}$

Yet another scholar of this period, Ibn Kaisān (d. 932/320) probably wrote about both disciplines: his definition of the noun was given in two versions, a grammatical one, and a logical one according to the Aristotelian tradition, as we know from Zağğăği ${ }^{66}$ It is typical of the

61 b Anb Nuzha, 189-90; Suy Bugya, 2, 181, 3 sqq

$62 \mathrm{Cf}$ below, chapter V111, note 18

${ }^{63}$ For Rummānìs activities in this field Bouman, 1959, 45-7, Nader, 1956.

${ }^{64} \mathrm{C}$ r below, chapter IX.

6s Zub. Tab 132, 12-4. On the distinction between Sirāifi's logic and the logic of Mattā ibn Yūnus: Mahdı, 1970, 58 sqq On Sìrāfĩ: Brockelmann, GAL, I, 115, S I, 174-5, Hegazi, 1971.

66 Id. 50, 11-6. 
scholars of his time that they forgot about the ancient differences between Bașrian and Küfan grammar. Sīrāfí tells us so explicitly about Ibn Kaisān ${ }^{67}$ and about two other teachers of Zağğāğì, Ibn Suqair (d. 929/317) and Ibn al-Hayyāṭ (d. 932/320). ${ }^{68}$

The influence of pure, mostly Peripatetic, Greek logic remained preponderant in the logical works of Arabic philosophers. Many of the ideas and terms of the Aristotelian tradition are found for instance in Gazzālī's works, such as the Kitäb al-maqșad al-asnā fi asmä' Alläh al-husnā, the Kitäb al-mustasfä, the Mïyär al-'ilm, and the Kitäb al-ma'ärif al-aqliyya. ${ }^{69}$ We may also refer to Ibn Hazm's Kitäb at-taqrib li-hadd al-mantiq ${ }^{70}$ and to the section about logic in Hwārizmìs Mafätih al-'ulüm. But the most important contribution to our knowledge of Aristotelian logic in the Arabic world comes from Ibn Sinā's commentaries and from the works of Fārābi: notably his commentary on the De Interpretatione, and the section about logic in his $I h s s \bar{a}$ al-ulüm. ${ }^{71}$ From these writings Aristotelian logic found its way to grammar, though it never succeeded in replacing completely the earlier influence of the direct contact with Greek grammar.

It should be noted that with the introduction of Greek logic other elements besides the Peripatetic theory were brought to the Arabic world, among them Stoic elements. This applies for instance to Stoic materialism, which had a strong influence on the $\mathrm{Mu}^{\text {'tazilite philos- }}$ opher Nazzām (d. 845/231) and which is also discernible in the

${ }^{67}$ Sìr Aḥb 108, 8-9 Both Ibn Kaisān and al-Aḥfaš aṣ-Sagìir (= Abū l-Ḥasan 'Alì ibn Sulamān, d 917/305) attended the lectures of Mubarrad and Ta'lab, the two rivals and representatives of the school of Bașra and $K \bar{u} f a$, respectively It is typical that the Fihrist begins its analysis of the later grammarians with the words the names and the biographies of another group of learned grammarians and lexicographers, namely those who mixed the two schools' (asmā' wa-ahbär gamäa min 'ulamä' annahwlyyin wa-'l-lugaw'yyin mimman halata $\%$-madhabain) $77,8-9$, cf Flugel, 1862, 183 sqq.

68 Sìr Ahb. 109, 2-3, cf Zağg. Iḍ. 79, 3-6

${ }^{69} \mathrm{Cr}$ Brockelmann, GAL I, 535-46, S I, 744-56 (nos. 5, 51, 62, 54); Brunschvig, 1970, 158-69. On the Asmā'. Gätje, 1974 We have used the edition $\mathbf{M}$ al-Kutubi, Cairo, 1324 A.H, the most recent edition is by F.A. Shehadı, Beyrouth, 1971. Two other ımportant logical works by Gazzāli are the Magäsıd al-faläsıfa, GAL ib. no. 56 (we have used the edition M.S al-Kurdi, Cairo, 1331 A H ; there is a more recent edition in three volumes, Carro, 1936) and the QIsiās al-mustaqim GAL ib. no. 28 (1d. V. Chelhot, Beyrouth, 1959), of Kleinknecht, 1972.

70 Brunschvig, 1970, 150 sqq.

71 Brockelmann, GAL, I, 589-99; S I, 812-28 (Ibn Sinā), GAL I, 232; S I, 375-7 (Fārābī). 
theories about the nature of sound. ${ }^{72}$ The theory of meaning and the Stoic traces found in it will be discussed below, as well as those Stoic elements which are present in Arabic grammatical theories. ${ }^{73}$

${ }^{72}$ Horovitz, 1903, 1909. For the connection between the materialism of the Stoa and the theories on the nature of sound: cf chapter II, notes $44,69,70$.

${ }^{73} \mathrm{Cr}$. below, chapter $\mathrm{X}$. 


\section{THE USE OF LOGIC IN GRAMMAR}

'These are not grammatical terms or 1ssues, but they are taken from the technical language of the logicians, although a number of grammarians did accept them'. ${ }^{1}$

Just like the Greek commentators on Dionysios' Thrax Téchnè 10th century Arabic grammarians tried to give their grammatical writings a learned image by using logical arguments, philosophical terms, and dialectic methods; in both cases the results were not always fortunate. Zağğăği is typical of this trend in Arabic grammar. He evidently believes that reason precedes religious tradition: he was, after all, a Mu'tazilite; ${ }^{2}$ he is also convinced that knowledge is developed through reason, and that it is not innate, because that would extremely limit man's free will, and his responsibility for his own acts. ${ }^{3}$ We may, therefore, expect him to be influenced by the logical theories of his time. On the other hand, it is obvious that he sincerely tries to keep logic and grammar separate, although he does not always succeed. ${ }^{4}$ In this chapter we will quote a few examples from Zağḡăğìs Iḍah to illustrate the use of logic in grammar.

In the second chapter of the I $\not \overline{d a} h$ there is a discussion about the definition of 'definition' and of 'philosophy'. Such discussions were typical of the kind of grammar that was in vogue at Zağğàğì's time. They are also typical of the scholia on Dionysios Thrax: all scholia begin with definitions of téchnè, 'definition', etc. ${ }^{5}$ In his discussion Zağğāḡì followed Fārābīs introduction to Porphyrios’ Eisagôgè. ${ }^{6} \mathrm{He}$

1 Zağğ. Id. 48, 11-2 [A 67].

${ }^{2} \mathrm{Cr}$ below, chapter VIII, note 19 On Mu'tazılıte ratıonalısm: Bernand, 1972, 38; Brunschvig, 1972; Houranı, 1971

${ }^{3}$ Nader, 1956, 239-58

4 Zağḡāğı̀'s attıtude towards logıc. Mubārak, 1974³, 102-17

s E g. scholı D T 2,19 sqq. + 3,10 sqq , 107, 1 sqq $+108,27$ sqq., 156, 28 sqq. + $157,15,297,17 \mathrm{sqq}$

${ }^{6}$ A translation of this (unpublished) introduction. Dunlop, 1951 According to Dunlop Fārābīs introduction to Porphyrios' Eısagôge may have been based on Philoponos' introduction to philosophy, which borrowed frequently from Ammonios, but is not preserved (Dunlop, 1951, 78). Zağgāăgi follows Fãrābì closely in hıs discussion about the definition of philosophy 
mentions three definitions, the first of which is the one preferred by Fārābi. ${ }^{7}$

1. The first definition-'a definition is a concise way of expressing the nature of the thing to which it is applied'-is a literal translation of the definition which is given in the Greek scholia, without any indication of the source. ${ }^{8}$ The word 'concise' (suntomos) in the Greek texts suggests a Stoic origin, when we take into account the importance of the notion 'conciseness' (suntomia) in the Stoic system of the virtues of speech. ${ }^{9}$

2. The definition chosen by Zağğăği is that of the Aristotelian school: 'Definition is what expresses the essence of a thing' (logos ho to tí én einai sèmainon $)^{10}$ This definition was also quoted in Greek grammatical writings. ${ }^{11}$ In the Arabic world, it was avoided by orthodox theologians because of its connotation of a causal relation between the object defined and the decisive terms used for defining its nature: theologians used a descriptive type of definition instead (cf. Zağğāğì's third definition). Zağğāğ̄i, of course, does not have such qualms about causality, and therefore uses the Aristotelian type of definition, in accordance with his logical and Mu'tazilite leanings, although in practice he acknowledges the value of a descriptive definition. ${ }^{12}$

3. The type of definition favoured by the theologians is the description (rasm), about which van Ess observes: 'One was not primarily concerned with the problem how to find out the essence of a thing, but rather how to circumscribe it in the shortest way so that everybody could easily grasp what was meant'. ${ }^{13}$ In other words, the aim of the description is to differentiate the object to be defined from other objects resembling it, by mentioning a characteristic property it does not share with any other object. In Fārābīs words: 'Both (sc. the definition and the description) share the use of the genus of the thing, and they differ in that the definition

7 Zağg Id. 46, 6-11, cf. Far ap Dunlop. 1951. 82-4

- Scholid D T 107, 20-1 [G 38], 157, 4-5

9 Barwick, 1922, 95, Diog Laert 7, $59=$ SVF 3, 214, 16-7

${ }^{10}$ Aristot top 1, 5, 101 b 39

1 E g scholia D T 107, 1-2

$12 \mathrm{Cr}$ his discussion concerning the definition of philosophy (Id 46, 12 sqq), also his answer to the criticisms agaınst Mubarrad's descriptive definition of the noun, Id. 51, 4-6

13 van Ess, 1970, 38 
adds to the genus the substantial differentiae, while the description (adds) the accidental differentiae' ${ }^{14}$

It is this type of definition which Zağğāğ refers to when he talks about the differences between the various definitions of 'philosophy': in his view, definitions may indeed differ, since they are made for different aims. ${ }^{15}$ It is evident that this type of definition is related to the Stoic 'description' (hupographè), which is defined by Chrysippos as 'showing the characteristic properties' (hè toû idiou apódosis). ${ }^{16}$

Every art should have its ultimate justification in that it is useful to man; this aspect of science appears in every definition of téchnè from Aristotle to the Stoa. ${ }^{17}$ Grammar, too, must have its usefulness and its aim (télos euchrèston $\left.=f a a^{\prime} i d a\right) .{ }^{18}$ The aim of grammar is to guarantee our speaking correctly according to the rules of our grammar (hellenismós, latinitas, iräb) ${ }^{19}$ its usefulness is to be found in the fact that through grammar we are able to read correctly and to understand old and venerable writings that would be otherwise incomprehensible to us (e.g. the poems of Homer, or the Qur'ān). ${ }^{20}$

Often philosophical terms and doctrines are used in order to "clarify the discussion'; we will quote a few examples from Zağğāğī’s Iḍăh, namely from the discussion concerning the priority of the masdar. This controversy between the Bașrians and the Küfans has been dealt with

14 Translation Dunlop, 1951, 83, cf also Zağḡäğì's analysıs of the definition of 'man', Id 46, 7-11

15 For instance in Mubarrad's definition of the noun the intention to define the noun in terms of 'subjectivity' (taqrib 'alā '/-mubtada'), Zağg Id $51,5$.

16 SVF 2, 226, cf van Ess, 1970, 37 sqq and note 90, van den Bergh, 1954, 2, 84 , 129.

17 Zağğ. Id. 95-6, Steınthal, 1891 2 , 163-5, cf. scholıa D.T 108, 31-3 'An art (téchnè) is a systematic collection of observations that are acquired by cxperience, it serves a useful and vital end' [G 39], (a Stoic definıtion, cf. Zenon. SVF 1, 21), cf Far. ap Dunlop, 1951, 84-5 'We say that an art is a faculty found in the soul, such that it produces organization in a subject towards a particular aim' In Arabic literature this is the fourth of the 'four scientific questions', Rescher, 1966, 40. Dunlop, 1951, 79 (Fārābīs introduction to Porphyrios' Elsagôgì)

18 Steinthal, $1891^{2}$. 2, 179-80; 188-9; fä'ula of chapter II

19 'Aim' and 'usefulness' amount, of course, almost to the same thing. For the 'alm of grammar' Dion Thr pp. 5-6 (enumeration of the parts of grammar), and ef scholia D T 2, 22, 109, 37-8; 446, 6; Proklos. scholia in Crat 12, $13-6$

${ }^{20} \mathrm{Cr}$ the claim of the grammarian against Sextus Empırıcus that grammar is useful, because only through grammar can we discuss what the poets really meant, Sext. Emp adv math I, 270 sqq. 
above in so far as it contains Greek grammatical elements. ${ }^{21}$ The Bașrians claimed that the masdar was prior to the verb, and some of them adduced proofs borrowed from logic. For instance, in order to prove that the masdar is prior to the verb because it is the verbal noun, they say that the agent precedes his action, and that he must know the action before he can perform it. ${ }^{22} \mathrm{We}$ may point to the Mu'tazilite answer to an objection to their doctrine that Allāh has eternal knowledge: to meet the objection that, Allāh's knowledge being eternal, the object of that knowledge must be eternal, too, the Mu'tazilites introduce the distinction between possibility and actualization of an action. Allāh's knowing an action implies the possibility of that action, not the actual happening of it. In the same way, someone who is eating must necessarily have been before in the state of knowing the action of eating; otherwise he could never have started to perform the action of eating. ${ }^{23}$

In the same discussion it is argued by the Bașrians that the sounds of the masdar are found in all verbal forms, which implies that the verbal forms are derived from the masdar, and not the other way round. Zağğăğì then quotes the ahl an-nazar, i.e. those scholars who use dialectic methods. ${ }^{24}$ They compare the relation between masdar and verbal forms to the relation between a metal and the objects made from that metal: the 'idea' (ma'nā) of silver is found in a silver ring, but the 'idea' of a ring is not found in silver.

The example of the metal (silver) and the ring formed from it is traditional; there are other instances, where it is used for explaining the production of something out of nothing. ${ }^{25}$ Zağgāăğ example

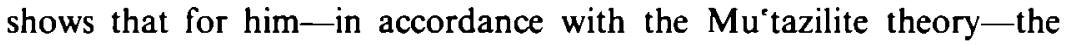
potentiality of change is not located in the changing object, but in the causa efficiens, i.e., in the last resort, Allāh, whether as the prime and only Creator, or as the Creator of the causae secundae. This

21 Cf above, chapter III C

22 Zağğ Id 56, $14-57,3 ; 73,15-9$; cf the discussıon concerning the priority of the masdar, chapter III C

${ }^{23} \mathrm{Cr}$. Abū'l-Husain al-Hayyāt (d after 912/300), Kıtāh al-mısār w'a-'r-radd alā ıbn ar-Räwandi al-mulhid, ed transl Nader, Beyrouth, 1957, 81, 17 -82, 1, of Nader, 1956, 68-9.

24 Zağğ Id $59,13-60,2$

25 Van den Bergh, 1954, 2, 62, n 841 : the production of a ring from the original silver implies the appearance of a new accident and cannot be the result of an inherent principle, cf. Frank, 1966, 21 sqq. A different instance, in Gurḡānī, is quoted by Heinrichs, 1969, 75. 
view differs fundamentally from the view of the ashā $b$ al-hayūlă, who believe that the objects already contain the idea of their future shape. and that in everything there is an inherent principle of potential change-which is more in line with Greek philosophy. Sextus Empiricus, for instance, used the example of bronze and a statue made from it in order to explain the susceptibility of certain materials to become certain products. ${ }^{26}$

As an example of the 'logical' turn a grammatical discussion may take, we will analyse now another passage from Zağğāğı̀s discussion of the thesis that the masdar comes before the verb, because it is a verbal noun, and has, therefore, priority. This thesis is refuted by an adversary with arguments borrowed from logic and philosophy. ${ }^{27}$ The line this reasoning takes is rather complex and it includes a variety of arguments, so that the connection is vague and sometimes nearly incomprehensible. We will deal with the various elements point by point. The adversary says: 'We do not say that nouns are prior to verbs in an absolute sense, but we say that the noun is prior to the verb of which it is the agent. Now, in this chapter we have already reached an agreement on the fact that "noun" has the technical meaning of "nominatum" because it takes its place when something is predicated about it. We say therefore that Zaid precedes the verb of which he is the agent, but it does not follow from this that he has precedence over a verb of which someone else is the agent. If this is true, then a masdar does not necessarily have precedence only because it is the verbal noun. Nor do we assert in an absolute sense that a noun has precedence over its nominatum, and that it never exists after it: on the contrary, noun and nominatum must needs exist side by side during the time of their existence. With "noun" we indicate the meaning of its rights to "nounness". Doyou not see that you can call a given person during his lifetime "Zaid", then you can take this name away from him and call him "Bakr", and after that you can take that name away from him and call him "'Umar"? But his right to "nounness", you cannot take away: the two of them (sc. nominatum and nounness) always coexist. Do you not see that something befalls it (sc. the nominatum), something which does not leave it, something which it possesses in each and every circumstance? That is the reason why people make the mistake of thinking that a noun is identical

\footnotetext{
26 Sext. Emp. adv math 1, 108; cf. Sophr. 2, 410, $36-411,2$.

27 For the grammatical arguments, cf. above, chapter III C
} 
with its nominatum. There are some people who call something that does not exist a thing, others deny this. ... As it is now certain that the noun has no precedence over the nominatum, your argumentation that the masdar has precedence over the verb, because it is its noun, and that it therefore comes necessarily before the verb, has lost its validity'. ${ }^{28}$

1. In the first place, the anonymous adversary states that one cannot make the generalization that nouns come before verbs. One could say that a noun comes before its own verb, just as an agent comes before his own action, though not before the action of someone else. In this context 'noun' is used in the sense of 'the person who performs the real action'. ${ }^{29}$ When we know that the person Zaid comes before his own action, and not necessarily before the action of someone else, we also know that the noun zaid comes only before its own verb, and not necessarily before another one. Hence it follows that we cannot use the argument of the priority of the nouns in order to defend the priority of the masdar on the ground of its being ism li-fi $i l$ (verbal noun). ${ }^{30}$

2. Even if we cannot use the thesis of an absolute priority of nouns above verbs, there is still another possibility: if we could prove that an ism (in this context 'a name', 'a word') precedes its musammā (the object denoted by the word, in this case the verb: the masdar is the ism al-fi $i^{\circ}$, therefore, the $f^{\circ} l$ is named by the masdar, and is its musammā), we could show that the masdar is prior to the verb. This turns out, however, to be as fruitless an argument as the first one, because it is impossible to accept anything but the coexistence of the asmā and the musammayāt: it is inevitable that they exist at the same time. ${ }^{31}$

${ }^{28}$ Zağg. Id 57, 4 - 58, 5 [A 68], in lıne 11 read at-tasmuya for $/ 1$-ısmivya

29 Usıng ism with the sense of musammä is permitted in the thhär, i e when you are talkıng about nouns and explanning their relations with verbs, cf. chapter VIII, note 75

30 The use of the term ism $\mid i-f i l(57,8)$ instead of the usual ism al-fil (e.g 56, 3)- ${ }_{1} \mathrm{f}$ it is not a mere printing error-could be an indication of the fact that the speaker, who is defendıng the Küfan theory, is aware of Küfan termınology, which uses $t \mathrm{sm} a l-f \bar{l} /$ in another sense, namely with the meaning of 'interjection' (c饣. Mahzzūmi, 1958,308 ), and that in this way he tries to avold ambiguity. The opposite procedure is

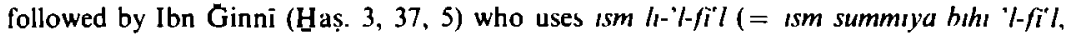
ib $3,36,13)$ to indicate those words which are called by the Kūfans $t s m$ al-f $\vec{i} l$.

31 Van Ess, 1970, 45. According to Storc theory a sign can only be a sign of somethıng it coexists with (sèmeion parón paróntos) (SVF 2, 73, 24) Cr. Steinthal, $1890^{2}, 1,308-9$. 'Da das Zeıchen uberhaupt nur ein Gedankenwesen (noètón) ıst-denn 
3. That ism and musamma indeed always coexist is confirmed by the definition of the notion ism, which means nothing more than the right of a certain thing to being named, to nounness (independently of the concrete name it receives, or of a change of name ${ }^{32}$ ). Every thing (say') has this right and it cannot lose it, because it is an essential part of its being (mauğùd bi-unḡūdihi).

4. The notion say' is then elaborated within the framework of the Stoic categories. ${ }^{33}$

5. Ism and musammä being so closely connected, some people believed them to be identical; this al-ism huwa '/-musammä-theory will be dealt with in the chapter about the Mutazila. ${ }^{34}$

6. It would be possible to object against points 2 and 3 (ism and musammā always coexist) that there are some non-existing things which despite their non-existence are nevertheless called $a \check{s} y \vec{a}$. In that case, the ism would precede its, as yet non-existent, musammā, and it would no longer be mauğüd bi-wuğüdihi. This argument may be refuted when we prove that the so-called non-existing things

nicht als Tatsache ist es Zeıchen, sondern nur als eln im Gedanken bezogenes - so ist auch nicht die Tatsache als solche, sondern nur das auf das Zeichen gegrundete Urteil zu beachten, und dieses ist eın Gegenwärtıges'. The same conditıon is mentıoned in the definition of "illa by Ibn al-Anbāri (Lum 54, 9-10) This is consıstent with the opinion that words are signs of the things (sımät), and that these signs are conventional. Cf the following note and below, chapter IX The relation between illa and ma'tül is also explaıned by al-Gubbā'i, ap Ašarī, Maq 390 and by 'Abd al-Gabbār, Mugni, 4, 313; cf Frank, 1967, 251.

32 This reminds us of Plato, Crat $384 \mathrm{D}$. It seems to me that whatever name one gives to somebody, that will be his right name, and if you then give him another name and call him no longer by the first one, then, the second name will be no less true than the lirst one' (Hermogenes is speaking) [G40]; cr. Amm. comment. in Aristot. de interpret. 20, 18 (hè tôn onomátôn metáthesis) The opposite opinıon is found in those theological writings which defend the divine creation of the names, e.g in Proklos (cf Daniélou, 1956, 426): everythıng has its proper name given to it by God, the same is asserted in the Arabic world, e.g. by Gābır ibn Hayyān (cৎ Kraus, 1942, 2, 257-8) For the influence of the Cratylus on Arabic theories concerning the origin of speech, cf below, chapter IX.

${ }^{33}$ Rescher, 1966, 69-70, (šay'); 70 (mauğüd); 80 (häl) Accordıng to Rescher, one could say about the notion $h \hat{a} l$ that the circumstantial evidence points almost conclusively to a Stotc origin'. (l.c. 80, n 37). On häl also: van den Bergh, 1954, 2, 4 Śay' is defined by the theologians and the philosophers as "that about which something can be said, and which can be designated' ( $m a \bar{a}$ yağüzu an yuhbara 'anhu wa-yasihhu 'd-daläla 'alaıhı) (cI Hwār. Maf. 22, 14; Ašarı, Maq. 161, 9-10; van den Bergh, 1954, 2, 4; 122). According to Rescher and van den Bergh the notion say' is based on the Stoic $t$, cf below note 35 .

$34 \mathrm{Cr}$. chapter VIII. 
in reality do exist. ${ }^{35}$ This proof is provided by a quotation from the Qur'ān, ${ }^{36}$ and by a fictitious example.

7. After the excursion about the non-existent things we are brought back to the main argument. The adversary concludes that the

35 Van den Bergh, 1954, 2, 62, n. 85.2. According to Stoic theory the highest genus of everything, corporeal or non-corporeal, existing or non-existent, is the $"$ (something) (cf. Rescher, 1966, 66-80; the quotations on page 78 , note 31 , from SVF are irrelevant, since they do not prove that the Storcs held anything like the aforementioned theory: we could refer to SVF 2,117, 28-33 = Seneca, ep. 58, 15): The first genus seemed to some Storcs to be the 'something', why this seemed so to them. I shall mention presently In the universe, they say, there are things that exist, and things that do not exist. These non-existent things are nevertheless part of the universe as well, namely those things which occur to the mind, like Centaurs and Giants and anything else which, formed falsely by the imagination, starts to have a shape, though not a substance' (Primum genus Stolcis quibusdam videtur 'quid', quare videatur subilciam In rerum, inquiunt, naturae quaedam sunt, quaedam non sunt. Et haec autem, quae non sunt, rerum natura complectitur, quae animo succurrunt, tamquam Cenlaurı, Gigantes et quicquid alıd falso cogıtatıone formatum hahere alıquam ımagınem coepu, quamvis non haheat substantiam); of also Diokles Magnes ap Diog Laert 7, 52 = SVF 2, 87 This theory on non-existent things formed part of the Mutazilıte doctrine (Nader, 1956, 134-5; van Ess, 1966, 191-200, Bernand, 1972, 39-40 'la positıvité du néant'). Accordıng to several Mu'tazilıtes-among them 'Abbād ibn Sulaimān, al-Hayyã (d. after 912/300), al-Gubbā'ì, and $A b \bar{b}$ Hāšim-non-exısting thıngs are already thıngs with theır own essence and attributes. Allāh can only provide them with the attribute of existence-this is the act of creating It would appear that Stoic theory is at the root of this doctrine, rather than Aristotelian hylomorphısm, where existence is preceded by the mere metaphysical possibility of future existence, not by a real essence (cf Nader, 1956, 143-4 for a different opinıon). Rescher does not provide any quotations for this theory outside the immediate reach of philosophy and logic. As we have seen, it could also be used in grammar, though doubtlessly with less profit than in Mu'tazilite theology

${ }^{36}$ Qur'àn, 24/39: '.. like a mirage in the plain, the thırsty man thinks that it is water, but when he comes to it, he does nol find a thing' [A 69]. The example is traditional Rāzi (Maf. 14, 7-8) mentions the dıfficultıes raısed by Muḡāhıd ıbn Gabr, a famous commentator on the Qur'ān (d 722/104); cf Sezgın, 1967, 1, 29 Muḡahid found in this verse a contradiction between 'tıll he reaches it', which implies that it is something, and 'he linds out that it is nothing'. One proposal for a solution is to take $\overline{l a} \check{s}_{a} y^{\prime}$ in the sense of $\overline{l a} \check{s} a y^{\prime} n \bar{a} f \bar{t}$ (nothing useful), or to translate 'till he reaches the place of the clouds, and finds out that those clouds are nothing' Zağgăă mentions this solution, and another one according to which mirages are actually sunrays that glitter on the sand (Id 57, 17-21). Another Qur'ānic example is mentioned by Rāzì, Maf. 2, 94, 6-10. For Zağgāgīs second example-that of a man we seem to recognize when we look at him from afar, but on approaching he tums out to be someone else-we refer to Suyūṭi (Muzh. 27, $19-28,1)$ and to Rāzi (Maf. 1, 23, 21-4) where almost the same example is used, but another conclusion drawn from it, namely that meanings correlate with something in the mind, not with something in the outer world: when we imagine that we see someone we know, but on approaching him we have to change our opınion because he turns out to be someone else, the difference of the names which we have given to the object perceived by us does not prove that something non-existent was given a name, but it does prove, according to these authors, that names correlate with pictures in our mind (suwar dihnıyya), not with objects outside us. 
argument about the precedence of the asmä' over their musammayāt has been invalidated, so that there is no way to prove the precedence of the masdar over the verb by means of this argument.

Zağğăğìs answer is that we are not discussing the possibility of proving the priority of either asmä' or musammayāt in a semantic theory (or rather: an epistemological theory), but in terms of grammatical facts. The proof of the priority of the masdar is, therefore, reduced to the proof of the priority of the noun, grammatically speaking. Ism al-fil must be taken, not in the sense of ism vs. musammā, but of 'grammatical noun vs. grammatical verb'. There is a consensus that nouns are superior to verbs. ${ }^{37}$

There is another interesting remark: ${ }^{\mathbf{3 8}}$ according to Zağğāği the theory of the adversary does not even prove that asmä' and musammayāt are coexistent. Zağğāğì does not explain in which way one could refute this argument of the adversary, because his intentions are only grammatical. But there is a chance that he means the theory that there are maiani without an ism-which would prove the posteriority of the $a s m \bar{a}^{3}{ }^{39}$

We are left with the question of the identity of the adversary. We have already demonstrated in our introduction that logico-grammatical discussions like the one under discussion here are characteristic of the grammarians in Baghdad during the fourth century. They tried to defend the old theories of the two schools with new logical arguments. In our passage we encounter a very fine example: the adversary defends the Küfan theory, but we cannot possibly consider him as a real 'Küfan'. ${ }^{40}$ Perhaps he was Ibn Kaisān, one of the teachers of Zağğāğì, who constantly switched between the two schools and often taught and defended Küfan theories. ${ }^{41}$ That he indeed held the Küfan theory on this point of grammar is shown by his words in the commentary on Ibn as-Sikkit's Tahdib al-lugia: 'The masdar which belongs to $a^{\text {ee }}$ altu is $t a f^{2} i l$; $f i^{i e} a \bar{l}$ also occurs, analogous to the expres-

1 Cl Zağğ Id, ch XI, pp 83-4

It Ib $58,6-8$

39 Ràzì, Maf 1, 24. 2-4. 'It is impossible for all substances to be named by expressions, because the substances are infinite What is infinite cannot be determined by analysis, and what cannot be determined by analysis is prevented from receiving a name' [A 70] Cf Suy, Muzh. 1, 26 pen. - 27, 2 'Can every ma'nä have its lafz?' On the infinity of things, of below, chapter VIII, note 73 .

40 But of above. note 29

41 Or Ibn Kaıān, cl above, chapter VI, note 66 
sion dahrağtuhu dihrāğan (I rolled it down), because fa"ala and fa'lala have the same pattern with regard to vowels and vowelless consonants, and their masdars are formed in the same way, because of the resemblance in pattern'. ${ }^{42}$ These words presuppose the dependency of the masdar on the verb, in so far as the masdar is said to be formed from the pattern of the verb, i.e., is said to be secondary to the verb.

Philosophical terms are also used in support of the thesis that some parts of speech are prior to other parts. We must, says Zağğāği distinguish between various meanings of the term 'prior'. ${ }^{43} \mathrm{He}$ then gives the example of a body and its colour: colour is an accident and ipso facto posterior to the body in which it inheres, because the elimination of the accidents does not eliminate the body itself. ${ }^{44}$ Accidents can only exist in a body; thus, colour only has existence in a body, ${ }^{45}$ although it may be thought of as being independent of the body. ${ }^{46}$ On the other hand, there does not exist a body without colour. Nevertheless, we can say that bodies are prior to their accidents, and in the same sense we can also say that, for instance, nouns are prior to verbs. They always coexist, yet the agent is always prior to his action. ${ }^{47}$ Another example is the coexistence of the male and the female principle, ${ }^{48}$ which does not prevent us from saying that the male principle is prior.

After the writings of Aristotle had been translated, his definitions of noun and verb became commonplace in philosophical literature. ${ }^{49}$ Apparently there were also grammarians who felt themselves attracted

42 b Sikk Tahd. $566 \mathrm{c}$ [A 71]

42 Compare with this the discussions in Greck logical literature concerning the varıous meanıngs of próteros Aristot categ 14 a $26-14$ b 23, Joh Dam, chaplers $7,13,60$

${ }^{44}$ Cf e.g Joh Dam , chapter 7, 2-3 = 13, 2-3, and below, note 88

${ }^{45} \mathrm{Cr}$ e.g Joh Dam 43, 19-21, 52, 77-81, colour is in a body, and not the other way round, ib 4, 24-6; Aristol categ 1 d 28 'cvery colour is in a body' (hápan gàr (hrôma ('n sômatı)

46 Van den Bergh, 1954, 2, 107; Bernand, 1972, 34, 1973, 51-2; As̆arī, Maq 392.

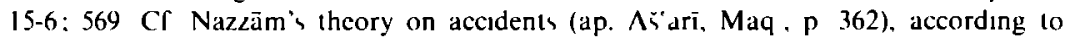
which we cannot perceive anything except the colours, which are the bodies, no body is without a colour According to the Mutdilites, substances and accidents were Inseparably linked, cf Nader, 1956, 158-60

$47 \mathrm{Cf}$ above, note 22

48 Except in the case of the Qur'anic account of the creation of Eve after Adam This is the sort of reasoning we also find in the argument about the creation of speech allowance is made for the Quranic account. but then, lingustic theory is developed Independently, cf below. chapter IX

${ }^{44}$ On Aristotle's definitions' Steınthal, $1890^{2}, 1,238-44,261-2$; Larkın. 1971, 28-33 
to these definitions, at least that is what transpires from Zağğāğìs remark quoted at the heading of this chapter about the Aristotelian definition. Zağğăği himself tried to keep logic and grammar apart, but did not always succeed.

Aristotle defines the noun in the Poetica: 'A noun is a composite meaningful sound without time, no part of which is meaningful in itself, ${ }^{50}$ and in the De Interpretatione: 'A noun is a conventional, meaningful sound without time, no part of which is meaningful when it is separated'. ${ }^{51}$ The difference between the two definitions is explained by the different nature of the two texts: the Poetica deals with the various elements of speech, from the smallest (stoicheia) to the largest (logos); one of the relevant properties of the nouns in this context is that nouns are composed of smaller elements, hence the attribute 'composite'. ${ }^{2}$ The De Interpretatione on the other hand, emphasizes the fact that both nouns and verbs are part of a larger whole, the sentence (lógos), so that their being composite is not relevant. The Poetica does not deal with the nature of words and speech, but rather with the nature of style and literature; speech is treated here as léxis, i.e., as speech from a stylistic point of view. In this context it is not relevant that nouns are the product of a convention. The De Interpretatione, however, is concerned with the logical structure of thought, which is influenced by the conventional nature of speech, hence the statement that nouns are conventional (katà sunthèkèn). Both definitions have in common that the noun is defined as a meaningful sound, whose parts do not have an independent meaning. These two characteristics are shared by the verb, the difference between the two being that nouns do not indicate time, whereas verbs do.

The definition from the Poetica is found in Mattā ibn Yūnus' translation; ${ }^{53}$ the definition from the De Interpretatione is found in al-Fārāb̄̄’s translation and commentary, ${ }^{54}$ as well as in Gazzālīs

50 Aristol poet 1457 a 11-2 [G41]. on the linguistic chapter of the Poefica. Pagharo, 1956, Scarpat, 1950, Morpurgo-Taglıabue, 1967

51 Aristot de interpret 16 a $19-20$ [G 42]

52 We agree with Stemthal $\left(1890^{2}, 1,253\right)$ that Grafenhan's correction of sumhete' (Intelligible) into sumthets (composite) should be accepted. because the original form does not make sense As an additıonal argument may be mentioned Ibn Ruśds translation (Sir. 31, 10) which presupposes a Greek sumtheté. cf Fischer, 1964. 143-4 note

53 Badawi, 1953, 127, 12-3 [A 72]

54 Fārābi, Sarh. 29, l-2 [A 73] 
$M i^{e} y \bar{a} r{ }^{55}$ Gazzāli adds that this definition is 'according to the logicians' ('alä sart al-mantiqiyyin). An abbreviated form of it is given by Hwārizmī, ${ }^{56}$ and by Ibn Rušd in his translation. ${ }^{57}$ A still shorter form is found in Fārābī's Kitāb al-alfäz al-musta'mala fì 'l-mantiq, which leaves out the entire second part of the definition, so that only the difference between the nouns and the verbs remains, not those properties they have in common. ${ }^{58}$

There are also a few additions in the Arabic translations of Aristotle's definitions. Fārābì, Ibn Rušd, Hwwārizmī, and Gazzālī ${ }^{59}$ add that nouns are single (mufrad) words. This marks the difference between them and phrases, which consist of more than one word, a difference which is also found in Aristotle's Categoriae: 'Some expressions are uttered with a combination of words, other expressions without such a combination. The composite expressions : for instance "man runs", "man conquers"; the single expressions: for instance "man", "cow", "runs", "conquers"”. ${ }^{60}$ Besides, Gazzālì says that nouns are 'definite' (muhașsal) ${ }^{61}$ perhaps a reminiscence of Aristotle's distinction between definite and indefinite (aórista) words. ${ }^{62}$

Zağğăğì's version of the definition - 'a noun is an invented sound with a conventional meaning, not connected with time' ${ }^{63}$-is clearly based on the definition from the De Interpretatione, because he mentions the fact that nouns are conventional (bi-'ttifäq).${ }^{64} \mathrm{We}$ must keep in mind that the De Interpretatione was already translated at an early time by Ishāa ibn Hunain, whereas the Poetica was translated only later by Mattā ibn Yūnus. ${ }^{65}$ The meaning of Zağğāăì's additional remark that words are invented (maudü') is explained by Gazzālī's discussion about the invention (wadl) of names by parents for their

is Gazz Mìyār, 41, 11-2, almost identıcal with Ibn Sinnā's definition. 'Ibāra, 7, 45 [A 74]

s6 Hwār Maf 145, 9-10 [A 75]

s7 b Ruid, Sir, 236, 5-6 [A 76]

"F Far Alr 41, 13-4 [A 77]

59 In another versıon of the definitıon, Mìyār, 42, 15-7

60 Aristot categ I a 16-9 [G 43]

${ }^{61} \mathrm{Cf}$ Gazz, Mı̀yār, 42, 15-7

62 Aristot de interprel 16 a 29-30 "The expression "not-man" is not d noun. there does not even exist a name to denote il-for it is neither a sentence nor d negative judgment-, but let us call it an indefinitc noun' [G44] Ónomo aóriston is translated by Fārābì (Sarh. 32, 3) ds ism gair muhasıal

${ }^{63}$ Zağğ Id 48, 10-1 [A 78]

64 The normal translation of katà sumthèken is bi-tanätu', cf Loucel, 1963, 254-5 (23-4)

65 Badaw1, 1968, 76, 78 
children. ${ }^{66}$ The Arabic term wad", just like its Greek parallel thésis indicates the human creation of a name. ${ }^{67}$ This is in accordance with the conventional nature of the nouns, as held by Aristotle and by the Arabic logicians as his successors.

Zağğàği mentions another variant of the Aristotelian definition of the noun-a noun is an invented sound with a conventional meaning without time, whose parts do not participate in its meaning ${ }^{\mathbf{6 8}}$ _, which includes its second part (the constituent elements of a noun do not possess an independent meaning). We may compare with this the two versions of the same definition given by Fārābi in his commentary and in the Kitāb al-alfār. On the whole, we believe that Fārābì was Zağğăğì's primary source for the logical definitions, probably through Ibn as-Sarrāğ, his pupil and Zağğāḡì's teacher. ${ }^{69}$

There is still another version of the logical definition in grammatical literature, namely the one mentioned by Sïrāfi ${ }^{70}$ and Ibn al-Anbārī. ${ }^{71}$ This version is characterized by the term iqtiran (combination, sc. with time). ${ }^{72}$ Another group of definitions stress the fact that nouns do not denote time, thus setting the nouns apart from the verbs, for instance Zağğàğ's definition. ${ }^{73}$ These are related to Fārābī's second variant in the Kitāb al-alfäz.

Arabic grammarians usually define the verb morphologically, i.e. they list those of its morphological properties that mark it as different from the noun and the particle. ${ }^{74}$ Sometimes, they give a syntactic definition, which emphasizes the function of the verb as predicate of a sentence, itself unable to receive a predicate. ${ }^{75}$ In the De Interpretatione Aristotle defines the verb as follows: 'A verb is (a word) which also indicates time (prossemainei); none of its parts has a signification of its own. It is the sign of things which are predicated about some-

66 Gazz. Asmā', 6, 11-4.

${ }^{67}$ E.g scholia D.T. 130, 16 titherar kata as compared with the Arabıc u'udia 'alä; cf. below, chapler IX, note 61

os Zağğ Iḍ 49, 6-7 [A 79]

${ }^{69} \mathrm{Cf}$. above, chapter VI, note 57 .

70 Sır. Sarh al-Kıtāb, 1, 7 [A 80], quoted by Mubārak, in his edıtıon of the Iḍah, p 49. note 1 . Almost the same definition is ascribed to Ibn as-Sarrāg by al-'Ukbarī, Mas. 44 , $1-2$, but this is probably an error on his part (cf. the editor's remark in his introduction to the edition, pp. 18-9)

71 b Anb. Asr. 5, 18-9 [A 81].

72 Cf Zam. Muf 4, 19-20, also quoted by Rāzī, Maf. 1, 34, 24-5 [A 82].

${ }^{73}$ Zağğāğ ap. b. Fār. Sāh 51, 2-3; cf. Rāzì, Maf 1, 35, 9-10.

${ }^{74} \mathrm{Cr}$. above, chapter III, $\mathrm{B}$.

$75 \mathrm{Cr}$. above, chapter III, B 
thing else'. ${ }^{76}$ In the Poetica the predicative function of the verb is not mentioned: 'A verb is a composite, meaningful sound with time, no part of which is meaningful in itself. ${ }^{77}$ We should not regard 'time' in this context as a morphological property, but as a property of the meaning signified by the verb. In the translations of the De Interpretatione definition by $\underline{H}$ wãrizmi and Fārābī, the term prossèmainei has been divided into two parts: the verb signifies some meaning (dalla ala mainan) and it also signifies the time of that meaning

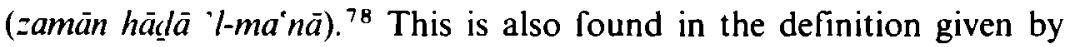
Gazzālī, who adds that the verb does not signify time in general, but the time of the meaning signified by it (this marks the difference between verb and temporal adverb). ${ }^{79}$ In Zağğăğì's definition-'the verb is what signifies an event and a past or future time'so -we find the influence of the Aristotelian definition, though with a significant change: the term 'meaning' has been replaced by 'action' (hadat). The verb is now described as a word which signifies action and the time of that action. Perhaps this change was a reference to Sibawaihi, who wrote that verbs are the expression of 'the actions of the nouns' (ahdāt al-asmā'). ${ }^{81}$ This is also the case in the definitions given by Zamahšsarī and by Rāzī. ${ }^{82}$

In Greek grammar the situation is as follows: Dionysios Thrax defines the verb according to its morphological properties: 'The verb is an undeclined word which can receive tenses, persons, and numbers, and which expresses an action (enérgeia) or a passion (páthos)' ${ }^{83}$ This definition has been imitated by other authors, including Apollonios Dyskolos. Apollonios adds, however, that morphological properties are not essential for the verb: the most characteristic feature of the verb is that it signifies an action (prâgma). Only thus can we include

76 Aristot de interpret 16 b 6-7 [G 45]

7 Aristot poet. 1457 a 145 [G 46]

78 Hwār Maf 145, 12-3 [A 83]; Far Sarh, 33, 1-3 [A 84], cf. also Far Alr 41, 15 42, 1, the Poetica-definition is Iranslated by Mattā ibn Yūnus, Badawī, 1953, 128, 3-6 [A 85]; cr. lbn Ruǐd, Sirr, 236, 9-11 [A 86]

${ }^{79}$ Gazz Mìyār, 42, $17-43,1$ : 'The verb $(k a l ı m a)$ is a single expression whıch signifies a meaning, and the time in which that meaning exists '[A 87]

Bo Zağğ Iḍ. 52 ult [A 88].

a Cf. above, chapter III A

y2 Zam. Mur. 108,6. "The verb is what signifies the combination of an action with tıme ...' [A 89], quoted by Rāzi, Maf. 1, 36, 11, cf. also Rāzì, Maf 1, 36, line 9 from below. 'The verb is a word which signifies the inhering of a masdar in an indefinite thing during a definite tıme' [A 90]

${ }^{83}$ Dion. Thr 46, 45 [G 47]. 
the infinitive in our definition of the verb The rest of the properties is accidental (sumparhepomena) ${ }^{84}$ Probably, this emphasis on the prâgma as essential meaning of the verb in later Greek grammar IS responsible for the replacement of maina by hadat in the Arabic definitions of the verb in grammatical writing It is significant that mánā retained its place in phılosophıcal definitions

Both in Greek and in Arabic grammar the need was felt to make a hierarchical classification of the parts of speech As speech was considered the reflection of rational thought, which in its turn reflects the rational order in the cosmos-this was commonly thought by all grammarians, whether they held phuset or théses, tauquf or strläh-, one could not accept that each part of speech was to occupy the same place in hierarchy, and that it was to have the same rights as the other parts ${ }^{85}$ Apollonios Dyskolos justifies his search for hierarchy with the argument that once one accepts the hierarchical principle for the letters of the alphabet, one cannot agree with those who assume that the order of grammatical elements is determined entirely by accident ${ }^{86}$ This demonstrates the necessity for a grammarian to make rules for every part of grammar, and to explain every linguistıc phenomenon In this respect Greek and Arabıc grammar resembled each other very much

When we analyse Apollonıos' arguments for the priority of the noun, before the verb and the other parts of speech, together with the arguments found in the scholia on Dionysios Thrax and in other grammatical works, ${ }^{87}$ we find that nouns are prior to verbs because

1 nouns denote substances (ousia), verbs accidents (sumbebèkós), substance is prior to accident ${ }^{88}$

64 Steinthd, $1891^{2}, 2,267$ sqq

8s Apoll Dysk synt pp 15-6

s6 The word martaha indicates the place d word occupies within the hierarchical system of Arabic grammar, originally it means 'step', 'rank', degree', It may also indicate the elevation that serves ds a sedt In 'Abbàsıd society mariaba (or rutba) means the place one occupics at d feast A strict order was observed ds to who had the right to occupy which pldce, so that martaba became the place (manzila) one occupies in the social hierarchy of high society Cr Sadan, 1973

87 In the following texts arguments are given for the priority of the nouns 1 Apoll Dysk synt 18, 5-8, 2 id ib 19, 24 sqq , 3 scholia D T, 71, 5-6, 4 ib 216,8-10, 5 ib $244,5-7,6$ lb 358,11 sqq .7 ib $359,21-3,8$ ib $360,13-4,9$ lb $521,13-20,10$ ib $515,15-8,11$ sb $522,21-33,12$ Choirob $1,105,2$ sqq, 13 id $2,2,22$ sqq, 14 id 2, 3, 6 sqq, 15 Sophr 376, 4 - 377, 8, 16 (Ps)-Theodosios, ed Gottling, p 136, 17 Gregorios of Cormth, $4+7,18$ Amm in Aristot de interpret 102, 34 ed Busse ${ }^{88}$ In texts $9,10,12,13,15$ 
2. nouns indicate the existence of things, verbs the actions and the vicissitudes of those things; the person who acts is always prior to his action. ${ }^{89}$

3. nouns and verbs have the same logical proportion as génos and eidos: if the agent is abolished, the action is abolished as well, while the reverse is not true (sunanhairein ); 90 the action presupposes the agent, while the reverse is not true (suneispherein = sunnoein); ${ }^{91}$ the action is performed by the agent, while the reverse is not true (apotelein). ${ }^{92}$

4. the word for 'noun', onoma, is also used for 'word' in general. ${ }^{93}$

5. noun and verb are the only essential parts of speech, since it is impossible to make a complete sentence without them. In certain cases, however, two nouns suffice to constitute a complete sentence, when the verb 'to be' is understood. A verb without a noun is always incomplete. ${ }^{94}$

From Arabic grammatical literature the following parallel passages may be quoted:

ad 1. For this purely logical argument we have to turn to the logical writings about grammar, e.g. Rāzi: 'The noun is a word that signifies the essence, and the verb is a word that signifies the inhering in this essence of something at a certain time'. ${ }^{95}$ Here the verb is defined as an accident of the essences signified by the nouns. Hebrew grammarians used the same argument. ${ }^{96}$

ad 2. This is the main non-syntactic argument for the priority of the noun in grammatical literature. We find it for instance with Zağğăğí, who also uses it in his chapter on the priority of the

In texts: $1,4,6,8,9,10,12,18$

90 For the meaning of this term: Aristot top. 141 b 28; categ 7 b 38, and cf above, note 42.

91 For these terms: Choirob 2, 3,15.

92 In texts $6,9,13,15$

93 In texts $1,6,11$.

94 In text 17; of Donnet, 1967, 151-3 for further examples. We may compare with this argument a Stoic text, SVF 2,181 ' The Stoics say that some meanings (lektá) are independent, and some are incomplete; incomplete are those meanings that have a disconnected form, e.g. gráphes (writes), because we ask "who?"' [G 48]. Some verbs do not have an expressed subject, namely verbs in the first and the second person, scholia D.T. 57, 12 sqq

95 Rāzi, Maf. 1, 111, 2 sqq [A 91].

96 Cr. Kimhi, Mikhlol, p. 10 (transl.) and note 4. 
masdar $;^{97}$ it is, moreover, the argument that underlies his definition of the noun. ${ }^{98}$

ad 3. The comparison of the relation between noun and verb with the relation between génos and eidos is found, though not explicitly, in the argument of al-Kisā'î, al-Farrā', and Hišăm: 'The noun is lighter than the verb, because the noun is included in the verb, whereas the verb is not included in the noun'. ${ }^{99}$ We may also point to Rāzi's remark: 'It is impossible to use the verb without connecting it with the agent, ..., although we can use the expression for the agent without connecting it with the verb'. ${ }^{100}$

ad 4. Although the term ism is used also for 'word' in general, the argument drawn from this use in Greek grammatical literature is not proposed, as far as we know, by any Arabic grammarian.

ad 5. This argument is very important. Only nouns can form a complete sentence without the help of any other part of speech, but verbs cannot do this. ${ }^{101}$ (The term used to translate the Greek term autoteles in this context is mufid ${ }^{102}$ ). Verbs, even in the first or the second person, always need a subject, which is in Arabic expressed by the suffix; this suffix is equivalent to a noun. ${ }^{103}$ As for the verb in the third person, we never know who is its agent until the noun is mentioned. ${ }^{104}$

\footnotetext{
${ }_{97} \mathrm{Cf}$ above, chapter III C

9* Cf above, chapter III A.

99 Ap Zağğ. Id 101, 3-4; the verb sstatara in this quotation is equivalent to the Greek verb sunetsphérein [A 92].

100 Rāzi, Maf 1, 111, 7-8 [A93], cf. the argument connected with sunanhairein,

${ }^{101}$ Sib Kit 1, 6, 11-2, b. Gın Has 1, 41, 13 sqq, b Anb Inș. 103, 13 sqq ; id Asr p 9, Rāzi, Maf. I, 111, 2 sqq , cf Zağğ. Id 100,3-5, where this argument is used in the discussion about the lightness of the nouns as compared with the heaviness of the verbs, cf Gabučan, 1972, 31

$102 \mathrm{Cr}$ above, chapler II.

$103 \mathrm{Cr}$ e g. b. Gin Has 3, 20, $10 \mathrm{sqq}$ for the verbal forms qumtu and qäma the first form. 'I stood up', contains a pronoun with a phonetic expression, in the second form, 'he stood up', the pronoun is understood and does not have a phonetic expression. Pronouns are included in the category of the nouns, cf above, chapter III A, note 93 The verbal forms in the first person were analysed differently in Greek grammar, cf. above, note 94
} above

${ }^{104} \mathrm{Cr}$ Zağğ Id 100, 3-5 with text 17 (Gregorios) 
There are two additional arguments:

1. Nouns only signify a nominatum, whereas verbs have to signify an agent, one or more objects, the masdar, the time and the place of the action, and the condition of the agent $(h \bar{a} l) .^{105}$ Nouns are, therefore, lighter than verbs, and thus, prior to them. The same fact is mentioned by (Ps.-) Theodosios, but in order to defend the priority of the verb: 'The verb has even something more than the noun. The noun signifies only the thing (sc. the nominatum), but the verb signifies something more, e.g., légo (I say) indicates the action in itself, in this case (the action of saying, but, moreover, it signifies the time .... ${ }^{106}$

2. The Bașrians used still another argument, which was stated in terms of the syntactic ability to serve as the subject and/or the predicate of a sentence. ${ }^{107}$

Subject and nominal predicate, says Zağğăğì, are substances or accidents represented in speech by their names. ${ }^{108}$ But we also define them as those words to which we may apply specifically nominal ideas ( $\left.m a^{\circ} \bar{a} n i\right)$, such as attributes, prohibitions, or vocatives. In other words, subject and predicate (al-muhbar 'anhu wa-'l-muhbbar bihi) are terms which may stand for something in the outer world, or, in metalanguage, for those words which represent them (al-ism an-nä'ib an al-musammāa), and which are characterized by the nominal ideas they may receive (al-ma'ani allati ta tawiruhāa). What is meant by 'nominal ideas'? In order to understand this we must consult the Greek data.

Protagoras the Sophist (5th century B.C.) was the first to speak about classes of sentences: he distinguished between four 'pillars of speech' (puthménes logôn), viz., wish, question, answer, and command. ${ }^{109}$ According to Koller this division was the result of his rhetorical studies, ${ }^{10}$ and actually we find in Aristotle's writings that there is only one sort of sentence that can constitute the subject of logical studies: the simple true-or-false judgment (apóphasis, Aussage). All other sorts of sentences such as command, wish, question, etc.,

109 Ràzí. Maf I. 50. 15-6. Ta"lab. Mağ pp 266-7. Zağğ Id. 101, 1-2.

100 On the notion consigminare Pinborg. 1967. 30 sqq. The quotation is from (Ps -) Theodosios. ed Góttlıng, p. 136. cf. Steinthdl, 1891² 2. 236 [G 49]

${ }^{107} \mathrm{C}$ above, chapter III A, note 82. III B. note 33

104 Zağg Id. 42. 14 squ

109 Cf Radermacher. 1951. p 38. frg. 10

110 Koller. 1958 
belong to the art of rhetoric, ${ }^{111}$ since they cannot be subjected to the test of truth or falseness. ${ }^{112}$ This logical doctrine was then constantly repeated by the commentators, who mostly distinguished between five sorts of speech (judgment, command, wish, question, invocation) ${ }^{113}$ On the other hand, we find that in grammar the Aristotelian classification turned into a genuinely grammatical one, and almost coincided with the division into grammatical moods: the 'wish' became an optative, the 'command' an imperative, and so on. ${ }^{14}$ Apollonios Dyskolos tells us of these moods (enkliseis) that they are 'mental conditions' (psuchikai diathéseis) with regard to the action or with regard to another person. Here we find expressed for the first time that the verbal mood is not only a verbal form, but that it is a verbal form which is connected with the state of mind of the acting subject. ${ }^{115}$ This explains to a large degree why Zağğāği connects the nouns (i.e., the representatives of acting bodies) with the 'nominal meanings/ideas'. The Stoa put the same Aristotelian division to another use, namely a division into ten sorts of speech, or rather, ten sorts of independent meanings' (lektà autotelè). ${ }^{116}$

111 Aristot de interpret 17 a 1 sqq. . Not every (utterance) is categorical, but only when it contains truth or falseness, which is nol contained in every utterance for instance, a prayer is an utterance, but it is neither true nor false. All other (utterances than the categorical) must be left aside. because they belong rather to the study of rhetoric or literary theory, whereas the categorical utterances belong to the present study' [G 50] Cf. Coseriu, 1970, 74-5, 77-8

112 For the definition of the categorical utterance or sentence: cf above, chapter III $\mathrm{C}$

113 Apophanukón, prostakukón, euhıkón, crôtèmaukón, klèıkón, respecuvely, cf Koller. 1958, 23 The number of five classes of sentences is also given by Ammonıos, cf. below, note 118 .

114 Steinthal, $1891^{2}, 2,272-91$ The subjunctive constiluted the main problem in the attempls to transform the Aristolelian division into a grammatical system. The same confusion of enkliscis and classes of sentences was taken over by the Syriac grammarian Jacob of Edessa, of Merx, 1889, 249-50

115 Apoll. Dysk synt. 44, $9-45,3$ (the question is why the infinitive does nol possess person, number, or mood). 'It seems to me, therefore, that those who inquire why the infinitive lacks person, number, mood, act absurdly, since it (sc the infinitive) is not plural, every action being singular Moreover, it does not possess a mental condition (psuchike diathesis), since it has no inflection to indicate the various persons, and only persons, being rational. can proclaim their own condition of mind Thus, even the verb itself does not possess originally person and number. But when it is used about a person, then it must also distinguish between those persons, which are ingular, dual, or plural, besides Consequently, it (sc the infinutive) cannot possess a mental condition, Just as we have sand before [ $G 51]$

116 These ten classes are enumerated by Sextus Empıricus, adv math. 8, $70=$ SVF 2, 187, and by Diogenes Laertıos 7,66 = SVF 2.186, they are the classes of those lckıá which produce an independent meaning (for the lekıón. below, chapter X) 
Retuming to the Arabic world we notice in the first place the influence exercised by the commentaries on Aristotle's writings, for instance in Fārābì and Ibn Sīnā. ${ }^{117}$ Fārābì reproduces almost exactly the five categories of the Peripatos: judgment about truth or falseness (qaul ḡäzim), command (amr), question (lalb), request (tadarru'), invocation (nid $\left.\bar{a}^{\prime}\right)$. That Arabic scholars were still aware of the Greek doctrine, is also proved by a statement of the Ihwān aș-Ṣafà' that according to some people there are six, according to others ten, sorts of sentence: this corresponds to a remark of Ammonios that the Peripatos recognized five, but the Stoa ten, sorts of sentence. We must take into account that Arabic authors usually distinguished between a negative command (nahy), and a positive one (amr). ${ }^{118}$ The Brethren themselves recognized only: judgment, question, command, and prohibition, so that 'wish' and 'invocation' are missing. ${ }^{19}$ These last two categories do figure in Ibn Hazm's list: judgment (habar), wish or prayer (du' $\left.\bar{a}^{\prime}\right)$, question (istifhām), command (amr); Ibn Hazm, however, does not distinguish between a positive and a negative command. ${ }^{120}$ His term for the categories of sentences is 'elements of speech' ('anāşir al-kaläm). ${ }^{121}$

As for Zağǧāğì, his list-command (amr), prohibition (nahy), invocation (nid $\left.\bar{a}^{\prime}\right)$, attribute (na't) - is not intended to be exhaustive. We notice especially the absence of the category 'judgment', but perhaps the 'attribute' ( $a^{2} t=$ sifa?) ${ }^{122}$ should be considered the equivalent of habar-the term habar is indeed used a few lines later in the sense of 'verb', 'verbal predicate'.

That the categories of sentences are called 'meanings/ideas' (ma'āni) which characterize the nouns, could be explained by the Stoic use of

117 Far Sarh, pp 51-2, b Sinnā, 'Ibāra, 31, 8-15 In Syrıac logıc/grammar we find this division into five classes of sentences with Johannes bar Zu'bi (13th/7th century); Merx, 1889, 163

11 Rasāil lhwān as-Sa ã', 3, 119-20, cf. Ammonıos remark. SVF, 2, 189 • .. so that he (sc Aristotle) does nol deal here with every utterance nol with the wish, nor with the command, nor with any other utterance, either from the five according to the Peripatos, or from the ten according to the Stoa, but only with the calegorical' [G 52]

119 Rasā'ıl, 3, 119, pen. categorıcal speech (habar), questıon (isılhbär), command (amr), prohıbituon (nahv)

120 b. Hazm, Ihk I, 265, 9-10.

121 Arnaldez, 1956, 50, n 1, 'Abd al-Gabbār (Mugni, 7, 3, 8) uses the expressıon aqsäm al-kaläm (sorts of speech; in this context it cannot mean 'parts of speech', cl ib 7, 50, 12 agsäm wa-durüb, e g. hahar, amr, nahy) The term brings to mind the Greek eidè toû lógou

$122 \mathrm{Cr}$. above, chapter III A On nat $t$ Diem, 1970, 315. 
the word lektá in this context, and also by comparison with Apollonios Dyskolos' doctrine, inasmuch as the categories of the sentences represent a mental state of the acting subject; a command, a wish, etc., always presuppose an acting and thinking subject. 


\section{THE MU'TAZILA}

'Speech is made by a spedker, for he produces it. while before it did not exist. therefore, il is an action on his part $^{*}$

According to Ibn al-Anbārī, Rummānī wrote about grammar and logic 'in a Mu'tazilite way' ('alà madhab al-mu'tazila), ${ }^{2}$ which seems to imply that there existed some sort of Mutazilite tradition in grammar. There must have been a specifically Mu'tazilite method and style of writing. We would, of course, be wrong in calling every Mu'tazilite grammarian a professional logician. In this respect Fleisch is quite right when he says: 'Dans quelle mesure des grammairiens ont-ils reçu une formation philosophique, ceci n'a pas encore été précisé. D’al-Aḩfaš al-Awsat (m. 830/215), disciple de Sỉbawaihi, as-Suyūṭi (Bugya, p. 158, 1. 7) rapporte qu'il était mu'tazilite ... Mais l'indication n'est pas suffisante pour en faire un philosophe'. ${ }^{3}$ On the other hand, it is more than likely that a grammarian who was at the same time $\mathrm{Mu}$ 'tazilite, tended to write about language from a logical point of view, considering the data about the aforementioned grammarians. We can also refer to the Kūfan grammarian al-Farrā' (d. 822/207), who was a Mutazilite and at the same time was known for his fondness of using logical and philosophical terms in his writings. ${ }^{4}$ Perhaps we can identify this Mu'tazilite method with that of the 'linguistic philosophers' (faläsifat an-nahwiyyin), a name which indicates those scholars who occupied themselves with the difference between logic and grammar. This group of grammarians must have been closely connected with al-Fārābī, who stands out as one of the principal sources for the knowledge of Greek logic among the Arabs. ${ }^{5}$

1 Zağğ Id 43, 10-1 [A 94]

2 b Anb Nuzhd, 189, 10-1, according to Nyberg (EI², 790-1, s v Mu'tazila) the Mu'tazilites introduced the strictly grammatical method, he also notes the very close connection between them and the philological school of Basra

3 Fleısch, 1961, 25, n I

4 Suy Bugya, 2, 333 sqq

5 Cr above, chapter VII, note 6 That these Mu'tazılite grammarians may be treated as a group is also confirmed by the fact that there existed a special biography of the 
As for the number of grammarians who belonged to the Mu'tazila, it must have been considerable. The following grammarians are said to have held Mu'tazilite views: Abū 'Amr ibn al-'Alā' (d. 770/154); ${ }^{6}$ 'Isā ibn 'Umar (d. 766/149); ${ }^{7}$ al-Halíl (d. 791/175); ${ }^{8}$ Sỉbawaihi (d. 793/177); ${ }^{9}$ al-Aḩfaš al-Awsaț (d. 830/215); ${ }^{10}$ al-Farrā' (d. 822/207); ${ }^{11}$ Quțrub (d. 821/206); ${ }^{12}$ al-Māzinī (d. 863/249); ${ }^{13}$ al-Mubarrad (d. 898/285); ${ }^{14}$ al-Fārisī (d. 987/377); ${ }^{15}$ Ibn Ginnī (d. 1002/392) $;^{16}$ asSìrāfi (d. 979/368); ${ }^{17}$ ar-Rummānī (d. 994/384). ${ }^{18}$ Doubtlessly, Zağğāği also belonged to the Mu'tazilite grammarians, as may be inferred from the Idahh. ${ }^{19}$ Even if we allow for a certain unreliability of our sources, especially about the earlier grammarians, there still remains a respectable number of names mentioned in connection with the Mu'tazila.

We shall see in chapter IX that the Mu'tazila played an important part in the development of the theories about origin and nature of speech. Their preoccupation with this and similar subjects is partly due to their main dogma, the creation of the Qur'ān, partly the result of their interest in logic. We may say that this interest in logic led them to study the differences and the similarities between the two disciplines of logic and grammar-a very popular topic in the discussions of the 9 th/3rd and the 10th/4th century, as we have seen above. Thanks to the Mu'tazila or to the Mutazilite grammarians, grammar became more preoccupied with the rationalization of gram-

nuhāt al-muitazlla-this is mentıoned by Suyūti, Bugya, 1, 527, 18, in the biography of a certaın Abū 'l-Ḥasan al-Būrānī an-Nahwī, ê Mubārak, 1963, 24l, n As to the connections between the Mu'tazila and Ma'mūn's Baut al-hıkma. Eche, 1967, 48-54, on Ma'mūn's relıgıous polıcy · Sourdel, 1962.

6 Zağğ Mağ. 80, 9.

7 b. Murt. Tab. 131

8 Id. ib.

9 Id. ib.

${ }^{10}$ Id. ıb.; 'Abd al-Gabbār, Mugnī, 7, 218, 7, Suy. Bugya, 1, 590-1

1 Suy. Bugya, 2, 333, 7.

12 b. Murt. Tab. 131, b. Gin. Has 3, 255, 7 sqq : Abd al-Gabbār, Mug̀nī, 7, 218, 7

13 Zağg. Mağ. 294, 5-6 97; cf. 'Ubaidī, 1967, 60-7, especially p 66

14 b. Murt. Țab. 131; 'Abd al-Gabbār, Muginnī, 7, $218,7$.

15 Suy. Bugya, 1, 496; id Muzh. 1, 7, 10-1; b. Murt. Tab 131.

10 b Murt Tab, 131; Suy Muzh 1, 7, 10-1; id Ašbāh, 1, 338; cf Nağğār in his introduction to the $\underline{H} a a_{a}{ }^{i} i s$, pp $42-3$, for further reference

17 b. Anb. Nuzha, 184, 15, b. Murt. Tab 131.

18 b Anb. Nuzha, 189, 11; cf above, chapter VI, note 11.

19 This may be inferred from his words that speech is an act of the speaker and not created by Allāh (cf Iḍ. 43, 16-7) and from his opınıon about the ısm and its musammä (cf Iḍ. 43, 11-2) 
matical methods. ${ }^{20}$ The attitude of many scholars towards logic and the logical element in grammar may be deduced from their views about the use of analogy (qiyās). ${ }^{21}$ At first there was a strong opposition against the use of the 'causal analogy' (qiyās al-'illa), in which the conclusion arrived at by analogy follows necessarily and inevitably from the premisses. ${ }^{22}$ For the orthodox this amounted to blasphemy, since it implied a restriction of the omnipotence of Allāh. The most outspoken on the subject were the Mu'tazilites who held the existence of causality in nature, that is: natural phenomena happen as the result of natural laws which have been instituted by Allāh. According to the orthodox theologians, things happen in nature because Allāh wishes them to happen. Applied to analogy this means that the conclusion of a reasoning is true not because of the validity of the logical principles concerned, but because of the will of Allāh, Who in this case permits the conclusion to be true always, although $\mathrm{He}$ could change that truth if $\mathrm{He}$ wanted to.

In speech we find causality-at least according to the $\mathrm{Mu}^{\text {'tazilite }}$ grammarians-in the theory about the 'determinants' ('awämil): the different endings of nouns and verbs in the declension are caused not by Allāh, but by the speaking subject. ${ }^{23}$ Grammarians distinguish between 'ämil lafz̧i and 'ämil ma'nawi, but according to Ibn Ğinnì this does not imply that the words themselves, present or absent in the sentence, cause the endings: it only means that sometimes our action, which causes the endings, is accompanied by a visible sign, and sometimes it is not. Man himself is the real 'amil, not only in the declension, but also with regard to speech in general: hence the typically $\mathrm{Mu}$ 'tazilite statement that speech is an act of the speaker. So we find in al-Gubbā'i (d. 915/303), teacher of the theologian al-Ašari and the grammarian as-Sìrāfi: '(Allāh) utters the speech which He creates in a substrate. But real speech ... is articulated sounds and letters (i.e. consonants) in a certain order. The real speaker is he who

20 We also point to Zağğăğìs ınsıstence that every statement about speech be proved rationally, cf. Iḍ. 41, 16- 42, 10.

21 Brunschvig, 1970.

22 Cf. above, chapter IV; Frank, 1966.

23 Mahzūmi, 1958, 2646; cf. b Gın. Haș. 1, 109-10 Zağğāğì does not say explicitly that man is the "ammil of the declension, as Ibn Ginni says, but it seems to be evident from his remarks on the use of the declension and its introduction into speech that in his opinion man provides words with the endings of the cases (Id. 69, 8- 70, 2). This conforms to the Mu'tazilite doctrine on the human origin of speech, cf. below, chapter IX. 
creates speech, and not he who is its substrate'. ${ }^{24}$ Everything turns on the question what we intend by giving a person the attribute mutakallim (speaking). The connection between this question and the problem of the creation of the Qur'an may be studied in the seventh book of 'Abd al-Gabbār's Mugnni fi abwäb at-tauhid wa-'l-'adl, which deals with the Halq al-Qur'än, especially in the chapter which is entitled 'On the fact that the real condition of the speaker is that he brings speech into being by himself, in accordance with his intention and his will'. ${ }^{25}$ 'Abd al-Gabbār begins by reasoning with one of his characteristic grammatical arguments: according to grammatical rules the meaning of the expression huwa mutakallim (he is speaking) is fa'ala 'l-kaläm (he made speech), just as we say huwa dârib (he is hitting), i.e. fa ala 'd-darb (he made blows). The grammarians, however, are not competent to judge whether a person really creates his act, whether he is its muhdı (creator, innovator): grammarians are not able to say anything about the theological implications of the verb fa'ala. But, leaving the grammatical facts for what they are worth, we may indeed conclude by way of logical reasoning that that person does create his act. Most certainly the grammarians would also reach this conclusion, if only they would use the method of logical reasoning. It follows that we must accept the literal text of the Qur'ān where it says that Allāh is speaking. We must conclude from this text that $\mathrm{He}$ is really speaking, ${ }^{26}$ that $\mathrm{He}$ really makes His speech-which means that the Qur'ān is created. On the other hand, when Allāh creates speech in a person, we cannot say that that person is speaking, by virtue of the creation of speech into him, because he does not really produce his speech himself. But when we are reciting the Qur'ān, it is our own action, and we ourselves are creating speech-this speech being an imitation of Allāh's words. ${ }^{27}$ We may compare with this a quotation by Zağğăği : 'speech is made by a speaker, for he produces

24 Ap Sahrastānī. Mılal, 1, 54, 15-7 [A95], ef Bouman, 1959, 25, Frank, 1966. 245

25 Abd al-Gabbūr. Mugni, 7.48 sq9 [A 96] Mutakallım is not used in the Qur'ān, but cf cg 4 164. for the creation of the Qur'ān Nader, 1956, 99-113

26 The same sort of reasoning with the Hanbalite Ibn al- Aqil (about 1095/490), who uses it in order to prove that Allāh really spedks with audıble sounds (agaınst the Aštarite doctrıne). Rasà̀l, pp. 22-3

27 On the recitation of the Qur`ān being an imitation of Allāh`s words. Bouman, 1959. 15, 24, on the Ǎ̈arite point of view'b 'Aqïl. Rasa'ıll. 22. 18-20 'According to them (sc the Ararites), the recitation and the reading and the writing (sc. of the Qur'àn) are created But the Qurān itsel is an attribute which resides in the mind of the speaker. not perceptuble to the senses of the belıever, and the sounds and the letters are only an imitation of It $^{\circ}$ [A 97]. 
it, while before it did not exist; therefore, it is an action on his part' ${ }^{28}$ in other words, the speaker creates his speech.

We find the same linguistic reasoning in Ibn Ginni in a polemic with Abū 'l-Hasan al-Ahnfaš: 'Do you not see that each of us when he is speaking, only deserves that attribute (sc. the attribute "speaking") by virtue of his own speaking, not by virtue of something else, or by virtue of His creating speech in his instrument of articulation. He would not be speaking (sc. he would not deserve the attribute "speaking"), unless he moved his own articulatory organs'. ${ }^{29}$ Returning to Zağğàğì, we notice that he talks about this originally theological thesis, because it has been used by an adversary to attack the usual classification of the parts of speech. For, the adversary says, if every word is an action $\left(f^{\circ} l\right)$ on the part of the speaker, why then do the grammarians distinguish between asmā', af $\bar{a} l$ and hurūf? Zağğāăì agrees with the theological thesis, but according to him, it cannot be used as an argument against the usual classification of the parts of speech because of the unequality of the two levels of the discussion: there is no real contradiction, since the terminology and classification of the parts of speech are based on grammatical facts and on the grammatical differences between the parts of speech. Exactly the same answer is given by 'Abd al-Gabbār to the objection that the grammatical classification invalidates his definition of speech as consisting of 'letters in a certain order' (hurūf manżuma). He answers: 'What is said by the experts of the Arabic language does not contradict what we said. When they say "speech is noun, verb, and particle with a meaning", they are talking about the speech as we have defined it; they divide it into different parts, without denying that speech in its totality consists of letters with a special arrangement'. ${ }^{30}$

The opposite opinion about the action of the speaker says that, on the contrary, every action belongs to Allah alone, Who is the Creator of everything. This positıon was defended by Ibn Maḍa' of Córdoba (d. 1195/592): 'The doctrine of the people of the truth (i.e. the orthodox Zāhirites, like Ibn Hazm and himself) is that these sounds are only an action of Allāh the Lofty; their connection with man is the same as the connection of the rest of his voluntary actions with

2s Zdğg ld 43, 10-1 Cr Kındī's definitıon of creatıon ( appear out of nothıng' (Izhär aì-ial' 'an lasa). Rasā'1l, I, 165, II. For the Mutazılıte creato e minlo. Waleer, 1962, $187 \mathrm{sqq}$

29 b Gin $\underline{H}$ as. 2, 454, 6-8 [A 98].

30 'Abd al-Gubbār. Mugni, 7, 9, 4-6 [A 99], cf b 'Aqīl, Rasàìl, 9, 13 sqq 
him'. ${ }^{31}$ A compromise between the two extremes was formulated by al-Ašarí; this compromise was finally accepted by the majority of the orthodox theologians. ${ }^{32}$

The influence of the Mu'tazila is also discernible in the partly theological, partly grammatical debate about the question whether words are identical with their nominata (the things denoted by them), or with the act of inventing the words for the nominata, that is with the act of using the words. The first thesis was opposed by almost all grammarians according to Mu'tazilite doctrine, which held that words were identical with the act of using them. In the discussions about this subject, many difficulties arose from conflicting interpretations of the term musammā. Zağğāği makes clear ${ }^{33}$ that nomen and nominatum cannot simply be put on a par: in the sentence zaid qa' $i m$ (Zaid is standing), the word zaid is not identical with the person, Zaid, whom it denotes, and the verb $q \bar{a}$ 'im cannot be held to be identical with the action of that person, ${ }^{34}$ because both words, zaid as well as $q \bar{a} ' i m$, are actions of the speaker (af âl al-mutakallim). ${ }^{35}$

Ibn Ginni proposes a grammatical proof of the distinction between ism and musamma $\bar{a}$, which may be summarized as follows. ${ }^{36}$ An adjunction (ida $\bar{a} f a$ ) of a nomen to a nominatum is possible; they can, therefore, not be identical, since it is not allowed to connect something with itself. ${ }^{37}$ When we look at the examples of such an adjunction of a nomen to a nominatum, it becomes clear what the meaning of musamma $\bar{a}$ in this context is: in the expression hâda $\underline{d} \bar{u}$ zaidin the meaning is häda săhib häda 'l-ism alladi huwa zaid (he is the possessor of the name Zaid), or in other words häda huwa l-musammā bi-häda ' $l$-ism (he is the person who is named by this name). ${ }^{38}$ Another example is the common expression kāna indana dăta șabāhin (he was with us on a certain morning); the meaning of this expression is kāna 'indanā 'l-waqt al-musammā șabăhan (he was with us at the time

31 b Madā’, Radd 87 [A 100], cl Mahnzūmi, 1958, 265 sqq , Arnaldez. 1956, 89. Mubārak, 1974', 148-58, 'Id, 1973, 251-62

32 Ašari, Ibāna, 52-5, cf Watt, 1971, 27, Frank, 1966

${ }^{33}$ Zağğ Id 43, 11 sqq . 57, 4 sqq

${ }^{34}$ Besides. zard is not the real agent, but only d grammatical one, cf Rāzí, Maf

$1,55,11 \mathrm{sqq}$

${ }^{35} \mathrm{Cf}$ above, notes $24-8$

36 b Gin Has 2, 188, 10-2, 3, 24, 3-4

${ }^{37} \mathrm{Cr}$ above. chapter VI, note 55, and Zağğ Id 109, $15-110,16$

is b Gın $\underline{H} d s$ 3, 27, 9-10, the example comes vıa Abū 'Alī al-Fārısĩ from Ta'lab's teacher. an-Nadim 
which is called morning) ${ }^{39}$ In these and similar examples the nominatum (musammä) is that which is named by the nomen (ism), in other words, $\underline{d} \bar{u}$, dät in the sentences quoted are the nominata of the nomina zaid, sabāh. ${ }^{40}$ This means that a word may be nomen or nominatum, depending on the use we make of it: if I ask someone 'what is the spelling of sayf (sword)', and he answers $s-y-f$, then we are talking about a nomen. But when I say 'I hit him with a sayf, with a sword', then I am talking about a musamma $\bar{a}^{41}$ In the first example, the nominatum of the word sayf is a nomen, in the second example it is a nominatum. As a matter of fact, we are dealing here with the distinction between the first and the second name-giving, ${ }^{42}$ or, to put it in modern terms, between language and meta-language.

Ibn Ginni also asks how it is possible that some people believe that nomina and their nominata are identical. His answer is that it is customary to use the nomina in talking about the nominata. In fact, the nomina are the only way to 'reach' the nominata. For this reason, some people thought that they could be used indiscriminately, and that, consequently, they were identical. ${ }^{43}$

A new element is brought into the discussion by Gazzāli, viz. denomination (tasmıya). ${ }^{44}$ According to Gazzālì we must distinguısh between three elements: the nomen, its nominatum, and the act of giving a nominatum a nomen. As for the identity of the nomen and the nominatum, he mentions three theories. The first of these theories holds that all nomina are identical with their nominata. The second theory holds that this is nowhere the case. The third theory asserts that there are three sorts of nomina: those which are identical with their nominata (e.g. Allāh, mauğūd (Allāh, existent)); those which are not identical with their nominata (e.g. häliq, (creating), because this word is not only connected with Allāh, but also with the thıng

39 b Gin Has 3, 32, 1-3

${ }^{40} \mathrm{Cr}$ Id $57,8-9$ the verb is the musamma of the noun, because the masdar is called the ism al-fil

41 b Gın Has 3, 31, 5-10

42 Cf below, chapter IX, note 47

43 For the expression al-ism dalil al-mainā, cf Gazz Asmā', 6, 12 al-madlūl alaıhı (= al-musammā), and Zağğ Id 50,4 (al-ism mä dalla alä $\%$-musammā) That we can reach the nomınata only through the nomınd is said by Zağgàg $\bar{i}$, Id 56, 5-6, cf below, note 75

44 Gazz Asmā', pp 4 sqq On Gazzāli’s theorıes Gatje, 1974 
created); and those about which neither the first nor the second property can be predicated (Allāh's inherent attributes). ${ }^{45}$

The word Allah, which is used as an example of the words of the first category - those words which are identical with their nominatais used also by 'Abd al-Gabbār. ${ }^{46} \mathrm{He}$ uses it to refute precisely the theory about the identity of nomen and nominatum. If the word Allah were indeed identical with its nominatum, then it would be eternal-which is, of course, impossible in 'Abd al-Gabbār's theology ${ }^{47}$ Nor can the names of Allāh be identical with Allāh, because $\mathrm{He}$ is One, whereas His names are various and diverse. ${ }^{48}$ On the other hand, the advocates of the identity of nomen and nominatum assert that precisely the eternity of the word Allah is proof of the eternity of the Qur'ān-which can, therefore, not be a creation by Allāh. In Sahrastānī's Milal we find the statement that Allāh's attributes are identical with $\mathrm{His}$ essence, because there cannot exist any plurality in His essence. ${ }^{49}$

The element of the tasmiya is also mentioned by al-Bāqillāni (d. $1013 / 404$ ), who deals with the theory of the identity of the nomen and the nominatum in his Tamhid. ${ }^{50}$ The orthodox opinion, he says, is that nomen and nominatum are identical-which shows that the majority of the grammarians in Baghdad were not orthodox at the time, because they all agreed that the nomen is something else than the nominatum. ${ }^{51}$ The Mu'tazila held, according to Bāqillāni, that the nomen is identical with the tasmiya, i.e. the namegiving. The same theory is also explicitly attributed to the Mu'tazila by Ibn Hāğib

45 The same classıfication is used by Baıdāwĩ. Similar classificatıons in three categorıes (a, not-a, neither a nor not-a) in Stoic writıngs, e.g. In ethics the division of objects into good, bad, and indıfferent (SVF 3, pp 28-30; cf. Jadaane, 1968, 191, van den Bergh, 1954, 2, 117); also Poseidonios' definition of dialectics as the science of truth, falsehood, and what is nether (SVF 2,122), other connectıons, with Christian theology . van Ess, 1965, 119-20 On the doctrıne of the attributes of Allāh. Pretzl, 1940; Allard, 1965, Frank, 1969

46 Abd al-Gabbār, Muġni, 7, 164, 10; 7, 165, 7.

47 As is asserted by Gazzālī, Asmā 4, 7: 'as when we say that Allāh-He is Lofty-

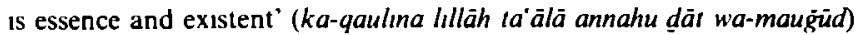

48 Van den Bergh, 1954, 2, 128, note $2192 \cdot$ according to Ibn Hazm, Bāqillāni held that Allāh has only one name, but many appellations (tasmıyăt) For this distinction, cf below, note 57 and 70

49 Sahr. Milal, 34; Pretzl, 1940, 11.

so Bāq Tamh., 227-36, also id. Insāe, 47.

51 Which was to be expected in view of the fact that many grammarians belonged to the Mutazila, cf above, notes 2 and 5 
(d. 1248/646) in his I lăh sarh al-mufașsal: ${ }^{52}$ 'Some of them say that the ism is the tasmiya, and this is the doctrine of the Mutazila and of the grammarians and of many jurists. Others say that the ism is the musammā, and this is the Ašarite opinion'. It is hard to explain why this theory is mentioned nowhere else in grammatical writings. ${ }^{53}$ It is not clear what exactly is meant by tasmiya: one is tempted to interpret the Mu'tazilite theory of meaning in terms of 'use', i.e. meaning is the sum total of all concrete uses of a word, but probably this is too modern an interpretation.

It is not easy to understand what is meant by the word musamma in these discussions, since two different meanings of the word are being used at the same time. Gazzālī's theory of signification distinguishes between three modes of being: ${ }^{54}$ a physical level, a psychological level, and a linguistic level; words correlate within this frame with concepts in the mind (suwar dihniyya), not with objects in the outer world. ${ }^{55}$ In that case, musamma is clearly the 'imaginary' correlate of the word, not the concrete thing denoted by the word. This is the meaning of musammā for Gazzālì as well as Ibn Ginnì.

On the other hand, "Abd al-Gabbār uses in his refutation of the theory that ism and musammā are identical, arguments which are only comprehensible if by musammā we understand the concrete thing denoted by the word. The same meaning of musamma is used by the adversaries of Bāqillāni: they argue that if the nomen is identical with the nominatum, then by saying the word 'fire', we would burn our mouths, and by saying the word 'zaid', that individual would be present on our tongues. Here musammà means the concrete thing denoted by the word. ${ }^{56}$ Băqillānìs answer is: 'This is talk of the man

52 Ibn al-Ḥāğıb, Idāh. p 107, quoted by Sàmarrāì, 1971, 215-6 [A 101].

$53 \mathrm{Cr}$ van Ess, 1965, 117-8

$54 \mathrm{Cr}$ below, chapter IX, note 50, Gätje, 1974, 161, sqq. (Gazzālīs theory of identity and diversity as it is applied to the problem of the ism and the musamma. 168-75).

5s Gazz. Asmā', 6, 10 sqq remark on the difference between the notions wad, maudü, and maudü' lahu

56 We are reminded of the Stoic paradox of the wagon (whatever you say passes through your mouth, you say 'wagon', therefore, a wagon passes through your mouth), de $R_{1 j k}$, 1968, 98-9 That the argument may also be used the other way round, may be seen in a completely different context, namely in the controversy in Indian grammar concerning the natural relationship between a word and its meaning. It is there argued by the adherents of the Vaisesıka school that words do not co-exist with the objects they denote. the word 'fire' does not burn the mouth, and the word 'razor' does not cut it, nor does the word 'honey' sweeten it (cf. Kunjunnı Raja, 1969², 22) 
in the street, and typical of ignorant people, because the words "fire", "zaid", which are present in our mouths, are not the name of Zaid, nor the name of the fire, but only a denomination (tasmiya), and an indication of those names. Their argument does, therefore, not apply.' ${ }^{57}$ In other words, ism is a sort of idea which is inherent in the objects and which is identical with them, whereas the sounds of the physical word are an indication (daläla) of those asmä'. We do not doubt that this argument of Bāqillāni's adversaries is one of the arguments used by the Mu'tazila. We may compare with it 'Abd al-Gabbār's argument that, if ism and musammā were identical, the word Alläh would then be eternal.

The difficulties concerning the meaning of musammä are also mentioned by Baidāwī (d. 1286/685) in his commentary on the Fätiha. ${ }^{58}$ He says that the thesis of the identity of nomen and nominatum may be accepted with a certain reserve. If by ism we understand the physical words (alfäz), there can be no question of an identity with the musammayāt, i.e. with the concrete things denoted by the words, because in that case the two notions are incomparable, they are not on the same level. If, however, by ism we understand 'the essence of the thing' (dät aš-šay') - a meaning the word does not possess normally-then it is identical with the musammā. A third possibility is that we understand by ism an attribute of Allāh (e.g. in the Qur'ànic text sabbih ism rabbika (worship the name of thy Lord) ${ }^{59}$ ). In that case, we must distinguish between essential attributes, which indicate the essence of the thing (nafs aś-say'), non-essential attributes, and in the third place, indifferent attributes, i.e. those about which neither of the two things can be predicated. ${ }^{60}$ Apparently, there can be only identity of ism and musammä in the case of attributes of the first category (al-Ašarī, according to Baiḍāwī ${ }^{61}$ ).

\footnotetext{
97 Bāq. Tamh. 232, 12-6 [A 102].

s8 Basd. Tafsīr, 4, 7-14, cf. also al-Azharī, Sarh at-tașrîf alā 't-taudih, 1, 7, quoted by Sāmarrāìi, 1971, 215-6

39 Qur'ān, 87/1.

60 This classification of the attributes remınds us of Gazzāli, cf above note 45, cf. Gätje, 1974, 155-8; 175-7

o1 According to Bagdādi, Uşūl, 114 (d. 1037/429), quoted by Pretzl, 1940, 20, Aš’arì defended the orthodox thesis of the identity of name and thing named in his book on the explanation of the Qurān, but in his book on the attributes of Allāh, he divided the names of Allāh according to Hıs properties. Cf. Ašari's discussion concerning the names of Allāh, Ibāna, p. 24, namely the problem whether they are created or not He there concludes-from the Qur'ānıc text rabärak ısm rabbıka-lhat these names cannot be created, and are, therefore, identical with His essence But Sahrastāni, Mılal, 34,
} 
Rāzi's account ${ }^{62}$ completes the picture. His method resembles the method used by Gazzālī, in so far as he also includes the notion of tasmiya in his discussion. He even mentions the fact that the identity of ism and tasmiya was proclaimed by the Mutazila (and he refutes this thesis ${ }^{63}$ ). We believe that, on the whole, Rāzì's discussion served as a model for Baiḍāwi. Rāzì says that the theory of the identity of ism and musammā was chosen by the Ašarites. ${ }^{64}$ Apparently it is rejected by the Mu'tazilites, because that school had a theory of their own, which held that the ism is identical with the tasmiya. We have seen above that both Ibn Ginni and 'Abd al-Gabbār rejected the identity of nomen and nominatum; both were of $\mathrm{Mu}$ 'tazilite confession. Rāzi admits, furthermore, that, if we use ism in the sense of 'essence of the thing' (d̄ăt $a \bar{s}$-šay'), it is indeed identical with the musamma although in that case the whole theory is a mere tautology (idäh al-wädıhât). The arguments used by the advocates of the theory are various, he says, the most important ones being the text of the Qur'ān (tabārak ism rabbika, cf. the above cited sabbih ism rabbika), and another argument connected with the formula of divorce. ${ }^{65}$

The names of only a few authors are mentioned in connection with this theory. Of the grammarians we have found only the name of Abū 'Ubaida (d. 825/210), the teacher of al-Māzini. ${ }^{66}$ We are told that one of the arguments he used was the text of the Qur'ān (sabbih ism rabbika). From the same source we hear that Sibawaihi opposed the theory. ${ }^{67}$ It is small wonder that the majority of the grammarians did not favour the theory of the identity of nomen and nominatum, because the number of Mu'tazilites among them was considerable. As we have seen, the Mu'tazila rejected this theory.

cf Pretzl, 1940, 11, tells us that As'ari affirmed that in Allāh all opposites are destroyed, which implies that it cannot be predicated about His attributes that they are identical with Him, nor that they are not identical with Him (coincidentia oppositorum), of van den Bergh, 1954, 2, 128, note 2191

${ }_{62} \mathrm{R} \bar{a} z i \overline{1}$, Maf 1, 108-10 Cf also Anawatı, 1974, 363-6, concerning Rāzīs discussion of the various arguments for or against this theory in his Lawämi al-bayyınä fi '/-asmä' wa-'ș-șıfät (ed Caıro, 1914, pp 3-10)

63 Rāzi, Maf 1, 110, 2-4 sqq

${ }^{64} \mathrm{Cf}$ above, note 52

65 Rāzì, Maf 1, 110

66 Lisān, s v $s-m-w, 14,402,7-11 \mathrm{r}$, on the authority of Abū 'l-'Abbās, 1 e alMubarrad, a pupıl of Māzıni’s Cr Abū 'Ubaıda, Maḡāz al-Qur'ān, ed M F Sezgın, Qāhıra, 1954, 1, 16, 8

67 Lisān, ib 402, 1 This is indirectly confirmed by the fact that the question, Id 11, 8 is put to the followers of Sïbawathı, but probably, Sibawaihı hımself was too early for this discussion 
Originally, the problem was a theological one with rather grave consequences for the idea of one God: if we accept the identity of nomen and nominatum, then we must also accept the eternity of the words, which in the case of Allāh contradicts the Mu'tazilite doctrine. ${ }^{68}$ The $\mathrm{Mu}^{\circ}$ tazila therefore opposed the theory in the first place. Their argument was the incompatibility of the unity of Allāh with eternal and different names. ${ }^{69}$ The grammarians among the Mu'tazilites adduced grammatical arguments to prove the impossibility of the theory, as in the case of Ibn Ginnī. The theory favoured by the Mu'tazila was the identity of ism and tasmiya, but we find Ibn Kullāb (d. 845/240) making an effort to distinguish between the two notions. He distinguished between the natural-conventional name which is given to something in a particular language, which is its denomination (tasmiya)' and 'the thing's necessary and universal meaning or intelligible idea, which is its true name (ism)'. ${ }^{70}$

No arguments of a grammatical nature are found in favour of the theory of the identity of ism and musammä: the only grammarian whose name is connected with it, Abū 'Ubaida, apparently restricted himself to theological arguments. Zağğāği lived at a time when the problem had ceased to be a controversial issue for grammarians, and he mentions it rather as a sort of commonplace objection, which does not need to be refuted, since everyone knows it is based on an incorrect theory. It is important to keep in mind that the original issue was the identity of words and the objects denoted by them. Only later did the problem, which was originally a theological one, change into a semantic one, namely the identity of words with their meanings. This change was partly caused by the need to find new, grammatical arguments against the old theory.

There is perhaps a parallel between the original problem and the Aristotelian theory that thought and the object of thought are identical

os $\mathrm{Cf}$ the orthodox statement in Bagdādi, Usūl, 114, If names were really dıfferent from the things named, then Allāh would not possess names and attributes from eternity, Pretzl, 1940, 20

${ }^{69}$ Concerning the nature of the discussion, which was rather primitive, of Pretzl, 1940, 20 Diesem Problem sehen dle Mutakallımün aus Mangcl an dialektıscher Schulung doch schr hilflos gegenuber "Gleıchsein" oder "Verschiedensein" sind die eınzigen viel zu groben Denkmittel, mit denen sie um die Sache herumraten"

to Cr Mahdı. 1970. 59, this theory was advanced by the grammarian Sirāfi in his discussion with Mattā ıbn Yūnus (cf above, chapter VI) For the doctrıne of Ibn Kullāb, Bouman, 1959, 37-8, van Ess, 1965 Ibn Kullāb was not a Mu'tazılıte, but an independent thinker In some respects his doctrine is reported to approximate that of the Christians, of Nader, 1956, 99, note, Sezgın, 1967, 1599 
-except when we conceive of thought as an act-: if this identity would not exist, we could only have an impression of the truth, never truth itself, because our thought would in that case be different from the truth. ${ }^{71}$ This theory is also dealt with by Plotinos and by Alexandros in his commentary on Aristotle's De Anima. ${ }^{72}$

Aristotle even mentions that nomen and nominatum may be confused, in approximately the same terms as Zağğāğì: 'As we cannot reproduce the objects themselves in speaking, we use words instead of the objects as symbols. Consequently, we tend to believe that what applies to the words also applies to the objects, just like the numbers in arithmetic. But there is a difference: words are finite, as is the number of sentences. But the objects are infinite. Thus, the same sentence and the same word must needs signify more than one thing'. ${ }^{73}$ Augustinus discusses the same problem as follows: 'As we are not able to speak about words unless with words, and as we speak, when we speak, only about things, it may occur to us that words are signs of things without ceasing to be things themselves'. ${ }^{74}$ There is a strikıng resemblance with Zağǧāğì's words: "The term "nouns" can take the place of the term "what is named by the nouns" when something is told about them ( $f \bar{i}$ ' $l-l \mid l h a \bar{a} r$ 'anhā), for you can only get hold of (the nominata) through (the nouns), as we have mentioned'. ${ }^{75}$

71 Van den Bergh, 1954, 2, 120, note 201 2, Islamic philosophy, 1972, 29

72 Plot Enn 5, 3, 5, Alexandros of Aphrodisids, comment in Aristot de anima, (Ardbic transldtion), Baddwī, 1971. 34-5 Cf also Proklos, scholid in Pldt Crat 6, 8-9

73 Aristol soph el 165 a 7-13 [G53], of Steinthal, 1890², 1, 190-1, Coseriu, 1970. 70, 79-80 On the Arabic translations of the Sophssuc Elenc/u Badaw1, 1968, 77 The infinity of things as compared with the liniteness of words Suy Muzh 1. 26 pen - 27. 2, Ràzí, Md 1, 24, 2-4, above, chapter VII, note 39 In literary theory the argument of the infinity of things is used in the discussion concerning išturäh, the usc of one expression lor more than one concept Word are formed from finite letters, and are. therefore, finite. they are used to express an infinite number of things, therefore, iśtıräh exısts by necessity This argument is used by Sdlāh ad-Din Halil tbn Aybak as-Saladi (d 1362/764, cf Hrockelmann, GAL II, 3I. S II, 27) in his Fadd al-hrtäm "an at-taurna wa- $/-$ sulidäm decording to Bonebakker, 1966, 89 In another context the infinity of the ma'an as compared with the finiteness of the alfāz is used as an argument for the superiority of the artist, who has to select the right word for a meaning, ef Heinrichs, 1969, 70-I

${ }^{4}$ August dialect c 5, 8, 1-3 nam cum de lerhs loqu mst verhis nequeamus at cum loqumu nonmst de aliqubus robus loquamur. occurrit ammo tha esse lerba signa renum, ut res exse non desmanl Cf Barwick, 1957. 11

75 Zdğğ ld 56, 5-6 [A 103] 


\section{THE ORIGIN OF SPEECH}

and particularly the theory of names happens to be a rather complicated problem ' '

It is a wellknown fact that Islamic theology had an enormous influence on the linguistic studies of the Arabs, ${ }^{2}$ and considering the number of grammarians with Mu'tazilite views, we cannot but expect that the Mu'tazila, too, exercised some influence in this field. We can detect the Mu'tazilite influence particularly in the ideas about the nature and origin of speech. Although we do not believe in a Mu'tazilite 'liberal humanism', we do believe that their preference for logical, i.e. Greek methods, and for rational thinking, led them to a more anthropocentric conception of speech. On the other hand, it is certainly wrong simply to deduce from the Mu'tazilite doctrine of the creation of the Qur'ān by Allāh that the Mu'tazila considered speech a human invention: ${ }^{3}$ it is very well possible to conceive of a doctrine which contains both the creation of the Qur'ān and of speech by Allāh, without diminishing man's free will. Nevertheless, our sources indicate that the combination of Mu'tazilite ideas and a conventionalist theory about the origin of speech was fairly common, though there are exceptions, as is proved by the case of Abū 'Alī al-Fārisi. ${ }^{4}$ Moreover, we find that it is possible to deny the creation of the Qur'ān by Allāh and at the same time to believe in the human origin of speech. ${ }^{5}$ In short, the conventionalist theory is neither a necessary nor an exclusive condition for Mu'tazilites.

As a matter of fact, it is impossible to understand properly the ideas of the Arabic grammarians and theologians with regard to the

1 Platon, Crat 384 B [G 54]

2 Cf e g Kopf, 1956, Weiss, 1966, 1974

${ }^{3}$ Conira Loucel, 1963, 275 (44) 'Mais que reste-t-1l du Mu'tazilisme si la langue est consıdérée comme révélee par Dieu? En quol le libre arbitre humaın pourra-t-1l désormals s'exercer? ', for the Mu'tazilute theory Nader, 1956, 255-7

4 The astonishment of Loucel $(1963,275(44))$ and Kopf $(1956,57)$ at this fact does not seem to be justified

${ }^{5}$ Contra Loucel, 1963, 199 (12) Qui affirme que le Coran est incréé peut difficilement soutenır l'origine humane du langage' 
origin and nature of speech without comparing them with the data from Greek grammar and philosophy. It is important to keep in mind that the history of this problem is a complicated one because of the constant change in meaning of the terms used in the discussions about this problem. We shall see that several terms have been borrowed from Greek discussions by Arabic grammarians, even when the framework of these discussions was completely different from the Arabic point of view. In connection with this, we refer to Steinthal's methodologically important observation: 'Solche Schlagwörter ändern, ..., mit der Zeit und mit den Vertretern und mit der gegenseitigen Stellung der Parteien ihre Bedeutung; die Geschichte der Parteien, die Entwicklung ihrer Kämpfe, liegt gerade in der veränderten Bedeutung der oft unverändert gebliebenen Namen'. ${ }^{6}$ The two words most frequently used in these discussions, phusis and thésis were not meant originally to indicate the origin of speech, but the epistemological value of speech, i.e. the possibility to understand the nature of the things through the words which signify them. Speech is phusei when it gives us an insight into the nature of things, when the form of the words tells us something about the nature of things; speech is thései when it contains only words which have been chosen or agreed upon arbitrarily and independently of the things they signify. In both cases, the origin of speech remains an open question: in both theories, it may be due to a divine or a human name-giver, to nature, or to the community. In later times, the terms phúsei and thései were also used in the discussions about the origin of speech, whence the ambiguity and the pointlessness of some of these discussions. This fact was already known in antiquity, for instance by Proklos in his commentary on Plato's Cratylus, ${ }^{7}$ and by Ammonios in his commentary on Aristotle's De Interpretatione. ${ }^{8}$ According to these sources, the word phúsis has several meanings. ${ }^{9}$ Kratylos uses it in Plato's dialogue of

- Steinthal, $1890^{2}, 1,75$

7 We do not agree with Steinthal, when he says that Proklos 'sıch vollig unfahıg (zeigt) einen getreuen Bericht über alte Philosopheme zu geben'. (1890², 1, 170) On the whole, the remarks of Proklos (and Ammonios) bear witness to a keen insight into the different meanings of the key-words What is true, though, is that he tends to over-systematisize and to project new opinions back into older writings On Proklos. Daniélou 1956

B Amm. in Aristol de interpret 34-5, ed Busse

9 For the four meanings of phusel Prokl comm in Plat. Crat par 17 ... because the term "by nature" (phisel) has four meanıngs it may be used to indicate living beings, anımals, or plants, as a whole or in part, it may be used to indicate their 
the same name to indicate that things receive their names according to their nature, and that therefore these names indicate those things naturally, i.e., in a natural way, so that the sounds of the word imitate the nature of the thing. ${ }^{10}$ But speech may also be said to be phise $i$ because it is made up of something natural, something physical, viz. sounds. " Epikouros and Lucretius use the term in still another sense: words originate in a natural way; just as animals make natural sounds, man began to use natural sounds in order to indicate things, though arbitrarily. ${ }^{12}$ The opposite of phúsis is the term thésis: some people mean by this that words signify things as the result of an arbitrary agreement between the first men, ${ }^{13}$ whereas others understand by thésis the action of a wise name-giver, who understood the nature of things and expressed it in appropriate words.

The doctrine of the Stoics constitutes as it were a compromise between the various theories; it came to be accepted by the majority of the grammarians, and so found its way into the schools. ${ }^{14} \mathrm{We}$ believe that the Stoic theory was one of the major sources of the

potential or actual properties, for instance the lightness and the warmth of fire; it may be used to indicate the shadows and the images in a mirror; or it may be used to indicate a picture made by an artist, which resembles its model . ' [G 55]. According to him, Kratylos used phuses in the second meanıng, Epikouros in the first; cf. Steinthal, $1890^{2}, 1,168-82$ and note 10 and 12 below

10 Kratylos speaks the truth when he says that a thing has a name according to its nature (phusei), and that not everybody is able to be a maker of names, but only he who takes into regard the natural name of everything, and who is able to express its essence in letters and syllables', Plat. Crat. 390 D-E [G 56] For the interpretation of the Crarlius I refer to the fundamental work of Derbolav, 1972, which gives an almost exhaustive survey of older interpretations and literature

${ }^{11} \mathrm{Cf}$ Alexandros of Aphrodisias ap Amm in Aristot. de interprel 39. 14-7, ed Busse. ' . the syllogism presented by the commentator from Aphrodislas (sc Alexandros), which scems to prove that nouns and verbs are only natural (phisel) for nouns, he says, and verbs are sounds, and sounds are natural; therefore, nouns and verbs are natural' [G 57] $C r$ the Arabic translation of Alexandros' treatise on sound, Badawi 1971,31 .

12 For the Epicurean analysis of language Diog. Laert 10, 75 sqq., Lucr De Rer. Nat 5, 1019 sqq and Ernout/Robın's commentary in locum (Paris, 1962, 3. 138 sqq.), de Lacy, 1939, Schrijvers, 1974 Epıkouros' doctrine is a good example of the confusion in the terminology words are natural (phuser), but they are conventional at the same tıme which is mostly a statcment characteristic of the théset-theories '

1. In that case. it is synonymous with sumtheket, or if the emphasis lies on the traditionality of speech with nómôt, éthet

14 Pinborg, 1961. 125-6: Die am meisteten verbreitete Auffassung der Antike war die der Stoa. die auch von den Rhetorschulen mil wenigen Korrekturen angenommen worden ist. und so Zugang zur Algemeinbildung fand" 
Arabic theories, not least because of the great influence of the schools of rhetoric on cultural life in the Hellenistic countries. ${ }^{15}$

Traditionally we are told about the Stoic doctrine that, with regard to the nature of language, it held that speech is phusei, ${ }^{16}$ that there is a connection between the sounds of speech and the nature of the things signified by those sounds. It is true that the Stoics believed that in the first phase of the creation of speech, or rather, in the first creative activity of man in this field, the 'first sounds' (prôtai phônaí) ${ }^{17}$ showed a correlation between the essence of things and the form of the words. This correlation is proved by Chrysippos with the form of some of the personal pronouns. ${ }^{18}$ But after this first period of creativity, speech follows its own course and its own laws, thereby losing contact with the realia which are designated by the words. This is the period of the development of grammatical rules, but also the period of the denominative formations, which are irregular, i.e., which cannot be classified by rules. This distinction between two periods is important for the establishment of the value of words with regard to the essence of the things designated by them: in the first period, which is ruled by nature (natura), words express the essence of the things, but in the second period everything is ruled by grammar (ars) and speech becomes a traditional, conventional way of speaking (usus). Consequently, words lose their ability to express the essence of the things designated by them, and they change constantly. In order to rediscover the original words (the étuma which express the true essence of the things), the Stoa used certain etymological principles of a phonetic and semantic nature ${ }^{19}$ they even thought that with these

is Dasber, 1968, 93 s4q The schools of rhetoric in general: Marrou, $1965^{5}$

16 Origenes, Contra C' $'$ lsum, 1, c $24=$ SVF 2, 146 'The theory about the nature of the words. whether they are théset, as Aristotle thinks, or, as is held by the people of the Stoa, phisei, in so far as the first sounds imitate the things designated by the words They also use certain etymological principles in this matter' [G 58]

17 They are identical with Augustınus' cumahula verborum. dialcct VI, 10, 9, 11, 13 (= stirps), cf Barwick, 1957, 29-33

${ }^{18} \mathrm{C}$ S SVF 2, 895: a quotation by Galenos from Chrysippos' Peri psuchès. 'For we pronounce the word ego (I) by pullıng down our lower lip at the first syllable, thus indicating ourselves (pointing at ourselves); following this pointing gesture-the movement of the chin and the nod towards the breast-comes the next syllable (The word egó) does not point at anythıng outsıde us, such as is the case with the word ekeinos (he)' [G 59]: of Schmıdt, 1839, 23-5. In Latın grammatıcal literature, this example has been taken over by Publius Nigidus, who contrasts nos and vos the same way Chrysippos does with egó and eke'inos, cf. de R R jk, 1968, 92-3.

19 For the four categories of phonetic change (adiectio, Immulatı, transmutatıo, detractio). cf. above chapter II The semantic principles operate with the categories of 
principles every word could be explained. ${ }^{20}$ The Stoic etymological principles soon became common property of Greek grammatical literature, and they are used in Arabic grammar as well. Suyūtị defines etymology as follows : 'Etymology means deriving one form from another, where both forms agree in meaning and original content and the combination of consonants, so that the second form signifies the original meaning with a significant addition (in meaning), which is why they differ phonetically or morphologically ... ${ }^{21}$ Here we may see an echo of the Stoic doctrine: the change from original word to secondary word is irregular, but may be explained through a correlation between the change in meaning and the change in form. There are in fact two layers of speech, one of which is fixed by nature, whereas the other is the result of human activity and can be changed, or rather, is being changed all the time. This distinction between primary and secondary or derived words is most important in Arabic literature, which divides words into two classes, 'roots' ( $u s \bar{u} l)$ and 'branches', i.e., 'derived words' (fur $\left.\bar{u}^{\prime}\right) .{ }^{22}$ The two layers of speech are also called-if one looks at speech from a glottogenetic point of view-'impositions'. The doctrine of the two impositions of speech was known to the Arabs from the translation of the relevant passages in Ammonios' commentary on Aristotle's De Interpretatione, ${ }^{23}$ which constituted one of the major sources in relaying Stoic doctrines to the Arabic world.

True language (orthos logos), says Chrysippos, is just as natural (phusei) as are law and equity. ${ }^{24}$ In this respect, his views about the development of human society concur with those of the Sophists, who created the famous distinction between natural and conventional

similitudo, contrarium. and vic mitas, cf Barwick, 1957, 58-69 We find the same categories in Suy Muzh, l, cap 23-4, pp. 187-207 (on figuratıve speech (maḡäz) and etymology (ı́silquāq)).

20 August dialect. VI, 9, 18-9. Stotc autumant .. nullum esse verhum, cutus non certa explicart origo possit (The Stolcs assert ... that there exists no word whose origin cannot be determined exactly).

21 Suy Muzh. 1, 201, 5-7, a quotation from the Sarh at-tashil, probably the one written by Abū Hayyān al-Garnāti (d. 1344/745) [A 104].

22 The blurring of this distinction between the usül and the furü appears in the Làhirite system, which regards it as an encroachment upon the power of Allāh. 'Dieu n'a pas crée des radıcaux sur lesquels l'homme aurat eu la permission de broder pour les adapter aux besoins de ses libres entreprises intellectuelles. Il a créé les mots réels, sımples ou dérıvés, contenant en eux leur sıgnıficatıon, c'est-à-dıre la règle totale de leur usage' (Arnaldez, 1956, 86; cf also pp. 154 sqq.).

${ }^{23} \mathrm{C}$. above, chapter VI, note 38

24 SVF 3, 76, 46. 
Instıtutions (nómôl vs phisel) ${ }^{25}$ But the Stoa by no means regarded human inventions as being necessarily bad, as the Sophists had done. for the Sophists, the two poles 'natural' and 'conventional' stand in opposition; for the Stoics, civilization (ars) is something human beings achieve by means of their divine reason (ratı), which is a gift of nature ${ }^{26}$ Civil law, for instance, is the adaptation of common, natural law to the needs of civilization, but always in accordance with that natural law law is the highest reason, implanted in nature (lex est ratio summa insita in natura), ${ }^{27}$ and that natural law is the starting-point for instituted law (a lege ducendum est iuris exordium) ${ }^{28}$

In this way, Stoic theory provided a compromise between the two poles of ars and natura by claiming their essentıal identity: civilization is nature expressed by human custom (usus) These three categories exercised an enormous influence upon every theory of civilization, and, through these theories, upon general education throughout ant1quity. In the words of Pinborg: 'Aus dem beruhmten sophistischen Konflıkt phúsel contra nómôl . entsteht die vermıttelnde Theorıe vom Ternar der natura, ars, usus, das die Entwicklung aller menschlıchen Fahigkeiten und Institutionen bedingt, sowohl im allgemeinen als Stufen der Kulturgeschıchte, als im Individuellen als Prınzıpıen der personlıchen Ausbildung' 29

One of the most important facets of civilization is language, without which no convention between human beings is possible. We have seen that according to the Stoa, language is in origin a natural, physical thıng, consıstıng in 'first words' (prôtal phônai), which are placed on the right things in the right way ${ }^{30}$ This first stage represents the element natura Later, speech is codified and regulated by the element ars, the result being the usus, normal everyday speech

Hence it follows that we have to distinguish between basic words and derivatives. The basic words are words from the first stage of language. they are 'natural' (phúset), $1 \mathrm{e}$ they are in accordance with nature and they tell us something about the essence of the things denoted by them The derivatives are words of the later stages: they are more arbitrary and their orıginal form may have become confused

\footnotetext{
25 Steinthal, $1890^{2} .1,55-79$

26 SVF 3, 89, $30 \mathrm{sqq}$

27 Cic de leg 1,18

28 Ib 19, also SVF 3, pp 76-80

29 Pinborg, 1961, 136

$30 \mathrm{Cf}$ above, note 17
} 
by frequent use. This means that in order to trace them back to their original form we need a scientific discipline, the science of etymology. Later grammarians used this historical distinction in a more grammatical and less principal sense, when they spoke about the 'first imposition' and the 'second imposition' (prôtè thésis kai deutéra thésis), as an indication of the difference between 'root words' (protótupa) and 'derivatives' (parágôga). We find this for the first time with Dionysios Thrax: "A root word is a word that is said according to the first imposition, e.g. "earth"; a derivative is a word that derives its origin from another word, e.g. "earthly". ${ }^{31}$ The connection with the Stoic theories about the origin of speech is evident in a remark made by Choiroboskos: 'The root word resembles the first-created man; the derivatives those who have sprung from him'. ${ }^{32}$ In the same way, prima et secunda positio are used in Latin grammar, e.g. by Quintılianus : prima positio is the basic form of the word as against the composita, which stem from a later development. ${ }^{33}$ Later prima positio receives the meaning 'basic form of the word, from which the declined forms are derived.${ }^{34}$ Priscianus uses prima positio in this sense, ${ }^{35}$ and shows that he is aware of the original meaning when he says: 'The first imposition of the verb, which seems to have been proffered by nature itself, and: 'Therefore it is original, because it received the first imposition from nature itself. ${ }^{36}$

In all these examples the two stages of development, as we found them with the Stoics, have been put together, and have been transferred to actual, spoken speech. Instead of two chronological levels of speech we now have two coexisting categories of words: the basic words; and those words that have been more or less arbitrarily derived from them, thereby forming new roots. The relation between the two categories, the root words and the derivatives, is likened by Varro to a tree with its offshoots: 'As every offshoot is secondary by nature, because the vertical trunk from which it has sprung is primary, such is the case with the declension in words: homo (man) is the vertical, hominis (of the man) is the oblique, because it is declined

31 Dion Thr 25, 3-5 [G 60]

32 Chorrob 1, 108, 3.5 [G61]

${ }^{33}$ Quint instit orat $1,6,10,1,5,65$, c $1,6,22$

34 Char 228, 4, 330, 8, cf also 233, 4, Diom 344, 2, 349, 11, 356, 39, 384, 17

35 Prisc instit 8, 63/421, 26-7, 8, 72/427, 12

36 Prisc $11 \mathrm{cc}$ prima positıo verbı quae videtur ab ipsa natura esse prolata, est ıgitur primitiva, quae primam positionem ab ipsa natura accepıt 
from the vertical'. ${ }^{37}$ This resembles the Arabic division of words into $u s ̦ \bar{u} l$ and $f u r \bar{u}$; there is even a terminological resemblance. ${ }^{38}$ In Latin grammar, the ultimate criterion for the correctness of speech remains everyday use. ${ }^{39}$ We find the same division of words into two categories in Ibn Ginnī: 'People in their wisdom weighed the language of the Arabs, and found that it consists of two groups of words: the first category of words should be accepted as it is, involuntarily and intuitively, e.g. "stone", "house" ... The other category is the one that is found to be formed by analogical rules; it was not very difficult for people to get to know this category, so they were able to classify and to analyse it, since they could understand it .... ${ }^{40}$ Note that in Arabic grammar the analogical element is emphasized with regards to the derivatives; in Latin grammar a distinction is made between the analogical element (i.e. the declension) and the anomalous element (i.e. the derivatives proper). ${ }^{41}$

As we have seen in the preceding paragraphs, the original Stoic distinction between two stages of speech, between first and second imposition, between natura and ars, was modified into a distinction between two levels of speech, on a strictly grammatical basis, between simple and composite words. The original distinction remained in use, however, as a description of two chronologically distinct stages in the development of speech and grammar. The 'artificial' element was now represented by the grammatical categories and terms, whereas the 'natural' situation was that of speech without such classification. This is what has become known as the distinction between object speech and metalanguage. According to the classical theory, objects received their names in the first imposition; subsequently, these names received names themselves, so to speak, in the second imposition. First the names of the first imposition received the name 'name' as a common appellation, and then they were divided into 'nouns', 'verbs' and so on.

37 Varro, De L L 8, 1 Ut propago ommis natura secunda, quod prius allud rectum. unde ea, sic declinata llaque declinatur in verbis reclum homo, obliquim hominis, quod declimatum a recto

${ }^{38}$ For far Varro's propago; for asl origo and a word radix to be supposed from the use of propago and the simile of the tree The concept of a root in words is also found in Indian grammar, so that the likeness is hardly conclusıve (cf e g Brough, 1951, on the sphota-theory). Cf. Barwick, 1957, 29-33

39 For the crileria latımiatıs and the $u s \bar{u} /$ an-nahn above, chapter IV

40 b. Gın Has. 2, 42, 9-12 [A 105]

41 The analogical element is called declimario nuturalis, and the anomalous element declinano voluntaria, Varro, De L L 8, 21-3. 
This theory is explained in only a few texts. ${ }^{42}$ Ammonios tells us: 'Let it, therefore, be known that nature, realizing that this animal (sc. man) was to be a social animal, gave it a voice, so that it would be able to communicate its own thoughts to others by that means. And men came together and agreed with each other to call this for instance "wood", and that "stone" ... According to this way of indicating things all words were invented. Their second activity was to observe that some words could be construed with an article, though not with a tense-these were called "nouns"-, and that other words could be construed with tenses, though not with an article-these are the verbs'. ${ }^{43}$ In Latin grammar the same theory is found with Charisius: 'The Latin tongue, born at the same time as the people of its civilization, satisfied their needs of signifying and of understanding what was said. Afterwards, however, it (sc. the Latin tongue) was examıned by experts in the course of time, and it was tamed by the observations of our brilliant minds. While a few of its parts still did not fit in with the norms of speech, it let itself be ruled by grammatical rules and it made that old licence of speech subordinate to reason' ${ }^{44}$

This chronological account of the origin of two logical levels of speech was later to become a logical distinction between the same two levels, but in a synchronic frame, for the first time explicitly in Augustinus' dialogue De Magistro. Augustinus distinguishes between words that signify words (e.g. nomen, verbum, and so on), and words that signify things (e.g. homo, flumen): 'I observe that the word nomen and these four words (sc. Romulus, Roma, fluvius, virtus), to which we applied the signification of (nomen), differ in that the former is the audible sign of audible signs, whereas the latter words, audible signs though they are, are the signs of objects, not of signs'. ${ }^{45}$

42 Pinborg, 1961, 136-8, 1967, 45-6

43 Amm comment in Aristot cat ed Busse, pp 11-2 [G62], of id comment in Aristol de interpret ed Busse. 10,4 sqq, dlmost the same theory in Porphyrios, comment in Aristor cat ed Busse. pp 57-8 An dmusing practical example scholia D T $31,24 \mathrm{squ}$

44 Char 62, 2-8 Latmus vero sermo cum tpso homine civitats suae natus stgmificandis intellegundisque quae diceret praestitut Sed postquam plane supervementibus saeculss accept artifices et sollertiac nostrac observatiomitus captus est, paucis admodum partubus orationis normae suae dissentienubus, regendum se regulae tradidt et illam loquendt licentiam serviluti rationıs addirit On this passage Fehling, 1956, 222 sqq, especially pp 233-5 with the reconstruction of the prototype of this text, cf also Varro, De L L 8, 3, on the reason for the introduction of declension into speech it helped people to cover the overwhelming amount of ideas with relatively few words

45 Pinborg, 1967, 46, Coseriu, 1970, 110-4 It seems exaggerated to call Augustınus 
Returning to Arabic sources, we find that Arabic scholars operate with the same distinction between object speech and metalanguage. They were aware of the difference between two logical levels of language, between names and the names of names. For instance, Rāzì: 'Know that words are most of all expressions for things. These things may be words or something else. Words, as e.g. "noun", "verb", "particle", because each of these three words denotes something that is a word in itself; something else, like "stone", "heaven", "earth" '.46 We may also refer to the passage from Ibn Ginnīs ' $\underline{H} a s ̣ a$ ' iṣ' quoted above ${ }^{47}$ with its distinction between the object sword and the word 's-w-o-r-d-'. The most explicit reference to this doctrine is found in Gazzāli who says: 'We say that words are an expression by means of articulated sounds, invented by man's will, for the signification of individual objects. They are divided into those words that were invented primarily, and those words that were invented secondarily. Those words that were invented primarily are e.g. "heaven", "tree", and so on; those words that were invented secondarily are e.g. "noun", "verb", "particle", "imperative", "negation", "imperfect", 48 According to Gazzālī, there is even a third imposition, namely when we are dividing nouns into various sub-categories and so forth.

We should also point to the logical distinction between the first and the second intention, used in treatises on logic' 'wo man von einer ersten und zweiten intentio spricht, je nachdem ob sich das Denken unmittelbar auf die besonderen Dinge oder auf die allgemeinen Begriffe von den Dingen bezieht'. ${ }^{49}$ This theory was developed by Ibn Sīnā and we know it had an enormous influence on Medieval scholastic grammar, where it formed the basis for all theories of language. ${ }^{50}$

Apart from these testimonies we also have an explicit reference to the doctrine of the two impositions in the context of an Aristotelian commentary, namely in al-Hasan ibn Suwār's notes on the text of the

the 'Wegbereiter der supposillones-Lehre' (Coseriu, o c. 105): surely, Ammonios c s represent a tradition that is independent from the De Magrstro For Augustinus also. de Rıjk. 1968

46 Ràzi, Mal 2, 96, 12-4 [A 106].

47 b Gin. Has 3, 31, 5-10, cf above, chapter VIII, note 41 .

48 Gazz Asmā', 5, 19-23 [A 107]

49 Gatjc, 1965, 281; of van den Bergh, 1954, 2, $111 \mathrm{Kw}$ Gyeke draws the attention to an ambigutty in the use of prima intemtio ef secunda mtemto, (Gyeke, 1971)

${ }^{50}$ Pinborg, 1967, 37 sqq Note the importance of Gazzâli’s doctrine of the three modes of being, as compared with the Medieval modt essend, mtelligend et significandi 
Categoriae, which are based on a Greek commentary, possibly by Ammonios. ${ }^{51}$ Ibn Suwār says: "We say "in the first imposition" to distinguish between expressions from the first and from the second imposition, because the expressions from the first imposition are the names ... that have been imposed on the objects primarily, and that have become marks and signs serving as a general denomination for them, for instance when we call this "silver" and that "copper", and that "gold": in short, all expressions that point at one single meaning. The expressions from the second imposition are those that we have separated from the expressions of the first imposition. Their meaning is that we call, for instance, every word that signifies a definite meaning without time ... ("noun"), and every word that signifies a meaning as well as time "verb" ... These are the expressions of the second imposition; they owe their names to the fact that we invented them after the expressions of the first category'. 52 We assume that Ammonios' commentary on the Categoriae was the source of the Arabic theories about the two impositions.

As for the Arabic grammarians, they were only interested in this doctrine in so far as they wanted to use it for the solution of the problem of which part of speech came first chronologically, and whether there ever existed a stage of language in which there was speech without declension. The majority of the grammarians decided that the original Arabic language did probably possess declension, because of the wisdom of the ancient Arabs, who introduced declension into speech in order to prevent ambiguities and doubts about the meaning of a sentence. ${ }^{53}$ The old distinction natura vs. ars becomes here once again pejorative with regard to the 'artificial' element, since according to general opinion, the original language was pure and undefiled, but later generations corrupted it by their frequent use of words (ka!̣ al-isti māl). ${ }^{54}$ Some grammarians, however, asserted that the original language did not possess declension, which was added only later by an effort of reason. ${ }^{55}$ Anyway, we may conclude that in

$51 \mathrm{Cr}$ chapter VI, note 38

52 b Suwār, 361, 8-16 [A 108]

${ }^{3} 3$ b Gın Has 2, 31, 7 - 32, 5: the doctrine of Abū 'l-Hasan al-Aháfas.

s4 Ib 2, 29, 4 sqq, the same doctrine with Ibn Hazm, Arnaldez, 1956, 45-6.

is $\mathrm{Cf}$ the discussion in Zağğ Id 67-9. Accordıng to Zağğāă speech and declensıon always coexisted; nevertheless it is possible to say that nouns are prior to verbs, when we make a hıerarchıcal classıficatıon, not a chronological one Zağğāg̀i admits that some people have a different opinion (Id. 68 ult $-69,2$ ). 
technical grammar the original distinction lost its logical flavour, and turned itself into a practical question. ${ }^{56}$

Another important source for the Arabs was the Cratylus. We know that Plato's dialogue about the 'rightness' (orthótès) of the words (i.e. about their value for our knowledge of the essence of the things designated by them) was discussed in the Arabic world. That they understood correctly what the Cratylus was all about may be deduced from Fāräbìs explanation of the character of that dialogue in his Falsafat Aflätūn: 'Thereafter, he (sc. Plato) investigates whether this art (sc. the art of happiness) is the art of the science of language, and whether man, if he has a complete knowledge of the words which signify meanings, in so far as they signify something for the majority of the nation to which that language belongs, and if he investigates those words and knows them according to the methods of the scholars of that language, whether in that case man would have acquired a complete knowledge of the essence of things $\ldots{ }^{57}$ It will be noted that for Fārābi the question is not who created speech, but what is the value of speech for the understanding of objects in the outer world.

More data are provided by the writings of Aristotle. According to him, speech is the result of an agreement (sunthèke) among men, and it has therefore an arbitrary nature: ${ }^{58}$ we cannot judge from the form of the words what is the essence of the things designated. ${ }^{59}$ Aristotle,

56 This practical question also shows that Arabic grammarians were aware of a certain development in speech As a matter of fact, this dynamic aspect of speech was a controversial issue in another respect, namely that of the creation of new words (e.g. in the language of the artisans, Loucel, 1963, 267-8); cf. Kopf, 1956, 40-5 Fleisch's remark (1961, 17, n. 1) that Arabic theories about language lack a dynamic view does not seem altogether justified. Those grammarians who occupied themselves with the origin of speech, certainly made room for a development in specch according to the Stoic doctrine of ars-natura - usus Change of language as a result of corruption of the old habits was a commonplace in almost every work about correct language, $\mathrm{c} g$. $\mathrm{b}$. Gin. Has. 2, 29, 1-6: here, Ibn Ginni asserts that the Bedouns did not change their speech, but with the introduction of civilization people deviated from the iräb (= 'declensıon' or arabitas??) of pure speech; cf. also Fück, 1955², pp. 44 sqq. et passım; Zubaidi ap. Loucel, 1963, 206 (19); also b. Gin. Has., 2, S sqq ; Ibn Hazm's views on the changes of language : Ihk. 1, 30, 8-23.

57 Far Fals Afl. 7, 1-8 [A 109]. The Cratylus in Arabic: b a Ușaibia, 1, 201, 5; Kraus, 1942, 2, 238, n. 2; Bergsträsser, 1913, 50. It may be added that the Cratylus was also known in Syriac literature, namely in Jacob of Edessa's introduction to his letter on orthography, and in a scholion about the names of God, which also exists in an Arabic translation, of Nestle, 1878, especially p. 502.

58 E.g. Aristot. de interpret. 16 a $19 ; 16$ a 26-9; soph. el. 165 a 7 ; sens 437 a 13-5.

39 That words have no epistemological value is evident from Arıstotle's remark, de 
though, was not interested in the genetic problem of the origin of speech : for him it was important to determine the functional value of the words and the way they function in actual communication; the important thing is that words are conventional, not that they are the result of a convention. ${ }^{60}$ Later generations were more interested in another aspect of the matter: the creation of speech by the first communities of men (sunthèkè, thésis). The term thésis must have been taken over rather early by the Arabs, because we find the Arabic equivalent wad right at the beginning of Arabic grammar. ${ }^{61}$ The Aristotelian point of view was transmitted at a later time, first through the commentaries on the De Interpretatione, which were translated into Arabic (particularly the commentary of Ammonios in the notes of Ibn Suwār), and later through the indigenous commentaries, of which Fārābì's Sarh al-ibära shows the best understanding of the original problem. ${ }^{62}$ In grammatical discussions, however, we are almost always confronted with the question of the origin of speech: is it a creation of Allāh, or a product of human creativity? This is the problem as it is discussed by Ibn Ginnī, Suyūțī, and others. ${ }^{63}$

interpret. 17 a 1-2: 'Every sentence (lógos) is meanıngful, not as an instrument (órganon), but, as we have said, by agreement' [G63]. The word organon clearly refers to the Crayylus, where Sokrates calls a word an órganon didaskalikòn kai diakriıkón (Plat Crat $388 \mathrm{~B}$; of Steinthal, $\left.1890^{2}, 1,186-7\right)$-although, according to Ammonios, Aristotle refers here to another thesis, namely that a sentence is a natural instrument of speech, just as the human faculty of speech. Amm. comment. in Aristot de interpret 62,21 sqq. ed Busse

${ }^{60}$ Arıstotle does not use the dative sunthèkèi, but the expression kata sunthèkèn, which Coserıu, 1970, 65-9, interprets as 'traditionell', 'historisch-moliviert' According to him, Aristotle's purpose is not to define the genetic connection between words and thıngs, but to establısh the functioning of words in actual speech Cᄃ. also ib, p. 82 and pp. $90-5$

${ }^{1} \mathrm{Cf}$. the expression wudia ala (to have been invented for a cerlaın meaning), e.g Sib. Kit. I, 186, 8 According to Weiss, 1966, 38-40, the original meaning of wad is 'givenness of language'; this meanıng gradually gave way to the meanıng 'establishment of language', 'origin of speech' (wad al-lugia); in his view, the Mu'tazilites were the first to use the word in the sense of 'conventional establishment'. It seems, however, that wad did not denote the givenness of the relation between expressions and meanings before the introduction of the treatises on the wad' al-luga by al-Iği ( 14 th/8th century), cf also Weiss, 1b., 52-3, 78, where it is stated that in the sense of 'conventionality' the term used is muwäda'a, not wad'

$62 \mathrm{C}$. especially Far Sarh, 50, 1-51, 7 for the different uses of terms such as 'nature' $\left(1 a b^{\prime}\right)$ Fārābi also uses the Arabıc translation of the Arstotelian nómos, namely šaria (ib. 27, 13;20)

63 Loucel, 1963-4. 
Returning to the opinion of the Mu'tazila, we must note that they need not oppose the creation of speech by Allāh on principle, since it could fit perfectly well in their philosophy. On the other hand, a Mu'tazilite could hardly accept the existence of a necessary relation between words and things, created by Allāh or invented by men, because this would impair human judgment and thereby human liberty to choose by his own will. 'They (sc. the Mu'tazila) reason thus: if the knowledge about an attribute is necessary (darūri), then the knowledge about the thing to which it is assigned must be necessary, too. If Allāh the Lofty had created this knowledge in the heart of the wise, by determining such-and-such a word for such-and-such a meaning, it would thence follow that knowledge of Allāh would be necessary. This is contradicted by the reality of the task He imposes upon us (sc. the task to believe in Him)' ${ }^{64}$ The result of this reasoning is a general belief among the Mutazilites that language is a product of a conventional agreement (isțiläh, muwāda $a$ ) among men. ${ }^{65}$ The theoretical possibility remains, though, that men made the first language, and that, after that, Allah taught them through this language the rest of the languages - which is actually the opinion of 'Abd al-Ğabbār's teacher, Abū Hāšim (d. 933/321): ${ }^{66}$ note once again that the Mu'tazila is not opposed on principle to the revelation of a language by Allāh. ${ }^{67}$

However this may be, words were generally regarded by the $\mathrm{Mu}$ 'tazilites as arbitrary signs (simät), which are used accidentally for certain objects. The word 'sign' (sima) is connected with the problem of the etymology of the word ism. This problem is dealt with by Ibn alAnbārī in the first question of the Inșâf.$^{68}$ Ibn al-Anbārì tells us that the Bașrians-probably represented by al-Mubarrad ${ }^{69}$-derived the word ism from the radicals $s-m-w$, c.q. from the word sumuww (height), for words are an expression of nominata below them, and

64 Rāzí, Maf. 1, 23, 1-6 [A 110], cf Suy. Muzh. 1, 12-3

os 'A bd al-Gabbār, Mugnī, 7, 183, 9-12. The fact remains that at least one Mu'tazilite held that the relation between words and things is completely necessary This is the opinıon of 'Abbād ıbn Sulaımān (d 844/230), ç. Mahdi, 1970, 52, n. 2 and above, chapter II, n. 6l. In this case, however, the relation is considered as being natural (imposed by nature) and not imposed by Allāh As for the implications of this identity of 'meaning' and 'necessary cause', of below, chapler X, note 63.

${ }^{66}$ Rāzì, Mar. 2, 201, 15-6, 'Abd al-Gabbār, Mutašābih, 1, pp. 82-3.

67 Mahdi, 1970, 53, n. 5.

64 b. Anb Ins. 1, $17-6,10$; cf Id. Asr. 3, 3-5, 18, Lısān, 19, 126, s.v. s-m-u; b. Ya'ìs, 26, $21-27,15$.

${ }^{69}$ Mub ap. b. Fār Sāh. 57, 17-8. 
they are therefore elevated above them. ${ }^{70}$ The Küfans, on the other hand, derive the word ism from the radicals $w-s-m$, c.q. from the words sima (sign) and wasm (stigma): "The word is a sign which is placed upon the thing and by which the thing is distinguished'. ${ }^{11}$ Ibn al-Anbāri himself agrees with the explanation of the Küfans, although he rejects the etymology proposed by them. ${ }^{72}$

Sima is an arbitrary sign, which serves to distinguish between different nominata in a conventional way. ${ }^{73}$ The opposite interpretation of $i s m$ as derived from the radicals $s-m-w$, considers words as something connected with the things designated, and given to them for a special reason, whether by Allāh, or by nature. There is indeed a text where sima is used by the advocates of a conventional theory about the origin of speech; Ibn Ginni tells us: 'For (according to them) everything happened as if two, three, or more scholars should come together and should want to designate known objects. In order to do so they would choose for every object a sign and an expression (sima wa-lafz). By recalling this sign you would know the object it designates, and distinguish between it and other objects, and you would not need to have the object present, if this word was used'. ${ }^{74} \mathrm{~A}$ connection between the Mutazila and the etymology ism - sima is reported by Bāqillāni. ${ }^{75}$

Considering these facts, and the fact that Weil thinks that this problem arose rather late, ${ }^{76}$ we suppose that the original discussion about the true etymology of the word ism was later translated in terms of the discussion about the origin and the nature of speech. The

${ }^{70} \mathrm{Cf}$ the expression al-musammayāt tahıahä whıch is used in this context. The idea that words are elevated above the nominata is ridiculed by Ibn Hazm (Kıtäh al-fisal, Cairo, 1321 A.H., 5, 29 the fact that we use words like 'dog, pig, idolatry, etc.' shows that not every word is as elevated as the Basrians suppose!). Cf Arnaldez, 1956, 85

${ }^{71} \mathrm{Ta}$ lab ap b. Anb. Ins 2, 4 [A 111]; as a synonym for sima the term alämo is used, ıb. 2, 1; 2 Cf. Abū 'l-'Abbās (probably Ta'lab), Lisān, 14, 401, l.6 from below. 'The noun is a description and a sign which is placed upon the object in order to make it known (by that sign)' [A 112].

72 Just as Ibn Fārıs and 'Ukbarì do b. Fār. Sāh, p. 57; also 'Ukb Mas , 65-6: ism means the same as alama, but this does not imply that $\iota \mathrm{sm}$ is derived from wasm, sima.

${ }^{73}$ Or between their varıous grammatical functions sıma as a grammatical sign, e.g Zağğ Id. 99, 6; cl. b Gin. Has. 2, 355, 16 mausūm bl-'l-ĭrāb Ibn Ginnì uses the term with this meaning of 'grammatıcal sign' also ib. 2, 300, 4; as a synonym for 'alam-cf. aläma above, note $71-$ : ib, 2, 316, 12 sqq.

74 b Gin. Has 1, 44, 3-6 [A 113]; cf Loucel, 1963, 267 (36).

${ }^{9}$ Bãq Tamh 225-7, on the theologıcal implications of the etymology of ism. van Ess, 1965, 117.

76 Well, 1913, 121 
Bașrian etymology in Ibn al-Anbārī's account represents the opinion that words are the expression of the true nature of things, whereas Küfan etymology grants words only a conventional, purely arbitrary meaning. It is not clear, however, if these consequences of the two etymologies were already drawn at the time of al-Mubarrad (the representative of the Bașrian theory in Ibn al-Anbārī's account) and $\underline{T} a^{\prime} l a b$, or if they are the result of later theorizing influenced by the Mu'tazilite school.

The orthodox point of view in its most extreme form attributes the creation of each and every word to Allāh Himself. This is mostly based on the Qur'ānic affirmation that Allāh taught Adam all names. ${ }^{77}$ There are precedents for this belief in Greek patristic and theological literature, where we can find the tendency not to acknowledge any activity of man in the creation of words. ${ }^{78}$ On the other hand, for a follower of orthodoxy it was also possible to combine the two doctrines - creation of speech by Allāh and human activity and suppose an agreement among men resulting in the invention of speech (which is then arbitrary, of course), but at the same time to state that this agreement first needed an inspiration from Allāh. There is, to be sure, a difference between this theory and the one we reported above from Abū Hāšim, but the result is virtually the same. In fact, we even find a Mu'tazilite who held this opinion, namely Abū Isḥāq al-Isfarā'inì (d. 1027/418). ${ }^{79}$ It was also shared by al-Guwainī, the Imām al-Haramaini, Gazzālī's teacher (d. 1085/478). ${ }^{80}$ If instead of 'Allāh' we read the word 'nature' in these combinations of the two doctrines, we have here a faint echo of the Stoic doctrine, even more so if we keep in mind that the original controversy was not about the origin of speech, but about the value of the words for the understanding of the essence of the things designated by them. Interpreted in this way, the same combination is found in Ibn Ginni, who states that there are two kinds of words, the first sort not being liable to grammatical analogy (qiyass) (i.e. the original, natural words), whereas the second one is (i.e. the derived words which are classified by rules and grammar) ${ }^{81}$ Here we are close again to the doctrine of the two impositions.

77 Qur’ān, 2/31. e g. b Fār Sāh 5-8, cf Loucel, 1963, 255 sqq. (24 sqq ), b Gin Has. 1,40

7* Cr Daniélou, 1956, 422-3

${ }^{74}$ Suy Muzh 13,8 sqq

80 Ib 14, 5 sqq Gazzäli mentions the opinion of his tcacher as onc of the three possible solutions to the problem, in almost the same words as Suyūti. Gazz Mustas$\sqrt{a}, 145,16-7 \mathrm{Cf}$ Asin Palacios. 1939, 266, Cabanelas, 1956, 44-5

1 1 Gin Has. 2, 42, 9-12, ef above. nole 40 


\section{THE STOIC COMPONENT IN THE THEORY OF MEANING}

'How could we say that someone is speaking without thınkıng, if speech were really the same as thought " I

We have spoken above ${ }^{2}$ about the so-called voie diffuse, by which Greek doctrines filtered through to the Arabic world, and we have also seen that there was another way, the voie érudite, constituted by the translations of Greek learned works, which, in a more organized way, acquainted the Arabs with Greek doctrines during the period leading up to and coinciding with the bloom of the Baghdad university. ${ }^{3}$ It has been recognized lately that there are a considerable number of traces of Stoic doctrine in Islamic culture. ${ }^{4}$ Many of these can be traced back to general philosophical literature (such as the translations of the commentaries on Aristotle, pseudo-Ploutarchos' Placita Philosophorum, etc.). But there are also such as cannot be accounted for in this way. In such cases we must resort to the hypothesis of a voie diffuse, which found its origin in the still Hellenistic environment of the conquered territories. We have tried to show in the preceding chapters that a number of elements in Arabic grammar came to the Arabs by this voie diffuse, i.e. through contact with living Greek grammar. Some of these elements can be traced back to the Stoic roots within this Greek grammar (e.g. Zağğāğı̀ss definition of the noun ${ }^{5}$ the paradigms for the nouns faras and insän (or rağul) ${ }^{6}$ the distinction between proper nouns and common nouns; ${ }^{7}$ the Stoic division of sounds $;{ }^{8}$ the Stoic doctrine of phonetic changes; ${ }^{9}$ the concept of verbal tense ${ }^{10}$ ). Other elements must be the result of the

'A bd al-Gabbār. Mugni, 7, 18, 13-4 [A 114]

2 Cf above, chapler I. note 45

For this period Hittı. 1968', 306-16

${ }^{4} \mathrm{E}$ g Jadaane, 1968

5 Cf above, chapter III B, note 36

- Cr above, chapler III A, note 12

${ }^{7} \mathrm{Cr}$ above, chapter III B, note 7

- Cf above, chapter II

- $\mathrm{Cr}$ above. chapler II. note 44

${ }^{10} \mathrm{Cr}$ above, chapter III C 
influence which translations of Greek philosophical writings exercised upon Islamic philosophy (e.g. the definition of 'definition'; ${ }^{11}$ the notion of 'predicate'; ${ }^{12}$ the Stoic conception of sound $;{ }^{13}$ the notion of 'something'; ${ }^{14}$ the concept of time ${ }^{15}$ ). In this chapter we want to discuss the part the Stoics played in the movement of ideas with regard to one important problem of Stoic logic, namely the connection between thinking and speaking, i.e. the problem of meaning.

To the logical part of Stoic philosophy belong dialectic (the knowledge of truth and falsity), and rhetoric (the knowledge of eloquence). The science of dialectic is divided by Chrysippos into two parts: the signifying part (sèmainonta) and the signified part (sèmainómena). ${ }^{16}$ This distinction between things which are signified and things which signify, between meaning and sound, and in connection with it, the distinction between thinking and speaking, i.e. between concept and meaning, is essential for Stoic logic. It is true that Aristotle already speaks about the difference between sound and meaning, ${ }^{17}$ but in his view meaning is identical with the concept formed in the thinking mind. His distinction between an outer speech (éxô lógos) and a speech in the mind (lógos en tèi psuchèi) ${ }^{18}$ must be understood in the sense

$11 \mathrm{Cr}$ above, chapter VII, note 8.

$12 \mathrm{Cr}$ above. chapter III C

${ }^{13} \mathrm{Cr}$ above, chapter II, note 37

14 CS above. chapter VII, note 33.

${ }^{15} \mathrm{CS}$ above, chapter III C

${ }^{16}$ Diog Lacrt 7, 41-2 = SVF, 2, 48: 'Some people say that the logical part (sc of philosophy) is divided into two sciences, namely into rhetoric and dialectic ., and (they say) that rhetoric is the science of speaking well about the things at issue, and that dialectic is the science of discussing correctly about the things in question and answer That is the reason why they define it (sc. dialectic) thus it is the science of truth and falsehood and that which is neither' [G64]. Diog Laert 7. $62=$ SVF 2. 122 : 'Dialectic. according to Poseidonios. is the science of truth and falsehood and that which is nesther. it happens to deal with that which signilies and that which is signified, as Chrysippos says' [G 65].

17 E.g Aristot rhet. 1405 b 6-8. 'The beauty of a word, as Likumnios pul 11. lies In the sounds or in the meaning. just as the ugliness of a word' [G 66].

is This difference is introduced anal post, $76 \mathrm{~b} 247$. The argumentation is not connected with the outer speech, but with the speech in the mind, because neither is a syllogism (sc connected with outer speech) For it is always possible to object aganst outer speech, but not always against inner speech [G67] The same distinction between two sorts of specch occurs as early as Plato. Soph 263. who plays with the words logos and dialogos, just as Latın authors later used the words ratıo and orato (cf also Theaet $189 \mathrm{E}-190 \mathrm{~A})$ This is the source of the distinction between speech-in-sound and speech-in-thought, later designated with the words prophorikis logos and endiáthetos logos, respectively Pohlenz has shown $(1939,191-8)$ that this distinction, though resembling to a certain degree the Stoic theory, cannot be attributed to the older Stoa What fell normally under the endiathetos logos (cf SVF 2,135) was dealt with by the Stoa 
of his theory of meaning, which was later to become the basis for almost every theory of meaning in the Western world during the Middle Ages: 'What is in speech is a symbol of what is in the mind, and what is written is a symbol of what is in speech. Just as the letters are not the same for everyone, neither are the sounds. The emotions of the mind, however, of which these (sc. the sounds) are the immediate signs, are the same for everyone, and the things (sc. in the outer world) of which these (sc. the emotions in the mind) are the images, likewise'. ${ }^{19}$ It will be clear that this tripartition 'things in the outer world'-'concepts = meanings'-'sounds' is different from the Stoic doctrine, which distinguishes most carefully between concept and meaning. But when even Steinthal tells us that the Stoics themselves did not understand their own innovation, and that in practice they confused their newly discovered 'meaning' with the concept or the thing in the outer world designated by it, ${ }^{20}$ it seems necessary to consult the sources again. We must keep in mind, of course, that so revolutionary an innovation could very easily be misunderstood by later authors, but the fact that they confused it with the traditional point of view in their accounts ${ }^{21}$ does not prove that even the Stoics themselves were inconsistent in their own doctrine.

under the hedding semanomena In other words, the Stoics know about the distinction, but only in so far ds they distinguish strictly between thinking and speaking, and not ds a distinction between the physical and the psychical side of speech One could say that the semainomena are identical with, or have the sdme content as the endiathelos logos in d system which does not distınguish between thoughts and meaning Porphyrios dttributes the distinction between the prophorikos lógos and the endiánetos logos explicitly to the Stoa (de abstın 3,2-17), which could be interpreted as follows that the Stoa did use the distinction but in the sense of an opposition between the thoughts (ennotal, SVF 2, 83) = endiathetos logos and the sounds together with their meaning (phone + pragmata $)=$ prophorikos logos This opposition was later understood as a distinction between inner and outer speech

19 Aristot de interprel 16 a 3-8 [G 68] For d discussion about this difficult text Steinthal. $1890^{2}, 1,185$ sqq , he translates 'Dic Sprache ist Zeichen fur die Erregungen der Seele, und das Geschricbene fur jene, und wie die Buchstaben nicht uber all dieselben sind, so duch nicht die Laute Die Erregungen der Seele dagegen, von denen letztere zunachst Zeichen sind, sind dieselben uberall, und die Dinge, von denen jene (die Seeleneindrucke) Abbilder sind, sind ebenfalls dieselben ${ }^{*}$ Cf also Pinborg, 1967, 36, who quotes Boethius' iranslation into Ldtin of this text, through which it became known to Medieval scholiasts in the Western world, also Pinborg. 1972, p 30-1 Cr also Ackrill, 1963, pp 113-5, Kretzmann. 1974, Coseriu. 1970, 65-70, Ldrkın. 1971, 21 sq9

20 Stemthal, $1890^{2}, 1,288$ 'Es scheint auch kaum, als waren die Stolker im Stande gewesen. das Wesen desselben (sc of the lekton) genau anzugeben und festzuhalten, es schmilzt thnen doch bald mit dem noema, bald mit dem tunchánon zusammen'

${ }^{21} \mathrm{Cr}$ below, note 52 
The text which, unwittingly, gives us the clearest insight into the real meaning of the Stoic doctrine, and which at the same time betrays the reason for the innovation-perhaps even more so than the intellectual arguments mentioned by Sextus Empiricus and Augustinus-is the remark of an ignorant scholiast on Homer, who observes on Iliad B 349: 'Lie (pseûdos): instead of "false" (pseudès). Such things are called by the Stoics lektá, which are used instead of other words with regard to the signification'. ${ }^{22}$ The sense of this is clear: in the verse from the Iliad there is a discrepancy between the meaning of what is said and what we think when we say it, and this is, according to the scholiast, the famous Stoic lekton-he does not, of course, understand the frame-work within which the lekton operates in the Stoic doctrine. But it must have been this discrepancy which led Chrysippos to write about anomaly, i.e. about the fact that similar things are indicated by different words and different things by similar words, ${ }^{23}$ and it must have been this discrepancy which led the Stoics to distinguish between meaning and thought-possibly as a result of their non-Greek background, which made them more sensitive to such discrepancies than the Greeks themselves. ${ }^{24}$ The same intention is evident in a fragment from Ploutarchos: 'They themselves (sc. the Stoics) say that one who forbids something says something, forbids something else, and commands something else again. For when you say "Do not steal!", you say those words "Do not Steal!", you forbid the stealing, and you command not to steal'. ${ }^{25}$ Here we find the distinction between the signifying sounds (the words 'Do not steal!'), the concept in the mind (the prohibition to steal), and the linguistic meaning (a negative imperative of the verb 'to steal').

This implicit distinction is explained in the more 'official' texts, like for instance in a fragment from Ammonios, who speaks about

22 SVF 2, 169 [G 69]

23 Varro De L L. 9, 1 . .. quod et Chrysippus de inaequahilitate cum scribit sermonis propositum habet osfendere similes res dissimilibus verhis et dissimiles similibus esse vocabulis notatas ... Mette has explained this text correctly with the help of a fragment from Simplikios $(1952,12)$ : 'Es handelt sıch um ein formallogisches, kein im eigentlichen Sinne sprachliches Problem'; cf Barwıck, 1957, 53-4; Gentınetta, 1961, 107-8; 114 sqq , the fragment from Simplikios: SVF 2, 177.

24 For the non-Greek background of many Stoics: Pohlenz, 1939, 157 We may also point to Chrysippos' interest in figurative speech, which was probably for him more figurative than for native Greek speakers; cf. SVF 2, 259, 28; 260, 39, 261, 16, 263, 3; 263,9, SVF $3,125,12$.

25 SVF 2, 171 [G 70]; cf. maybe also the quotation from Ps -Apuleius, SVF 2, 204 a, and van den Bergh, 1954, 2, 4. 
the difference between Aristotle and the Stoa on this point, although he does not seem to be too well informed: 'By these words (sc. the text we quoted above from the De Interpretatione), Aristotle teaches us what is principally and immediately signified by them (sc. the sounds), namely the concepts, and through them the things, and also, that we cannot suppose something between the concept and the things, as the Stoics did, calling it lektón'. ${ }^{26}$ This question-whether meaning is something apart from thought or not-rormed in the Middle Ages one of the most important issues in the discussions between the Modists, who held the first opinion, and the Nominalists, who held the second: 'Die Frage ob die Bedeutungen der Wörter und der Sätze irgendeine Existenzform haben, oder ob es nur die Wörter und ihren willkürlichen Gebrauch gibt, gehört von jeher zu den am heissesten umstrittenen Grundfragen dieser Disziplin'.27.

A systematic discussion of the elements of the Stoic theory is provided by Sextus Empiricus in connection with the problem whether we can find truth and falsity in the sounds, in the meaning, or in the activity of the mind: 'The people of the Stoa say that three elements are connected with each other: that which is signified (sèmainómenon), that which signifies (semainon), and the incidental thing (tunchánon). Of these elements the second one is the sound, for instance $d-i-\hat{o}-n$, the first one the meaning (prâgma) itself, which is indicated by it, and which we grasp in its correlation with our understanding, whereas the barbarians do not understand it, even though they hear the sounds. The incidental thing is that which is in the outer world, in

26 Amm comm in Aristol de interpret 17, 24, ed Busse = SVF 2, 168 [G71] It 1s, of course, true that Ammonios' statement that Stolc lektá are something intermediate between thoughts (concepts) and objects, is not entırely correct-he ought to have said that they are something intermediate between sounds and concepts (Long, 1971, 81) On the other hand, we may perhaps understand this statement in a less technical way ('something apart from thoughts and objects') Long's equation of the triad logikè phantasia-lekton-phantusthén with the trad semeion-lektón-lunchánon (ib 83) cannot be accepted Objects cause an impression, a representation in the mind (phantasia), on a linguistic level objects are represented by the linguistic entity soundmeaning, some representations correspond to, correlate with such meanıngs, and are therefore called rational (expressive, communicable) representations It is incorrect to assert that 'the words which an auditor receives must be the utterance of the speaker's rational presentation' (Long, ib ) The hearer receives sounds emitted by a speaker's phônétıkón, one of the faculties or the parts of the mind!

27 Pinborg, 1967, 9, who follows this question up to modern times 
this case Dion himself.$^{28}$ We do not agree with Steinthal that in this case meaning is confused with thought. ${ }^{29}$

It seems that lektón was not originally a technical term, but an expression which indicated the principal characteristic of the 'things' (prágmata, in the Stoic sense of 'meaning'), namely that they are used in speech, and that they are the meaning of the actual sounds. This non-technical use appears in the following passages: 'Sounds are uttered, but the meanings (prágmata) are said; that is precisely the reason why they are also (called) lektá'; ${ }^{30}$ and: 'Every meaning (lektón) must be said, whence it obtained this name'. ${ }^{31}$

Augustinus, in the fifth chapter of his De dialectica ${ }^{32}$ sums up in a similar way the elements which constitute meaning. He says: 'A word (verbum $)^{33}$ is a sign of any given thing which can be understood by a hearer, if it is uttered by a speaker. A thing (res) is everything which can be felt or understood or what is hidden ... Everything in the word which is not perceived by the ears, but by the mind, and which is deposited in the mind, is called dicibile ${ }^{34}$

${ }^{2 \mathrm{~B}}$ Sext. Emp adv math 8, $11=$ SVF 2, 166 [G 72]

29 Steinthal $\left(1890^{2}, 1,289\right)$, who says that in this case the lekion is confused with the nóma The word parhuphistamenon is not to be translated as 'das im Verstande vorhandene", but it is to be understood as 'coexisting with and correlating with what is in the mind'; for the meaning of the word, cf. Liddell/Scott, s.v. (to the loci quoted there add. Apoll Dysk synt passim, cf Schneider's index, s.v.); Long, 1971, 77, 80, 84 ; 108 , note 25,110 , nole 71

${ }^{30}$ SVF 3, 213, 22-3, a quotation from the Téchne of Diogenes the Babylonian [G 73]

31 Sext Emp adv math 8,80= SVF 2, 167 [G74] One wonders whether the term legómena, which occurs in the title of several Stoic works, might not mean the same thing, viz. meaning in so far as it is expressed in what is said, cf. a book of Chrysippos Perì tôn stoucheiôn toú lógou kai tôn legoménôn, SVF 2, 6, 17, and another one Perì tès suntáx'ôs tôn legoménôn, SVF 2, 6, 18, especially the tutle of a book of Anupatros Peri léxeôs kai tôn legoménôn, SVF 3, 247, 25-6 (léxis = phôné; legómena = lekıá, prágmata?). Cr. the term legomenon used by the Aristotelian commentators, Long, 1971, 107 , n 13,108, n. 23

32 This source had been already used by Schmidt for his reconstruction of the Stoic doctrıne, 1839, 54-5, cf. also Barwıck, 1957, 8-28; de Rıjk, 1968; Coseriu, 1970, 105-23.

33 Verbum is used by Augustinus in two senses. it can mean 'the phonetic shape of a word', but also 'unity of sound and meaning, lınguistıc entity', approximately in the same way as Apollonios Dyskolos uses lekion in the sense of "word in so far as it means something', cf. Schneider's index, s.v. In this sense it is equivalent to the Storc léxıs sèmantıkè, phônè sèmantıkè, cl. SVF 2, 48, 29-30;3, 213,8

34 August. dialect V 7, 6-7;8, 45. Verbum est uniuscuiusque ret signum, quod ab audiente posst intellegi, a loquente prolatum Res est quidquid vel sentthur vel intellegitur vel latet ... Quidquid autem ex verbo non aures sed animus sentt et ipso animo tenetur inclusum, dicibile vocatur. 
Several attempts have been made to give the Stoic concept of meaning its place within the logical context, ${ }^{35}$ but its value has been expressed very well by Steinthal, notwithstanding his negative attitude to the Stoic innovation: 'Das lektón ist nur das, was Aristoteles tà en tèi phônèi, hai en tèi phônèi katáphaseis kà apóphaseis nannte, und was auch er von der dóxa noch unterschied. Der Unterschied liegt nicht im Inhalt (denn die Vorstellung und das lektón haben denselben Inhalt), sondern in der Existenzweise, wie namentlich nach der Ansicht der Stoa der Fall sein musste' ${ }^{36}$ We must add, though, that in the Stoic doctrine there was a difference between the lektón and the 'Vorstellung' (nóèma), not only ontologically (non-existing lektá vs. corporeal existing noèmata ${ }^{37}$ ), but in practice as well, as we have seen for instance in the remark of the scholiast. It was precisely this difference which led the Stoics to stipulate something else, apart from the idea (nó̀ma). ${ }^{38}$

Several authors suppose a connection between the Stoic term lektón and the Arabic word maina (meaning), ${ }^{39}$ but this supposition is based exclusively on philosophical texts. One tends to forget that the first occurrence of the Arabic term was in grammatical texts, namely in Sibawaihi's Kitäb. This means that if there is any connection with the Greek term, this connection should be proved primarily through the grammatical contact between Greeks and Arabs, and not through the translations of Greek philosophical works.

In Arabic grammar, we find two pairs of words which indicate the opposite entities, sound and meaning. In the first place there are the

35 E g Chrıstensen, 1962, 44-8, Bocheńskı, 1956, 126 sqq, Mates, 19612, 11-26, Mignuccı, 1965, 88-103; Virieux-Reymond, 1941; Long, 1971, Kneale/Kneale, 1962, 139-43, Pinborg. 1972, 31-2

36 Steinthal, $1890^{2}, 1,296$

37 The incorporeity of the lekıa Sexi Emp. adv math 8, $409=$ SVF 2, 85, cf SVF 2. $170 ; 2,331,2,48,23$ and of the discussion Long, 1971, 84-90. The lektón possesses only a huphestanar, and il can only be conceived of by inference, by abstraction (kata méábasin (ina), Diog Laert 7, 53; Sext Emp. adv. math. 9, 393, Long, 1971, 109, n 54 .

${ }^{38} \mathrm{Cf}$ also Schmidl's excellent summary of the Stoic views about meaning, 1839 , 55, n 78: 'Hoc prâgma vero cave putes Stoicis fuisse arborem illam ipsam s. illud to tunchánon, in quod tu prımum incideris, neve etiam ıpsam illam visıonem s phantasian, quam arbor effecerit in anımo tuo. Utravis enım non solum ipsa arbor, verum etıam visio, quippe quae nihıl sit nisı pós échon hègemontkón, secundum Stoıcos ad res corporales pertınet sed prâgma est incorporale ıllud, quod cum tua vox s phônè alterius cuıspiam anımum attigerıt, unusquisque voci isti subesse vel intelligat vel sentiat'. Cf. Christensen, 1962, 45-6.

39 Rescher, 1966, 80, n 39; van Ess, 1970, 33; Gätje, 1965, 280 sqq ; van den Bergh, $1954,2,188$ 
words ism and musamma $\bar{a}$, which indicate the opposition between the word and the real object in the outer world denoted by that word. Sibawaihi does not use the term musammā in his Kitāb, but his name is mentioned in the discussions about the identity of ism and musam$m \bar{a}{ }^{40}$ For these two terms we find a clear parallel in Greek texts: Ammonios uses the terms ónoma and onomazómenon in his commentary on Aristotle's De Interpretatione: 'For if the name of something is the name of a nominatum, it is clear that in the absence of a nominatum the meaningless sounds are not names' ${ }^{41}$ Onomazómenon is also found in the technical vocabulary of Apollonios Dyskolos. ${ }^{42}$ In all probability this pair of words found its way into Arabic grammar and logic through the translations of Greek philosophical writings. This explains why precisely these two terms were used in the discussions about the identity of ism and musamma $\bar{a}$, which is a logical issue of a later date. We do not believe, therefore, that Sibawaihi used the term musamma $\bar{a}$, and the occurence of his name in this context must be explained in some other way. We refer to the discussion about the meaning of the term musammā as opposed to ism. ${ }^{43}$

In the second place, we have the pair lafz and maina, as the expression of the opposition between a phonetic expression and its meaning. These terms are equivalent to the current distinction in later Greek grammar between phônè (sound) and sèmainómenon (meaning). ${ }^{\mathbf{4 4}}$ The basis for this opposition is found in the Stoic theories on meaning. The Stoics made a strict distinction between the phonetic and the semantic aspect of the linguistic sign, as we have seen in the quotation from Sextus Empiricus. Semainon is the signifying, i.e. phonetic aspect (= phônè), and the lektón is its semantic correlate (= semainomenon). In Arabic grammar lafz and mainā are used in exactly the same way, viz. as terms for the two aspects of the linguistic sign. For 'sound' as a linguistically irrelevant entity, the Arabs used șaut; in Greek grammar we find in this case also phöne. Lafż and ma'nā remained the

${ }^{40} \mathrm{Cf}$ above, chapter VIII, note 67.

41 Amm comment in Aristot de interpret 30, 18-21, ed Busse [G75], cf. sh 35 , $1-2,10-1,38,3-4,39,4-5$.

42 Apoll Dysk synt. 113,11

${ }^{43} \mathrm{Cr}$ above, chapter VIII

44 Or diloumenon, cf Schneider's Index, s $v$, only once, the term lektoin is used in combination with phône, adv. 136, 32 Heinrıchs, 1969, 69-82, discusses the significance of the $m a^{\prime \prime} n \bar{a} / / a / z$ controversy in literary theory 
current expressions, both in Bașrian and Kūfan grammar, ${ }^{45}$ and the distinction was maintained by later grammarians.

There is no direct proof, apart from the resemblance in meaning (the verb anā could translate the Greek verb légein, to intend), that mánā was a calque of the Stoic lektón, but whatever may have been the terminological connection between the Greek and the Arabic pair of words, it seems that in any case there is a link between the word maina and the Stoic term prâgma, which is used as a synonym of lektón. At first, prâgma had the non-technical meaning of '(some)thing'. ${ }^{46}$ Then, in Stoic terminology, it received the meaning 'thing signified by the sounds, meaning' (= lektón). Still later, we find prâgma mostly in the sense of 'something abstract', as against sôma, which denotes a concrete object. This new meaning may have been prompted by the fact that the Stoa believed the prágmata (in the Stoic sense of 'meanings') to be bodiless. ${ }^{47}$ In its new meaning, the word is used for instance by Dionysios Thrax, who divides words of the nominal class into concrete and abstract ones: 'Noun is a part of speech with cases, which can signify a body or an (abstract) thing' ${ }^{48}$ We find the same division into abstract and concrete nouns with Zamahšarī, who uses the terms ism ain (concrete noun) and ism mainan (abstract noun) for the two categories of nouns. ${ }^{49}$ Here the word maina, which is supposed to be the translation of the Stoic term lektón, appears as a translation of the word prâgma, which-as we have seen-was used in Stoic terminology as a synonym for that same term lektón with the sense of 'meaning'. Ibn Ginni uses the same terms 'ain and ma'nā, and he even gives as the first two examples for the category of the concrete nouns the very two nouns used by Dionysios Thrax in this context: '.. the masdars are the generic expressions for the abstract nouns (ağnās al-ma'äni), just as other words are the generic expressions for the concrete nouns (ağnäs al-äyän), for instance "man", "horse", "boy", "house", "garden"...'so

As a consequence of the abstract meaning of the word maina and of the confusion in the Greek world about the precise meaning of the word lektón, which was often thought to be equivalent with the

\footnotetext{
49 For Kūfan grammar, ef e g Ta'lab, Mağ 2, 387, 3 sqq

46 $\mathrm{Cr}$ e g Aristot de interpret 17 a 38

$47 \mathrm{Cf}$ above, note 38

4 Dion Thr 24, 3 [G 76]

$49 \mathrm{Zam}$ Muโ 5,3

so b Gin $\underline{H}$ as $2,206,8-10$ [A $\mid I S$ ]
} 
notions 'idea, thought', we find $m a^{\text {in }} \bar{a}$ in the translations of Greek philosophical writings as a synonym for the Aristotelian nóèma. We do not agree with van Ess that this translation was caused by the nearly identical meaning of the two terms: ${ }^{51}$ the difference between thought and meaning was fundamental in Stoic logic, as we have explained above. But this difference was misunderstood or not understood at all in classical antiquity. ${ }^{52}$ This misunderstanding of the meaning of lektón and prâgma also explains the translation of the Greek term logos (sentence) by maina in the text of Hunain. ${ }^{53}$ Possibly there was also some ambiguity, caused by the use of prâgma in some contexts where it almost seems to mean 'sentence'. ${ }^{54}$ The confusion reaches its height in the commentary of al-Fārābì, who translates the Aristotelian word prágmata by ma'āni, apparently because he misunderstood the word and took it in its Stoic sense. Aristotle, of course, did not know this Stoic sense: he used the word for the objects in the outer world (which are indicated in Stoic terminology by the word tunchánonta). ${ }^{55}$ The same incorrect translation is found in Gābir ibn Hayyān. ${ }^{56}$

In view of the aforegoing we must distinguish between two uses of the word mainā: on the one hand, we have maina as the counterpart of laf, , in the sense of 'meaning correlating with a sound'; on the other hand, we have maina in the sense of 'something abstract'. Possibly under the influence of the second use, maina is often used in almost the same way as the eidos of Platonism: it is then an abstract correlate of something physical in the physical world. This abstract correlate can be situated within or outside the mind, i.e. in the speaking subject or in the objects. The 'meaning which resides within the mind' (maina $q \bar{a}$ 'im $f \hat{i}$ ' $n$-nafs) has been the hotly debated subject of many discussions. Relevant information can be found in the chapter dealing with the refutation of those who claim that speech is a meaning within the mind, in the seventh book of 'Abd al-Gabbār's Mugni. ${ }^{57}$ When his adversary tries to convince him that this supposed meaning within the mind is identical with thought, Abd al-Gabbār retorts: 'and if he says "what I mean is thought and reason, because

\footnotetext{
¿1 van Es. 1970. 33, n 62

92 Eg Simpl comment in Aristol caleg 10,3 44,, who sdys that lek $i \dot{a}$ are thoughts

53 Galje, 1965, 280

54 Diog Ldert 7,64. id 7,66= SVF 2. 186

55 Far Sarh, 27, 23 = Aristol de interpret 16 d 7 . also Aristot top 108 a 18 sqq. soph el 165 a 6-14, on prágmata = Iunchánomia Long, 1971, 80

so Gàbır, ap Kraus. 1942, 2, 258. nn 4-5
} 
they are speech (kaläm), and what we hear is an indication of it", we answer: "if that is what you mean, you use the wrong terms, although you hit on the right meaning - just as someone who claims that movement is a meaning within the mind, thereby indicating the will (i.e. it was never our purpose to deny the existence of thought: the only thing you have done is to give it another name). We know for sure that there is no connection between thought and the expression (ibära) of that thought. So, how could the expression be called an indication (daläla) of that thought?"'. ${ }^{58}$ Here we find expressed in a somewhat crude way the essence of the Stoic theory that there is no identity of thought and speech. Otherwise, as "Abd al-Gabbār puts it, it would be impossible to say that someone "speaks without thinking". We will find Ibn Hazm using the same theory.

On the other hand, we cannot identify the $m a^{*} a \bar{n} i$ with the physical objects themselves, in the way al-Fārābi and Gābir did in the passages quoted above-probably because they misunderstood the meaning of the Aristotelian term prágmata. When Fārābì talks about the 'traces (ătarr) in the mind, which are imitations of meanings existing outside the mind', ${ }^{59}$ he is in all probability referring to physical objects. On the other hand, when the Mutazilites are talking about the ma'äni outside the mind, they are referring to something non-physical within the objects.

The meaning of the term mainā in the works of the Mu'tazilite philosopher Mu'ammar (d. 835/220) has been studied by Frank. ${ }^{60}$ The gist of his conclusion is that ma'na often receives the meaning 'cause' ('illa). ${ }^{61}$ This means that maina is 'the intrinsic causal determinant of the thing being so', in other words: the inhering of a certain accident in a certain substance is caused by an infinite series of causal determinants (maiani)-these determinants are infinite because each of them has to be caused by another one. This is the 'coercive cause' (ma na

57 'Abd al-Gabbār. Mugni, 7, 14-20

sy Ib. 18, 6-11 [A 116] Probably, 'Abd al-Gabbār's adversary in thıs discussion was

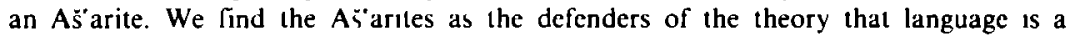
$m a \cdot n \bar{a} q \bar{a}^{\prime}, m$ fí 'n-nafs in a treatise of the Hanbahte Ibn Aqil (d \pm 1095/490), Rasāill, pp 22 sqq

${ }^{59}$ Far Sarh, 24, 24 - 25, I [A 117]

o) Frank, 1967, ef Nader, 1956, 208-10

61 To Frank's quotations we may add b Hazm, Ihk 8, 1129. 9-10. 'Some of them call the causes ('ilal) meanings ( $m a^{\prime} a \bar{a} i \bar{i}$ ), and this is one of their grossest heresies, and a false doctrine of their followers, because meanings are the explanation of sounds (sc and not the causc of somethıng)' [A 1 18] 
$m \bar{u} g$ ib), of which 'Abd al-Gabbār speaks. ${ }^{62}$ When there is in everything something which causes it to be the way it is, and when this something is called maina (meaning), we may naturally suppose that this 'meaning' is necessarily connected with the word which indicates the object - which is what one Mu'tazilite actually holds. ${ }^{63}$ We will not enter here into the question which of the two theories originated first, and whether we can explain Mu'ammar's theories from this opinion about meaning, or the other way round.

It is not necessary, though, to go as far as the Mu'tazila, and conceive of the mana as a sort of autonomous cause within the object, always coexisting with the object itselr. We may also regard them as intentiones universales in the objects, put there by Allāh, and forming the material for the thinking mind. This conception is found in the psychological theories of Ibn Rušd and Ibn Siñā. ${ }^{64}$ In their theories, ma'āni are those elements in the objects which are not perceived by the physical senses, but only by some sort of perceiving faculty of the mind (called by Ibn Rušd quw'wa mutafakkira and by Ibn Sina quwwa bätina ): ${ }^{65}$ "As for the meaning, it is that which is perceived by the mind within the object that is perceived, without the senses being able to perceive it (sc. that meaning) in the first place'. ${ }^{66}$ With this we may compare the Stoic definition of 'meaning' we quoted above-'(sèmainómenon) is the meaning (prâgma) itself, which is indicated by it (sc. the sound), and which we grasp in its correlation with our understanding'- $:^{67}$ in the Stoic definition thought and meaning are parallel developments in the mind, whereas in the theories of Ibn Rušd and Ibn Sinna meaning is situated within the physical objects. In that case, the meaning of ma'ani is very close to the Aristotelian concept of 'form'. There is a faint reminiscence of Ammonios' incorrect observation that the lektón is something between the concept and the object-and not something between the sound and the concept, as he ought to have said. ${ }^{68}$

All this is absolutely unacceptable to Ibn Hazm (d. 1064/456). For him as a Zāhirite and a profound believer in the creation of speech by

\footnotetext{
${ }^{62}$ E g. 'Abd al-Gabbār, Mugnī, 7, 15; 7, 19, 8.

${ }^{63}$ Cf chapter IX, note 65

64 Cr Gatje, $1971^{b}$.

65 Cr. Gaitje, 1965.

66 b. Sin Sıfä', 43 [A 119], cf. Gätje, 1965, 279.

${ }^{67}$ SVF 2, 166; cf. also the remarks in the scholia D T on abstractions, 217, 7-8, $360,8-11 ; 572,17$.
}

${ }^{60} \mathrm{Cf}$. above, note 26 . 
Allāh, the meaning of a word is not identical with something in the objects, nor with something in the mind: meaning is something objective connected with the phonetic expression. A word has a meaning, because Allāh provided it with that meaning. We dare not interpret that meaning otherwise than literally, not to mention changing it. We must accept the apparent and evident meaning of speech, such as it is evidently understood by everyone in common discourse (zähir). ${ }^{69}$ This means that the relation between a word and its meaning is necessary, not because of an infinite series of ma'ani as in the theories of Mu'ammar, but because Allāh created words and meanings together. Our own intention (maqșüd) can only be expressed in accordance with the objective intention of the word (i.e. the meaning): 'It is correct to say that what is intended (muräd) by the imperative is a meaning (maina) reserved to its phonetic expression and to its morphological structure'. ${ }^{70}$ (i.e. the imperative has a meaning, and our role is restricted to putting that meaning to a use). The meaning correlates with an object in the physical world (musammā), not with our concept of that object. As the result of completely different reasons and motives, Ibn Hazm and the Stoa arrive at the same point of view: meaning and concept are different entities, although they are both correlated with the physical objects.

Finally, we must point to another meaning of the term maina, namely 'intention', almost synonymous with terms such as mu'annā and maqșü. Probably this sense was in part brought about by the meaning of the verb from which maina is derived: 'ana 'to intend'. ${ }^{71}$

69 Whence the name of the school, the 'Zāhirıyya', Goldzıher, 1884

${ }^{70} \mathrm{~b}$ Hazm, Ihk 3, 261, 9 [A 120]; on this passage, Arnaldez, 1956, 52, n. 2, 58 Arnaldez translates: 'Il est constant que pour l'ımpératıf, son propos (murād) est une sıgnification (ma'nā) partıcularisée par son expressıon verbale (lafz) et son intention (niyya), apparently reading bi-niyya instead of binya We cannot agree with this translation, because ibn Hazm speaks nowhere before in this chapter about the niyya, and because the combination lafz wa-hinya (or lafz wa-binā') is a standard expression. What is more, we do not believe that Arnaldez' interpretation of my'ya as intention significative' is correct The lerm niyya is generally used with the sense of 'intention of the speaker' (Sib. Kıt 1, 123, 11; 1, 125, 13, 1, 126, 4; b Gin Has 1, 309, 9, 1, 313, 14 , b. Ka1s. ap Zağg. Mağ. 320, 6, b Anb. Ins 36, 11; 198, 5; 259, 17; 287, 21), and never with the sense of 'objective grammatical meaning without corrclation with the intention of the speaker' (Only once have we found nıyyat al-ıdä/a, b Ğin Has 2, 303, 10.) Another signification Zağğ Iḍ. 103, 3: with the force of a vowel (fi niyya haraka)

71 Rāzi, Maf. 1, 24, 16: '... because the meanıng is an interpretation of the thıng, hınted at by someone and intended by hın' [A 121] Cf. mu annā (Zağğ Lām 23, 10) and maniyya (b Gin. Has. 2, 300, 1); maqșüd is used in this sense b Anb Ins 48, 5; 54,$20 ; 63,20 ; 139,1, \mathrm{Zağg}$ Iḍ 134, 2 The first two of these synonyms are probably derıvatives of maina 
After the completion of my manuscript I received a copy of the dissertation of dr. J.R.T.M. Peters, entitled God's created speech. A study in the speculative thought of the Mu'tazili Qâdi l-Qudāt Abū l-Hasan 'Abd al-Ğabhär bn Ahmad al-Hamadäni (diss. Nijmegen; Leiden, 1976). Peters analyses here for the first time in great detail the structure and terminology of 'Abd al-Ğabbār's thought, especially in the seventh book of the Mugni. I will restrict myself to the enumeration of those passages that are of immediate interest for the subject of my study, without making any comments. The classification of sounds (Mugini, 7, 6, 16-7, 2; c؟. below, pp. 32-3): Peters, 1976, 38-42; 295-9; (Peters proposes the same emendation muqayyad that I suggested, but he translates "fluent", "bound together"; cf. ib. 139, note $160 ; 296$, note 17); ma'nä qä'im fi 'n-nafs (Mugini, 7, 14-20; cf. below, pp. 187-8) : Peters, 1976, 308-12; al-kaläm fil al-mutakallım (Mugnī, 7, 48 sqq.; cf. below, p. 152) : Peters, 1976, 209-10. Peters' analysis of 'Abd al-Ğabbār's Muğni is certainly of great importance for the study of the Arabic ideas concerning the nature of speech.

Finally I wish to refer to another book, which I regret not having been able to use, namely Troupeau's index on Sibawaihi (G. Troupeau, Lexique-index du Kitäb de Sihawayhi. Paris, 1976. Études Arabes et Islamiques, Série 3, Études et Documents, VII), which will prove to be a most useful instrument for the study of Arabic grammar. 
Diagram of the most Important Arabic Grammarians

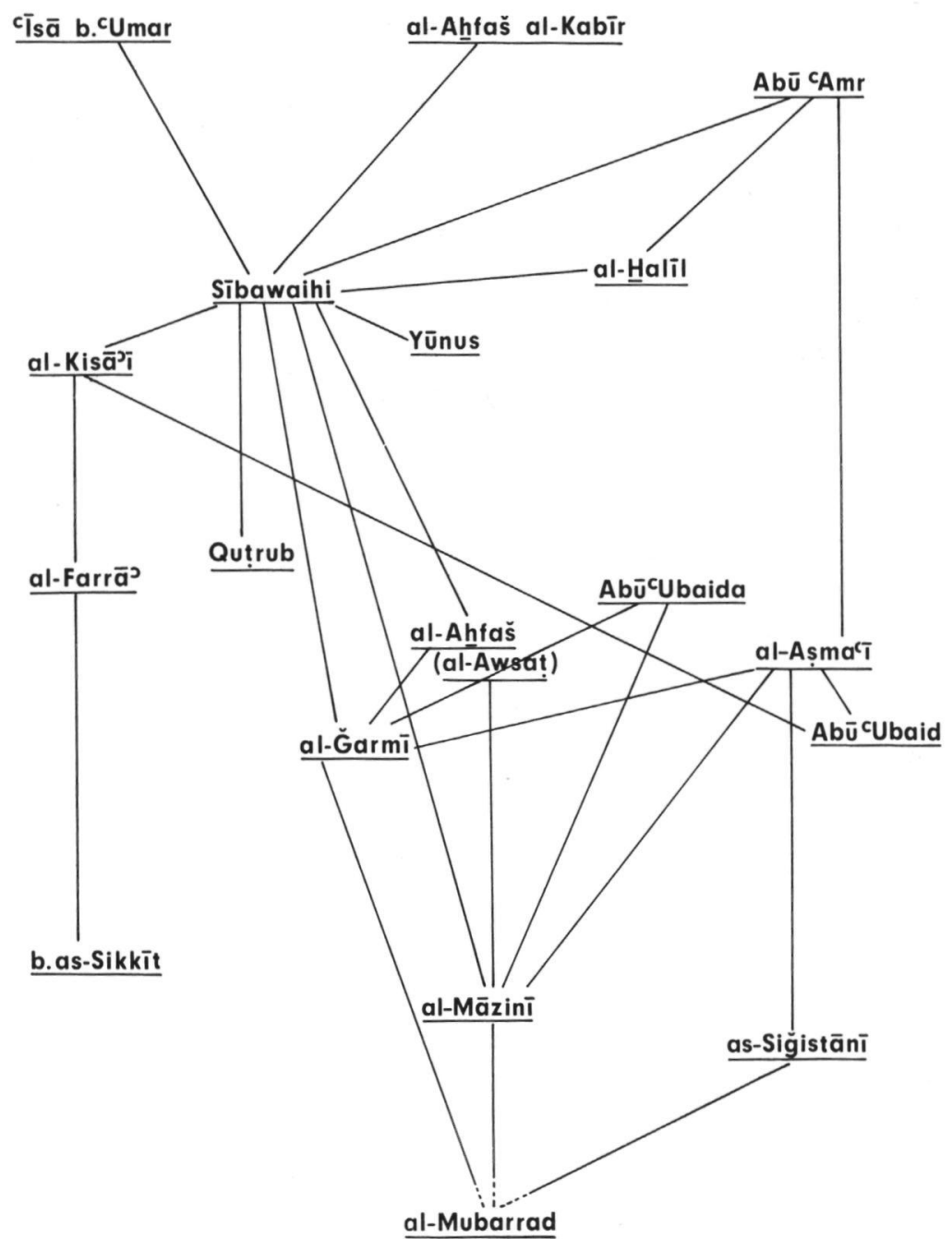


Abū 'Amr (d. 154/770)

F 32 / D 27 / G 1, 97 / N 16 / B 2, 231 / A 28/Z11/W 3, 466 Abū 'Ubaid (d. 223/837)

F 85 / G I, 105; S I, 166 / N 86 / B 2, 253 / Z 39

Abū 'Ubaida (d. 210/825)

F 68 / G I, 102; S I, 162 / N 64 / B 2, 294 / A 67 / Z 35 / W 5, 235 al-Ahfaš al-Awsaṭ (d. $215 / 830$ or $221 / 835$ )

F 61 / D 94 / G I, 104 / N 84 / B 1, 590/A 50 / Z 16/W 2, 380 al-Ah_faš al-Kabir (d. ?)

F 61 / G S I, 165/N 27/B 2, 74/A 40;48/Z 12 al-Așma'ĩ (d. 216/831)

F 72 / G S I, 163 / N 69 / B 2, 112 / A 58 / Z 35 / W 3, 170 al-Farrā' (d. 207/822)

F 129 / D 192 / G I, 118; S I, 178 / N 59 / B 2, 333 / A 34; 51 / Z 29 al-Garmī (d. 225/839)

F 81/D 111/G I, 108 / N 90 / B 2, 7 / A $72 / Z 16 /$ W 2, 485 al-Halīl (d. 175/791)

F 37 / D 30 / G I, 98; S I, 159/N 27/B 1, 557/A 38/Z 13 / W 2, 244

Ibn as-Sikkit (d. 244/858)

F 158 / G I, 120; S I, 180 / N 109 / B 2, 349 / Z 40

'Isā ibn 'Umar (d. 149/766)

$$
\text { F } 29 \text { / D 25/G I, 96 / N 14/B 2, 237/A } 31 \text { / Z } 36
$$

al-Kisā'ì (d. 183/799)

F 121 / D 172 / G I, 117; S I, 177 / N 39 / B 2, 162/A 34; 40; 51/

Z 28 / W 3, 295

al-Māzinì (d. 249/863)

F 83 / D 115 / G S I, 168 / N $111 /$ B 1, 463 / A $74 /$ Z 18/ W 1,283

Quțrub (d. 206/821)

F 65/D 108 / G S I, 161 / N 56 / B 1, 242/A 49/Z 23 /W 4, 312 Sibawaihi (d. 177/793)

F 42/D 57 / G I, 99; S I, 160 / N 35 / B 2, 229/A 48 / Z 15/ W 3, 463

as-Siğistānī, Abū Ḥāṭim (d. 182/798)

F 87 / G I, 107 / N 116 / B 1, 606 / A 93 / Z 21

Yūnus (d. 182/798)

F 34 / D 28 / G I, 97; S I, 158 / N 14 / B 2, 237 / A 31 / Z 36

$\mathbf{N}=$ b. Anb. Nuzha; $\mathbf{B}=$ Suy Bugya, $\mathbf{A}=$ Sir. Ahb.; $\mathbf{Z}=$ Zub. Tab., $\mathbf{W}=\mathbf{b}$ Hall. Waf., $\mathrm{G}=$ Brockelmann, GAL; F = Flügel, 1862; D = Daif, 1968. 


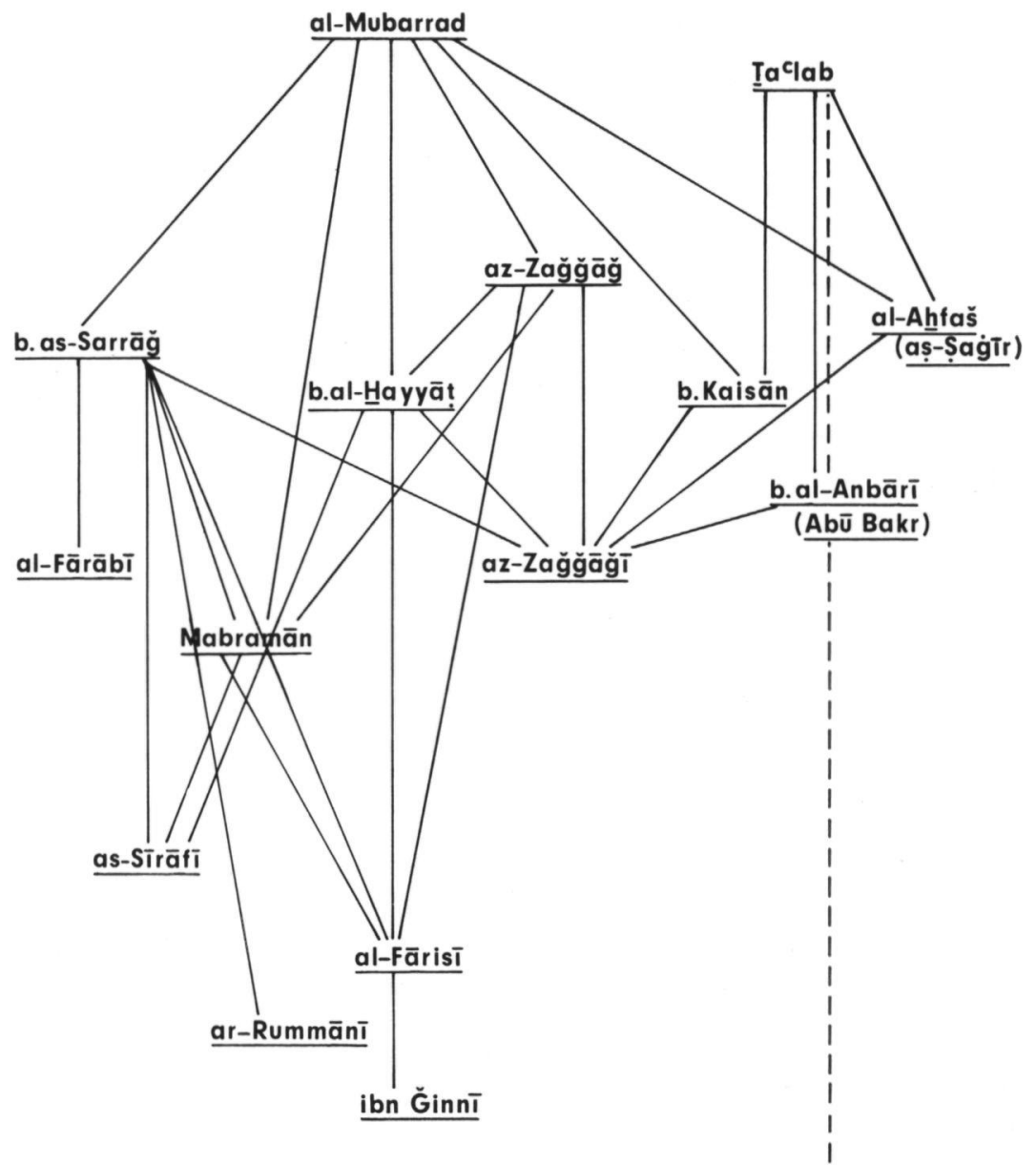

ibn Fāris 
al-Aḥfaš aṣ-Ṣagìir (d. 315/927)

F 63 / G I, 130 / N 149 / B 2, 167 / Z 25 / W 3, 301

al-Fārābì (d. 339/950)

G I, 232; S I, 375 / W 5, 153

al-Fārisì (d. 377/987)

F 110 / D 255 / G I, 116; S I, 175 / N 187 / B 1, 496 / W 2, 80 Ibn al-Anbārī, Abū Bakr (d. 328/939)

F 168 / D 238 / G I, 122; S I, 182 / N 158 / B 1, 312/Z 32 / W 4, 341

Ibn Fāris (d. 395/1004)

F 246 / D 241 / G I, 135; S I, 197/ N 190 / B 1, 352

Ibn Ginnī (d. 392/1002)

F 248 / D 265 / G I, 131; S I, 19I / N 197 / B 2, 132 / W 3, 246

Ibn al-Hayyāṭ (d. 320/932)

F 203 / D 246 / N 149 / B 1, 48 / A 109 / Z 26

Ibn Kaisān (d. 320/932 or 299/911)

F 97; 209, n. 2 / D 248 / G I, 111; S I, 170 / N 143/B 1, 18 / A $108 / \mathrm{Z} 27$

Ibn as-Sarrāğ (d. 316/928)

F 103 / D 140 / G I, 114 / N 150 / B 1, 109 / A 108/Z 52 / W 4, 339

Mabramān (d. 345/956)

F 96 / N 133; 151/B 1, 175/A 108 / Z 25

al-Mubarrad (d. 285/898)

F 92 / D 123 / G I, 109; S I, 168 / N 132 / B 1, 269/Z 23 / W 4, 313

ar-Rummānì (d. 384/994)

F 108/G I, 115; S I, 174/N 189 / B 2, 180/Z 27?/W 3, 299 as-Sìrāfî (d. 368/979)

F 107 / D 145 / G I, 115; S I, 174 / N 183 / B 1, 507/A 109/Z 26 / W 2, 78

Ta'lab (d. 291/904)

F 164 / D 224/G I, 121; S I, 181/N 139 / B 1, 396 / Z 31 / W 1, 102

Zağğăğ (d. 311/923)

F 98 / D 135 / G I, 111; S I, 170/N 147/B 1, 411/A 108/Z 24/

W 1,49

az-Zağğăğì (d. 337/949 or 340/951)

F 99/D 252/G I, 112/N 183/B 2, 37/Z 26/W 3, 136

$\mathbf{N}=\mathbf{b}$ Anb Nuzba. $\mathbf{B}=$ Suy Bugya, $\mathbf{A}=\operatorname{Sır} A \underline{h b}, \mathbf{Z}=$ Zub Tab. $\mathbf{W}=\mathbf{b} \underline{\mathbf{H}} \mathbf{a l l}$ War , $G=$ Brockelmann, GAL. $F=$ Flugel, 1862. $D=$ Dalf, 1968 


\section{LIST OF ABBREVIATED TITLES}

Aarsleff, H (1970), The history of lingutstics and professor Chomsky Language, 46, 1970, 570-85

Aarsleff, $\mathrm{H}$ (1974). The tradition of Condillac the problem of the origin of language in the eighteenth century and the debate in the Berlin Academy beforc Herder Hymes, 1974. 93-156

Ackrill, J (1963), Aristotle's Categories and De Interpretatıone Oxford, 1963

Allard, M (1965), Le problème des attributs divins dans la doctrine d'al-As̆"ari et de ses premers grands disciples Beyrouth, 1965

Alston, R C (1967), English Imguistlcs 1500-1800 Menston, 1967

Amer, A (1963), Luma' al-'adıllah fí 'usūl an-nahu d'al-'Anhärì Edıtıon critıque Stockholm, 1963

Amıne, O (1959), Le Stoicısme et la pensee islamıque Revue Thomıste, 59, 1959, 79-97

Anawatı, G C (1974), Etudes de philosophre musulmane Parıs, 1974 (= Etudes Musulmanes, XV)

Ansarı, Z I (1972), Islamic jurıstic terminologı before Säfïi Arabicd, 19, 1972, 255-300

Arndldez, R (1956), Grammatre et theologie chez Ith Hazm de Cordoue Paris, 1956 (= Eludes Musulmanes, III)

Asın Paldcios, M (1939), El origen del lenguaje I problemas conexos en Algazel, Ibn Sida, e Ibn Hazm Al-Andalus, 4, 1939, 253-81

Bdcher. W (1895), Anfange der hebraıschen Grammank ZDMG, 49, 1895, 1-62, 335-92

Bacher, W $\left(1970^{2}\right)$, Vier Abhandlungen uher Ahulualid ibn Ganāh Amsterdam, $1970^{2}$ (1884-9)

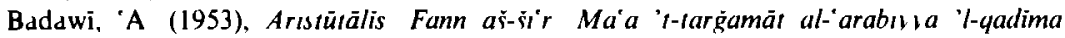
u a-šurūh al-Färäbi na-ıhn Sinā na-ıbn Rušd Qähıra, 1953

Badawi, A (1968), La transmission de la philosophie grecque au monde arabe Paris, 1968 ( = Eludes de Philosophie Médievale, LVI)

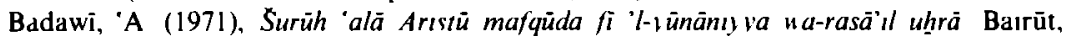
1971

Balazs. J (1965), The forerunners of structural prosodic analysis and phonemics Actd Linguisticd Academıae Scientiarum Hungarıcae, 15, 1965, 229-86

Barwıck, K (1922), Remmiıs Palaemon und die romische Ars Grammatica Leipzig, 1922 (Hildesheim, 19672)

Barwick, K (1957), Probleme der stotschen Sprachlehre und Rhetorik Berlın, 1957

Bauer, G (1972), Athanasius von Qus Quladat at-1ahrir fi $\mathrm{\prime lm}$ at-tafsir Eine koptısche Grammank in arabischer Sprache aus dem 13/14 Jahrhundert Freiburg, 1972

Baumstark, A (1900), Arisioteles bei den Sirern vom V-VIII Jahrhundert Leıpzig, 1900

Baumstark, A (1968²), Geschichte der syrischen Literatur Bonn, $1968^{2}$ (1922)

Baumstark, A /Rucker, A (1964), Die aramalsche und sirische Literatur B Spuler (ed), Handbuch der Orientalıstık, I, 3, Leiden/Koln, 1964, 162-204

Bell, H I (1946), Egypt from Alevander the Great to the Arab conquest A studi in the dif/usion and decay of Hellenism Oxford, 1946 (1966)

Bell, R (1926), The origin of Islam in its Christian environment London, 1926 (1968)

Benedıkısson, Hr (1972), The First Grammatıcal Treaııse Reykjavık, 1972 (= Háskolı Islands, Publications in Linguistics, I)

Bergè, M (1972), Mérites respectıves des natıons selon le Kı̈äh al-ımtä* na-'l-mu'änasa d'Abū Hayyān al-Tauhidi Arabıca, 19, 1972, 165-76

van den Bergh, S (1954), Averroes' Tahafut al-tahafut Translated from the Arablc with introduction and notes London, 1954 
Bergsträsser, G. (1913), Hunain thn Ishäq und seme Schule Leıden, 1913.

Bernand, M. (1972/73), La notion de 'ilm chez les premiers Mutazilites Studia Islamica, $36,1972,23-45 ; 37,1973,27-56$.

Blau, J (1963), The role of the Bedouns as arbiters in lingutsuc questions and the masiala zunbüriyya. Journal of Semitic Studies, 8, 1963, 42-51.

Bocheński, I M (1956), Formale Logık Freiburg, 1956.

Bonebakker, S. A. (1966). Some early definttons of the tawriya and Safadi's Fadd al-xitam "an at-taurtya u'a-l-Istıxdäm. The Hague/Paris, 1966.

Bouman, J (1959), Le conflit autour du Coran et la solutıon d'al-Bāqılläni. Amsterdam, 1959

Bräunlich, E (1926), Al-Halil und das Kıtäh al-Ain Islamica, 2, 1926, 58-95

Bravmann, M. (1934), Materialien und Untersuchungen zu den phonetischen Lehren der Araher. Gottungen, 1934.

Brockelmann, C , (GAL) Geschichte der arahischen Literatur, 2 den Supplementbänden angepasste Auflage 2 vols. Leiden, 1943-49 Supplementhände, 3 vols. Leiden. 1937. 42.

Brockelmann, C. $\left(1974^{2}\right)$, History of the Islamic peoples New York, $1974^{2}$ (translated from the German orıgınal, Geschichte der islamischen Völker und Staaten, Munchen, 1943)

Brough, J. (1951), Theories of general lingurstıs in the Sanskrit grammarians Transactions of the Philological Society, 1951, 27-46.

Browning, R (1969), Medieval and Modern Greek London, 1969

Brunschvig, R. (1970), Los teólogos-juristas del Islam en pro o en contra de la lógica griega ıbn Hazm, al-Gazäli, ıbn Taymırya Al-Andalus, 35, 1970, 143-77

Brunschvig, R. (1971), Valeur et fondement du ratsonnement jurtdique par analogie d'après al-Gazäli. Studıa Islamıca, 34, 1971, 57-88

Brunschvig, R (1972), Rationalié et Iradition dans l'analogle furidico-religletuse chez le Muitazllite 'Ahd al-G̈abhär. Arabica, 19, 1972, $213-21$

Bujnoch, J (1972), Zuischen Rom und By:anz. Graz, 1972² (= Slavische Geschichtsschreiber, I).

Cabanelas, D. (1956), Un opuisculo médito de Algazel El 'Libro de las mintiones intelectuale's' Al-Andalus, 21, 1956, 19-58.

Canard. M (1973), Byzance et les Musulmans du Proche Orient London, 1973.

Cantıneau, J. (1960), Etudes de lingussıque arabe Parıs, 1960

Caron, W. J.H. (1947), Klank en teken bil Erasmus en onze oudste grammatict. Groningen/ Batavia, 1947 (reprinted in W.J. H Caron, Klank en teken. Verzamelde taalhumdige studies, Groningen, 1972, 1-128)

Carter, M G (1972), Les origines de la grammare arabe Revue des Etudes Islamiques. $40,1972,69-97$

Carter, M G (1973), An Arab grammarian of the stath century A D JAOS. 93, 1973. 146-57

Carter, M G $\left(1973^{\mathrm{b}}\right)$, Sarf et huläf Contribunon à l'histomre de la grammatre arabe Arabica, 20, 1973, 292-304

Chomsky. N. (1966). Cartesian linguistics. A chapter in the histort of rattonalist thought New York/London, 1966

Christensen, J (1962), An essay on the umul of Stou philosophy. Kobenhavn, 1962

Cohen. D. (1970), Les formes du prédicat ell arabe et la théorte de la phrase chez les anciens grammarrıens Mélanges Marcel Cohen. The Hague/Parıs, 1970, 224-8

Conen, P.F (1964), Dıe Z'uttheorıe des Arıstoteles München. 1964

Corcoran, J. (ed ) (1974), Ancient logic and its modern interpretalions Dordrecht/Boston. 1974 ( = Synthese Historical Library, 9)

Coseriu, E (1970), Dic Geschichte der Sprachphilosophe von der Antike bis zur Gegenuart Teil I Von der Antike hu Leihm= Tubingen, 1970 
Daıber, H. (1968), Die arabısche Übersetzung der Placıta Phılosophorum. Saarbrücken, 1968.

Daif, S. (1968), Al-Madōrıs an-Nahwwyya. Mișr, 1968.

Daniélou, J. (1956), Eunome l'Arıen ê l'exégèse néo-platonicienne du Cratyle. Revue des Etudes Grecques, 69, 1956, 412-32.

Deıchgräber, K. (1930), Die grıechische Empirıkerschule Berlın, 1930 (Berlın/Zürich, 1965)

Derbolav, J. (1972), Platons Sprachphilosophie im Kratylos und in den späteren Schriften. Darmstadt, 1972

Diels, H (1899), Elementum Eine Vorarbeut zum griechischen und lateinischen Thesaurus. Leıpzig, 1899

Diem, W (1970/71), Nomen, Substantiv und Adjektıv bet den arabischen Grammatikern. Orıens, 23-4, 1970-71, 312-32.

Dınékov, P. (1972), La personaltté de Consıanın-Cyrılle le philosophe. Monographies. L'ceuvre de Constantın-Cyrille le phılosophe. Solia, (1972)

Donnet, D (1967), Le tratté Peri suntáxeôs lógou de Grégoire de Corinthe. Bruxelles/ Roma, 1967.

Donnet, D. (1967 $)$, La place de la syntaxe dans les traités de la grammatre grecque. L'Antiquité Classıque, 36, 1967, 22-48

Downey, G (1966²), A history of Antioch. Princeton, 1966².

Dunlop, D M (1951). The evistence and definition of philosophy From an Arabic tevt ascribed to al-Färäbi Iraq, 13, 1951, 76-94

Dunlop, D M (1959), The translations of al-Bırriq and Yahyā Journal of the Royal Asıatic Sociely, 1959, 140-50.

Duval, R (1892), Historre d'Edesse, polttıque, religıcuse et htératre Parıs, 1892 (1975)

Duval. R $\left(1907^{3}\right)$. La litlérature sirlaque. Paris, $1907^{3}$.

Dvornik, F (1950), Photus et la réorganisatıon de l'Académic Patrarcal Mélanges Paul Peeters, Bruxelles. 1950, II, 108-25

Eche. Y (1967). Les hibliothiques arabes au Moyen Age Damas. 1967.

Edelstein, L (1933), Empirı und Skepsis in der Lehire der griechischen Empirikerschule Quellen und Studien zur Geschıchte der Naturwissenschaften und Medizin, 3, 1933 , 45-53

van Ess, J (1965), Ihn Kulläh und dic Mihna Oriens, 18-9, 1965-6, 92-142

van Ess, J (1966), Dic Erkenntnıslehre des 'Adudaddin al-Ici Wiesbaden, 1966.

van Ess, J. (1970), The logical structure of Islamic theologi. Grunebaum, 1970, 21-50

Fehling. D (1956/57-8), Varro und die grammatische Lehre von der Analogie und der Flewon Glotta. 35. 1956. 214-70, 36. 1957-8, 48-100

Festugière. A J (1959), Antıohe paienne et chrétıenne Parıs, 1959.

Fınnegan. J (1957), Al-Färäbi ê l' Peri noù d'Alevandre d'Aphrodise. Mélanges Louıs Massignon, Damas. 1957, II, 133-52

Fischer, J. B (1962-3/1963-4), The origin of triparute division of speech in Semilu grammar Jewısh Quarterly Review, (N S ), 53, 1962-3, 1-21 ; 54, 1963-4, 132-60.

Fleısch, H (1961), Traté de phlologie arahe Vol I Beyrouth, 1961.

Flügel, G. (1862), Die grammatıschen Schulen der Araher Erste Ahthe'lung Leıpzıg. 1862 (1966).

Frank, R.M (1966), The structure of created causality according to al-As̆ari Studia Islamica, 25, 1966, 13-75.

Frank, R M (1967), Al-Ma'na some reflections on the technical meanings of the term in the kaläm and its use in the physics of Mu'ammar. JAOS, 87, 1967. 248-59.

Frank. R M. (1969), The divme attributes according to the teaching of Abu l'Hulhayl al-'Allât Le Muséon, 82. 1969. 451-506.

von Fritz, K. (1949), Ancient mstruction in grammar American Journal of Philology, 70, 1949, 337-66. 
Fuchs, F. (1926), Die höheren Schulen von Konsıanımopel im Mitrelalter Berlın, 1926 (= Byzantınısches Archıv, 8)

Fück, J $\left(1955^{2}\right)$. 'Arahiyva Recherches sur l'historre de la langue et du stlle arahe. Paris, 19552 (translated from the German original, Arabiva Untersuchungen sur arabischen Sprach- und Stılgeschichte, Berlin, 1950)

Furlanı, G (1937), Sur le Stoicısme de Bardesane d'Edesse Archív Orıntálnı, 9, 1937. 347-52

Gabrielı, F (1929), Al-Ma'mūn e gl/ Alıdı Leıpzig, 1929 (= Morgenlandısche Texte und Forschungen, 1I, 1)

Gabrielı, F. (1965), A short history of the Arabs. London, 1965.

Gabrielı, F (1968), Mahomet et les grandes conquêtes Parıs. 1968

Gabučan, G M (1972), Teorija arlıklja i prohlemy arabskogo sintaksisa Moskva, 1972.

Gallavottı, C. (1954), Il syndesmos in Aristotele La parola del passato, 26, 1954, 241 sqq.

Gatje, H (1965), Die 'inneren Sinne' bet Averroes ZDMG, 115, 1965, 255-93

Gätje, H (1971), Dıe Glıederung der sprachlıchen Zeıchen nach al-Färähi Der Islam, 47, $1971,1-24$

Gätje, H $\left(1971^{\mathrm{b}}\right)$, Studien zur Überheferung der arıstotelischen Psychologıe im Islam Heidelberg, 1971

Gätje, H. (1973), Zur Syntax der Determınatıonsverhälınısse im Arabıschen Hamburg, 1973

Gätje, H. (1974), Logısch-semasıologische Theorien bel al-Gazzäli. Arabıca, 21, 1974, 151-82.

Gentinetta, P M (1961), Zur Sprachbetrachtung bei den Sophisten und in der storschhellenistischen Zell Winterthur, 1961.

Georr, Kh. (1948), Les Catégories d'Aristote dans leurs versions syro-arabes. Beyrouth, 1948.

Gesenıus, W./Kautzsch, E. $\left(1909^{28}\right)$, Hebrassche Grammatık. Leıpzıg, $1909^{28}$ (Hıldesheim, 1962).

Glück, M. (1967), Priscians Partıones und thre Stellung in der spätanuken Schule Hildesheım, 1967 ( = Spudasmata, XII).

Goıchon, A. M. (1938), Lexique de la langue philosophique d'ibn Sinä Parı, 1938

Goldschmidt, V (1953), Le système stoicten et l'idée de temps. Paris, 1953

Goldziher, I. (1884), Die Zähurıten. Ihr Lehrsystem und thre Geschichte Leıpzıg, 1884

Goldziher, 1 (1887), Das Princıp des istıshäb in der muhammedanischen Gesetzwissenschaft. Wiener Zeitschrift zur Kunde des Morgenlandes, 1, 1887, 228-36.

Gordon, E V (1957²), An introduction to Old Norse. Oxford, 1957².

von Grunebaum, G. E (ed ) (1970), Logic in classıcal Islamic culture Wiesbaden, 1970.

Gyeke, Kw. (1971), The term 'prima intentio' and 'secunda intentıo' in Arabic logic Speculum, 46, 1971, 32-8.

Haddad, F (1972), Alfäräbi's views on logic and tts relatıon to grammar. Islamıc Quarterly, 13, 1969, 192-207.

Hadịî, H. (1966), Abū Hayyān an-nahwi Bagdād, 1966.

Ḧadị̂i, H. (1967), Kitäb Sïbawaihi wa-šurūhuhu. Baġdād, 1967.

Hayes, E.R. (1930), L'Ecole d'Edesse. Paris, 1930.

Hegazi, M. M. F. (1971), Abū Sa id as-Siräfi der Sibawaih-kommentator als Grammatıker. München, 1971 (diss., 1965).

Heinrichs, W. (1969), Arabische Dichiung und griechische Poetik. Beyrouth, 1969.

Hemmerdinger, B. (1956), Les notıces et extratts des biblıothèques grecques de Baghdad par Photius. Revue des Etudes Grecques, 69, 1956, 101-3.

Hermann, T. (1926), Die Schule von Nisibis vom V. bis VII. Jahrhundert. Zeitschrift f. neutestamentliche Wissenschaft, 25, 1926, 89-122

Hiersche, R. (1955), Entstehen und Entwicklung des Terminus ptôsis, 'Fall'. Sitzungsberichte d. deutschen Akad. d. Wiss. z. Berlin, 3, 1955. 
Hittı, Ph K (1968'), Histors of the Arahs from the earlest times to the present New York, $1968^{\circ}$

Horowitz. S (1903), Uber den Einflusi des Stoucismus aul die Enturchlung der Phlosophe be den Arahern ZDMG, 57, 1903, 177-96

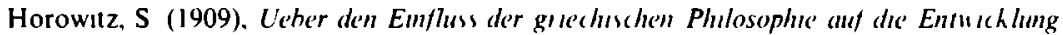
des haläm Breslau. 1909 (1971)

Houranı, G F (1971). Islamic ratonalım the ethus of :Ahd al-Gahhar Oxford. 1971

Huby. P M (1969). The transmission of Aristotle' ititings Classicd el Medidevalid. 30 , $1969,241-57$

Hymes, D (ed ) (1974), Studies in the histort of linguistics Tiaditions and paradigms Bloomington/London. 1974

'Id, M (1973), Usūl an-nahu al-arahı Qāhırd, 1973

Islamic philosophy $(1972)=$ Stern, S M /Houranı. A /Brown. V (edd). Islamic philosoph and the classical tradition Essals presented bi his friends and pupils to Richard Walzer on his seienticth hirthdal Oxford, 1972

Jadadne, F (1968), L influence du stoic isme sur la pensee musulmane Bcyrouth, 1968

Karlgren, B (1926), Philologi and ancient Chma Oslo, 1926

Khoury, A T $\left(1969^{2}\right)$, Les theologiens bizantms et I/slam Louvan, $1969^{2}$

Kıeffer, J S (1964), Galen s Institutio logica English iranslation. Miroduction and commentar) Baltımore, 1964

Kleınknecht, A (1972), Al-Qıstäs al-mustaqìm Eime Abletıung der Logıh aus dom Koran Isldmic philosophy, 1972, 159-87

Klınge, G (1939), Die Bedeutung der svrischen Theologen als Vermutter der griechischen Philosophie an dem Islam Zeitschrift I Kirchengeschichte, 58, 1939. 346-86

Kneale, W /Kneale, M (1962), The development of logic Oxford, 1962

Koerner, E F K (1976), Tonards a historiograph) of lingustics Parret, 1976, 685-718

Koller, H (1958), Die Anfange der griechischen Grammatık Glottd, 37, 1958, $5-40$

Kopf, L (1956), Religious influences on medieval arabıc philologi Studid Islamica, 5, $1956,33.59$

Kraemer, J (1959), Das Problem der islamischen Kulturgeschichte Tubıngen, 1959

Kraus, P (1942), Jäbır inn Havyān Coniributions a l'histoire des idees scientilıques dans I Islam Le Care, 1942

Kretzmann, N (1974), Aristolle on spoken sound significant by convention Corcoran. 1974, 3-21

Krumbacher, K $\left(1897^{2}\right)$, Geschichte der by zantmischen Literatur Munchen, $1897^{2}$

Kuhner, R /Bldss, F $\left(1966^{3}\right)$, Ausführliche Grammatık der griechischen Sprache Darmstadt, $1966^{3}$

Kunjunnı Raja, K (1969²), Indian theories of meaning Madras, $1969^{2}$

de Lacy, Ph H (1939), The epicurean analysis of language American Journal of Philology, 60, 1939, 85-92

de Lacy O'Leary, D D (1949), Hou Greek science passed to the Arahs London, 1949

Larkın, M T (1971), Language in the philosophy of Aristotls The Hague/Paris, 1971 (= Janua Linguarum, series minor, 87)

Liebermann, S $\left(1960^{2}\right)$, Hellenism in Jewish Palestıne New York, $1960^{2}$

Lloyd, A C (1971), Grammar and metaphysics in the Stoa Long, 1971, 58-74

Long, A A (1971), Language and thought in Stocism Long, 1971, 74-113

Long, A A (ed ) (1971), Problems in Stoucism London, 1971

Loucel, H (1963-64), L'origine du langage d'apres les grammariens arabes Ardbica, 10 , $1963,188-208,253-81,11,1964,57-72,151-87$

Madkour, I (1969'), L'Organon d'Aristote dans le monde arabe Parıs, $1969^{2}$ (= Etudes Musulmanes, $\mathrm{X}$ )

Mahd, M (1970), Language and logic in classical Islam Grunebaum, 1970, 51-83 


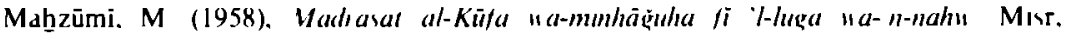
1958

Mamulıjd. L I (1965²), Grammancieshı trahıat Ahü Ali al-Färıi Semıskıje Jazykı. $1965^{2}, 2.568-84$

Marrou, H -I (1965'). Historre de l'education dans I antiqume Freibourg, 1965"

Mates. B $\left(1961^{2}\right)$, Storc logic Berkclcy/Los Angeles. 1961² (1953)

de Mauro, T (1965), Il nome del datro e la teoria de' cast giét Rendicontı delle Classe di Scienze Moralı. Storiche. e Philologiche dell'Academıd di Linceı, Roma, 20, 1965, 151-211

Merx. A (1889), Hisoria artis grammaticac apud swos Lipside. 1889 (Nendeln. 1966)

Mette. H J (1952). Parateresis Untersulhungen zu Splachtheole des Krates von Pergamon Halle, 1952

Meyerhof, M (1926). New light on Hunam thn Ishäq and his penod Bruxelles, 1926

Meyerhof, M (1930), Von Alevandrien nach Bugdad Eun Beatrag zur Geschishe' des philosophashen und medizmschen Unterrichts bet den Arabern Berlin, 1930

Meyerhor. M (1931), Johannes Grammatihos (Philoponos) ion Alevandrien und die arahische Medism Mitteılungen d deutschen Instituts $\Gamma$ dgypt Altertumskunde in Kairo, 1931, I-21

Meyerhof. M (1933), La fin de lécole d'Alevandre d'apres quelques auteurs arabes Bulletın de l'Instıtut de l'Egypte, 15, 1933, 109-23

Miel, J (1969). Pascal, Port Royal and Cartesian Lingustics Journal of the History of Ideds, 30, 1969, 261-7I

Mignucci, M (1965), Il stgnificato della logica stoica Bolognd, 1965

Misra, V N (1966). The descriptive techmique of Pänmı The Hague, 1966 (= Janud Linguarum, series practica, XVIII)

Mitteis, L/Wilcken, U (1912), Grundzuge und Chrestomathe der Papirushunde I Leipzıg/Berlın, 1912

Mohrmann, Chr $\left(1961^{2}\right.$ ), Études sur le Latın des Chretsens Romd, $1961^{2}$ (= Storid e Letteratura, 65)

Morpurgo-Taglıabue, G (1967), Lingutsuca e sulistıca di Aristotele Roma, 1967

Mosel, U (1975), Dic sintaktische Terminologie bet Sihawalh Munchen, 1975

Mubārak, M (1963), Ar-Rummāmı an-nahui fi daı šarhıhı lı-Kıäh Sıbauaıhı Dımaj̄q, 1963

Mubārak, M (1974³), An-Nahu al-'arabi, Al-'Illat an-nahuılı nä̌atuhä ua-latan-

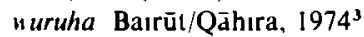

Nader, A N (1956), Le systeme philosophique des Mu'razla Beyrouth, 1956

Nağğàr, M 'A (1952), Al-Hֵasā’ıs san'a Ahi Fath 'Uțmān ıhn Gınni Qāhıra, 1952

Nau, F (1933), Les arabes chrétiens de Mésopotamie et de Sirre du VII' au VIII' uécle Paris, 1933

Nestle, E (1878), Jakob von Edessa uher den Schem hammephorasch und andere Gottesnamen ZDMG, 32, 1878, 465-508

Noldeke, Th /Schwally, F $\left(1961^{2}\right)$, Geschichte des Qorans Hıldesheım, $1961^{2}$ (Leıpzıg, 1909-29)

Ostrogorsky, O (1963'), Geschichte des byzantınıschen Stautes Munchen, $1963^{3}$ (Byzantinisches Handbuch, I, 2)

Pagliaro, A (1956), Il capitulo linguistico della Poelica di Aristotele Nuovi Saggi di Critica Semantica Firenze, 1956

Parret, H (ed ) (1976), History of linguistic thought and contemporary linguistics Berlın/ New York, 1976

Parsons, E A (1952), The Alexandrian library Amsterdam, 1952

Patton, A (1897), Ahmad ibn Hanbal and the Mihna Leiden, 1897

Peeters, P (1950), Le tréfonds ortental de l'hagıographte byzantıne Bruxelles, 1950 
Peters, FE (1968), Aristotle and the Arabs The Aristotelian tradition in Islam. New York/London. 1968

Pinborg. J (1961), Inter/ektionen und Naturlaute Classica et Mediaevalia, 22, 1961, $117-38$.

Pinborg, J (1962). Das Sprachdenke'n der Stoa und Augustıns Dialektık Classica et Mediaevalia, 23, 1962, 148-77

Pinborg. J. (1967), Die Entwicklung der Sprachtheorse im Mittelalter Minster, 1967

Pinborg. J (1972), Logık und Simantik im Mittelalıer. Stuttgart, 1972 (= Problemata, 10 ).

Pohlenz. M (1939), Die Begründung der abendlandischen Sprachlehre durch die Stoa Nachr d Gesellsch d. Wiss zu Götıngen, phıl -hist K1., NF 3, 1939

Pretzl, O (1940), Die frishslamische Altributenlehre Munchen. 1940.

Rabın, C (1951), Ancient West-Arabian London. 1951.

Radermacher, L (1951), Arinum scriplores Reste der voraristotelischen Rhetorik Wien, 1951

Reckendorf, H (1921), Arahische Sintar Heidelberg. 1921

Renou, L (1940), Le Durghalawrfl de Saranadeva Parı, 1940

Rescher, N (1964). The development of Arabic logic Puttsburgh, 1964

Rescher, N (1964) ), Studies in the history of Arahic logic Pittsburgh, 1964.

Rescher, N (1966), Studies in Arabic philosophy. Pittsburgh, 1966.

Reuschel, W. (1959), Al-Halil ibn Ahmad, der Lehrer Sibawaihs, als Grammatıker Berlın, 1959

Rist, J M (1969), Stolc philosophy Cambridge, 1969

Rosenthal, F. (1943), Ahmad ibn at-Tayylh as-Sarahsi. New Haven, 1943

Rosenthal, F. (1951), New fragments of as-Sarahsi. JAOS, 71, 1951, 135-42.

Rosenthal, F (1965), Das Fortleben der Anuke im Islam. Zürich, 1965

Rosenthal, F $\left(1968^{2}\right)$, A history of Muslim historiography. Leiden, $1968^{2}$.

de Rıj, R R G. (1968), St. Augustine on language. Studies presented to Roman Jakobson Cambridge (Mass), 1968, 91-104.

de Sacy, A I S (1829), Anthologıe grammaticale arabe. Parıs, 1829 (1973)

Sadan, A. (1973), À propos de marlaha remarques sur l'étıquette dans le monde musulman médiéval Revue des Études Islamıques, 41, 1973, 51-69

Saffrey, H -D (1954), Le chréfien Jean Philopon et la survivance de l'école d'Alexandrie Revue des Études Grecques, 67, 1954, 396-410

Sāmarrā'ì, F.S. (1971), Ad-Dırāsāt an-nahn'yya w'a-'/lugawıyya 'inda 'z-Zamahšari Bagdād, 1971.

Sambursky, S. $\left(1971^{2}\right)$, Physics of the Stoics. London, 1971 2

Scaglıone, A (1970), Ars grammatica The Hague/Parıs, 1970 (= Janua Linguarum. serıes minor, 77$)$.

Scarpat, G (1950), Il discorso e le sue partı in Artstotele. Arona/Milano, 1950.

Schaade, A. (1911), Sibawaihi's Loutlehre Leiden, 1911

Schacht, J (1950), Orıgins of Muhammadan jurisprudence Oxford, $1950\left(1967^{4}\right)$

Schacht, J $\left(1950^{\mathrm{b}}\right)$, Foreign elements in ancient Islamic law Journal of Comparative Legislation, 32, 1950, 9-17.

Schacht, J (1971), Theology and law in Islam. G. E von Grunebaum (ed.), Theology and Law in Islam. Wiesbaden, 1971, 3-23

Schall, A. (1960), Studien uber griechische Fremdwörter im Syrischen Wiesbaden, 1960.

Schemmel, F. (1909), Die Hochschule von Alexandria im 4./5. Jahrhundert. Neue Jahrbücher, 24, 1909, 438-57.

Schmidt, R (1839), Stoicorum grammatıca. Halle, 1839 (Amsterdam, 1967).

Schrijvers, P.H (1974), La pensée de Lucrèce sur l'orıgıne du langage. Mnemosyne, 27, 1974, 337-64.

Seale, M. (1964), Muslim theology. London, 1964 
Segal, J. B. (1953), The diacritical point and the accent in Syriac. London, 1953 (London Oriental Series, 2).

Segal, J. B. (1970), Edessa, the blessed city. Oxford, 1970.

Semaan, Kh. I (1968), Lingutstics in the Middle Ages. Phonetic studies in early Islam. Leiden, 1968.

Sezgin, F. (1967), Geschichte des arabischen Schrıftıums. Band I. Leiden, 1967

Shehaby, N. (1975), The influence of Storc logıc on al-Jassās's legal theory J.E Murdoch/E. D. Sylla, The cultural context of Medieval learning. Dordrecht/Boston, 1975, 61-85 (= Synthese Library, 76).

Siebenborn, E (1976), Die Lehre von der Sprachrichigkelt und thren Kriterien. Studien zur antiken normativen Grammatık. Amsterdam, 1976

Sıttıg, E. (1931), Das Alter der Anordnung unserer Kasus. Tübinger Beiträge z. Alterturnswissenschaft, 13, 1931.

Sourdel, D. (1962), La politique religieuse du calıfe 'Abbäside al-Ma'mün. Revue des Éludes Islamiques, 30, 1962, 27-48

Speck, P (1974), Dıe katserliche Unıversität von Konstantinopel. München, 1974 (= Byzantınisches Archiv, 14).

Spuler, B (1952), Geschichte der islamischen Länder Leiden, 1952 (= Handbuch der Orıentalistik, 6)

Steınschneider, M. $\left(1960^{2}\right)$, Die arabischen Übersetzungen aus dem Griechischen Graz, $1960^{2}$ (Leipzig, 1897)

Steınthal, H. $\left(1890^{2} / 1891^{2}\right)$, Geschuchte der Sprachwissenschaft het den Griechen und Römern. Berlın, $1890^{2} / 1891^{2}$

Stough, Ch L (1969), Greek skepucısm A study in epıstemology. Berkeley/Los Angeles, 1969

Stratos, A. N (1965), Byzantıum in the seventh century. I. Amsterdam, 1965. (translation of the Greek original, To Vizándion stòn z' éona, Athıne, 1969)

Tarazi, F H. (1969), Fi uṣül al-luga wa-'n-nahw'. Bairūt, 1969

Temkın, O (1973), Galenısm. Rise and decline of a medical philosophy Ithaca/London, 1973

Troupeau, G (1962), La grammare à Bagdad du IX au XIII siècle Arabica, 9, 1962, 397-405.

Troupeau, G $\left(1962^{\mathrm{b}}\right)$, La nolıon de temps chez Sibawaih. Comples Rendus du Groupe Linguistıque d’Études Chamilo-Sémitiques de Paris, 9, 1962, 44-6

'Ubardi, R.A. (1969), Abū 'Uı̣mān al-Mäzıni wa-mad̆ähbuhu fi 's-sarf na-'n-nahu. Bagdād, 1969

Vasiliev, A.A $\left(1970^{2}\right)$, History of the Byzantine empire Madison, $1970^{2}$.

Vasiliev, A. A (1935-68), Byzance et les Arabes. I-IV. Bruxelles, 1935-68

Virıeux-Reymond, A. (1941), La logique et l'épistémologie des Stoiciens Chambéry, 1941

Vöobus, A. (1962), The statutes of the school of Nisibis Stockholm, 1962.

Vryonis, S (1971), The decline of medieval Hellenism in Asia Minor and the process of Islamization from the eleventh through the fifteenth century. Berkeley, 1971

Walzer, R (1944), Galen. On medical experience. Oxford, 1944.

Walzer, R (19632), Greck into Arahic. Essays on Islamic philosophy. Oxford, $1963^{2}$

Watt, W M. (1971), The great community and the sects. G E von Grunebaum, Theology and law in Islam, Wiesbaden, 1971, 25-36.

Weıl, G (1913), Dıe grammatıschen Streilfragen der Baster und Kü/er. Leıden, 1913.

Weiss, B G (1966), Language in orthodox Muslim thought a study of 'wad' al-lughah' and its development. Princeton, 1966 (diss microfilm).

Weiss, B G (1974), Mediaeval Muslmm discussions of the origin of language. ZDMG, 124, 1974, 33-41

WeıB, J. (1910), Die arabische Natıonalgrammatık und die Lateiner ZDMG, 64, 1910, 349-90. 
Wild, S. (1965), Das Kıtäh al-'ain und die arahische Lexıkographie Wiesbaden, 1965.

Wright, W. (1964 3 ). A grammar of the Arabic language Cambridge, $1964^{3}$.

Wüstenfeld, W. (1841), Geschichte der arabischen Ärzte und Naturforscher. Gottıngen, 1841.

Zeitlın, S (1964), Hillel and the hermeneutic rules. Jewish Quarterly Review, 54, 1964, $161-73$

Zırın, R. (1974), Inarticulate noises. Corcoran, 1974, 23-5

Zlinszky, J. (1960), Zur Frage der Verschollenhett im römischen Recht Acta Antıqua Academiae Scientıarum Hungaricae, 8, 1960, 95-132. 


\section{ARABIC AUTHORS QUOTED}

'Abd al-Gabbār, Mugni = 'Abd al-Gabbār, Abū 'l-Hasan, Al-Mugni fí abwäb at-tauhid wa-'/-adl. Ed I al-Ibyārī Qāhıra, 1961.

'Abd al-Gabbār, Mutas̄ābıh = 'Abd al-Gabbār, Abū 'l-Ḥasan, Mutašăbıh al-Qur'ān. Ed. 'A.M. Zarzūr Qāhira, 1969

Aš'arī, Ibāna = al-Aṣ̌arī, Abū 'l-Haasan, Al-Ibāna 'an usūl ad-dıyāna Ed M ad-Dimašqi Qāhira, n d

Ašarī, Maq. = al-Ašarīi, Abū 'l-Hasan, Maqālāt al-ıslämıyyin Ed. H Rıtter. Wıesbaden, $1963^{2}$ (= Bıblıotheca Islamıca, I)

Bag̣dādi, Usūl = al-Bagdādi, 'Abd al-Qāhır b. Tāhır, Usūl ad-dīn. Ed Istanbul, 1928.

Bāq Tamh = al-Bāqillānī, Abū Bakr Mụ̣ b at-Tayyıb, Kıtāb at-lamhid Ed. R.J McCarthy Beyrouth, 1957.

Far. Alr = al-Fārābì, Abū Nasr, Al-Al/äz al-mustaimala fi 'l-mantıq. Ed M. Mahdī Baıı̄ūt, 1968

Far Fals All. = al-Fārābī, Abū Nasr. Falsafat Aflātün. Edd F Rosenthal/R Walzer London, 1943 (= Plato Arabus, vol. II).

Far. Ihs. = al-Fārābì, Abū Nașr, Ihṣā' al-'ulūm (Catálogo de las ciencias) Ed. trad A. González Palencias. Madrid/Granada, $1953^{2}$

Far. Sarh = al-Fārābī, Abū Nasr, Sarh li-kıtäh Arıstūtālis fì 'l-'ibāra Edd W Kutsch/ S Marrow. Beyrouth, $1971^{2}$

Fıhrist = b an-Nadim, Kıāb al-Fihrıst. Ed. G. Flügel, Leıpzıg, 1871/72 (Baırūt, 1964)

Gazz Asmā' = al-Gazzālī, Abū Hāmıd, Kitāh al-maqsad al-asnā šarh asmā' Allāh alhusnā Ed M. al-Kutubì. Qāhıra, 1324 A.H.

Gazz Maq = al-Gazzālī, Abū Ḥāmid, Maqāùd al-falāsıła Ed M.S al-Kurdì Qāhira, I331 A.H.

Gazz Mìyār = al-Gazzālī, Abū Hāmıd, Mìyār al-'ılm Ed M.S al-Kurdī. Qāhira, 1329 A.H

Gazz Mustasfà = al-Gazzālī, Abū Hâamıd, Al-Musłasfā mın illm al-usūl. Ed. M Muhammad. Qāhıra, 1937

Gazz Mıhakk = al-Gazzālī, Abū Hāmid, Mihakk an-nazar fi '/-manıı Edd M.B al-Halabì/M. ad-Dımašqi Miṣr, n d

Gazz Q Q̀stās = al-Gazzālī. Abū Hāmıd, Al-Qısıās al-mustaqim. Ed M ad-Dımašquĩ. Misr, 1900

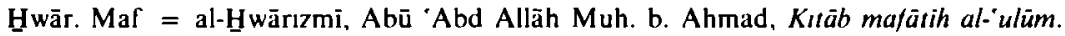
Ed. $G$ van Vloten Leiden, n.d.

Hunaın, Dıkr = Hunain ıbn Ishāq, Rısāla fi d̆ $ı$ kr mā turğıma mın kutub Gālinūs Ed trad G Bergstrasser Leipzig, 1925 (Nendeln, 1966)

b 'Aqīl, Rasāill = Ibn 'Aqīl, Abū 'l-Wafā' 'Alī, Rasā' ll fi '/-Qur'ān wa-țthāt al-harf wa-'s-saut raddan alä \%-As̈arıy'a Ed G Makdısı Bulleun d'Études Orıentales, 24, 1971, 55-96

b Anb Asr = Ibn al-Anbārī, Abū l-Barakāt, Asrār al-arabıyya Ed G.F Seybold Leıden, 1886

b. Anb Ins = Ibn al-Anbārī, Abū 'l-Barakāt, Kıāb al-ınsāf fì masā'll al-hnlāf baına 'n-nahwrlyina 'l-hasriyyina wa-'l-küfiyyina. Ed. G Weıl. Leıden, 1913

b Anb Lum = Ibn al-Anbārī, Abū 'l-Barakāl, Luma' al-adilla fi usūl an-naḥu Ed.

-A Amer Stockholm, 1963

b Anb Nuzha = Ibn al-Anbāri, Abū 'l-Barakāt, Nuzhat al-allhhā̄' fí lahaqāt al-udabā' Ed 'A Amer Stockholm, 1963 
b. Fār Șāḥ = Ibn Fārıs, Ahmad, Aṣ-Sāhibi fí figh al-lugia Ed. M. aš-Sū'īmi. Beyrouth, 1964.

b. Gın. Has. = Ibn Ginnī, Abū 'l-Fatḥ 'Uțmān, Al-Haşā̄iṣ. Ed. M.'A an-Nağgāàr. Qāhira, 1952.

b Hald. Muq = Ibn Haldūn, 'Abd ar-Rahmān ibn Muḥ, Al-Muqaddima. Baḡdād, n.d.

b. Hall. Waf. = Ibn Hallıkān, Sams ad-Dīn Ahmad b. Muh., Wafayāt al-äyän wa-anbä" $a b n a ̄ ' a z$-zamān. Ed. I. 'Abbās. Bairūt, (1968).

b. Hazm. Ihk = Ibn Hazm, Abū Muḥ. 'Alī, Al-lḥkām fị uṣūl al-aḥkām. Ed. A. Sāāir. Qāhira, n d

b. Hıš. Awd. = Ibn Hisām, Abū Mụ̣. 'Abd Allāh Gamāl ad-Dīn, Awdah al-masālik ılā Alfiyyat ıbn Mälık Ed. M M. 'Abd al-Hamid. Bairūt, $1966^{5}$.

b. Hıš Mugni = Ibn Hišām, Abū Muh. 'Abd Allāh Gamāl ad-Dīn, Muğnì 'I-labib an kutub al-äärih. Edd. M al-Mubārak/M A. Hamd Allāh Dimašq, 1969.

b. Madā', Radd = Ibn Madā', Abū 'l-'Abbās Aḥmad, Kitāb ar-radd 'alā 'n-nuhāt. Ed S. Daif. Qāhıra, 1947.

b Murt Tab = Ibn al-Murtaḍā, Ahmad b Yahyā, Tahaqāt al-Mu'tazıla. Ed. S. Diwald-Wilzer Beyrouth, 1961

b. Sıkk. Tahd̆. = Ibn as-Sıkkī, Abū Yūsuf Ya'qūb, Kanz al-huffāz fi tahdilb al-alfāz. Ed L Cheikho. Beyrouth, $1896-8$ (reprint, n d.).

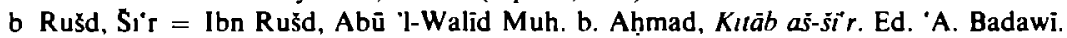
1n: Badawi, 1953.

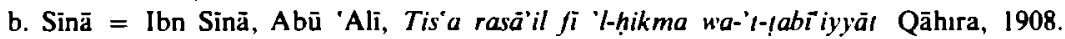

b Siñā, Sı'r = Ibn Sīnā, Abū 'Alī, Fann aś-šs'r Ed. 'A. Badawi in: Badawī, 1953

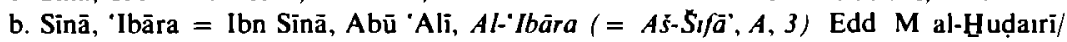
I. Madkūr. Qāhira, 1970

b Suwār = Ibn Suwār, al-Hasan, notes on Artstotle's 'Categorıae', edıted by Kh. Georr in. Georr, 1948 (cl chapter VI, note 38)

b. a Ușaıbìa = Ibn Abì Usaıbìa, 'Uyūn al-anbā' fi tabaqāt al-atıbhā'. Ed A. Müller. Qāhıra, 1884.

b $\mathrm{Ya}^{\mathrm{i}} \mathrm{i} \mathrm{S}=$ Ibn Ya î̀, Muwaffaq ad-Dīn, Sarh al-Mufassal Ed G Jahn. Leipzıg, 1882-6.

Kındī, Rasā’̀l = al-Kındī, Abū Yūsư Ya qūb ıbn Ishãq, Rasā'll falsafiyya Ed Abū Rida. Qāhıra, 1950-3

Mas Murūğ = al-Mas'ūdi, Abū 'l-Hasan 'Alī, Murūğ ad-dahab. Ed Barbier de Meynard. Parıs, 1861-77 (Baırūt, 1965-74)

Mas Tanb = al-Mas'ūdī, Abū 'l-Hasan 'Alī, Kitäb at-tanbih r'a-'l-ıśräf. Ed M J. de Goeje Leiden, 1894 (Beyrouth, 1965)

Misk Tahḍ. = Miskawaıhı, Abū 'Alī, Tahdihb al-ahlāq. Ed. Beyrouth, 1966.

Mub Muqt. = al-Mubarrad, Muh. b. Yazid, Al-Muqtadab Ed. M 'A Udaına. Qāhira, 1965-8

Plac Phıl = Qustä h Lüqä's Arahıc translation of the 'Plactia Phılosophorum'. Ed trad. H Daıber Saarbrucken, 1968

Qıftī, Ta'rīh = al-Qıfīi, Gamāl ad-Din, Ta'rih̆ al-ḥukamā' Ed J. Lippert Leıpzig, 1903

Qiftī, Inbāh = al-Qıftī, Gamāl ad-Dīn, Inbāh ar-ruuāt 'alā anhāh an-nuhāt Ed. M.A. lbrāhīm Qāhıra, 1369, A H.

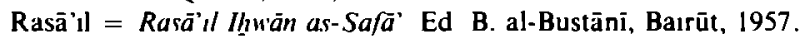

Rāzì, Maf. = ar-Rāzì, Fậr ad-Dīn, Majätịh al-gaıb Ed 'A. Muhammad. Qāhıra, n.d.

Rāzí, Opera phılosophıca = ar-Rāzi, Muh. b Zakariyyā, Opera philosophıca. Ed. P Kraus. Qāhıra, 1939 (Baurūt, 1973, without mentıon of the editor).

Rumm Sarh = ar-Rummāni, "Ali b. 'Tsā, Sarh $l$-Kıtäh Sibawaihı (quoted extensıvely In Mubārak, 1963)

Sahr Milal = aš-Šahrastāni, Kıtāh al-mılal wa-'n-nıhal. Ed. Cureton. London, 1842-6 (Qāhıra, 1948).

Sıb Kıt. = Sībawaıhi, $A l-K ı a ̈ b$ Būlāq, 1316 A H (reprınt Bag̀dād, n d) 


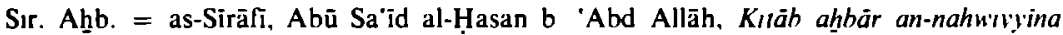
'l-hasriyyina Ed. F Krenkow. Parıs/Beyrouth, 1936.

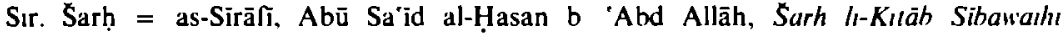
(in margıne Kutāb Sibuwathı).

Suy. Ašb. = as-Suyūīi, Galāl ad-Dīn, Al-Ašbāh na-'n-nazā'ir. Haıdarabād, 1359 A.H

Suy. Bug̀ya = as-Suyūtī, Galāl ad-Dīn, Bugvat al-nu'ät fi lahaqāt al-lugannıỵina wa-'n-nuhāò Ed. M A Ibrāhīm. Qāhıra, 1964-5.

Suy. Iqıı = as-Suyūịi, Galāl ad-Dīn, Kıāh al-ıqırāh fi usūl an-nahn Haidarabād, 1359 A H.

Suy. Muzh = as-Suyūti, Galāl ad-Dīn, $A l$-Muzhır $f i$ 'ilm al-luga Qāhıra, 1325 A.H.

Ta'l Mă̆. = Ta"lab, Abū "l-Abbās Ahmad b. Yahyā, Maḡälis Ta'lab. Ed. 'A M Hārūn Qāhıra, 1960²

Tauh Imtā' = at-Tauhīīi, Abū Hayyān, Kitāb al-ımtä’ wa- 'l-mu'ānasa. Edd. A. Amin/ A. az-Zain. Qãhira, 1939-44.

Tauh Muq. = at-Tauhīdī, Abū Hayyān, Al-Muqābasāt. Ed $\mathrm{H}$ as-Sandūbī Qāhira, 1929

'Ukb. Mas. = al-'Ukbarī, Abū 'l-Baqā', Masā'll hailäfiyya fí 'n-naḥu'. Ed. M $\underline{\mathbf{H}}$ al-Ḥalwānì. n p, n d

Yūḥ. b Mās. Nawādir = Yūhannā b Māsawaıh, An-Nau'ādır a!-ḷbbblyya. Ed P Sbath Qāhira, 1934.

Zağğ Amālī = az-Zağğāḡì, Abū 'l-Qāsım, Al-Amāli Ed. 'A. Hārūn. Qāhıra, 1382 A.H.

Zağğ. Gum = az-Zağğāğì, Abū 'l-Qāsim, Al-Gumal. Ed. M. Ben Cheneb. Parıs, 1957

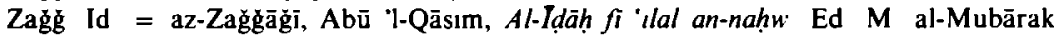
Qāhira, 1959

Zağǧ. Lām. = az-Zağğāḡì, Abū 'l-Qāsım, Kıtāb al-lāmāt. Ed. M. al-Mubārak Dımašq, 1969.

Zağğg. Mag̉. = az-Zağğāğì, Abū 'l-Qāsım, Mağālis al-'ulamā' Ed. 'A. M. Hārūn. Kuwait, 1962

Zam Ahāḡī = az-Zamaȟšari, Abū 'l-Qāsim Mahmūd b. 'Umar, Al-Ahāği 'n-nahwyyya Ed. M. al-Hadari. Hamā, 1969.

Zam. Muf. = az-Zamahnšarī, Abū 'l-Qāsim Mạ̣mūd b 'Umar, Kıtāb al-mujassal fi 'n-nahw. Ed. J P. Broch. Christianıe, 1897.

Zub. Tab. = az-Zubaıdī, Abū Bakr, Kı̈āb tahaqã an-nahwtyyina. Ed. F. Krenkow. Rıvısta degli Studi Orıentali, 8, 107-56.

\section{GREEK AUTHORS QUOTED}

Stoic fragments are quoted from Stocorum Veterum Fragmenta (SVF) edited by J. von Amim, Stuttgart, 1968 (editio stereotypa from the first edition, 1903). In quotations from SVF two numbers indicate: volume, fragment; three numbers indicate: volume, page, line.

Commentaries on Aristotle's writings are quoted from Commentaria in Artstotelem Graeca, edited by the Academia Litlerarum Regia Borussica, Berlin, 1882-

Greek grammarians are quoted from Grammatici Graect, Hildesheim, 1965 (editio stereotypa from the edition Leipzig, 1883-1901).

Bekker, AG = I. Bekker, Anecdota Graeca. Leipzig, 1816

Diog. Laert. = Diogenis Laertu Vitae Phılosophorum. Ed. H S. Long. Oxford, 1966².

Greg. Cor. = Gregorios of Corinth, Peri suntáxeôs logoû. Ed. D. Donnet. Bruxelles/

Roma, 1967. 
Joh Dam = Johannes Damaskenos. Du' Sthuften des Johannes von Damashos I Instututio clementaris Capua philosophica (Dialectica) Ed. B Kotter Berlin, 1969 (= Patristische Texte und Studien, Band 7)

Plout de comm not = Ploutarchos, De commumitus notums Edd $\mathrm{M}$ Pohlenz $/ \mathrm{R}$ Westman. Leıpzig, $1959^{2}$ (= Plutarchı Moralia, vol VI, fasc 2)

Prokl Comment. = Proklos Diadochos. In Platonis Cratylum Commentarıa Ed G Pasquali. Leıpzig, 1908.

Sext Emp adv math = Sextus Empiricus, Adversus mathematicos Ed. transl R G Bury. Cambridge (Mass)/London, 1961

Tryph. frg. = Trvphonıs fragmenta Ed A. de Velsen Berlın, 1853 (Amsterdam, 1965)

\section{HEBREW AUTHORS QUOTED}

b Ganāh, Opuscules = Ibn Ganāh, Abū 'l-Walìd Marwān, Opuscules et tratés. Edd. J. et H Derenbourg. Parıs, 1880 (Amsterdam, 1969)

b. Ganāh, Sēfer = Ibn Ganāh, Abū 'I-Walìd Marwān, Sēfer harriqmā. Hehreu translatıon by Yehüdä hen Tıbhön. Ed M. Wilenski (reprinı Yerušalayım. n.d)

Kımhi, Mikhlol = David Kimhi, Mıkhlol. Transl W. Chomsky. New York, 1952.

\section{LATIN AUTHORS QUOTED}

Latın grammarians (except Charısıus) quoled [rom Grammatıc Latmi, edited by $\mathrm{H}$ Keil. Leıpzig, 1855-80.

August. dialect = Augustinus, De dialectica liber Ed J Pinborg; transl B Darrell Jackson Dordrecht/Boston, 1975 (= Synthese Historical Library, 16) (quolations are by chapter, page, and line in Crecelius' edıtion, S. Lucas, 1857).

Char. art. gramm. = Charisıus, Artıs grammatıcae librı V. Ed C. Barwick. Leipzig, 1964.

Quint. Instıt. orat = Quintılianus, Institutıones oratoriae libri primı capıta de grammatica $(I, 4-8)$. Ed. M. Niedermann Neuchâtel, 1947.

Varro, De L. L. = Varro, De Lingua Latina Ed. transl R.G. Kent. Cambridge (Mass.)/ London, 1958. 
ORIGINALS OF THE ARABIC AND GREEK TEXTS QUOTED IN ENGLISH TRANSLATION

- - هذه الصناعة تسمى باليونانية غرماطيتي وبالعربية النحو.

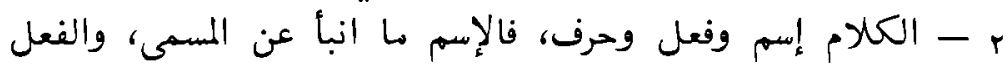

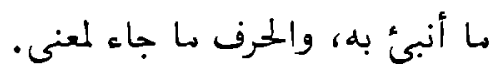

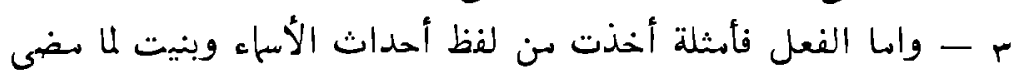
ولما يكون ولم يقع وبا هو كائن لم ينقطع . ع - الرفع عند أعحاب المنطق سن اليونانيين واو ناقصة وكذلك الضهم

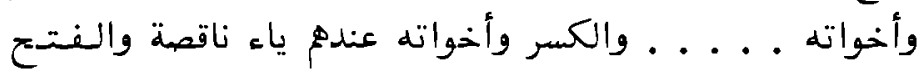
وأخواته عنده ألف ناقصة، وانه شئت قلت الوان واو الممدودة اللينة

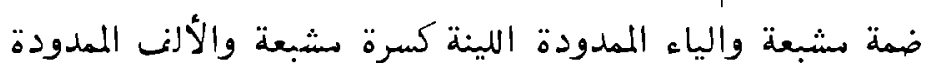
فتحة سشبعة.

ه - ألا ترى أن سن ستقدسي القوم سن كان يسمى الضمة الـواو

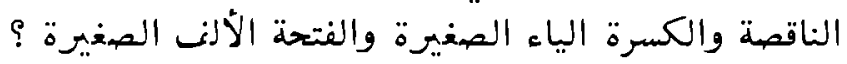
ד - وسئل الخليل عن الرفع لم جعل للفاعل ؟ فقال : الرفع أول

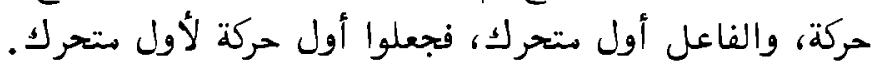

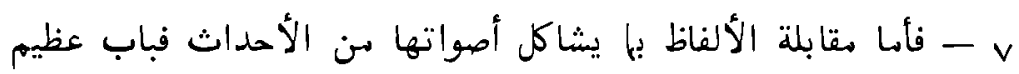

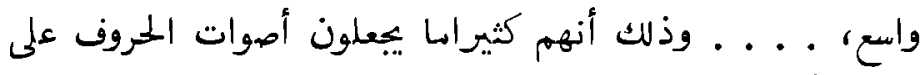
سمت الأحداث المعبر بها عنها فيعدلونها بها ويمتذونها ولها عليها.

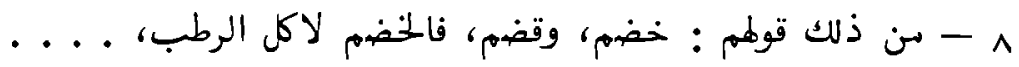

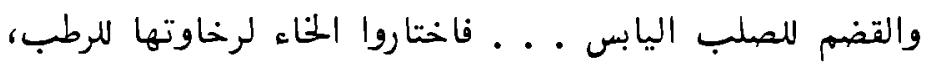

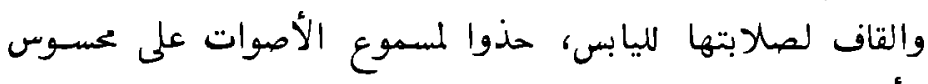
الأحداث.

q - والأصل في هذا الباب أن جنس الصوت قد يختلف الوجه الذي يحدث عليه، فقد يكون صوتا سفيدا غير مقطع، وقد يكون مقطعا في جنس واحد، وقد يكون سقطع في جنس على وجه يتصل تارة 
في الحدوث وينفصل أخرى، وقد بحدب على وجه لكون حرفا وحروفا. وفد يحدب على وجه لا يوصف بذلك، كصرو الباب،

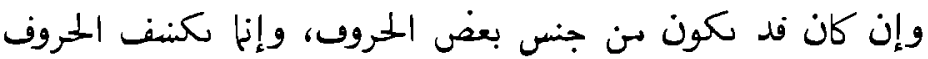
بأن يحدب الصوت في بنه وغنارج غخصوصة، كبند الفم وغبره.

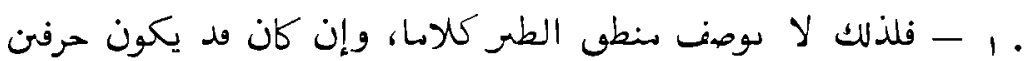

$$
\text { أو حروفا منظونة. }
$$

11

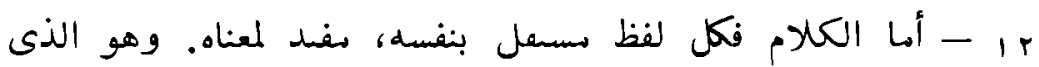

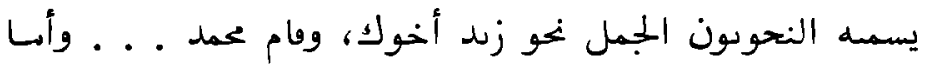

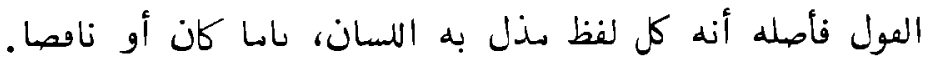

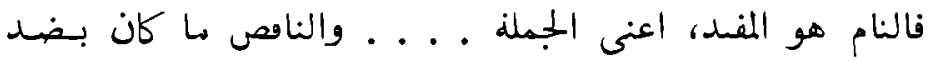
ذلك، نهو زيد، ومحمد، وإن، . . . . فكل كلام فول، ولبس كل

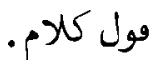

r r - فالكلم إسم وفعل وحرف جاء لمعنى لبس بآسم ولا فعل.

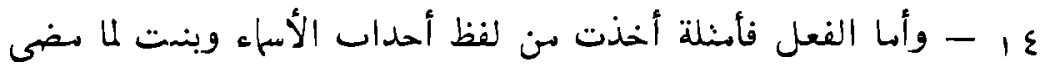

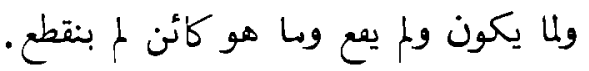
10 فوله في آخر الباب ولبس بآسم ولا فعل .

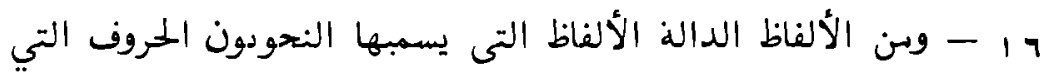

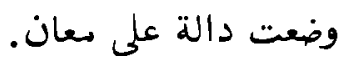

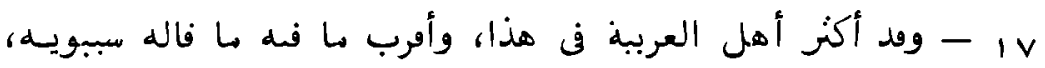

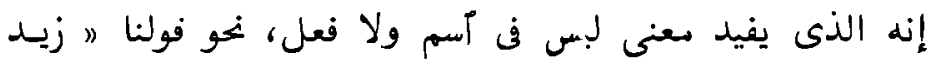

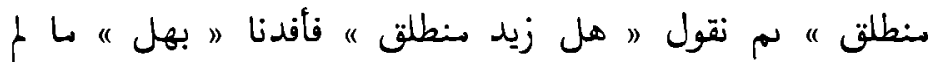

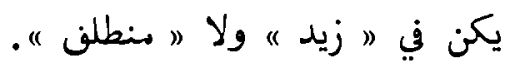

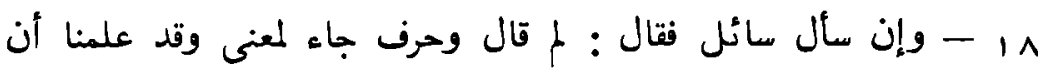

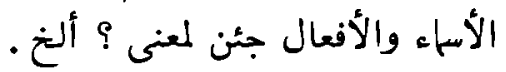
و - اللعب هو آسم طارئ على أسور لها أسم آخر. 
• r - الإسم ما كان واقعا على معنى، نحو رجل وفرس وزيد وعمرو وما أشبه ذلك.

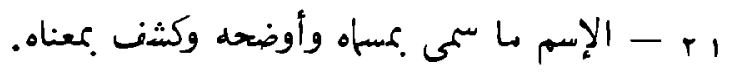

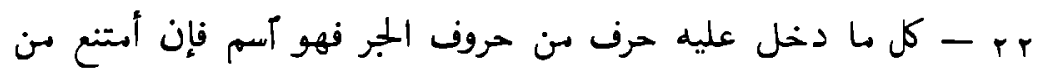
ذلك فليس بآسم . دمخ عليه

rr - فالمفردة سنها لـا هي ألقاب أعيان شثل زيد وعمرو وسنها ما يدل

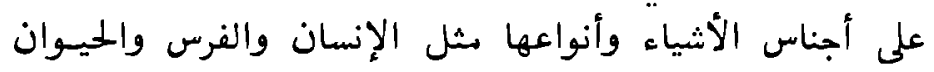

$$
\text { والبياض والسواد. }
$$

ع ب - الإسم ما دل على بعنى وذلك المعنى يكون شخصها وغير شخص.

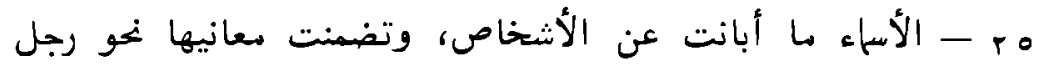
وفرس.

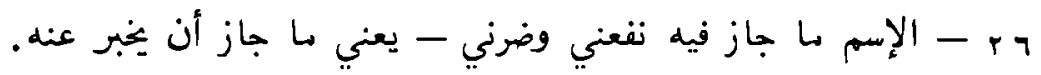

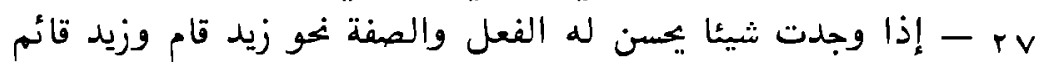

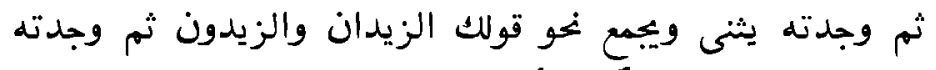

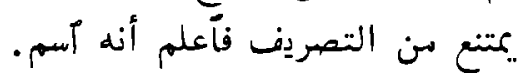

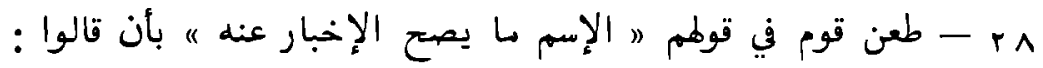

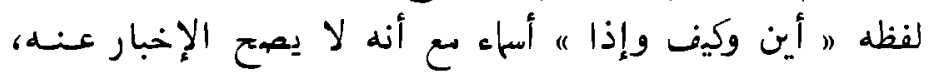

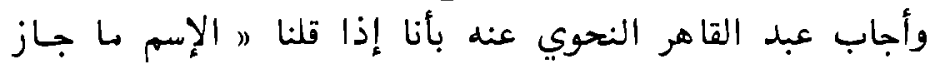

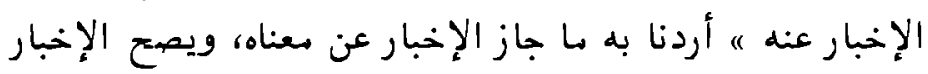

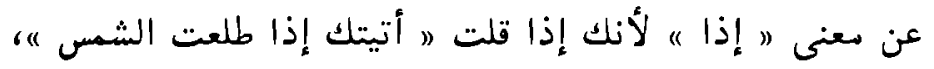

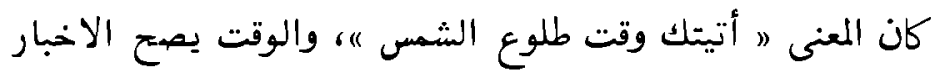

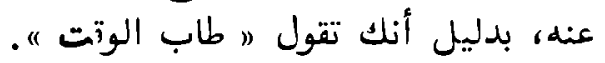

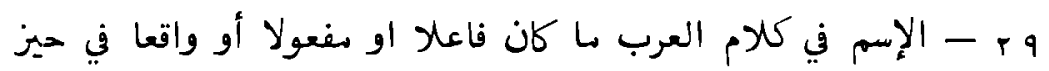

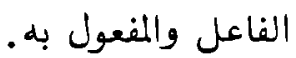
. - مالإسم با جاز ان يكون فاعلا او سفعولا. ابr - إن كل فاعل وكل سنفعل فهو جسم.

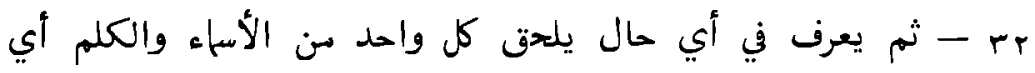


طرف فياتي أولا على إحصاء حال حال سن أحوال الأساء الموحدة

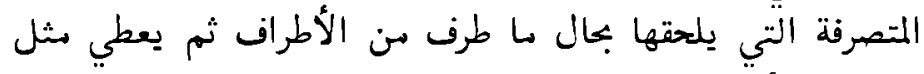

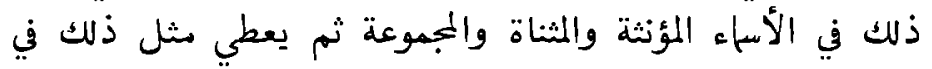

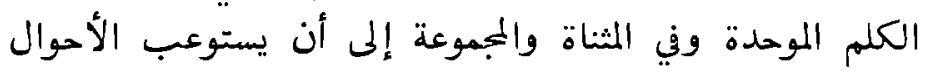

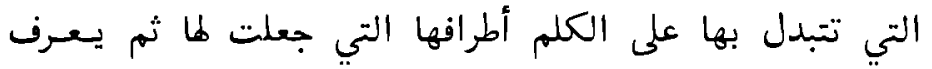

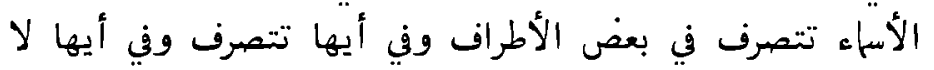

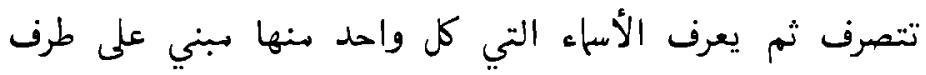

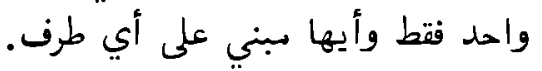

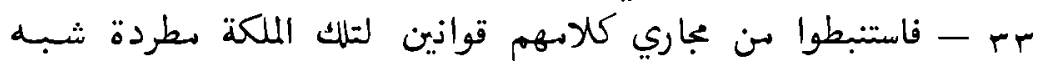

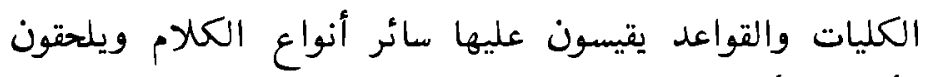
الأثباه بالأشباه.

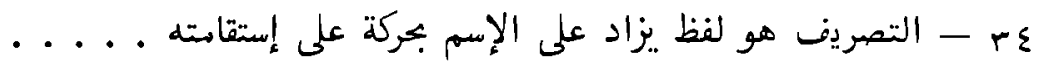

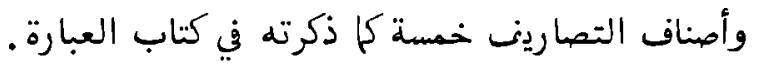

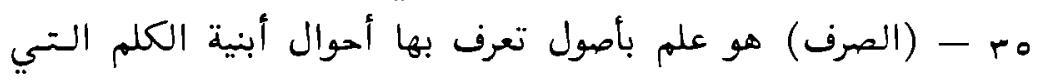

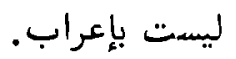

حب - (الصرف) هو معرفة أصل الملمة وزيادتها وحذفها وأبدالما.

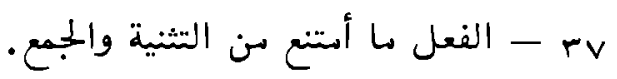

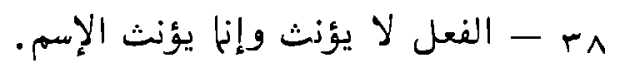

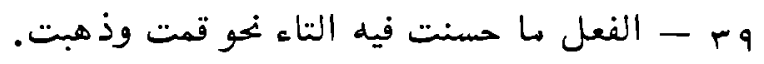
. ع - الفعل ما حسن فيه أسس وغدا.

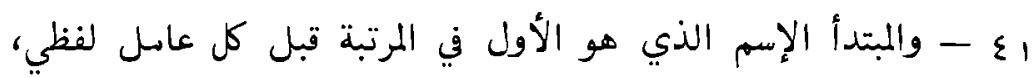

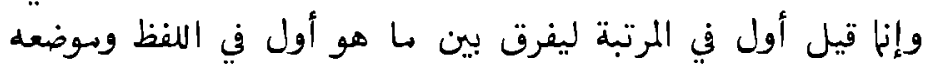

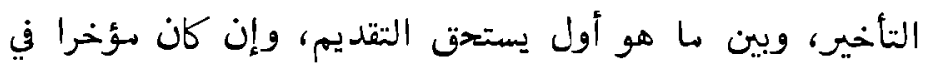

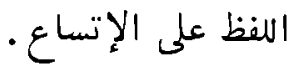

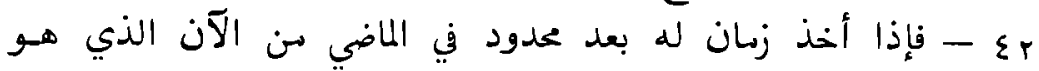

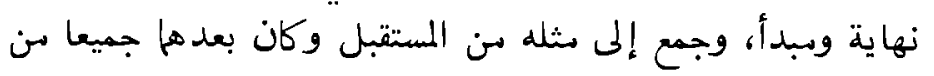


الآن الذي هو النهاية والمبدأ بعدا واحدا في الماضي والمستقبـل وجمعا جميعا كان ذلك الزبان هو الزهان الخهاضر.

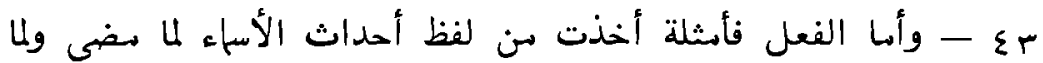

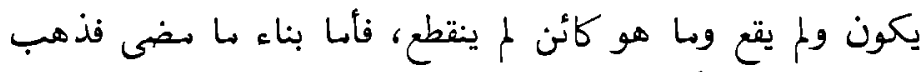

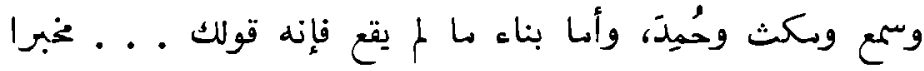

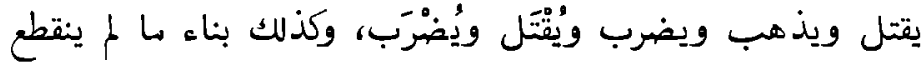
وهو كائن إذا أخبرت.

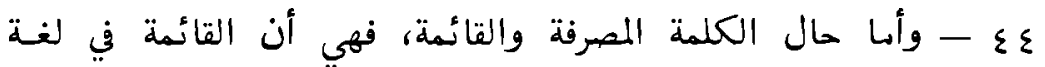
اليونانيين هي ها يدل على الحاضر، والمصرفة سا يدل على ولى أحسل

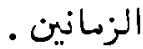

0ـ - . . . . . بين ما هي سنها مصادر وهي التي سنها تعمل الكلم

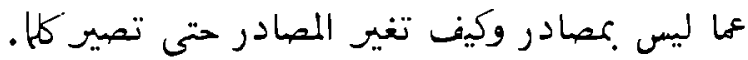

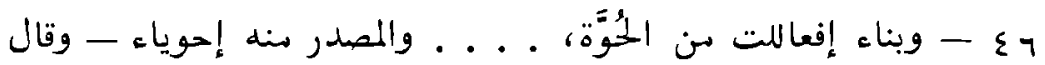

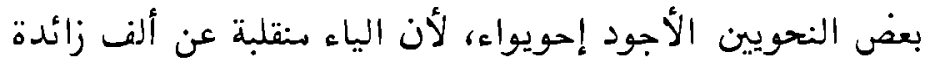

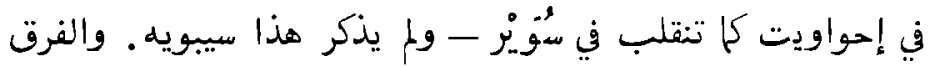

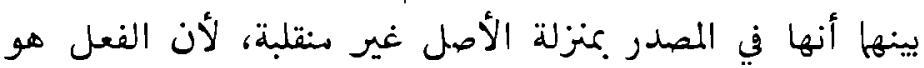

$$
\text { المأخوذ نس المعهدر. }
$$

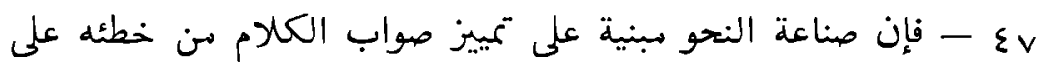

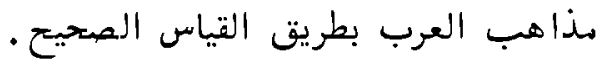
ی ع - وأنا الكتب التي ينحو بها نهو أعحاب التجارب فوجدت ثلاث

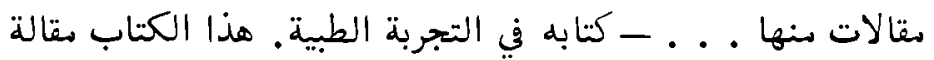
واحدة يقتص فيها حجج أعحاب التجارب وأمعاب القياس بعضهم على بعص. وترجمته أنا سنذ قريب إلى السريانية لبختـيسشـوع .

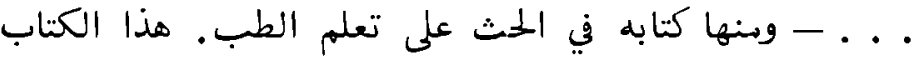
أيضا سقالة واحدة ونسخ فيه كتاب سينوذوطس وهو كتاب حسن نافع ظريف. ترجمته أنا إلى السريانية لجبريل وتوجمه إلى ولى 
العربية حبيش لأحمد بن سوسى . . . - وبنها كتابه في جمل التجربة. هذا الكتاب أيضا سقالة واحدة. ونستخه في كتبي ولم

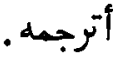

१ ع - ما إجتمع الأطباء عليه وشهد له القياس و عضهته التجربة فليكن ! • - - أحببت أن أعلم كيفية إدراك معرفة الطب ومأخذ أصله، أذلك

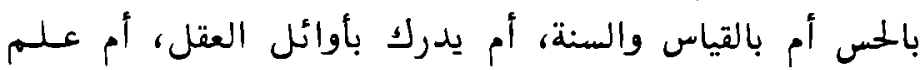
ذلك وطريقة يدرك عندكم سن جهة السمع ؟ ألخ . ا 0 - (القياس) عبارة عن تقديو الفرع بهك الأصل .

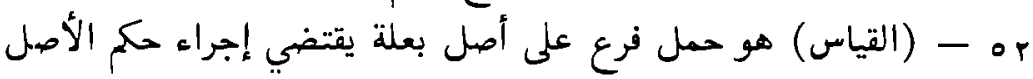
على الفرع مه - فأما سن تكلم بن العاهة بالعربية بغير إعراب فيفهم عنه، فإنا ذلك في المتعارف المثهور والمستعمل المألوف بالدراية. ولو إلتجأ أحده إلى الايضاح عن سعنى ملتبس بغيره، سن غير فههد بالإعراب، لم يمكنه ذلك. عه - إن العرب نطقت على ستجيتها وطباعها. وعرفت سواقع كلإهم، وقام في عقوها علله، وان لم ينقل ذلك عنها، وإعتلنت أنا بمان

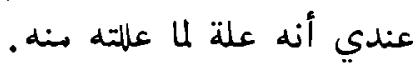
00

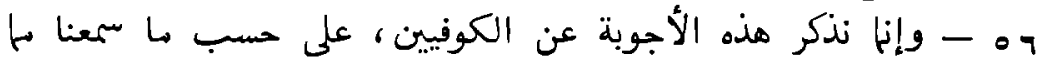

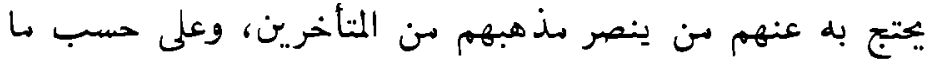

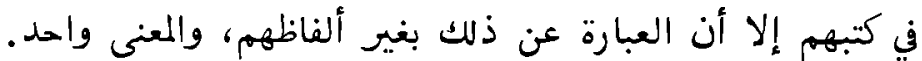

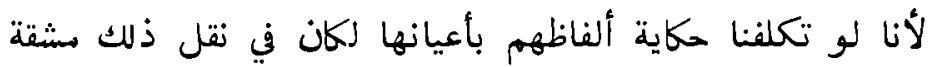

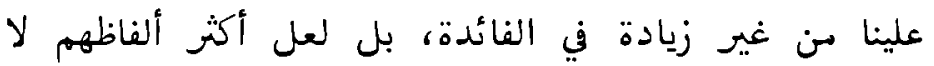
يفهمها من لم ينظر في كتبهم . vo - وانه رام نحو هؤلاء الكوفيين ، وانهم يُصلون على الرواية فإذا إختلفوا رجعوا إلى الكتبـ. 


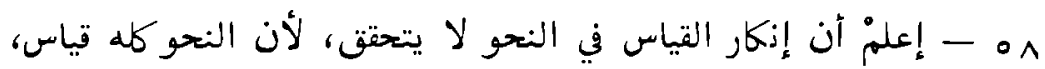

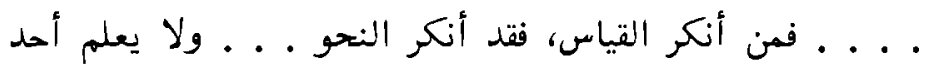

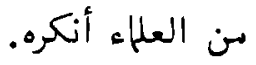

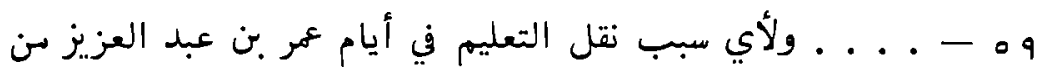

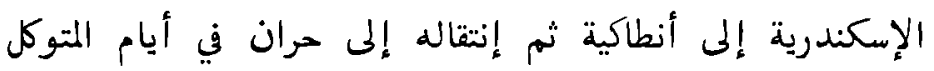

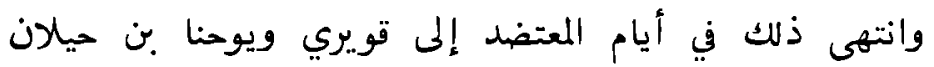

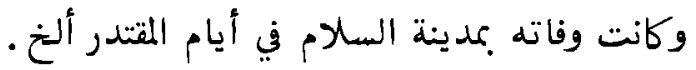

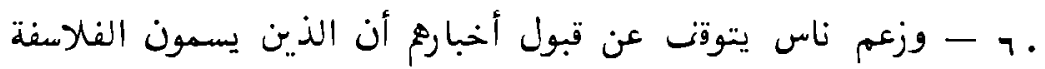

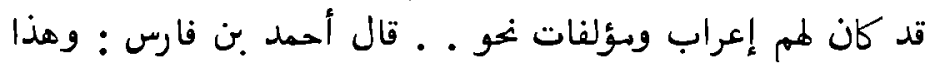

$$
\text { كلام لا يعزَج على سثله. }
$$

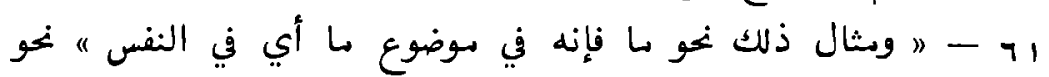

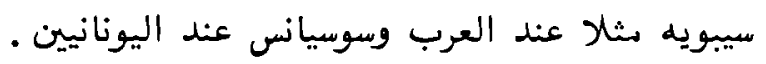

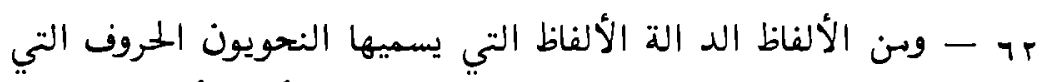

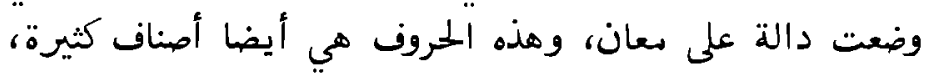

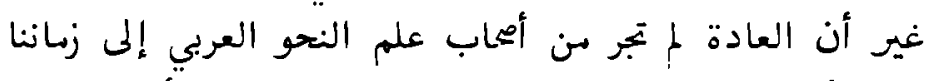

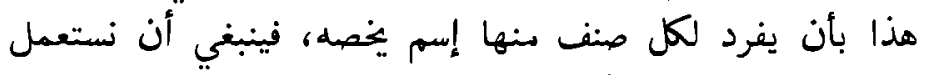

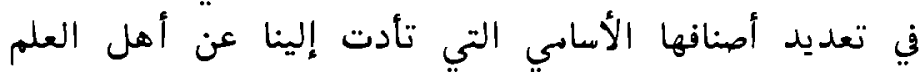

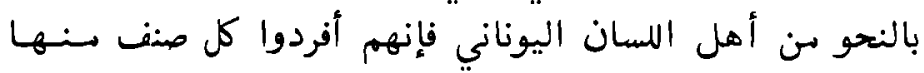

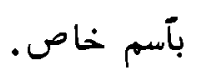

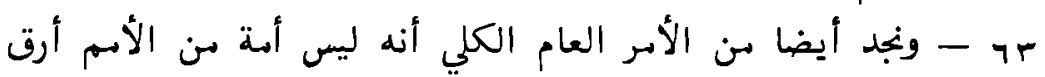
فطنة وأظهر حكمة من اليونانيين .

ع - - والنحو سنطق ولكنه مسلوخ عن العربية والمنطق نحو ولكنه سفهوم بالنغة.

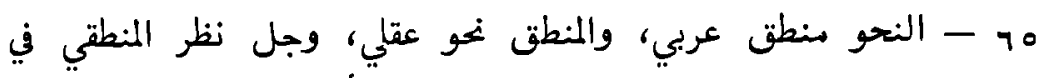

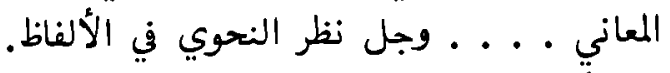

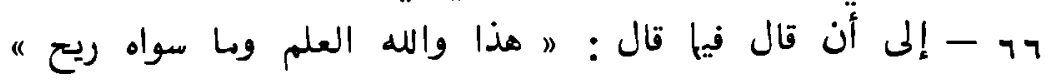

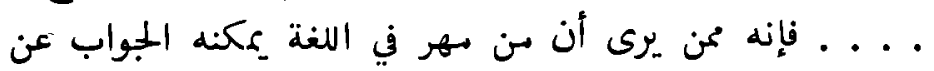

$$
\text { جميع ما يسال عنه. }
$$


TV - وليس هذا سن ألفاظ النحويين ولا أوضاعهم، وإنا هو سن كلمام

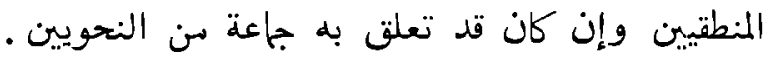

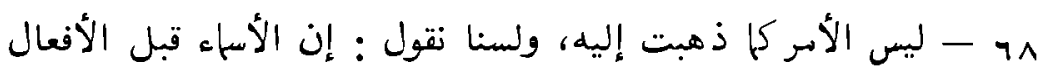

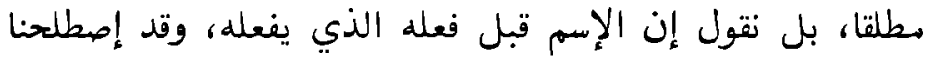

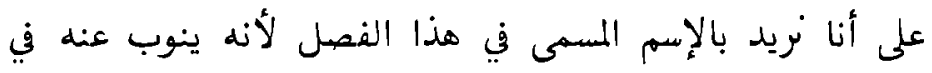

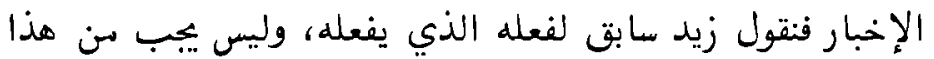

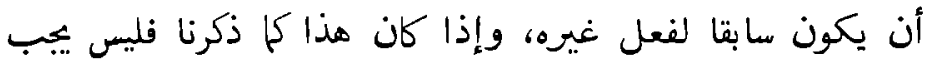

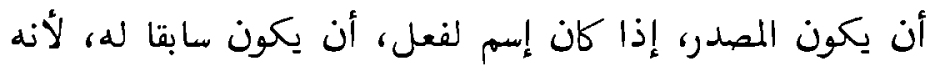

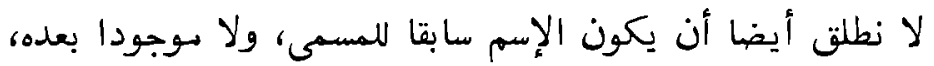

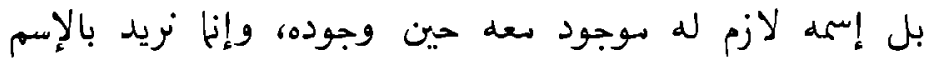

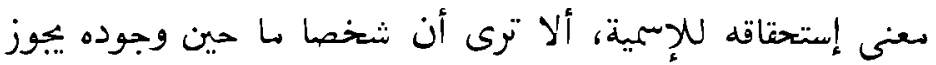
أن نسميه زيدا، ثم تنقله عنه فتسميه بكرا، ثم تنقله عنه فتسميه التهيه

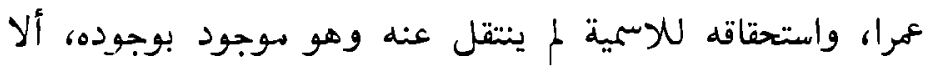
ترى أنه يقع عليه شيء ولا يفارقه، فهو شيء على كل الأحوال.

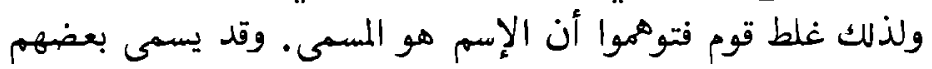

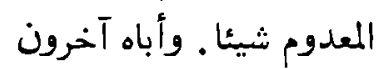

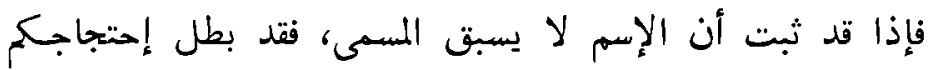

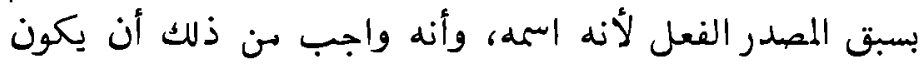
قبله سابقا له.

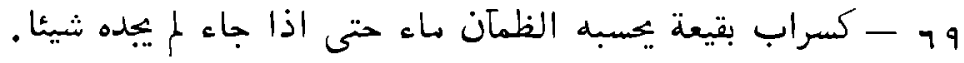

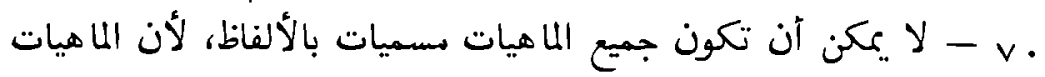

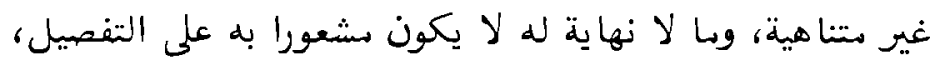
وبا لا يكون سشعورا به استنع وضع الاسم بازائه.

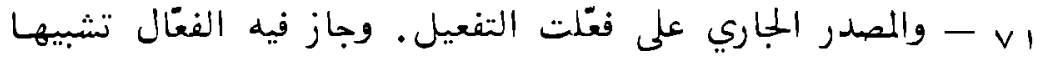

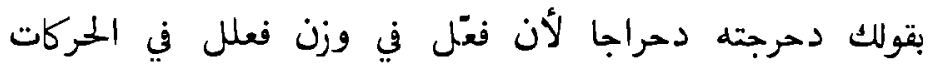

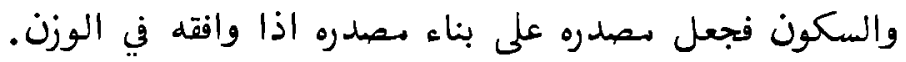


ORIGINAL TEXTS

217

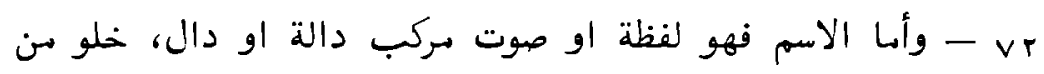

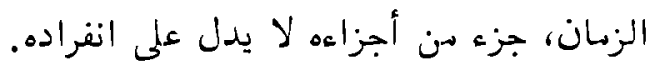

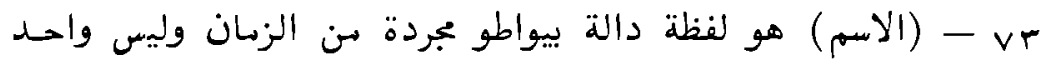
هن أجزائها دال على انفراده.

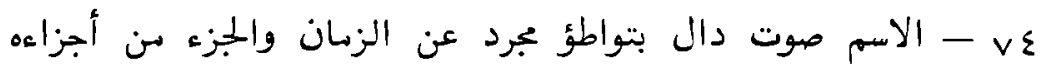

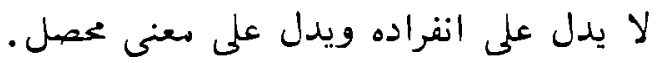

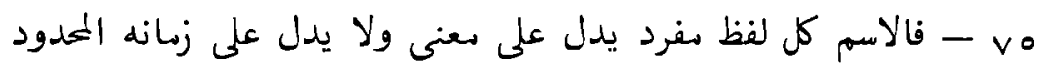

كزيد وخالد.

ح v - وأسا الاسم فهو صوت او لفظة تدل بانفراد ها على معنى خلو سن

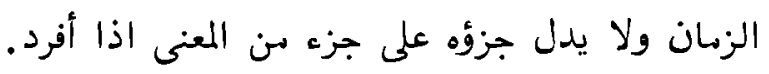

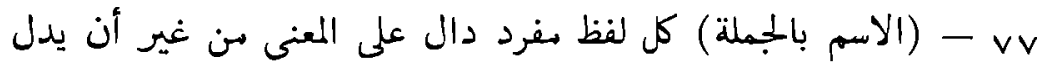

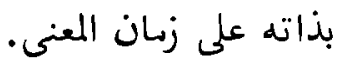

هی - الاسم صوت موضوع دال باتفاق على معنى غير مقرون بزمان.

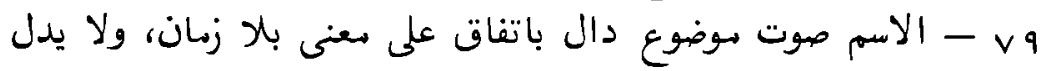

جزؤه على شيء سن معناه.

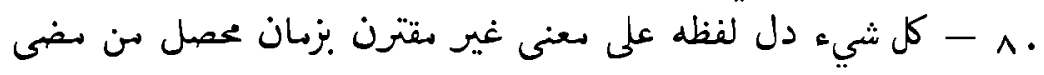

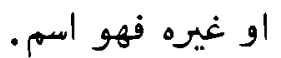

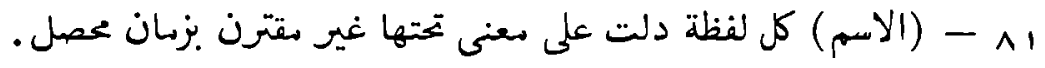

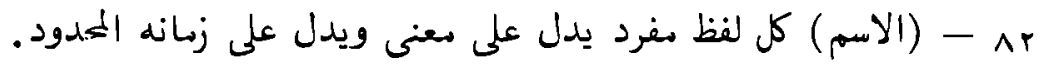

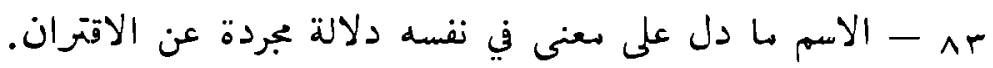

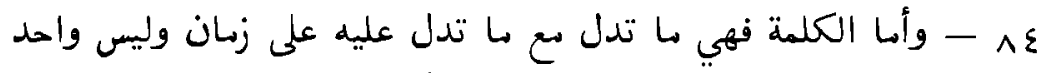

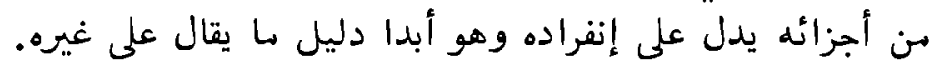

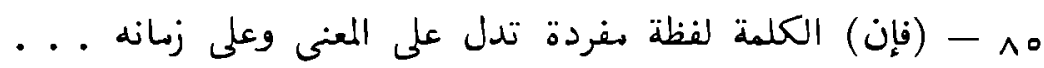

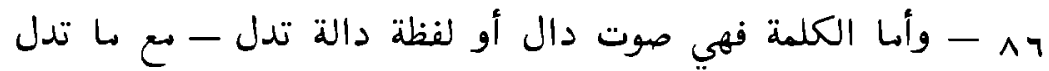

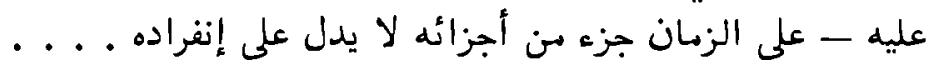

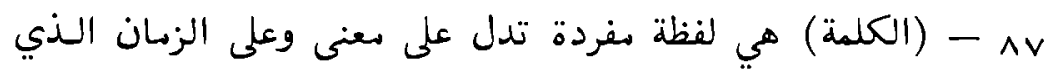

ذلك المعنى سوجود فيه. 


$$
\begin{aligned}
& \text { ^^^ - (الفعل) ما دل على حدث، وزنان ماض أو سستقبل } \\
& \text { १ی - الفعل ما دل على اقتران حدث بزهان. }
\end{aligned}
$$

• و - الفعل كلمة دالة على ثبوت المصدر لشيء غير هعين في زبان

مeن

1 - الإسم لفظ دال على ساهية، والفعل لفظ دال على حصيول

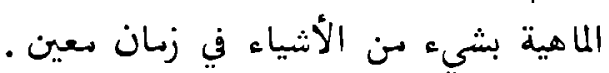

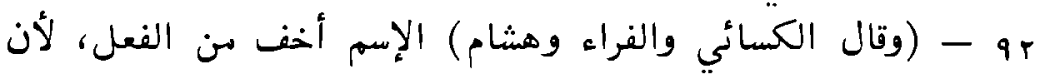
الإسم يستتر في الفعل، والفعل لا يستَت في الإسم.

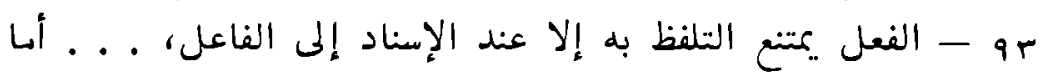

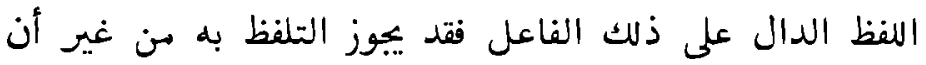
يسند إليه الفعل.

ع - والكلام يفعله المتكلم ويوجده بعد أن لم يكن، فهو فعل هن أفعاله.

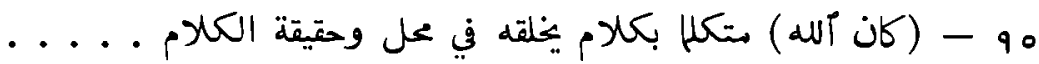
أحوات سقطعة وحروف سنظوسة والمتكلم سن فعل الكام لا دن

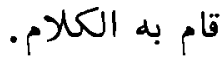
و و - فصل في أن حقيقة المتكلم أنه وجد الهلام سن جهته وبكسب قصده وإرادته.

q V - والقراءة عنده والتلاوة والكتابة غخلوقة، والقرآن صفة قائمة في

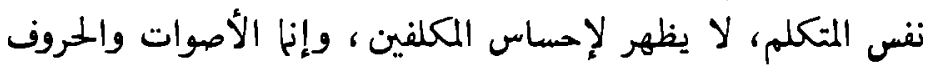

\section{حكايتها.}

^و - ألا توى أن المتكلم سنا إنا يستحق هذه الصفة بكونه ستكلا لا لا

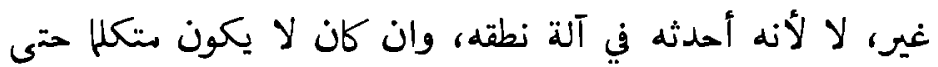

$$
\text { يحرك به آلات نطقه ؟ }
$$

9 - فليس سا يقوله أهل العريية، من أن الكلام إسم وفعل وحرف

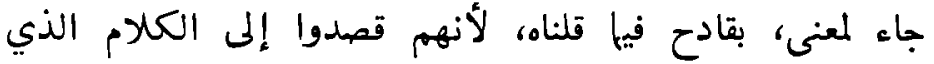
حددناه فصنفوه أصنافا، ولم يدفعوا كون جميعه حروفا هنظوبـة فئة 


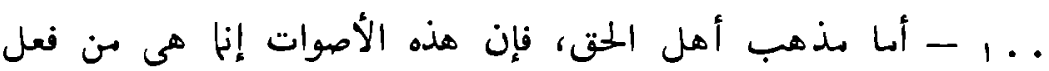

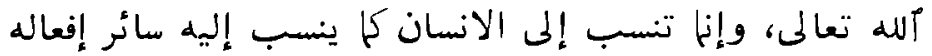
الإختيارية.

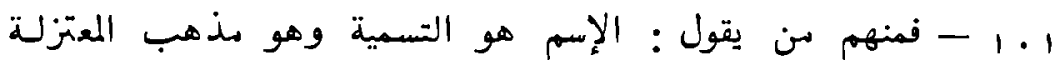

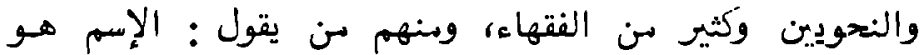
المسمى، وهو مذهب الأشعري.

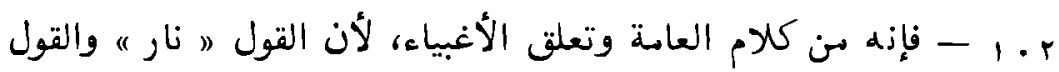

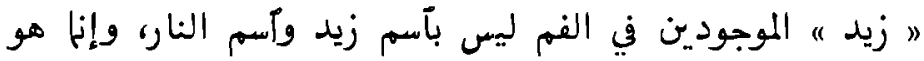

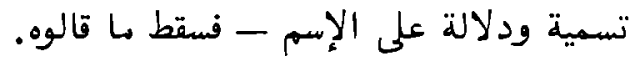
ז. - - وييوز أن يكون أقام الأسياء بقام المسميات بها في الإخبار عنها،

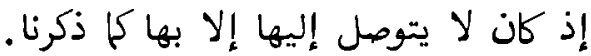

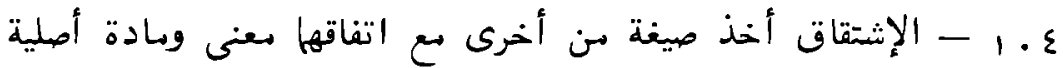

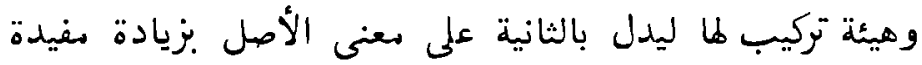
لأجلها اختلفوا حروفا أو هيئة.

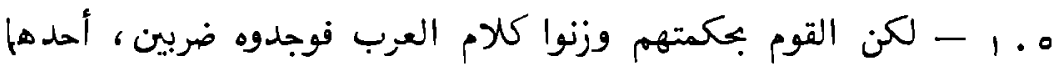

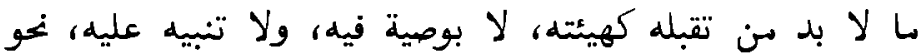

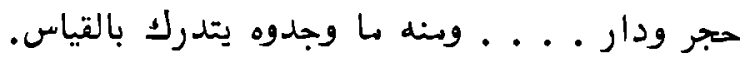

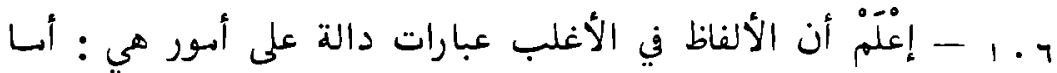

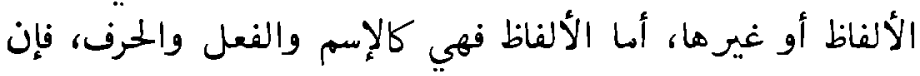

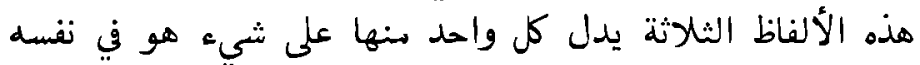

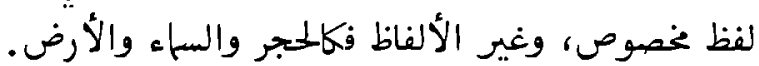

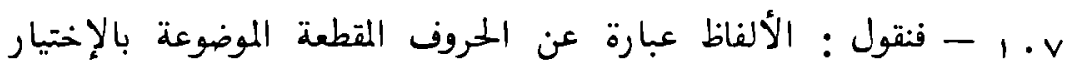

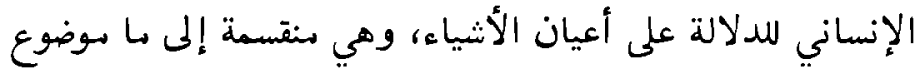

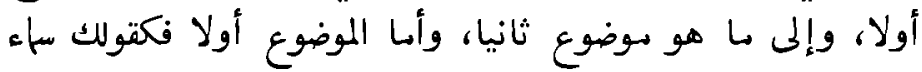

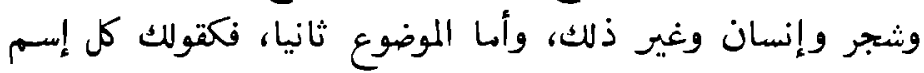

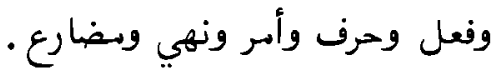

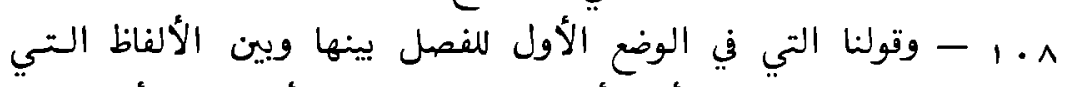
في الوضع الثاني لأن الألفاظ التي في الوضع الأول هي الألساء ـ. . 
التي أوقعت أولا على الأمور وصيرت سات وعلانات تدل عليها

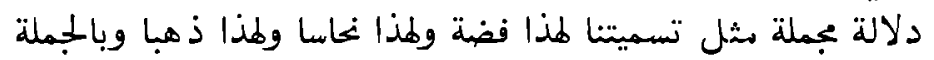

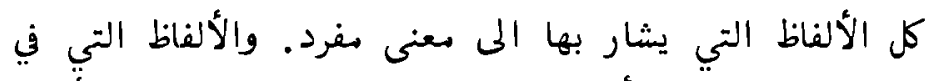

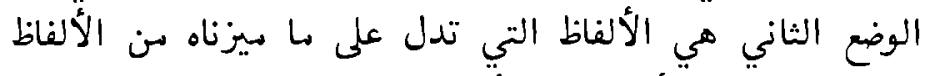

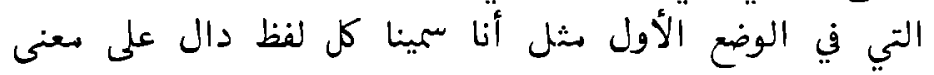
عصل مجرد سن الزهان . . . وكلا يدل معا يدل عليه على زمان

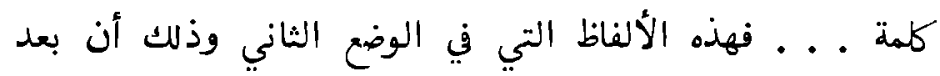

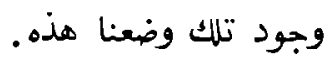
و . 1 - ثم فٔص بعد ذلك هل تلك الصناعة هي صناعة علم اللسـان

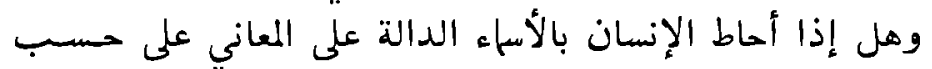

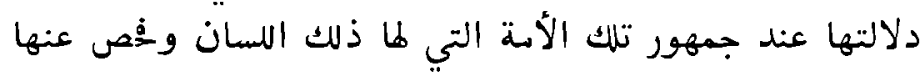

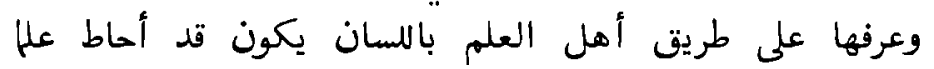

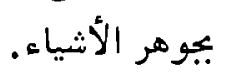

• 11 - واختلفوا بأن العلم بالصفة إذا كان ضروريا كان العلم بالموصوف أيضا ضروريا، فلو خلق آلله تعالى العلم في قلب العاقل بأنه

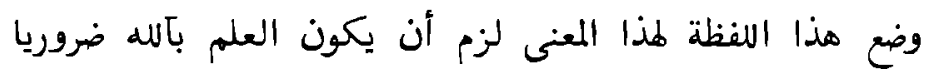
وذلك يقدح في محة التكليف. 111 - 11 الإسم سمة توضع على الشيء يعرف بها.

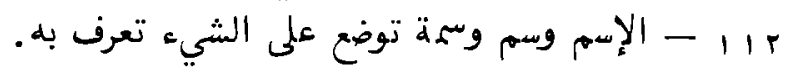
r 1 ا - وذلك كأن يتمع حكيان أو ثلاثة فصاعدا، فيحتاجوا إلى الابانة عن الأثياء المعلونة، فيضعوا لكل واحد سنها سمة ولفظل، إذا ذكر عرف به سا سساه، ليمتاز سن غيره، وليغنى بذكره عن إحضاره

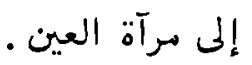
ع 1 - وكيف يصت أن يقال : إنت فلانا يتكلم هن غيو فكر، إن كان الهلام هو الفكر ؟ و ه - إن المصادر أجناس المعاني كا غير ها أجناس للأعيان، نحو رجل وفرس وغلام ودار وبستان . . . 


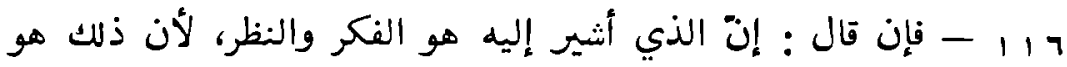

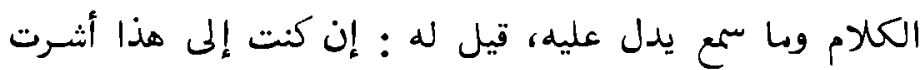

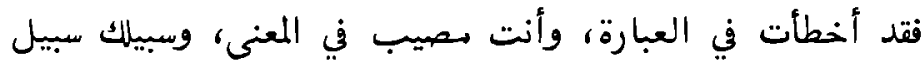

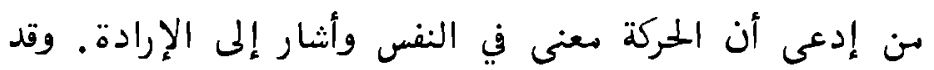

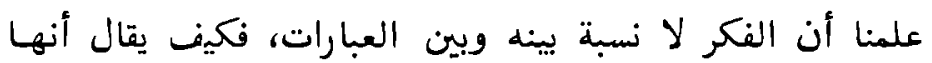

$$
\text { دالالة عليه ؟ }
$$

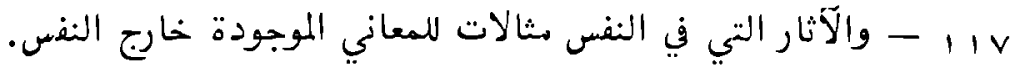

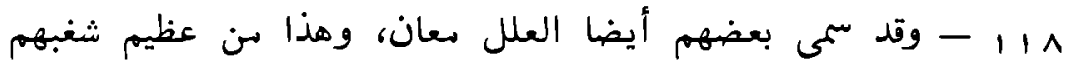
وفاسد شتعلقهم وإنا المعنى تفسير المغظ.

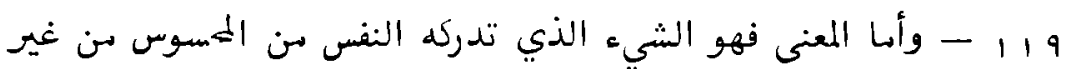

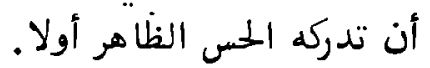

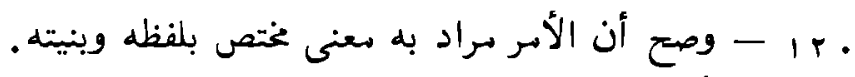

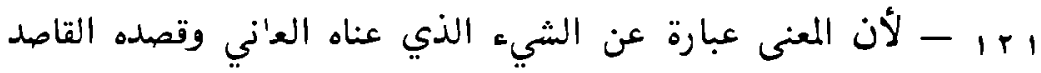




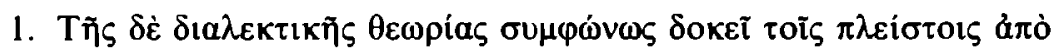

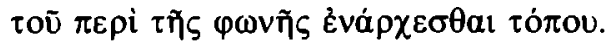

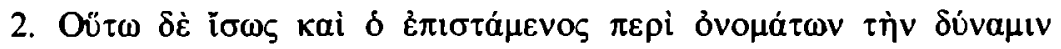

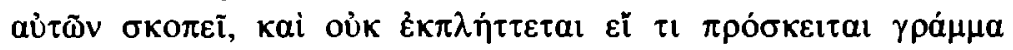

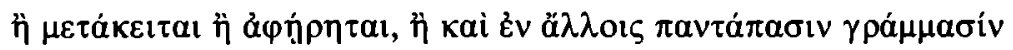

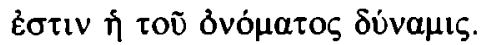

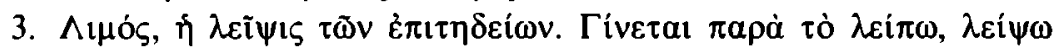

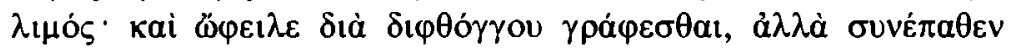

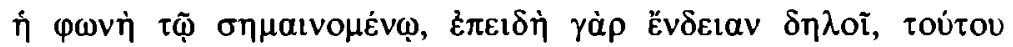

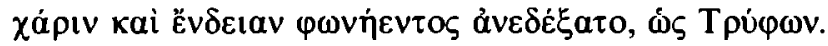

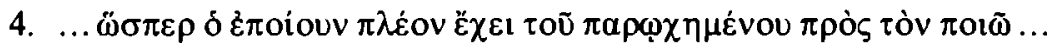

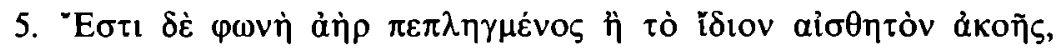

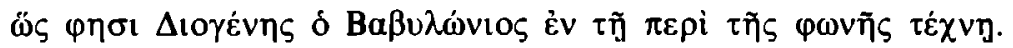

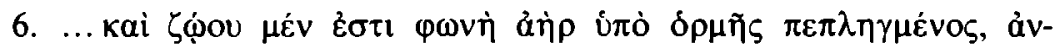

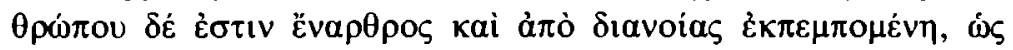

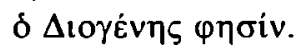

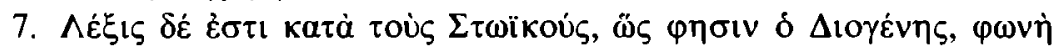

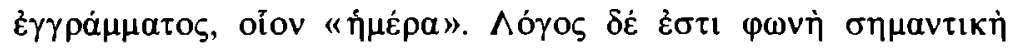

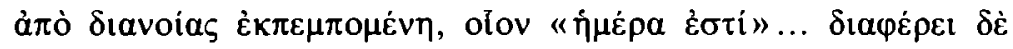

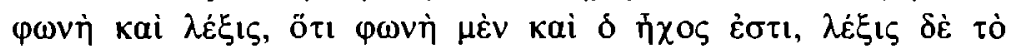

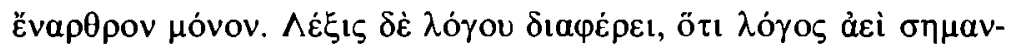

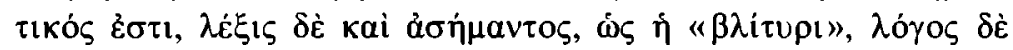
oủ $\alpha \mu \tilde{\omega} \zeta$.

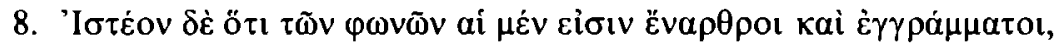
á ai

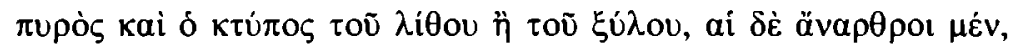

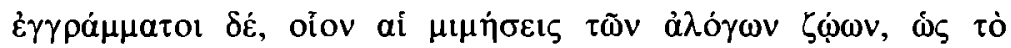

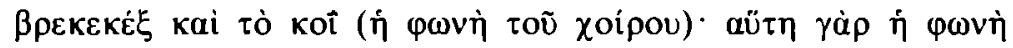

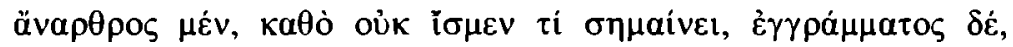

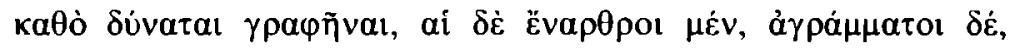

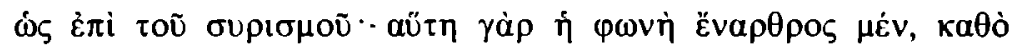

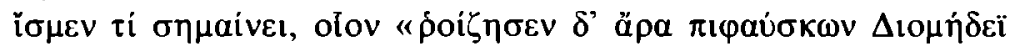

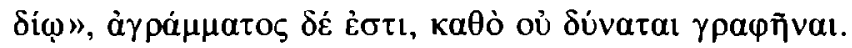

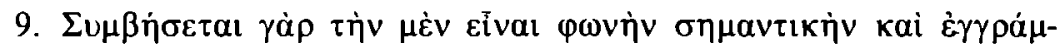

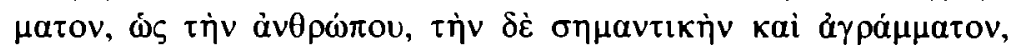

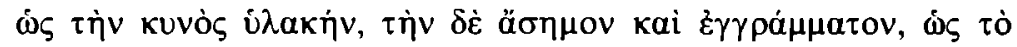

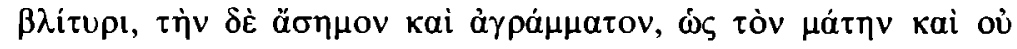




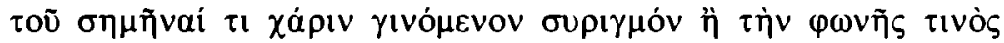

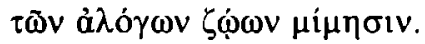

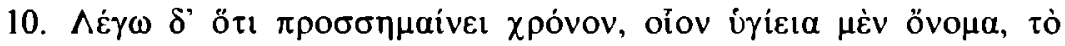

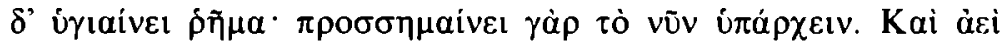

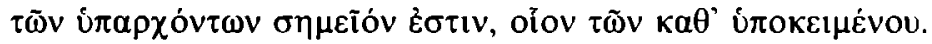

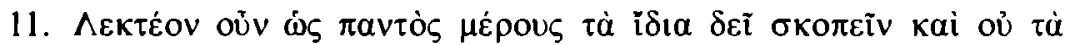

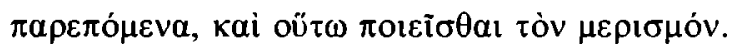

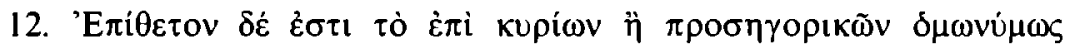

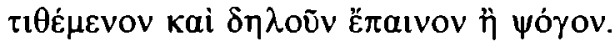

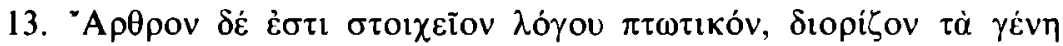

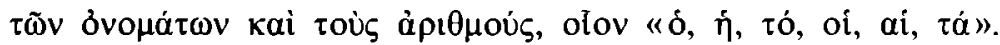

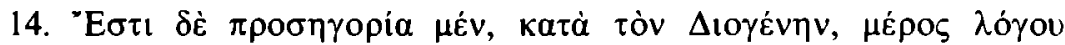

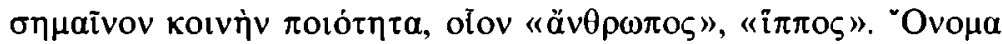

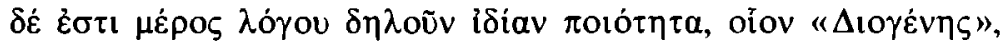

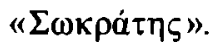

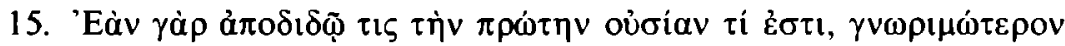

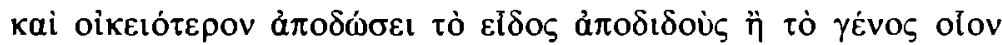

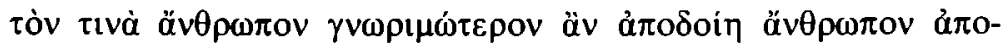

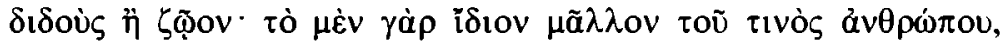

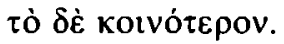

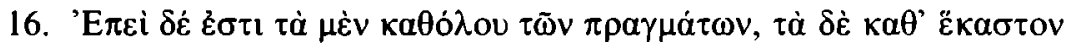

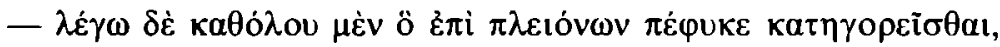

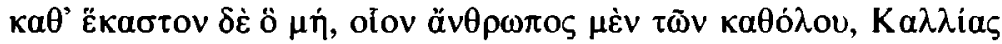

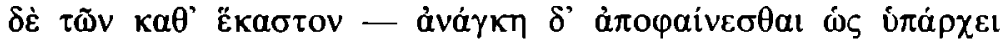
$\tau \imath \grave{\eta} \mu \dot{\eta}$.

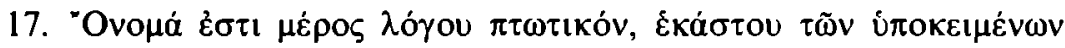

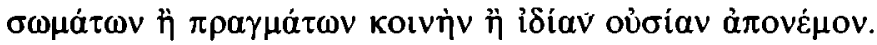

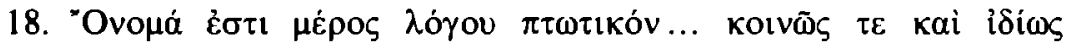

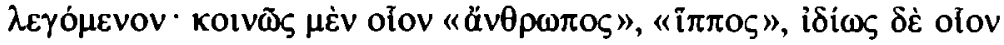

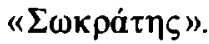

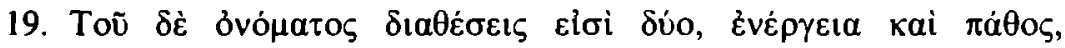

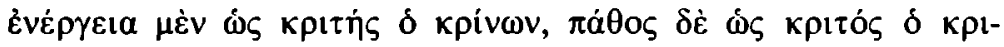
vó $\mu \varepsilon v o \zeta$.

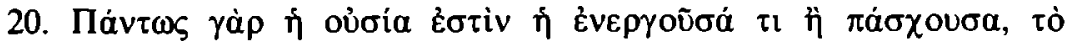

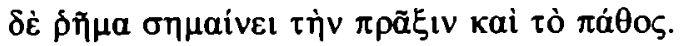

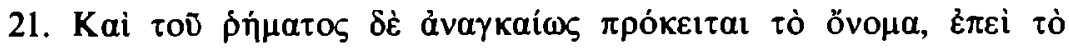

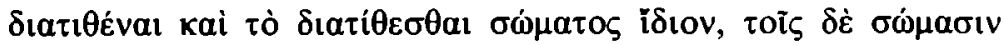

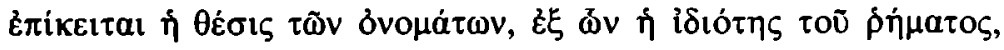

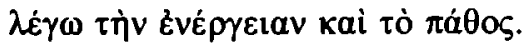




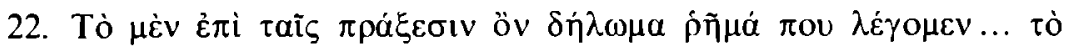

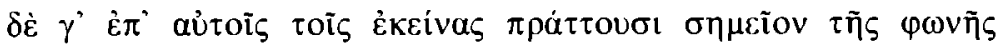

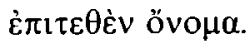

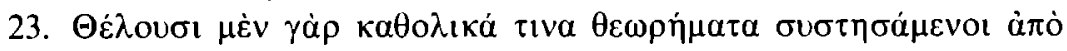

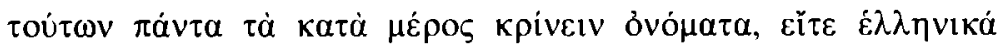

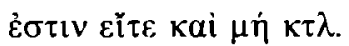

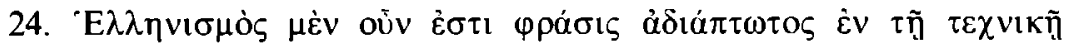

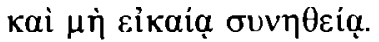

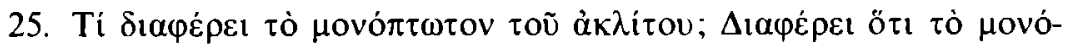

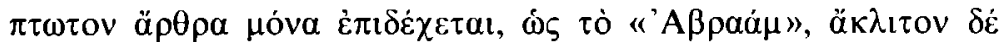

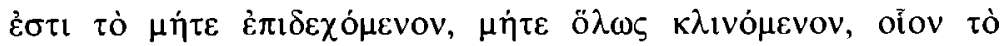
"oũ $», \tau o ̀ ~ « \delta \dot{\varepsilon} \mu \alpha \varsigma »$.

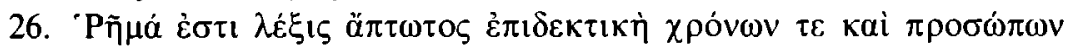

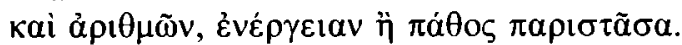

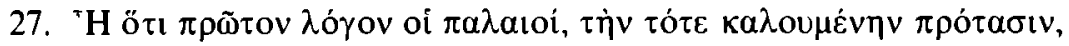

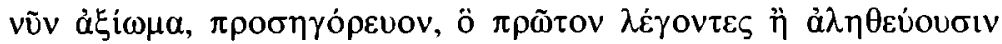

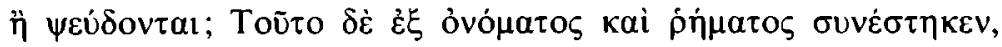

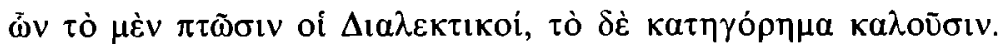

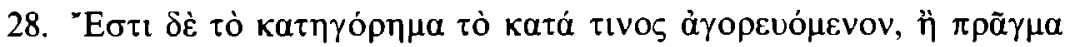

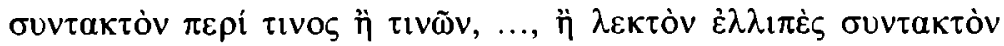

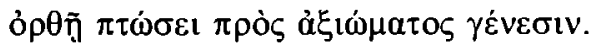

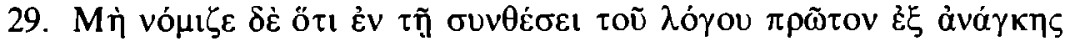

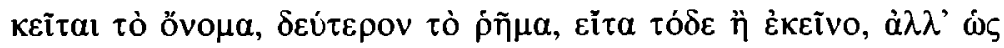

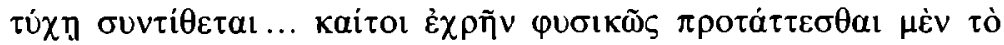

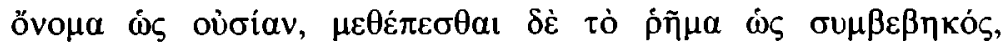

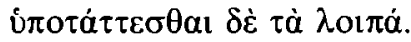

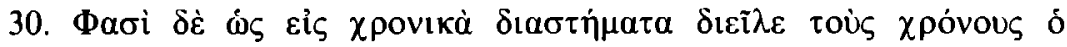

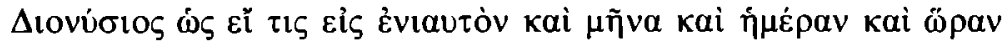

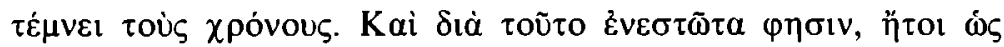

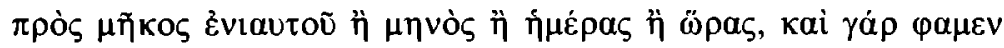

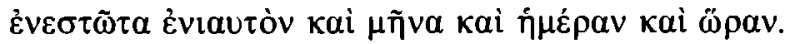

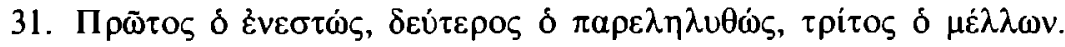

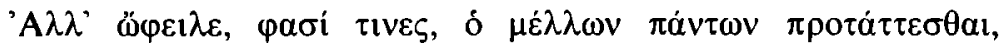

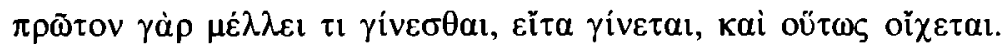

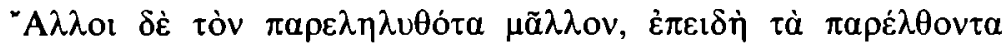

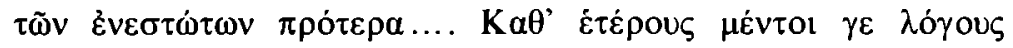

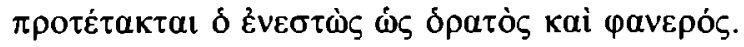

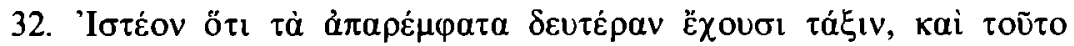

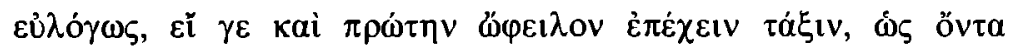




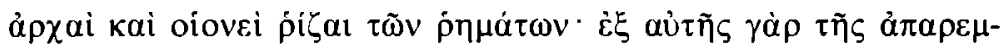

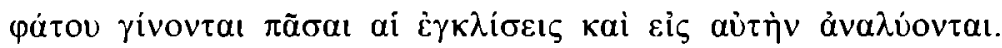

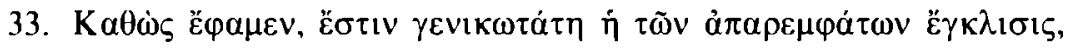

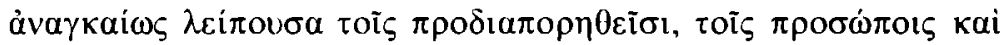

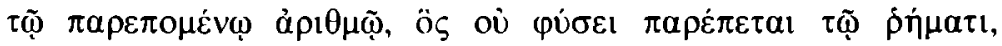

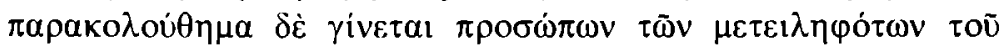

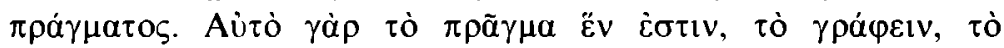

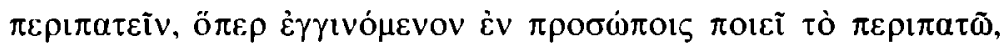

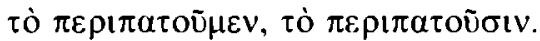

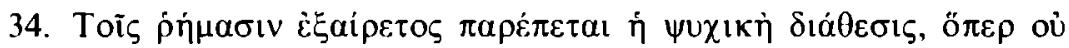

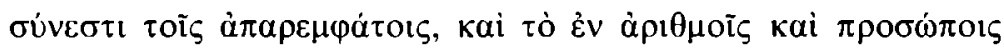

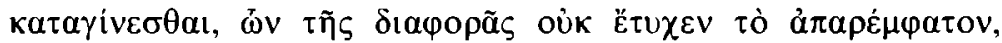

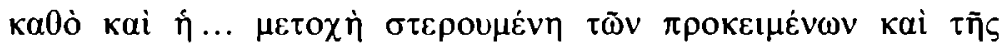
$\tau \tilde{\omega} v \dot{\rho} \eta \mu \alpha \dot{\alpha} \omega v i \delta \dot{\delta} \alpha \varsigma \dot{\alpha} \pi \varepsilon \beta \lambda \dot{\eta} \theta \eta$.

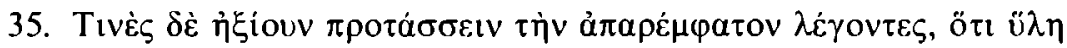

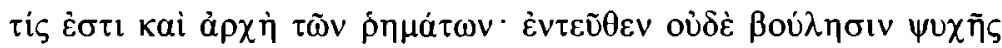

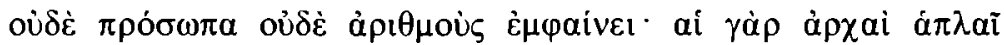

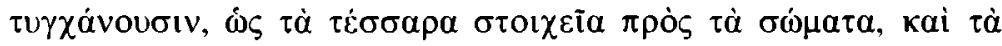

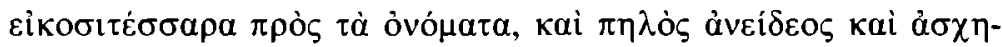

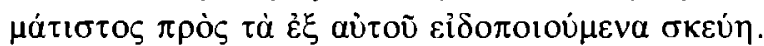

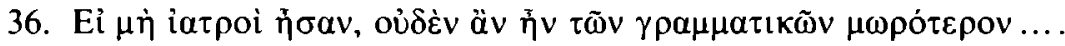

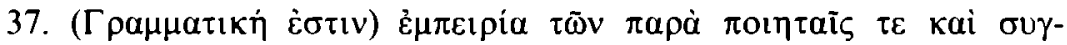

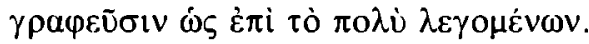

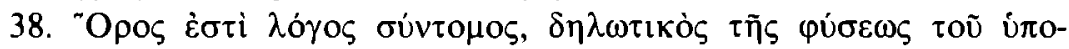

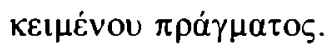

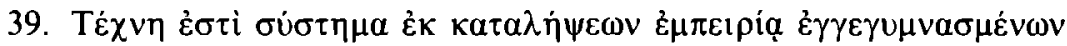

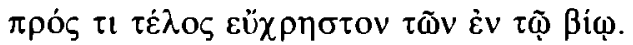

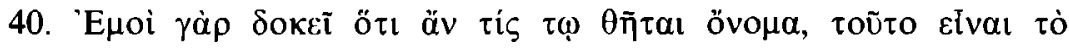

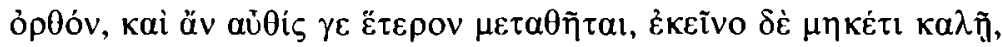

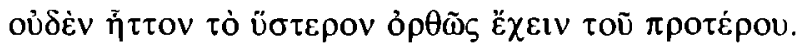

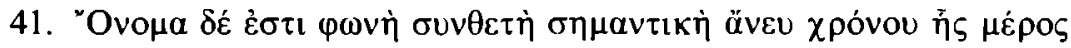

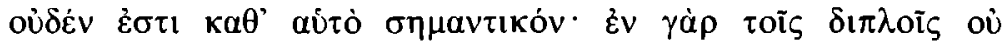

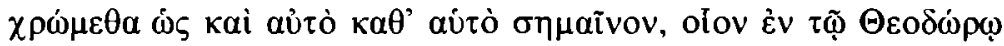

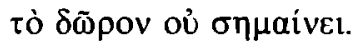

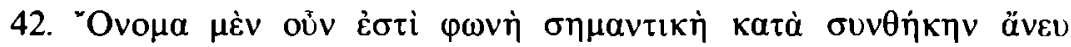

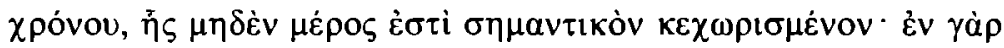

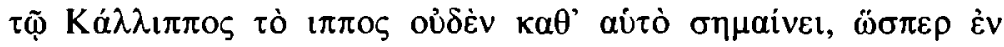

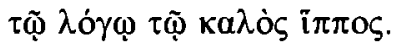

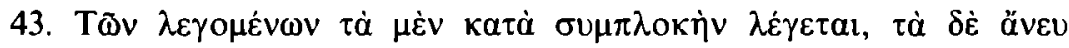

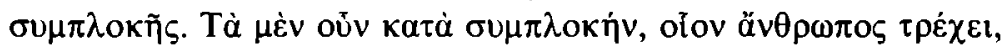




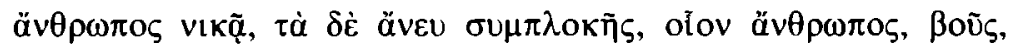
$\tau \rho \varepsilon ́ \chi \varepsilon 1, v i \kappa \tilde{a}$.

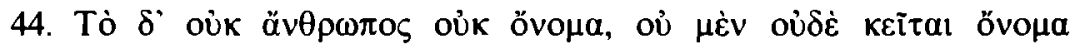

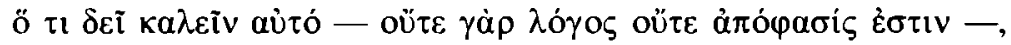

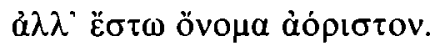

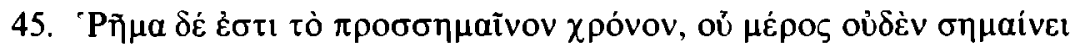

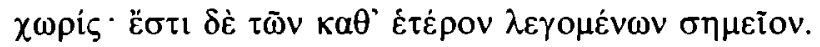

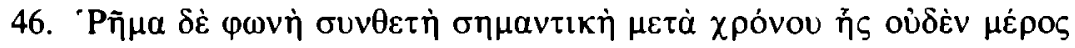

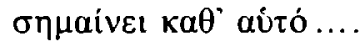

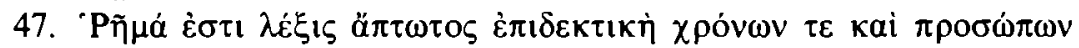

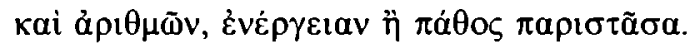

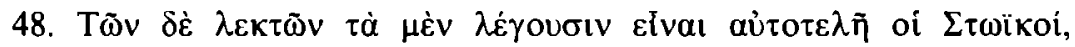

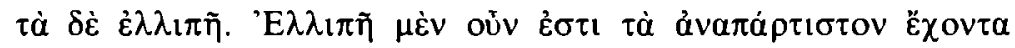

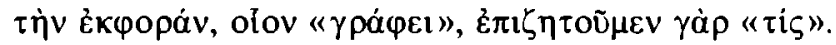

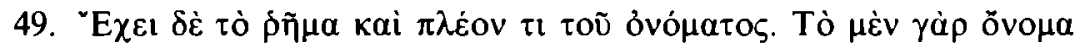

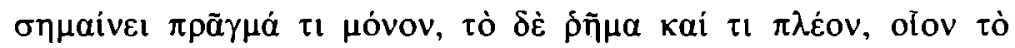

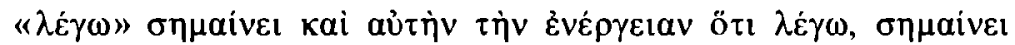

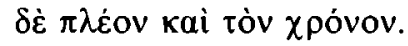

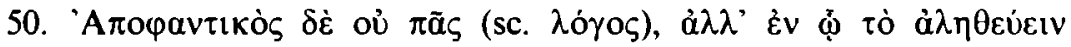

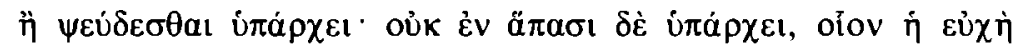

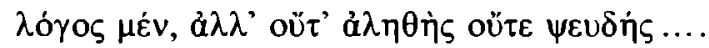

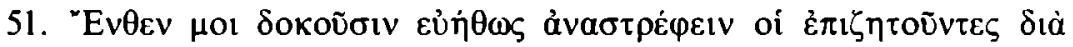

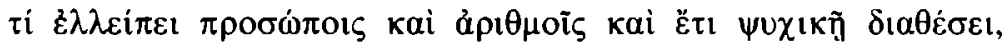

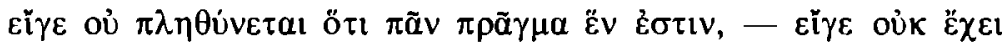

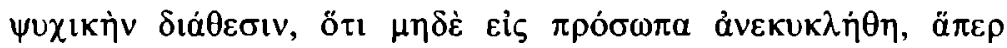

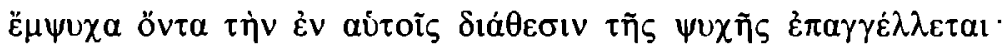

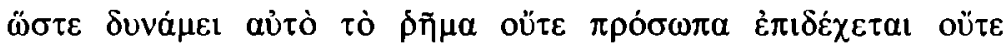

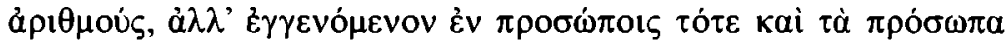

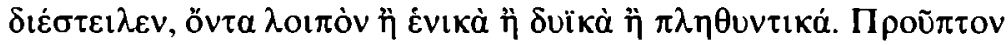

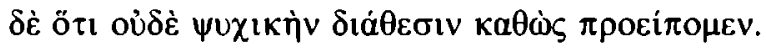

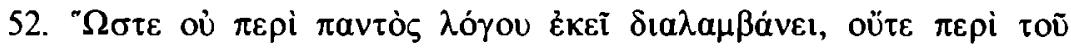

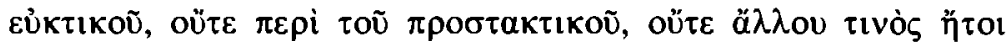

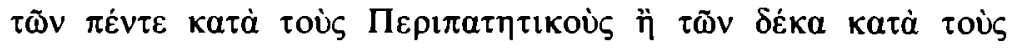

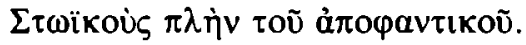

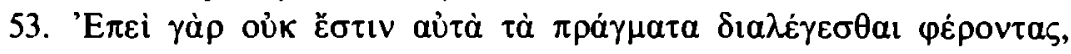

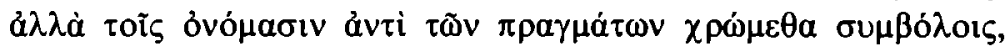

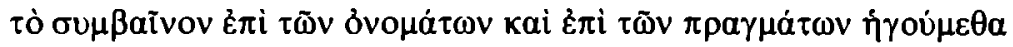

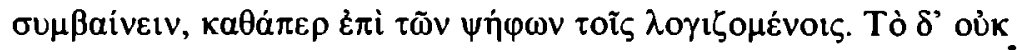

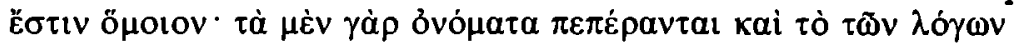




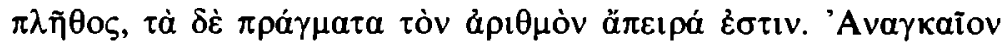

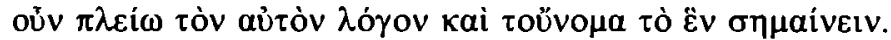

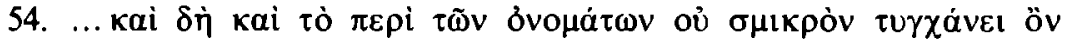
$\mu a ́ \theta \eta \mu \alpha$.

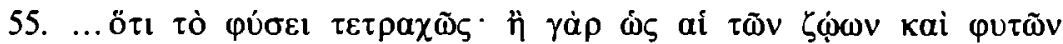

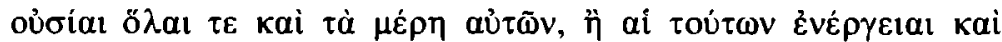

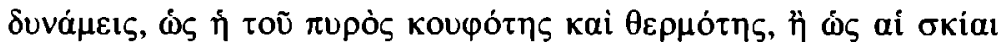

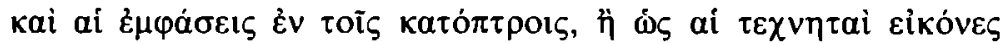

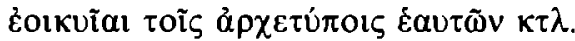

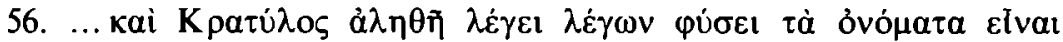

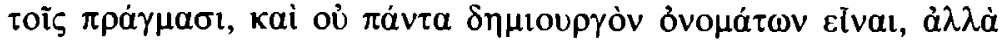

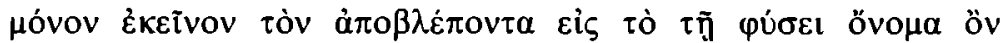

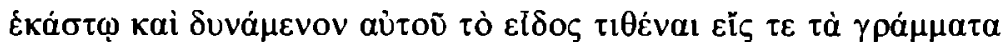

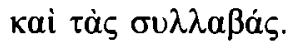

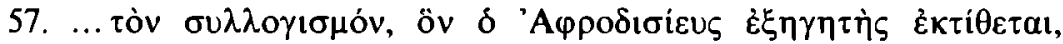

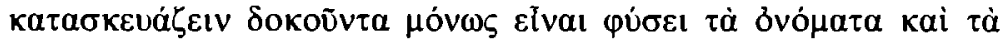

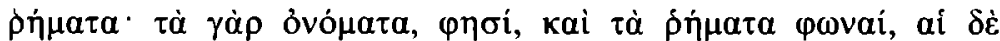

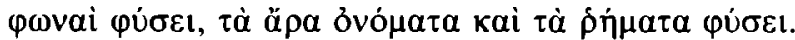

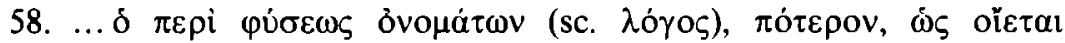

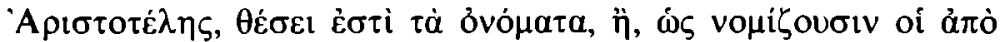

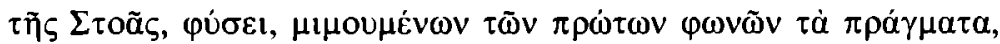

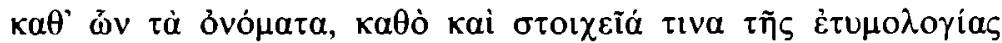

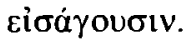

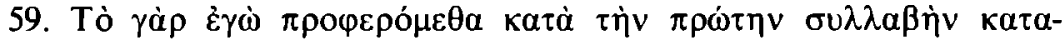

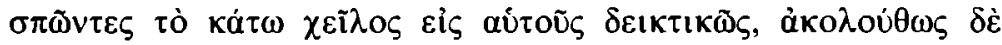

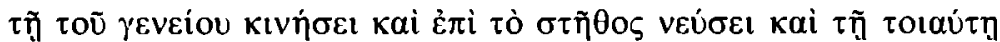

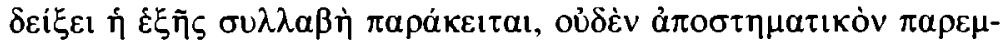

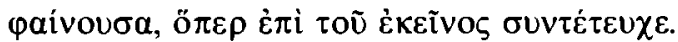

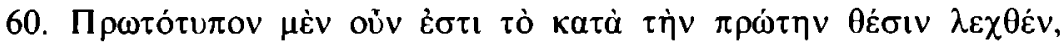

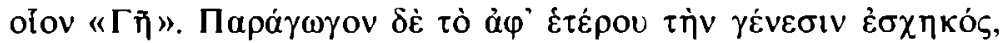
olov «Гaıñíos».

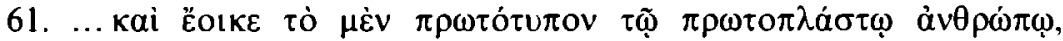

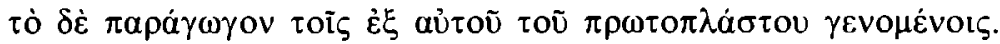

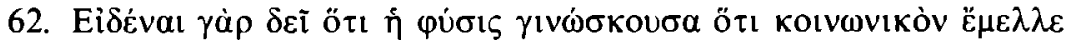

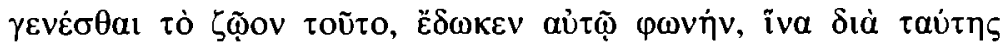

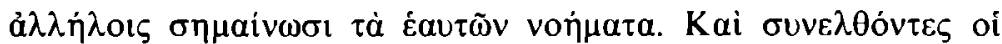
äv $\theta \rho \omega \pi \mathrm{ol} \mathrm{\sigma uv \varepsilon ́ \theta \varepsilon v \tau o} \mathrm{\pi \rho ò \varsigma} \mathrm{ả \lambda \lambda \eta ்่}$

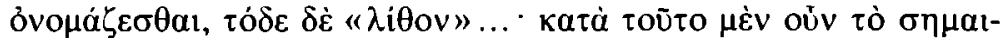

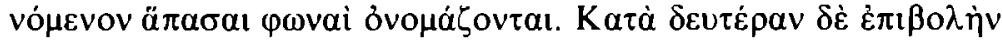

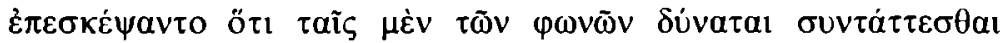




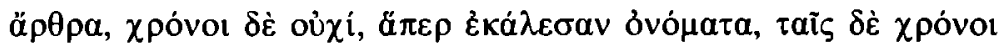

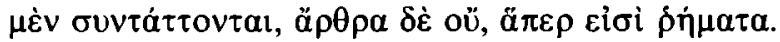

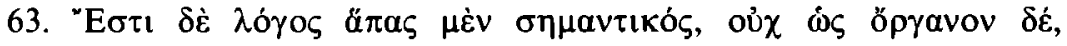

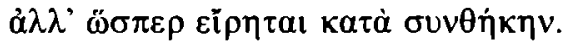

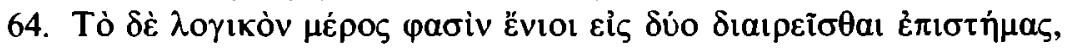

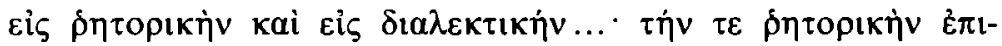

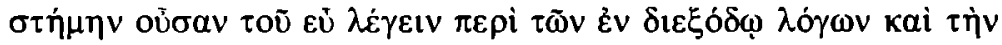

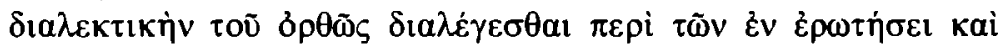

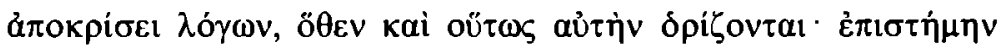

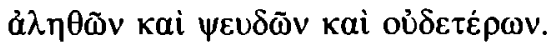

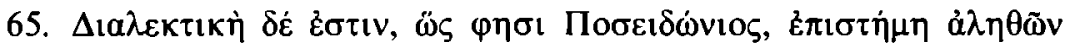

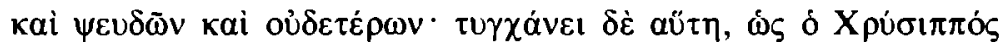

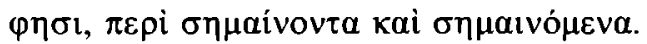

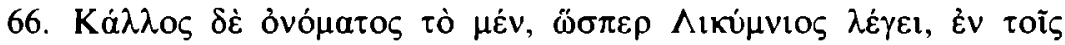

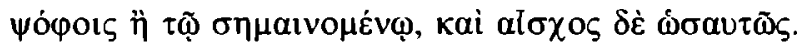

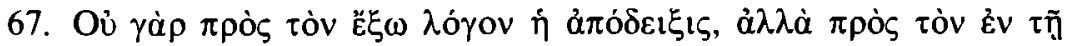

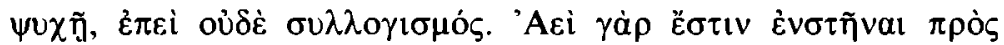

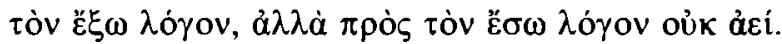

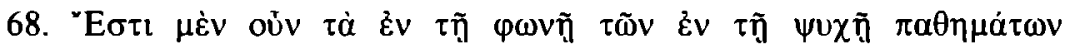

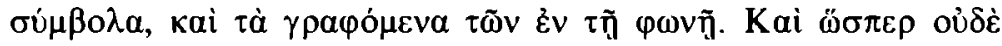

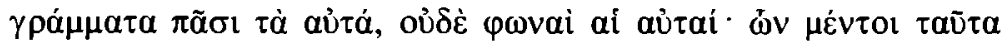

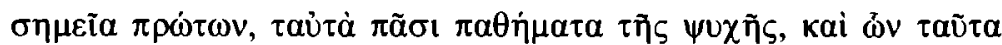

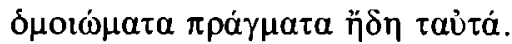

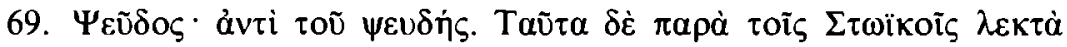

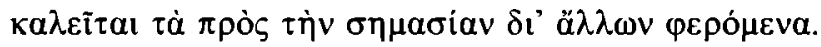

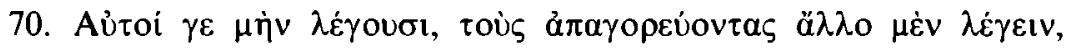

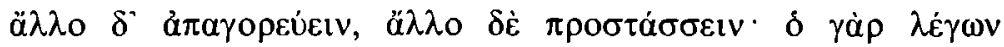

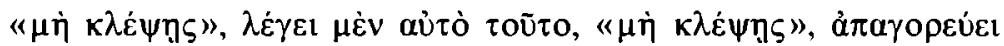
$\delta \dot{\varepsilon} \kappa \lambda \dot{\varepsilon} \pi \tau \varepsilon t v, \pi \rho \circ \sigma \tau \dot{\alpha} \sigma \sigma \varepsilon \imath \delta \dot{\varepsilon} \mu \grave{\eta} \kappa \lambda \dot{\varepsilon} \pi \tau \varepsilon \iota v$.

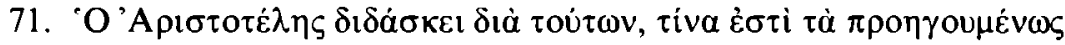

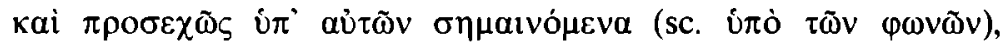

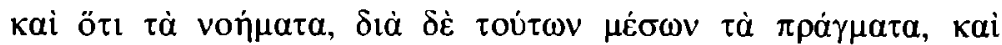

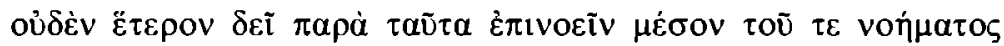

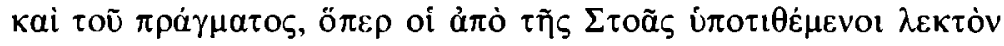

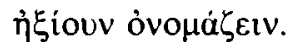

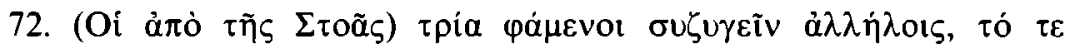

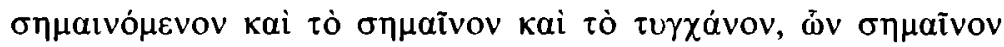

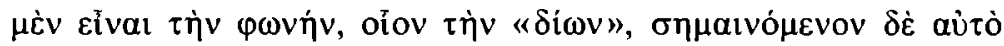

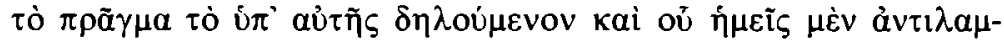

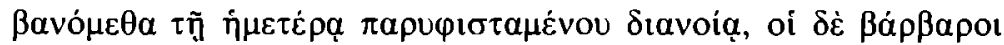




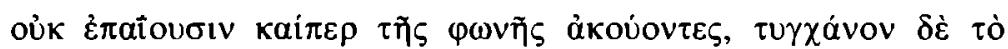

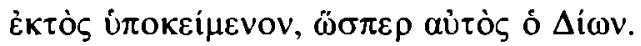

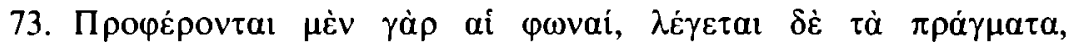
$\ddot{\alpha} \delta \grave{\eta} \kappa \alpha i ̀ ~ \lambda \varepsilon \kappa \tau \dot{\alpha} \tau u \gamma \chi \alpha \dot{\alpha} v \varepsilon \imath$.

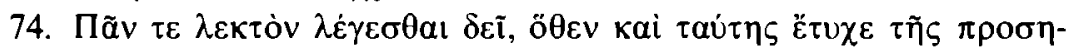
ropias.

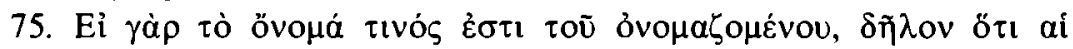

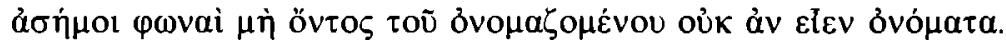

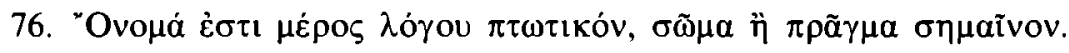




\section{INDEXES}

\section{PERSONAL NAMES}

'Abbād b. Sulaimān 28, $135^{34}, 175^{65}$

'Abd al-Gabbār $32,33,125,134^{31}, 147^{21}$, $152,153,156,157,158,159.175,187$. 188,189

'Abd al-Malık 4

'Abd al-Qāhır al-Ğurğāni 58, 59, 59 $9^{34}$, $75,131^{25}$

Abraham of Hermonthis $3^{16}$

Abū 'Alī see : al-Ğubbā'ì

Abū 'Amr b.al-'Alā' 17, 150

Abū 'l-Aswad see . ad-Du'alī

Abū 'l-Hasan al-Muhtār 118, 119

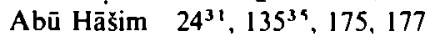

Abū 'Isā al-Munağğim $2^{7}$

Abū 'l-Tayyıb al-Lugawi $6^{29}$

Abū 'Ubaid 40

Abū 'Ubaida 159,160

Afnan, G. $10^{50}$

al-Ahfaš, al-Awsat $45,57,57^{26}, 58,59$, $61,71,149,150,153,172^{53}$

al-Ahfaš, al-Kabir 17

al-Ah̆faš, as-Sagir $17^{78}, 126^{67}$

Ahmad b Mūsā $95^{21}$

Ahmad b Yahyyā see : Ta'lab

Ainesidemos $101^{52}$

Alexandros of Aphrodisias $36^{110}, 50,53$, $161,164^{11}$

Ali b. Abì Tālib 5, 6, 45, 72

'Alī b. Sultạn al-Qārī 21 16

Ammonios 10, 31, 32, 46, 50, 12038, $146^{113}, 147,147^{118}, 163,166,170,171^{45}$, $172,174,174^{59}, 181,182^{26}, 185,189$

Antipatros $27,183^{31}$

Antusthenes $40^{13}$

Apollonios Dyskolos $23^{28}, 40,47,48^{77}$, $52,56,60,65^{71}, 70,71^{4}, 79,82,84$, $87,88,141,142,146,148,183^{33}, 185$

(Apuleius) $181^{25}$

Archedemos $77^{36}$

Aristotelikoi see : Peripatos

Aristotle VIII, 8, 10, 21, 23, 38, 39, 40, $41,41^{27}, 42,43,46,52,55,55^{11}, 56$, $61,64,65,71,74,75,75^{30}, 77,80,99$. $120,121,122^{47}, 125,126,129,130,135^{35}$, $137,138,139,139^{62}, 140,141,145,146^{11}$,
$160,161,165^{16}, 166,166^{20}, 167,171$,

$172,173,174,174^{54}, 174^{60}, 179,180^{19}$,

$182,184,185,187,188,189$

Arnaldez, R $166^{22}, 190^{70}$

al-Ašari $41,100,151,154,158,158^{\circ}$, 175

Ašarinya $100,152^{26}, 152^{27}, 157,159$, $188^{58}$

a)-Asma'ī $86^{47}, 110$

(Auctor ad Herennium) $93^{19}$

Augustınus $161,165^{17}, 166^{20}, 170,170^{45}$. 181,183

al-Azharī $158^{58}$

al-Bagdādĩ $158^{61}, 160^{\text {st }}$

Bagdādıyyūna $107,108,112,113,114$, 115

al-Baıḍ̄āī $156^{45}, 158,159$

al-Balādurī $4^{17}$

Balázs, J $47^{76}$

al-Bãqillānì $\quad 42,156,156^{48}, 157,158,176$

Barhebraeus 74

Barwıck, K. $12,26^{44}, 40,40^{12}, 42^{31}, 62^{50}$, 93

Bașriyyūna $78,83,84,85,86,107,108$, $109,110,111,112,113,114,115,124^{55}$, $126,130,131,145,175,177$

Baumstark, A 5

Benediktsson, $\mathrm{Hr} \quad 32^{77}$

Bergh, S. van den $98,131^{25}, 134^{33}$

Boethius $180^{19}$

Bonebakker, S. A $161^{73}$

Bouman, J. $152^{27}$

Bravmann, $M \quad 21,22,23,46^{68}$

Buhtî̌ū' $95^{21}$

al-Būrāni, Abū 'l-Hasan $150^{5}$

Canard, M. 119 ${ }^{3}$

Carter, M G $14,15,16,17^{77}, 18,45^{58}$, $66,112^{36}$

Celsus 91

Charisius 93, 170

Choiroboskos $56^{14}, 84^{87}, 168$

Chomsky, N vIl

Christensen, J. $55^{7}$

Chrysippos $75,76^{130}, 165,166,179$, $179^{16}, 181,181^{23}, 183^{31}$ 
Cicero $93^{19}, 167$

Coseriu, E $170^{45}, 174^{60}$

Dasber. H $37^{115}$

Danıélou, J $177^{7 \mathrm{~B}}$

Daube, D $101^{53}$

Deıchgraber, K. 91

Demokritos 100

Derbolav, J 16410

Diem, W. 45, 49, 50

ad-Dinawari 110

Diogenes of Babylon $30.37,40^{12}, 42^{31}$, $46,55,56,183$

Diogenes Laertios $146^{116}, 179^{16}$

Diokles Magnes 19

Dionysios Thrax 4, 40, 49, 52, 56, 60, $71^{4}, 76^{3 n}, 94,94^{20}, 122,130^{19}, 141,168$, 186

ad-Du’alī, Abū 'l-Aswad 5, 6, 7, 10, 11, 24

Dunlop, D M 1286

Eche, Y $117^{18}$

Egeria 3

Elias of Tirhān 24

Epikouros $164,164^{9}, 164^{12}$

Ess, J. van $129,176^{75}, 187$

Eukleıdes 125

al-Fārābi $39,41,45^{57}, 46,51,52,53$, $56,57^{21} .62,64,67,68,71,76,76^{30}$, $84,109,117,121,122,123,124,126$, $128,128^{6}, 129,138,139,139^{62}, 140,147$. $149,173,174,174^{62}, 187,188$

al-Fārısī $49,59^{34}, 116,124,150,154^{38}$, 162

al-Farrā' 67, 108, 110, 144, 149,150

Fehlıng, D 93, 17044

Fihrist see. an-Nadim

Finnegan, J $36^{110}$

Fischer, J B 23

Fleısch, H $12,107,109,110,113,149$, $173^{56}$

Flügel, $\mathrm{G} \quad \mathrm{vII}^{4}, 107$

Frank, R. M 188

Fuick, J. $6^{29}, 173^{56}$

Ğābir b Ḥayyān 18, 21, 46, 13432, 187, 188

Galenos $18^{81}, 91,94,95,95^{22}, 95^{24}, 96$, $101^{52}, 104,165^{18}$

al-Ğarmì 110

al-Ǵarnātī, Abū Hayyān 166² 1

Gatje, H. $44,52,120,121,171$

a]-Ǵazzālī $37,43,44^{51}, 56,71^{6}, 74,126$, $126^{69}, 138,139,141,155,155^{43}, 156^{47}$. $157,158^{60}, 159,171,171^{50}, 177,177^{80}$

Ğıbrìl b. Buhntīšū" $95^{21}, 96$
Goichon. A M 35, 36

Goldziher, I 103

Greene. J C vill'

Gregorios of Corinth 74, $82^{70}$

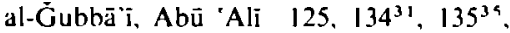
151

al-Ğurḡànì see . Ahd al-Qāhır

al-Ğuwaıni 177

Gyeke, Kw $171^{49}$

Hālıd b Yazid b Mu'āwiya $117^{18}$

al-Ȟalīl $7,10,13,17,19,24,29,90,96$, 106. $114.118^{24}, 150$

Hamza al-Isৎahāni 4

Hanafiyya 104

al-Harirī 1235s

al-Hasan. b Suwār $34,48^{79}, 64,65,120$. $120^{38}, 171.172,174$

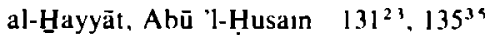

Heınrichs, W. $161^{73}, 185^{44}$

Herakleides of Tarente 91

Herodianos $22.23^{2 \mathrm{~s}}$

Hıppokrates $121^{40}$

Hıšām b Mu'āwıya 54,144

Horowitz, S. 32

Hosroes Anuširvān 2

Hubaiš 9521, $95^{22}$

Hunaın b Ishāq $10,13,20,22,36^{110}, 94$. $95,95^{21}, 95^{24}, 96,117,118,187$

al-Ĥārrızmì I, 20, 22, 39, 43, 45, 46, 51, $74,118,126,139,141$

Hymes, D VII $^{3}$

lbn al-Anbārī, Abū Bakr 85

Ibn al-Anbārī, Abū 'l-Barakāt 19, 20, 41, $43,44^{51}, 49^{82}, 53^{108}, 59^{38}, 76^{30}, 83,84^{7}$, $85,86,97,98,100,102,103,104,104^{66}$. $107,111,134^{31}, 140,149,175,176,177$

Ibn al-'Aqîl $152^{20}, 188^{5 \mathrm{H}}$

Ibn al-'Assāl 43

Ibn al-Atir 66

Ibn Fārıs $45^{58}, 54,57,58,120,176^{72}$

Ibn Ğanāḥ see ' Marwān b Ġanāh

Ibn Ğınnī $20^{9}, 21,25^{40}, 28,40,43,48^{79}$. $66,67,69,94^{20}, 97,105,108,109,123^{55}$, $133^{30}, 144^{103}, 150,151,153,154,155$, $157,159,160,169,171,173^{56}, 174,176$. $176^{73}, 177,186$

Ibn Hāğıb 66, 156

Ibn Hālawaih 49

Ibn Haldūn 1,63

Ibn al-Hayyāt 126

Ibn Hazm $88^{11 '}, 100,103,126,147,153$, $156^{48}, 172^{54}, 173^{56}, 176^{70}, 188,188^{61}$, 189,190

Ibn Hıšām $82^{73}$ 
Ibn Kaisān 40, 57, 106, 116, 125, 126. 136

Ibn Kullāb $160,160^{70}$

lbn Madā' 67, 69.70, 153

Ibn Rusid $46^{\text {th }} \cdot 138^{42} .139,189$

Ibn as-Sarrāg $57,81,81^{\circ 9}, 85,105,116$, 124. $125.140 .140^{70}$

Ibn as-Sikkit 136

Ibn Sinā 21. 22, 32, 36. 41, 46 $66^{66}, 52,80$. 126. $139^{95}, 147,171,189$

Ibn S̈uqair 126

al-Iği 174" I

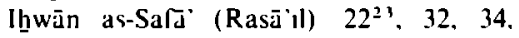
$46^{\text {ts }}, 147$

Isã b Umar 17,109,150

'İsa b Yahyd 9521

al-Isfarāinin 177

Ishāq b Hunaın 23, 35 $35^{9}, 139$

Ismāīl al-Warrāa $18^{78}$

Jacob of Edessal $3^{14}, 4,9,62,118,146^{114}$, $173^{57}$

Jahn, $G \quad 43,44,44^{49}$

Jamblichos 37

Joseph of Ahwāz 4

Johannes bar Zu'bı 147

Johanne, Damaskenos $10^{50}, 137^{45}$

Johannes Glykas $39^{\prime 0}$

Johannes Phıloponos 56, 56 ${ }^{14}, 121,121^{40}$, $128^{\circ}$

Justınuanus 2

al-Kındi $53,123^{52}, 124,153^{28}$

al-Kısā'ì 108, 109, 110, 144

Koerner, E. F. K VII ${ }^{3}$

Koller, $\mathrm{H} \quad 145$

Konstantinos VII Porphyrogentos $119^{31}$

Kopr, L. $162^{4}$

Kratylos $163,164^{9}, 164^{10}$

Kraus, $P 18$

Küfiyyūna $78,83,84,85,86,107,108$, $109,110,111,112,113,114,115,124^{55}$, $126,130,131,136,176,177$

Kunjunnı Raja, K 15796

Kyrillos 119

Leon Philosophos $120^{33}$

Likumnios $179^{17}$

Long, A A $55^{10}, 182^{26}$

Loucel, $H .162^{3}, 162^{4}, 162^{5}, 173^{56}$

Lucretius 164

Madkour, I. 7

al-Mahdi $110,117^{1 \mathrm{~B}}, 120$

Mahzūmi, M 112

al-Ma'mūn $117,117^{18}, 120^{33}, 150^{5}$

al-Manșūr $10,95,117^{18}, 120$
Margoliouth. D S. $101^{54}$

Marwān b. Gaanāh 25.80.81

al-Mas'ūdì 95.110.117

Matlā b Yũnus $46^{60}, 52.64 .122 .125$. $138,139,141^{78} \cdot 160^{70}$

al-Māzınì $10,20,43,106.109,114,150$, 159

Menodotos 9521

Merx. A 8, 9. 38, 41, 43, 44, 45, 61, 62, $67.68,77,77^{40}$

Metle, H J $181^{23}$

Meyerhof, M 117.118

Mohrmann. Chr vill

Muammar 188, 189,190

Mu'āwiya $117^{1 \mathrm{~B}}$

Mubārak, M IX, $5^{25}, 17^{78}, 113$

al-Mubarrad $10,40,43,44^{51}, 53^{110}, 54$. $59^{35}, 73^{17}, 107,108,110,111,114,124$, $126^{67}, 129^{12}, 130^{15}, 150,159^{66}, 175,177$ al-Mufaddal, ad-Dabbi 112

Muḡāhıd b Ǵabr $135^{30}$

al-Muhntār see Abū "l-Hasan

al-Muqtadir $117^{20}$

al-Mu'tadid $117^{20}, 118$

al-Mulawakkıl $117^{20}$

Mutazila IX, 13, 58, 100, 125, 128, 129.

$131,135^{35}, 137^{4 \mathrm{~h}}, 149,150,151,152$.

153, 154, 155, 156, 157, 158, 159, 160,

$161,162,175,176,177,188,189$

an-Nadim (Fihrist) $126^{67}, 154^{3 \mathrm{~A}}$

Nağğar, M 'A 82

an-Naẓzām $32.60^{43}, 126,137^{46}$

Noldeke, Th. 6

Nyberg, H S $149^{2}$

Origenes $165^{16}$

Paulus of Nisibis $78^{41}$

Paulus Persa $77^{41}$

Perıpatos (Arıstotelıkoı) 32. 50,67, 147

Philınos of Kos 91

Phıloponos see: Johannes Philoponos

Photios 119, $119^{24}$

Pinborg, J $164^{14}, 167,171^{50}, 180^{19}, 182$

Placita Philosophorum 32, 37, 61, 72'0, 105, 178

Plato $18^{81}, 27,40,61,134^{12}, 163,164^{11}$, 173. $179^{14} .187$

Plotinos 161

Ploutarchos $72,76^{15}, 77^{36}, 181$

Pohlenz, M 55, $179^{18}, 181^{24}$

Porphyrios $10,128,170^{43}, 180^{18}$

Poseidonios $37^{113}, 156^{45}, 179^{16}$

Pretzl, O. $158^{61}, 160^{69}$

Priscianus $48^{77}, 56,76,77^{37}, 168$ 
Proklos $134^{32}, 161^{72}, 163,163^{4}$

Protagoras 145

Pscllos 118

Ptolemaios 95, 125

Publıus Nigıdius $165^{1 \mathrm{~A}}$

Quintilianus $27^{48}, 93,168$

Qustā b. Lūqā $37.72^{10}, 105.117$

Quirub 106, 150

al-Quwarīi $117^{20}$

Rasāill see: Ihwān as-Sạā'

ar-Rašid, Hārūn $117^{1 \mathrm{~B}}$

ar-Rāzì, Faḥr ad-Dìn $22^{23}, 34,37,43,58$, $64,74,135^{36}, 136^{39}, 141,141^{82}, 143,144$, $159,159^{62}, 171.190^{71}$

ar-Rāzī, Muh b Zakarıyyā 122, 123

Rescher, N $134^{33}, 135^{35}$

Rcuschel, W 7.17

Romanos 56

ar-Ru'āsi $110^{28}$

ar-Rummāni $86,94^{20}, 113,116,124,125$, 150

Sacy, A I S de $43,44^{49}, 45$

as-Safadi $161^{73}$

aš-Šāfíi 16, $160,101,120$

aš-Šahrastāni $156,158^{\circ 1}$

Šāpūr $2^{7}$

as-Sarahsī $123^{52}$

aš-Šātibī 23

Schacht, J 16,98, 101, 103

Schmidt, R $183^{32}, 184^{38}$

Schneider, R. $48^{7 \text { ? }}$

Scholia Dionysios Thrax 22 ${ }^{2}, 23,27,31$. $33,47,56,60,64,76^{36}, 77,82,105,128$. $142,170^{43}, 189^{67}$

Seneca $135^{39}$

Sergıos of Rešainā 4

Sextus Empıricus $46,62,91,130^{20}, 132$, $146^{116}, 181,182,184^{37}, 185$

Sezgin, F. 16, 17

Sibawaıhi $7,10,11,13,14,15,16,17$, $19,23,29,38,39,40,41,42,43,44$, $44^{53}, 45,46,47,49,50,51,53,57,64,71$. $74,74^{22}, 77,77^{40}, 78,79,80,82,83,84$, $86,90,96,101,109,112^{36}, 114,121,141$, $149,150,159,184$

as-Siğistāni $75^{25}, 76^{30}, 123,124$

Simplikios $2,121^{38}, 181^{23}, 187^{52}$

as-Sīrāīi $6^{29}, 21,43,45^{61}, 57^{26}, 77^{38}$, $79^{52}, 81,116,122,123,124,125,126$, $140,150,151,160^{70}$

Skeptıko1 91, $92^{10}$

Sokrates $29,174^{59}$

Sophistai 166, 167
Sophronios 81,82

Speck, P $119^{31}$

Spitaler, A $6^{29}$

Steinthal, H. $49^{82}, 60^{41}, 133^{31}, 138^{52}$. $163,180,180^{19} \cdot 180^{20}, 183.184$

Stephanos 68

Stoa(Stolkol) 9, 26, 27, 2964, 30, 32, 33, $37,42^{31}, 49,53,54,55,56,60,62,65$, $68,71,72,74,92^{7}, 94^{20}, 98^{44}, 123,126$, $127,129,130,133^{31}, 134,135^{35}, 146$, 147. $156^{45}, 157^{56}, 164,165,166,167$, $168,169,177,178,179,180,181,182$, $183,184,185,186,187,188,189,190$

Sūsıānos (?) $121,121^{40}$

as-Suyūti $x, 28,81,135^{36}, 149,150^{5}, 166$, $166^{19}, 174$

Tābıt b. Qurra $10^{50}, 117$

Ta'lab $19,20,51^{46}, 67,107,108,109,110$, $126^{67}, 154^{38}, 176^{71}, 177$

Tarazi, F H 79

at-Tauhìì 122, 123, 124

Theodas of Laodike1a 91

Theodosios 42, 63, 118,119

(Theodosios) $145,145^{106}$

Troupeau, G 116

Tryphon $27,28,48,48^{77}, 50,53$

'Ubaidi, R A. $66^{76}$

Uhlig, G. $42^{32}$

al-"Ukbarī $59,140^{70}, 176^{72}$

'Umar b 'Abd al-'Aziz $117^{20}$

Vasśesska $157^{56}$

Varro $26,27,62^{49}, 93^{13}, 168,169^{37}$, $169^{41}, 170^{44}, 181^{23}$

Wakj $4^{18}$

Walzer, $R \quad 95,121^{38}$

al-Wātıq 95

Wehr, H. $6^{29}$

We1l, G $18,25,26^{45}, 29^{65}, 53,107,109$. 112,176

Weiss, B $174^{61}$

Weiß, J $12,38,39,44,45,47$

Wild, S. 5

Yahyā b. 'Adī $105,120^{38}, 123^{52}$

Yahyyā b. al-Bitrīq 10,95 -

Yāqūt 112

al-Yazidi 110

Yühannā b Hailān $117^{20}$

Yūḥannā b Māsawaih 96,102

Yūhanaña an-nahwi see : Johannes Philoponos

Yūnus b. Habrīb 17, 109

az-Zağgăā $\quad 85,110,140$

az-Zağğāğì IX, $11,17^{78}, 19,23,39^{10}, 40$, 
$41,43,44,45,46,48^{79}, 53^{108}, 54,57$, $58,59,60,61,69,74,75^{24}, 77,77^{38}$, $78^{43}, 78^{47}, 79,80^{54}, 81,83,85,88^{109}$, $97,104^{63}, 104^{66}, 106,108,109,110,115$, $116,117,124,125,126,128,129,130$, $131,132,135^{36}, 136,137,138,139,140$, $141,143,144^{101}, 146,147,150,151^{23}$, $152,153,154,155^{43}, 160,161,172^{53}$, 178
Z̄āhiryya $103,104^{63}, 153,166^{22}, 190$

az-Zamahšañ $43,47,53,74,141$

Zenon $37^{112}, 130^{17}$

Zimmermann, F. W. 68, $73^{15}$

Zirın, R. $31^{77}$

Zlinszky, J. 10361

az-Zubaidi $173^{36}$

\section{ARABIC TERMS}

\begin{tabular}{|c|c|}
\hline$\underline{t} r$ & $\bar{a} t \bar{a} a r \quad 188$ \\
\hline hod : & $m a^{\prime} h u \bar{d} d \quad 41,84$ \\
\hline$d w$ & adā $38^{3}$ \\
\hline gas & ustuquss 46 \\
\hline r. & asl $85,88,166,169$ \\
\hline & $\begin{array}{l}\text { usül(an-nahw) } 12,16,18,90, \\
94,97,101\end{array}$ \\
\hline ' $f f:$ & $\begin{array}{l}\text { allf } x^{13}, 19,20,21,22 \\
\text { ally-lam } 73\end{array}$ \\
\hline$m r$. & amr 67,147 \\
\hline$n$ : & inna $53,124^{58}$ \\
\hline$s \cdot$ & insān $\quad 41,57,178$ \\
\hline$h l:$ & ahl an-nazar $72^{11}, 85,115^{5}, 131$ \\
\hline$w l:$ & awwal $53^{111}$ \\
\hline & - al-wad 29 \\
\hline$n:$ & aina $58,61,75$ \\
\hline$d:$ & Ihfidà' $73^{17}$ \\
\hline & $\underset{74^{22}}{\operatorname{mubtada}} 53^{111}, 71,72,73,74$ \\
\hline & taqrib 'alō 'l-mubtada' 59 \\
\hline$d^{\prime \prime}:$ & ihdā' $\quad 153^{28}$ \\
\hline bdl & $\begin{array}{l}\text { hadal } 16 \\
\text { abdäl al-harakã } 19\end{array}$ \\
\hline & abdäl al-asmā' 51 \\
\hline$b s t$ & zamän basi! $\quad 76^{30}$ \\
\hline ben : & quwwa hätina 189 \\
\hline$b \ln t r:$ & balan!ūr $34,121^{38}$ \\
\hline$b n y \cdot$ & $\begin{array}{ll}\text { binā } & 15^{69}, 23^{28} \\
\text { binya } & 190^{70}\end{array}$ \\
\hline byd. & bayād 57 \\
\hline byn. & bayān 63 \\
\hline $\mathrm{imm}$ & lämm 69 \\
\hline & qaul tämm 34 \\
\hline $\operatorname{lng}$ & istınnā' $104^{63}$ \\
\hline gdl & illa ğadalıyya \\
\hline$\check{g} r$ & garr 6 \\
\hline & mağrūr 68 \\
\hline$\check{g} r h$. & $\begin{array}{l}\text { lağriha } 96,97 \\
\text { mağrā (mağāri) } \quad 19\end{array}$ \\
\hline
\end{tabular}

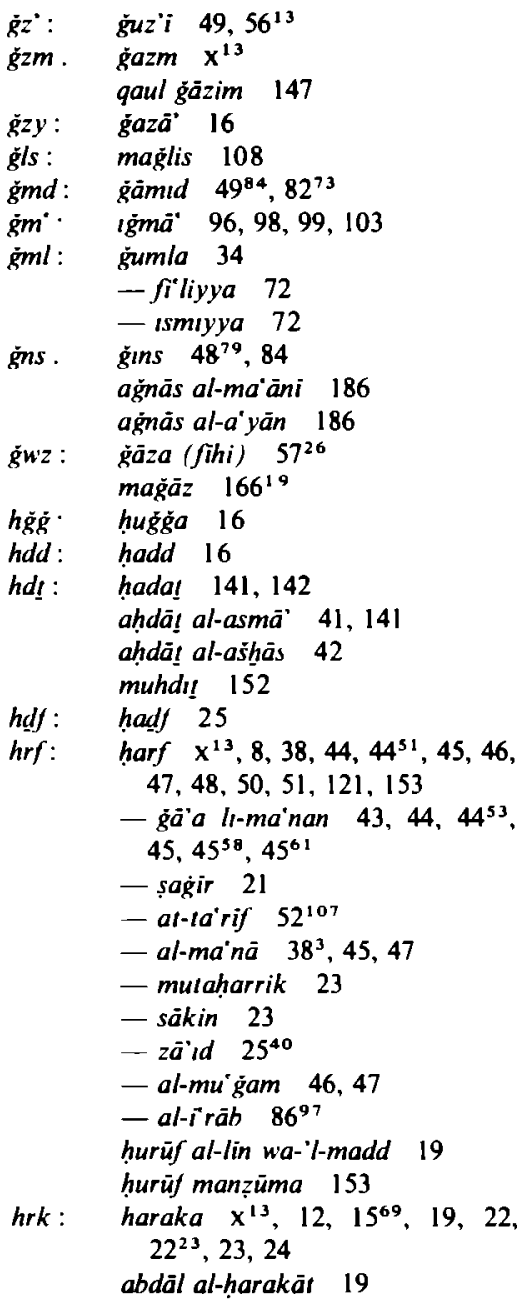


musaharrik 23, 24, $24^{31}$

harf mutaharrik 23

hss. hiss 96

hsn: hasuna $57^{26}, 71$

hasan 14

hšw: hašw 53, 53111

hāš̀ya (hawāši) 51,53

hsl. muhassal 139

Ism ġair muhasssal $139^{62}$

hdr. $\quad h \bar{a} d i r \quad 80$

hkm. hukm 7422

mahkūm $74^{22}$

hml: mahmül 74, 7422

$h w /$ häil $11^{53}, 39,39^{10}, 40$

$h w l: \quad h a ̈ l$ 8, 9, 64 $59,74,80,134^{33}$, 145

ısıshāb al-häl 98, 102, 103, 104

hyy: hayawān 57

hbr : habar $71,72,73,74^{22}, 147$

uhbär 133, 161

an al-fil 74

muhbar $71,73,145$

anhu 72, 7422

istihbār $147^{119}$

hdm. lladm 28

hlf: Imläf $66^{76}$

haviälı 51

$d w^{\prime}: \quad d u^{\prime} \bar{a}^{\prime} \quad 147$

dII : dalil 97,103

al-ısm dalil al-ma'nā $155^{43}$

daläla 158, 188

al-ıstidläl bl-'adam ad-dalil 104

madlül $155^{43}$

du'm fil dä'im 79

dhn: luwardihntyya $135^{36}, 157$

dw: $\quad$ dàt 13

- aš-šay" 158, 159

dw'q douq al-arab 11

rht ' räbı! 46, 51, 52, 53

rihä! $38^{3}, 39,45,46,52$

rtb. rutba $142^{\mathrm{HG}}$

martaha $142^{86}$

$r \dot{g} /: \quad$ ragisul []$^{53}, 39,40,42,54,57$, 178

rsm: rasm 129

rf $\quad$ raf $x^{13}, 6,15^{69}, 67,68$

mar/ü 68

rwd. murād 190

rrādi 97

zmn zamān $75^{25}, 141$

- murlaq $76^{30}, 85$

basit $76^{30}$

- miaryan $76^{30} .85$

znbr: mas'ala zunbūrtyya $109^{12}$ zyd: $\quad$ hurūf zāida $25^{40}$

ziyäda 25

zatd $41^{21}, 54,56,58,73^{17}, 85$,

$105,114^{3}, 123^{55}, 133,154,158$

s\%: $\quad$ mas'ala Intilafiyya 107

- zunbūriyya $109^{12}$

shb. sabah $99^{47}$

str. Istatara $144^{99}$

skn. harf sāktm 23

smw: sumuww 175

smy: $\quad$ ism $x^{13}, 8,11,15^{69}, 38,39$, $44^{53}, 46,48,48^{79}, 49,49^{84}, 50$, $54,133,134,136,144,150^{19}$, $153,154,155,158,175,176$, 185

$-a l-f i l \quad 83,84,133,136,155^{40}$

- li-fil $133,133^{30}$

- muhassal 139

- gair muhassal $139^{62}$

- ain 186

- ma'nā 186

al-ısm huw'a '/-musammā 134, $154,155,156,157,158,159$, 160,161

ism mudmar 51

- mubham 51

- al-išăra 51

- mausūl 52

al-ısm an-nä'ıb an al-musam$m \bar{a} 145$

al-ism dalil al-mainā $155^{43}$

iähıh al-ısm 41, 4229, 154

ahdāl al-asmāं 51

ahdā! al-asmā' 41, 141

ismiy'a 133

tasmila 155, 156, 15648, 157, $158,159,160$

musammā $x^{13}, 15^{69}, 42^{29}, 44^{53}$, $133,134,136,150^{19}, 154,155$. $155^{40}, 155^{43}, 157,158,185$

al-musammayāt tahıa '/-asmā' $176^{70}$

sunna 96,97

Isnād $72^{\mathrm{B}}$

musnad $71,72^{\mathrm{B}}, 73$

snd sanāal 57

sw' saufa 78,79

šb': $\quad$ šha $\bar{a}^{\circ} \quad 20$

şbh: $\quad q u \bar{a} s a \dot{s}-s \grave{s} b h \quad 100$

shls

ahdū! al-ašlı̄às 42

sold. sâdd 103

quyàs 'alā 'š-s̄ädd 112

šrt. šrt 14, 16 


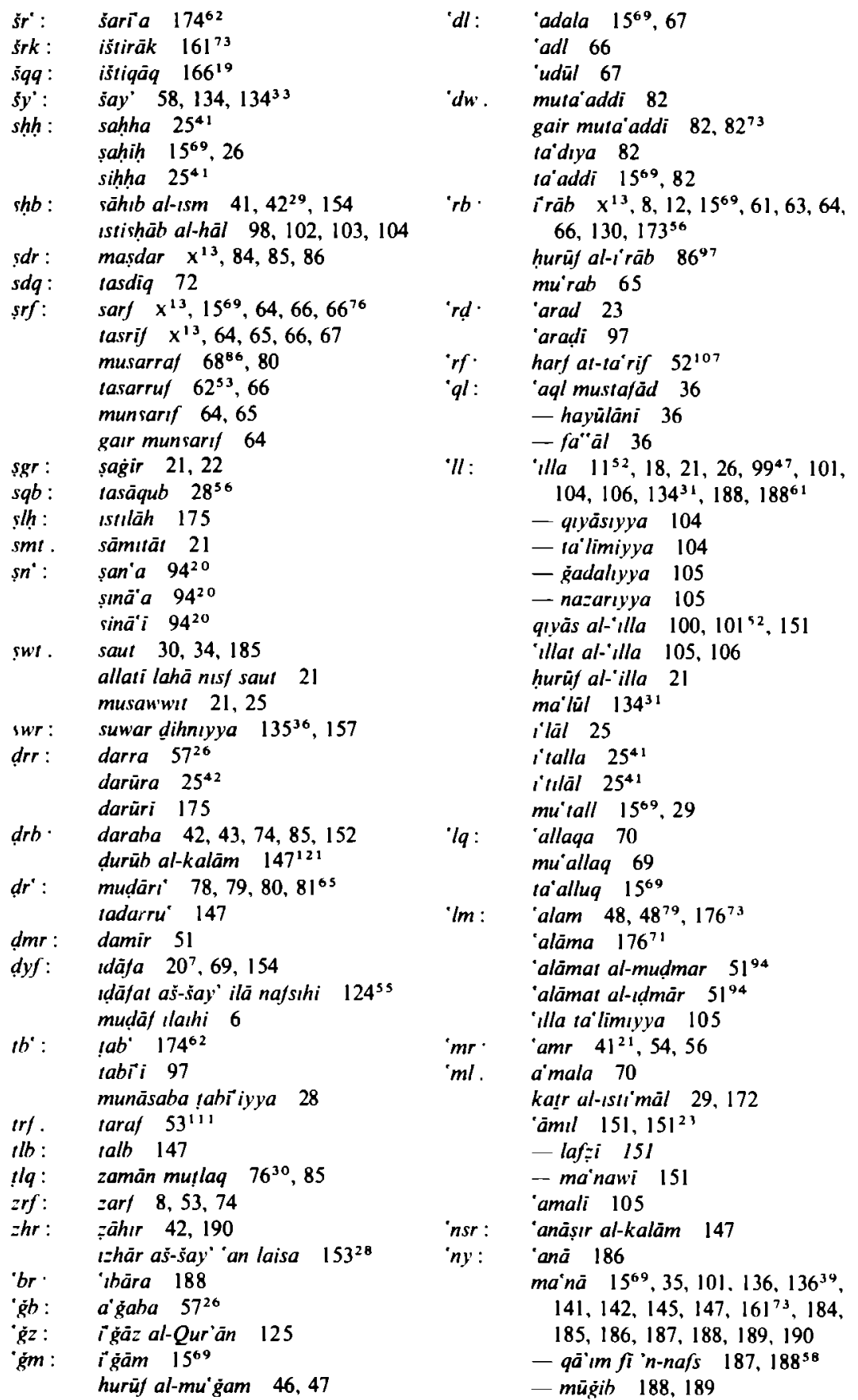


ma'äni muhtolıfo 78

al-ma'äni allati ta'tawiru 'l-asmā' 145

harf al-mainā $38^{3}, 45,47$

ısm ma'nā 186

ağnās al-mäāni 186

harf $\dot{\mathrm{g}} \bar{a}$ a li-ma'nan $43,44,44^{53}$, $45,45^{58}, 45^{61}$

ma'niyya $190^{71}$

ma'nawi $94^{20}$

'àmıl ma'nawi 151

muannā 190

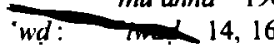

yn: ism ain 186

ağnās al-äyān 186

zamān muiayyan $76^{30}, 85$

grmtq. jarmātíqi 1

flh: Jatha $6^{28}$

frd. mufrad 139

frs faras $11^{53}, 39,40,41,42,54$, 57,178

$f r^{\circ} . \quad \operatorname{far}^{\circ} 166,169$

fsl: $\quad$ fäṣtla 46, 52

$f^{\circ}$ : $\quad$ fa ala 42,152

fil $\mathrm{x}^{13}, 8,11,15^{69}, 38,46,48$, $50,72,72^{10}, 74,153$

- däim 79

ism al-fil $\quad 83,84,155^{40}$

thbär an al-fitl 74

al-kaläm fíl al-murakallım 152, 153,154

fáil $6,18^{78}, 59,59^{38}, 72,72^{10}$

mafūl $6,59,59^{38}, 72^{10}$

"aql fa" äl 36

fkr: $\quad$ quwwa mulafakkıra 189

$f_{s f}$. falästfat an-nahn'tyyina 149

fhm. Istıfhàm 147

fyd. fäıda $15^{69}, 35,36,36^{105}, 37$, $39^{9}, 130$

afäda $35,37,45^{58}$

ifäda 35,36

mufid $15^{69}, 32^{84}, 33,34,36,37$, 144

tstajäda 35,36

mustafid 36

mustafād $36,36^{110}, 37$

aql mustafäd 36

qbh. qabih 14

$q b l \cdot$ mustaqbal $80,80^{54}$

qrb: $\quad$ taqrib 'alä 'l-mubtada' 59

qrn. iqrirān 140

gsm: aqsām al-kalām 38, 147'121

gsd: maqsūd 190 qsr : $\quad$ qāṣstr $82^{73}$

mamdūda wa-maqșūra 21

qdm: $\quad$ gadm 28

qdy: qadiya $72^{14}$

munqadi $80^{54}$

qll : $\quad$ mustaqill fi nafsiht $34^{94}$

qlb : qalb 25

gln: qälün 6

qnn : qänün 62

$q w l: \quad q a ̈ l a \quad 42^{31}$

qaul $15^{69}, 34,36$

- ğāzim 147

- tāmm 34

- nāqrs 34

qwm: mänä qä'imfín-nafs $187,188^{58}$ ıstiqāma 64

mustaqim $16^{70}, 64,65,68,80^{58}$

qwy: $\quad$ quwwa bāına 189

- murafakkira 189

qyd: muqayyad $32^{84}$

qys. quyās $8,14,16,18,90,96,98$, $101,103,104,106,111,151$, 177

- al-illa $100,101^{52}, 151$

- aššsıb 100,10152

- analogismós 101

- eptlogismós 101

— alā 'ššād 112

illa quyàsiyya 104

ktb: kataba 42

kır : ka!r al-istimäl 29

$k d b: \quad r a k d i b \quad 72$

ksb: kasb $100^{49}$

kll: $\quad$ kulli $49,56^{13}$

$\mathrm{klm}$. kalıma $38^{3}, 39,39^{9}, 46,47,67$, $141^{79}$

- qä̀ma 80

kalim $39^{9}$

kaläm 1569, 34, 36, 399, 188

anāsır al-kalām 147

aqsām al-kalām 38, 147'21

mutakallim 152

$\mathrm{kml} . \quad k a m a ̄ l ~ 24^{2 \mathrm{~B}}$

$k y f \cdot k a i f a \quad 58,61$

l. $\quad$ la- 78,79

lhq: lawāhı $62^{53}$

lgw : luga $94^{20}$

wad' al-luga $174^{61}$

ilgāं $53^{111}$

$l f z \quad l a f z \quad 35,136^{39}, 158,161^{73}, 176$, $185,187,190^{70}$

'ämil lafzi 151

lqb. laqab $48^{79}, 49^{84}$ 
lyn. hurūf al-lin 19

min - maia 75

mdd: hurūj al-madd 19

madda 22

mamdūda n'a-maqșūra 21,22

md: $\quad$ mundu 45

mdy: mādi $15^{69}, 78,80$

$m n^{\circ}:$ imimäa $54^{5}, 70^{1}$

$m y l: \quad m \bar{a}^{\prime}{ }^{\prime} l \quad 64,65,68$

nhu. nahw 1.1777

falāsıjal an-nahwlyyina 149

ndr: nawāder 11

ndw: niā' 147

$n z l: \quad$ manzila $20^{7}, 142^{86}$

nsh. munāsaba țabīiyya 28

nsb: nash 6

mansüb 69

$n$ st : allati lahā nışf șaut 25

$n ! q$. manilq at-lair $33^{87}$

mantıquyüna 139

nzr: $\quad$ ahl an-nazar $72^{11}, 85,115^{5}, 131$

nazari 105

illa nazariyya 105

muniazar $80^{\circ 4}$

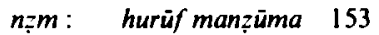

n't: na't 147

nf: $\quad$ nafa'a $57^{26}$

nfs: $\quad$ nafs aš-šay' 158

mänā qä'imfín-nats $187,188^{58}$

nq.s: $\quad$ nāqis 22,69

qaul nāqis 34

nql: $\quad$ naqil 97

naql 25,98

- ad-diwān $4^{17}$

nhy: nahy 62,147

nwn: tanwin 64

nwy: nıyya $16,190^{70}$ hy'wl" : ashāb al-hayūlā 132

"aql hayüläni 36

uğb : mànà müğib 188, 189

u'ğd: mauğùd hi-wuğūdlhi 134

ugh . wağh $62^{53}$

wuğüh 79

w'zn: ilm al-mizān $18^{81}$

u'sı: wāsıta 51,52

ws': แIısä* 73

u'sm: hasm 176

sima $134^{31}, 175,176,176^{73}$

mausūm $176^{73}$

wsf: wasf $49^{84}$

sifo $47,48^{79}, 49,49^{84}, 50,71$, $74^{22}$

- garr maușüf 71

mausüf $71,74^{22}$

ġair mausūf 71

wsl. sila $46,52^{102}, 53^{111}$

wàsila $46^{66}, 51,52$

n'dh: idāh al-wädihäl 159

$w d^{\prime}$ wada'a 'alā $140^{67}$

wudita alā 29, 174'1

nad $139,140,174,174^{61}$

-al-luga $\quad 174^{61}$

-- an-nahw 5

awwal al-wad 29

maudī" 74, 139

maudi $14,16,20^{7}$

muwādàa $174^{61}, 175$

w't' tawātu' $139^{64}$

wfq: itlufáq 139

$w q^{\prime}: \quad w a \bar{q} i^{\circ} \quad 83^{75}$

wkd. laukid 85

w'w: wāw 19, 20, 21, 22

$y^{\prime \prime} . \quad y \bar{a}^{\prime} \quad 19,20,21,22,51$

\section{GREEK TERMS}

abraám 65

adiápıồtos $62^{31}$

agoreuómenos 73

agrámmatos $31^{77}$

akinètos 24

ákliton $65,65^{71}$

ametábatos

rhèma - on $82^{73}$

analogia 93

analogismós

quyās - $101^{52}$

angeion 8 anômalia 181

ánthrôpos 40, 41, 55, 56

antônumia 50,51

aóristos 139

onoma - on $139^{62}$

aparémphatos 87

apathès 2647

aphairesis 26

áphôna 21

apódosis

hè toû idiou - 130

apophantıkón $146^{113}$ 
apóphasts 145

haı en tèl phônèt

katáphaseıs kaì —ets 184

apotelein 143

áptôton $63^{55}, 65$

archè $87^{106}$

arete

-aı kai kakiar tès léxeôs 16

artâsthat 70

árthron $46^{66}, 50,52$

ásèmos

phônè - 43

asômaton $60^{43}, 75$

autopsia 92, 96

autotélera 36

autotelès $34,35,37,144,146$

axiôma $72,72^{12}$

badizem 42

blituri $30,32,34,121^{3 \mathrm{~B}}$

brekekéx 31

charaktèr

- toû stotcheiou 46

chrôma $137^{45}$

chrónos 75

platukoss - $77^{36}$

dasís $22^{21}$

deloumenon $185^{44}$

deuteros

-a thésts 168

diábasts 82

dıálektos 93

diálogos $179^{1 \mathrm{~B}}$

diástèma 75

drastolè 92,103, 104

diáthesıs

$$
\text { héxers kai -is } 9
$$

psuchike - 9,146

dihorizon 52

diogénès $40^{11}, 55$

dioklès $40^{11}$

diôn $40^{11}, 55^{10}, 182$

diorismós 104

dóxa 184

egô $165^{1 \text { t }}$

ei diphthongos 22

eidos $143,144,187$

¿̇ toú lógou $147^{121}$

ekeinos $165^{18}$

ellipès 34,73

emperria $92,94,94^{20}, 97$

enallagè 26

endiathests $37^{114}$ endiáthetos

- lógos $179^{18}$

enérgera $71^{4}, 72^{10}, 141$

energón $72^{10}$

energoimenos $72^{10}$

engrámmatos 31

enthestôs $77^{36}, 80$

enklmómenos 68

énklisis 146

énnora $180^{18}$

entelécheıa $24^{20}$

epiktètos $36^{110}$

epulogismós

qiyās - $101^{32}$

epimerismós 22

epitheton 48

epsilón $22^{21}$

erôtèmatıkón $146^{113}$

èta 22

éthos $164^{13}$

étuma 165

etumología 93

euchrèstos

télos -on 130

euknkón $146^{113}$

eutheia 67

éxô

- lógos 179

genikds

一è (ptôsis) 69

in ónoma $88^{111}$

-in rhèma 88

génos 143,144

grámma $31^{77}$

gráphein 42, $42^{31}$

hègemonikón

$$
\text { pôs échon - } 184^{38}
$$

hellènismós $61,63,64,130$

kanónes -ồ 90

téchnal perì-oû 122

hellènizein 61

hèméra 30

hèmiphôna 21

héxis

eıs kà diathéseis 9

hippos $40,41,55,56$

historia $92,93,98$

hóros $62^{49}$

hugıainem $41^{27}, 42$

hugiès $26^{47}$

hülè $87^{106}$

hupárchein 75 
huphestanat $75,184^{37}$

hupographe 130

hupokeimenon 74

idıos $55^{11}$

-a poiótès $55^{7}$

hè toù -ou apódosts 130

Iòta 22

kakia

aretai kai -al tès léreós 16

kallias 55

kanôn 62,63

-es hellènismoú 90

-es onomankoi kai rhèmatıkoi 84

- es orthographias 93

katáphasss

hat en tèı phônèl -eis kai apóphase's 184

katègórèma 72,73

katègoria

onomatıkaî -aı tôn pragmátön 87

katégorıkós

onómata $\rightarrow \dot{a} 49$

katègoroúmenon 74, 82

katholikos $62^{49}$

kenón 75

kıneisthat 24

kinèsts 23, 24

—oû kósmou 75

klètıkón $146^{113}$

klisis $62^{53}, 64,65,65^{71}, 66,67$

koi 31

koinós $55^{11}$

¿̀ poiótès $55^{7}$

kremästhaı 70

ktètıkos

-è (ptôsıs) 69

légem $42^{31}, 186$

legómenon $183^{31}$

lektón 55, $55^{10}, 75^{26}, 146^{16}, 148,180^{20}$,

$181,182,183,184,185,186,187,188$,

189, 190

- autotelés 34, 146

- ellipés 34, 73

léxts $16,26,34,36,138,183^{31}$

- sèmantıkè $183^{33}$

limós 27

lithos 40

logıkós

- phantasia $182^{26}$

lógos $34,36,105,138,174^{59}, 179^{18}, 187$

—en tès psuchès 179

- ho tò ti èn einar sèmainôn 139

eidè $\mathrm{oû}$ - ou $147^{121}$

endiáthetos - $179^{18}$

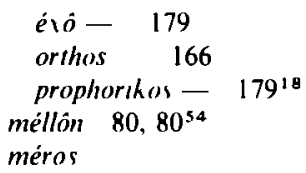

$\dot{e} \backslash \hat{o}-179$

orthos 166

prophorikos - $179^{18}$

méllôn $80,80^{54}$

méros

-c loû lógou 47

mesótés 52

metahalikós 83

metáhasıs 82,83

- เoû homoiou $92,96,97^{32}$

katà in tina $184^{37}$

rhèma on $\longrightarrow$ i $82^{73}$

metabole $27^{52}$

metáthesis 26

he tôn onomátôn $-13^{32}$

mikrós 22

monóptôton $63^{55}, 65,65^{71}$

nóèma $180^{20}, 183^{29}, 184,187$

noètón $133^{31}$

nómos $164^{13}, 167,174^{62}$

noûs

ho thirathen - 36

ô 52

ô méga 22

o mikrón 22

ónoma $38,55,60^{41}, 61^{45}, 142,143,185$

-a katègoriká 49

- toû prágmatos $82,83,87$

- toû rhematos 83

genikon $88^{111}$

hè tôn -ôn metáthesis $134^{32}$

onomazómenon 185

órganon $174^{59}$

orthós $16^{70}, 68,80^{58}$

- lógos 166

è piôsis 67

orthótès 173

ousia $56,60^{43}, 142$

pandéktès $8^{40}$

parágein 67

parágôga 168

paragôgé 65

paraschèmatısmós 48

paratèrèsis $93^{18}$

parelèluthôs 78, 80

parhepómena $62^{53}$

parhuphistámenon $183^{29}$

páthos $71^{4}, 141$

¿̇̀ tès léxeôs 26

—è tès phônès 26

patrikós

—ं (ptôsts) 69

phantasia $182^{26}, 184^{38}$ 
phantasthén $182^{26}$

phônè $26^{44}, 180^{18}, 183^{31}, 184^{38}, 185$

- ásèmos 43

- sèmanıkè $183^{33}$

páathè tès —ès 26

próıai-ai 165,167

tà en tèt èi 184

phônèenta 21

phônèukôn $182^{26}$

phúsis 163, 164, 165, 166, 167, 168, 169, $170,171,172,173,174$

plágıs

—aı ptôsets 69

platukós

- os chrónos $77^{36}$

pleonasmós $27^{52}$

polein 42

potótès 56

idia - $55^{7}$

koine $-55^{7}$

polú

epi $1 \dot{o}-94^{20}$

pôs échon 9

prâgma $71^{4}, 141,180^{18}, 182,183,183^{31}$, $184^{38}, 186,187,188,189$

- suntaktón 72

ónoma tô̂ - ros 82,87

praktikós 105

prophorikós 105

- lógos $179^{18}$

prosegoria 55

prósôpon $62^{53}$

prossèmainem 140, 141

prostakiikón $146^{113}$

prósthesis 26

prótasis 72

próteros $137^{42}$

prôtos

—al phônai 165, 167

- thésis 168

prôtótupa 168

pseudes 181

pseûdos 181

psilós 22, $22^{21}$

psuchè

lógos en tèt -èi 179

psuchikós

-al diathéseis 146

ptôsis $65^{71}, 66,68,72,73$

orthe - 67, 68, 69

plagiai -eis 69

puthmèn

es lógıôn 145 rhèma $38,60^{41}, 61^{45}, 142,143$

théma-los 81

genikón - 88

ónoma toù - los 83

rhiza 87,88

sèmainómenon $179,180^{18}, 182,185,189$

sèmainon $179,182,185$

sèmanukós 30

lêxts $-\dot{e} \quad 183^{33}$

phônè -

sèmeion $133^{31}, 182^{26}$

sókrátès 55,56

soloıkısmós $39^{10}$

sôma $26^{44}, 60^{43}, 137^{45}, 186$

stichos 46

stoubè 53

stoicheion $46,47,47^{76}, 48,138$

- toú lógou 47

sumbállein $101^{51}$

sumbebèkós 142

sumparhepómena $71^{4}, 142$

sumpáthera 79

sumphônia 92, 96

sunanhairein $143,144^{100}$

súndesmos $38,38^{6}, 43,44^{49}, 46,53$

- prothetikós 53

suneisphérein $143,144^{99}$

sunkatègorèmata $52^{107}$

sunkopè $27^{52}$

sunnoein 143

suntaktós 72,73

prâgma ón 72

suntaxis $23^{28}$

sunthèkè $164^{13}, 173,174$,

èi $174^{60}$

katà èn 138, $174^{60}$

sunthetós $138^{52}$

suntomia 129

súntomos 129

téchnè $16,92,128,130$

- peri hellènismoû 62,122

theôrètikè - 105

telein 37

téletos $36^{104}, 37$

teleiótès $24^{20}$

télos $24^{28}, 37$

- eúchrèston 130

théma

- rhèmatos 81

theôrein 105

theôrètikós 105

¿̀ téchnè 105

thésts $140,163,164,165,166,167,168$, $169,170,171,172,173,174$ 
deutéra - 168

prôtè - 168

thürathen

ho-noûs 36

II $135^{35}$

lógos ho to ti èn einat sèmainôn 129

tithenai

-katá $140^{67}$ tópos $75^{26}$

tropé $27^{52}$

trúphôn $40^{11}$

tunchänon $55,180^{20}, 182,182^{26}, 184^{38}$, $187,187^{\text {s }}$

tuptein 42

\section{LATIN TERMS}

adiectio $27^{48}, 165^{19}$

aequum et bonum $93^{19}$

analogia $93^{13}, 93^{14}$

ars $106,165,167,169,172,173^{56}$

auciorilas $93^{13}, 93^{14}$

colncidentia oppostlorum $159^{61}$

composifum 168

consigmificare $145^{106}$

consuetudo $93^{13}, 93^{14}, 93^{19}$

contrarium $166^{19}$

cunabulum

-a verborum $165^{17}$

declinatio

- naturals $169^{41}$

- voluntaria $169^{41}$

determinalıo 104

detractio $27^{48}, 165^{19}$

dicibile 183

discrimen

universa -ina $62^{49}$

dissimilis $181^{23}$

distinctio 104

equus $\mathbf{4 0}$

etymologia $93^{14}$

fulmentum $53^{109}$

homo $40,168,170$

Immutatio $27^{48}, 165^{19}$

intentio 171

—es universales 189

prima - $171^{49}$

secunda - $171^{49}$

iudicatum $93^{19}$

latinitas $62^{50}, 130$

lex $93^{19}, 167$

littera $32^{77}$

modus

- essendi $171^{\text {so }}$

- intelligendi $171^{\text {so }}$
- significandi $171^{\text {so }}$
mos $93^{19}$

natura $93^{19}, 106,165,167,168^{30}, 169$, $172,173^{56}$

naturahs

declinatıo - $169^{41}$

necessifas $25^{42}, 93^{19}$

nomen 170

nos $165^{18}$

observalio $93^{18}$

oratıo $179^{18}$

origo $166^{20}, 169^{38}$

pactum $93^{19}$

positıo

prima - 168

secunda 168

praesens 76

primus

-a intentio $171^{49}$

-a positio 168

propago $169^{38}$

quid $135^{35}$

ratlo $93^{14}, 93^{19}, 167,179^{18}$

res 183

secundus

-a intentıo $171^{49}$

a positio 168

similss $181^{23}$

similitudo $166^{19}$

stirps $165^{17}$

suppositio $171^{45}$

transitio 82

transmutatıo $27^{48}, 165^{19}$

universalis

intentiones -es 189

universus

-a discrimina $62^{49}$

usus $165,167,173^{56}$ 
verbum $170,183,183^{33}$

velustas $93^{14}$

vicintlas $166^{19}$

virtutes $16^{70}$

\author{
vitia $16^{70}$ \\ voluntarius \\ declinaıo $-a 169^{41}$ \\ vos $165^{1 \mathrm{~B}}$
}

\title{
HEBREW AND SYRIAC TERMS
}

\author{
'ätid 80 \\ hiqqiš 101 \\ h̆lāp̃ šmã 51 \\ hlima 26 \\ hölèf 80 \\ huššabāãã 51 \\ krihō 26 \\ mettezīānūtāa 24 \\ mutabbèr 82 \\ mšanyānā 82 \\ parsūpā $62^{53}$
}

\author{
pı̄āhā $6^{28}$ \\ šurrāyā 74 \\ tebbã 74 \\ ustuqsā 46 \\ ustuqyā 46 \\ zemān 'ōmēd 80 \\ zau'ā 24 \\ zavnā da-'bar 80 \\ zavnā da-'iịd 80 \\ zavnä de-damyã 79 \\ zavnā de-qä'em 80
}


The author was born in Arnhem on October 17th, 1947. After attending grammar school, where he passed the final examination in 1964, he studied Classical Languages at the University of Nijmegen, specializing in general linguistics, with Greek and Latin as subsidiary subjects. This study was concluded in 1969 with a doctoral examination. Besides he studied Semitic Languages, specializing in Arabic, with Hebrew as a subsidiary subject. This study was concluded in 1971 with a doctoral examination cum laude.

From 1969 to 1976 he taught Classical Languages at the Stedelijk Gymnasium in Arnhem.

In 1973 he was appointed at the University of Nijmegen to teach Arabic. In 1975 he became a staff member of the Institute for Languages and Cultures of the Middle East in Nijmegen. 


\section{STELLINGEN}

Bij het bestuderen van ontleningen binnen een corpus van grammaticale teksten is een vergelijkend onderzoek naar de gebruikte voorbeelden van het grootste belang; het is dan ook te betreuren, dat de index op Sibawaihi van Troupeau de paradigmata niet opgenomen heeft.

\section{II}

De woorden maudii, mauqi', manzila, mahall, magäm vormen binnen de Arabische grammaticale litteratuur een terminologisch complex; aangezien deze terminologie karakteristiek is voor de Arabische grammatica, is een nadere bestudering ervan gewenst.

\section{III}

Voor een bestudering van de $i^{i} r a ̈ b$ in de geschiedenis van de Arabische taal is het van belang rekening te houden niet alleen met het werkelijk gebruik, maar ook met de opvattingen over het wenselijk gebruik.

\section{IV}

Bij de bestudering van ontleningen aan het Grieks in de Arabische philosophische litteratuur kan men met veel vrucht kennis nemen van de methoden en resultaten van het onderzoek naar het Christelijk Latijn en Grieks.

\section{V}

Het vrijwel ontbreken van verwijzingen naar Griekse grammaticale werken in de Arabische litteratuur kan verklaard worden uit de speciale plaats die de Arabische taal inneemt in de Arabische wereld. 
Het tweede hoofdstuk van Zağğăği's "Idāh fi 'ilal an-nahww » is gebaseerd op Fārābī's commentaar op Porphyrios’ " Eisagôgè ".

\section{VII}

Ten onrechte gaat A. Denz bij zijn theoretische inleiding tot de aspectleer van het Arabische dialect van Kwairiš uit van zogenaamde noëtische categorieēn, waarbij tegenover het Zeichen de Sachverhalt geplaatst wordt.

(cfr. A. Denz, Die Verbalontax des neuarabischen Dialektes von Kwayriš (Irak). Mit einer einleitenden allgemeinen Tempusund Aspektlehre, Wiesbaden, 1971, p. 4, n. 4).

\section{VIII}

Nagel's opvattingen over de politiek van de 'Abbāsidische kalief al-Ma'mūn met betrekking tot de 'Aliden komen voort uit een te gunstige beoordeling van de motieven die het politieke handelen van deze kalief beheersten.

(cfr. T. Nagel, Rechtleitung und Kalifat. Versuch über eine Grundfrage der islamitischen Geschichte, Bonn, 1975, (Pp. 413-430).

IX

Het stilzwijgen van de Arabische bronnen ten aanzien van de gezantschappen, die door Karel de Grote naar Hārūn ar-Rašid gezonden zouden zijn, kan niet verklaard worden uit intolerantie van deze bronnen tegenover de Christenen, zoals door Musca gedaan wordt.

(cfr. G. Musca, Carlo Magno ed Harun al Rashid, Bari, 1963, pp. 43-44).

\section{$\mathbf{X}$}

De basis van het Stoïsch werkwoordelijk systeem wordt gevormd door de oppositie suntelikós/paratatikós. 
De gangbare opvattingen over Plato's « Ion " maken te weinig onderscheid tussen Sokrates' opmerkingen ad rem en zijn opmerkingen ad hominem; tengevolge hiervan krijgt men een karikaturaal beeld van de verhouding tussen Ion en Sokrates.

\section{XII}

Het is uiterst misleidend ten aanzien van de Stoīsche philosophie de term " metaphysica " te gebruiken.

(cfr. A. A. Long, in : A. A. Long (ed.), Problems in Sroicism, London, 1971, p. 75).

\section{XIII}

In een diglossie-situatie wordt de keuze voor de hogere of de lagere taalvariant niet bepaald door linguinstische factoren, maar door sociale en/of politieke factoren.

\section{XIV}

De rol van Kyrillos bij het ontstaan van een grammaticale terminologie voor de Slavische talen is nog nauwelijks onderzocht.

\section{XV}

Het ware wenselijk dat de Nederlandse communicatiemedia de termen Mohammedaan, Mohammedaans vervingen door Moslem (Muslim), Islamitisch.

\section{XVI}

Het volstrekt afwijzen door een groot aantal leraren van de voorstellen ter vernieuwing van het onderwijs die verkondigd worden in de discussienota "Contouren van een toekomstig onderwijsbestel" komt niet voort uit angst voor eigen positie of afkeer van vernieuwingen in het algemeen, maar uit een diepe en bijzonder serieus te nemen zorg voor het onderwijs.

Stellingen behorende bij het proefschrift van C. H. M. Versteegh. 


